\title{
ipen
}

AUTARQUIA ASSOCIADA À UNIVERSIDADE DE SÃO PAULO

\section{MÉTODOS PARA OBTENÇÃO DA ALTURA DA CAMADA LIMITE PLANETÁRIA A PARTIR DE DADOS DE LIDAR.}

\section{Gregori de Arruda Moreira}

Dr. Eduardo Landulfo

Dissertação apresentada como parte dos requisitos para obtenção do Grau de Mestre em Ciências na Área de Tecnologia Nuclear - Materiais

São Paulo - 2013 



\section{MÉTODOS PARA OBTENÇÃO DA ALTURA DA CAMADA LIMITE PLANETÁRIA A PARTIR DE DADOS DE LIDAR.}

Gregori de Arruda Moreira

Orientador: Eduardo Landulfo

São Paulo - 2013 

Dedico este trabalho a todos aqueles que sempre acreditaram em mim e me auxiliaram direta ou indiretamente. 

"Se eu pudesse eu dava um toque em meu destino Não seria um peregrino nesse imenso mundo cão E nem o bom menino que vendeu limão E trabalhou na feira pra comprar seu pão" (Guará/Fernandinho) 



\section{Agradecimentos}

Agradeço, primeiramente a Deus pelo apoio e constante inspiração para a realização deste trabalho. Ao professor e amigo Eduardo Landulfo, pela oportunidade de aprendizado e pela confiança em mim depositada. A minha família, principalmente aos meus pais, por todo o incentivo e o café da madrugada. A minha namorada Andreza pela compreensão. Aos amigos Eliana e Ronaldo pela confiança e liberação durante as horas de expediente na FEUSP. Aos companheiros do grupo de pesquisa (Fábio, Walter, Elaine, Riad, Renata, Patrícia, Daniel e Márcia) pelas dicas e conversas. Aos professores Amauri, Edson, Gerhard e Nadir pela colaboração nas campanhas. A FAPESP (Proc. 2011/50178-5), a FAPERJ e ao CNPQ (Proc. 476812/2011-9), pelo apoio financeiro. 



\section{Resumo}

Esta dissertação aborda um estudo sobre algoritmos matemáticos (Método da Variância, Método das Imagens, Método do Gradiente (MG), WCT - Wavelet Covariance Transform), os quais possibilitam a obtenção da altura máxima da Camada Limite Planetária (CLP) a partir de dados fornecidos por um sistema lidar. Em um primeiro momento será descrita a CLP e as suas principais variáveis, assim como também os métodos juntamente com os seus pontos positivos e negativos. Em seguida serão abordadas duas situações de medida: a primeira consiste em um estudo de casos realizado na cidade de Vitória-ES, para o qual foram escolhidas três situações típicas (calmaria, presença de subcamadas de aerossóis e/ou camadas de nuvens e turbulência) em que os métodos foram: testados, comparados entre si, com a análise visual do perfil e o BRN (Bulk Richardson's Number); a segunda situação aborda uma medida feita na cidade de São Paulo-SP durante um período de 12 horas contínuas, sendo o grande diferencial deste experimento, o lançamento de radiossondas dentro de intervalos de 3 horas, isso aliado a utilização de modelagem WRF (Weather Research Forecasting) permitiu uma maior comparação e validação dos dados.

A partir dos estudos de casos foi possível observar que com o aumento da complexidade do perfil apresentado pela atmosfera, há um decréscimo na qualidade dos resultados apresentados pelos métodos e um aumento no tempo de processamento, já que há necessidade de um maior refinamento nos parâmetros que serão utilizados.

Nas situações de "calmaria"o perfil da atmosfera se mostra mais simplificado, o que facilita a escolha de qual método utilizar, sendo que com exceção da Variância, todos 
os outros métodos forneceram resultados satisfatórios. Para o caso de "presença de subcamadas de aerossóis e/ou nuvens"a qualidade dos resultados apresentados pelos métodos decai sendo exceção da Variânci, uma vez que esta passa a apresentar resultados mais próximos do esperado devido ao aumento na complexidade do sinal lidar. Na situação caracterizada como "turbulência", todos os métodos passam a apresentar maiores dificuldades para detectar corretamente a CLP, sendo que o WCT se mostra o mais robusto, porém exige uma complexa escolha de parâmetros, demandando um alto tempo de processamento.

$\mathrm{Na}$ medida de 12 horas contínuas todos os métodos conseguem representar satisfatoriamente a ascensão e o decaimento da CLP, ficando as maiores divergências para o meio do dia, principalmente quando há dispersão dos aerossóis gerando atenuação no sinal, com isso os métodos mais sensíveis (MG e Método das Imagens) passam a apresentar várias oscilações, dificultando a detecção do topo da CLP.

As análises realizadas permitiram observar as vantagens e desvantagens de cada método, assim como descobrir qual possui o uso mais indicado para cada cenário meteorológico, sendo o algoritmo WCT o mais robusto em todas as situações apresentadas. 


\section{Abstract}

This dissertation discusses a study about mathematical algorithms (Variance Method, Method of Images, Gradient Method, WCT - Wavelet Covariance Transform) that allow obtaining the maximum height of the Planetary Boundary Layer (PBL) from data provided by the lidar system. Initially it will be described the PBL and their main variables, as well as methods along with their strengths and weaknesses. After, two situations of measurements will be discussed: the first one consists of a case study conducted in the city of Vitória-ES, where were chosen three typical situations ("calm", "sublayers of aerosols and/or layers of cloud cover"and "turbulence") and the methods were compared among themselves and here after validated qualitatively by a visual verify and quantitatively by obtain of the Bulk Richardson Number (BRN) extracted from radiosounding data; the second situation deals with a measurement made in the city of São Paulo - SP for a period of 12 continuous hours, and the great advantage of this experimen, launching radiosondes within 3 hour intervals, the use of this combined with WRF ( Weather Research Forecasting) model allowed a most accurate comparison and validation.

Based on case studies it was observed with the increased of complexity of the profile presented by the atmosphere, there is a decrease in the quality of the results provided by the methods and an increase in processing time being necessary greater refinement of the parameters that are used. In situations of "calm"the profile of the atmosphere appears more simplified, which facilitates the choice of which method to use, and with exception of Variance, all other methods provided satisfactory results. For the situation of "presence of sublayers of aerosols and/or clouds"the quality of the results presented by the methods decays, with the exception of Variance, once this 
begins to show results closer than expected due to the increase in the complexity of the signal handling. In situations characterized as "turbulence", all methods have more difficulties to correctly detect the PBL, and the WCT shown the most robust than others, but requires a complex choice of parameters and a high processing time.

The measurement of 12 hours continuous all methods can satisfactorily represent the rise and decay of PBL, the largest differences being for the middle of the day, especially when there is dispersion of aerosol generating attenuation in the signal, thus the most sensitive methods (Gradient Method and Method of Images) present several variations, making it difficult to detect the top of the PBL.

The analyzes allowed to observe the advantages and disadvantages of each method, as well as find out which has the most appropriate use for each meteorological scenario, being the WCT the most robust algorithm in all situations presented. 


\title{
Lista de Abreviaturas 1
}

\author{
AL Atmosfera Livre \\ $\mathrm{Cl} \quad$ Camada de Inversão \\ CLE Camada Limite Estável \\ CM Camada de Mistura \\ CLN Camada Limite Noturna \\ CLP Camada Limite Planetária \\ CLS Camada Limite Superficial \\ CLU Camada Limite Urbana \\ CR Camada Residual \\ CWT Continuous Wavelet Transform \\ DWT Discret Wavelet Transform \\ IPCC Intergovernamental Panel Climate Change \\ IPEN Instituto de Pesquisas Energéticas e Nucleares \\ LIDAR Llght Detection And Ranging \\ MCITY Mega City Brazil Project \\ PMT Fotomultiplicadora - (PhotoMulTiplier) \\ RCS Range Corrected Signal \\ SODAR SOnic Detection And Ranging \\ STFT Short Time Fourier Transform \\ WCT Wavelet Covariance Transform \\ WRF Weather Research and Forecasting Model \\ ZE Zona de Entranhamento
}





\section{Lista de Símbolos}

\begin{tabular}{ll}
$\beta$ & Coeficiente de Retroespalhamento \\
$c$ & Velocidade da Luz \\
$F^{*}$ & Saldo Líquido de Radiação para o Fluxo de Superfície \\
$F_{B G R}$ & Radiação de Fundo \\
$F_{B S C}$ & Radiação Retroespalhada \\
$F_{E l a s t, S i n g}$ & Radiação que sofre apenas um Espalhamento Eslástico \\
$F_{E l a s, M u l t}$ & Radiação que sofre Múltiplos Espalhamentos Elásticos \\
$F_{E s}$ & Fluxo de Calor Latente \\
$F_{G s}$ & Condução de Calor no Solo \\
$F_{H s}$ & Fluxo de Calor Sensível \\
$F_{I n e l a s}$ & Radiação que sofre Espalhamento Inelástico \\
$F_{T o t}$ & Fluxo Total de Radiação \\
$g$ & Aceleração da Gravidade \\
$L$ & Calor Latente \\
$L_{\uparrow}$ & Fluxo de Saída de Radiação de Ondas Longas \\
$q$ & Umidade Relativa \\
$R_{b s}$ & "Bulk"Número de Richardson \\
$R_{s}$ & Número de Richardson Crítico \\
$\sigma$ & Coeficiente de Extinção \\
$T$ & Temperatura Potencial \\
$\tau$ & Tempo de duração do pulso do Laser \\
$\theta_{v}$ & Sinal lidar \\
$V$ & Temperatura Potencial \\
\hline & Velocidade do Vento \\
\hline &
\end{tabular}




\section{Lista de Figuras}

3.1 Perfil vertical da parte baixa da Atmosfera - Adaptado de [53] . . . . . . . 8

3.2 Variação da CLP de acordo com os diferentes regimes de pressão. $A$

linha pontilhada indica a altura máxima alcançada pelo ar da superfície modificado durante o período de uma hora. A linha sólida demarca a região mais estudada- Adaptado de [45]]. . . . . . . . . . . . . . . . . . 9

3.3 (a) Período Diurno (Fluxo Positivo) - (b) Período Noturno (Fluxo Negativo) [53] . . . . . . . . . . . . . . . . . . . . . . . . . . . . . . . . . . 10

3.4 Perfil da Temperatura Potencial Virtual ao longo da CLE e a Estabilidade Atmosférica [45] . . . . . . . . . . . . . . . . . . . . . . . . . . . . . . . . 12

3.5 Perfil da Temperatura Potencial Virtual na CLN e a Estabilidade Atmosférica [45] . . . . . . . . . . . . . . . . . . . . . . . . . . . . . . . 14

3.6 Perfil da Temperatura Potencial Virtual na CLC e a Estabilidade Atmosférica [45] . . . . . . . . . . . . . . . . . . . . . . . . . . . . . . 15

3.7 Evolução temporal da CLP - Adaptado de [45] . . . . . . . . . . . . . . . 16

3.8 Perfil das variáveis de estado - Adaptado de [53] . . . . . . . . . . . . . . 18

3.9 Evolução da CLP de acordo com as mudanças de temperatura potencial - Adaptado de [45] . . . . . . . . . . . . . . . . . . . . . . . . . . . . . 19

3.10 Variação na temperatura do Ar desde uma região Rural até o Centro da Cidade. Adaptado de [33] . . . . . . . . . . . . . . . . . . . . . . . . . . 20

3.11 Perfil da temperatura potencial desde a região rural até o centro da cidade. Adaptado de [2]] . . . . . . . . . . . . . . . . . . . . . . . . . . . 22

3.12 Representação de um Sistema Lidar (1 - Transmissor; 2 - Receptor; $3,4,5$ - Detector [27] . . . . . . . . . . . . . . . . . . . . . . 24 
3.13 Principais tipos de Telescópios utilizados pelo sistema LIDAR [26]. . . . 25

3.14 a - Sistema lidar Coaxial, b - Sistema lidar Biaxial . . . . . . . . . . 26

3.15 Perfil do sinal lidar . . . . . . . . . . . . . . . . . . . . . . 28

3.16 A - Perfil lidar idealizado. B - Perfil lidar real . . . . . . . . . . . . 31

4.1 Sistema lidar Móvell . . . . . . . . . . . . . . . . . . . . . . . . . . . 34

$4.2 O(A)$ Sinal lidar bruto sofrerá correções torando-se RCS. Os perfis serão unidos e darão origem ao (B) gráfico cortina. . . . . . . . . . . . . 35

4.3 Perfil Vertical da Atmosfera gerado a partir de dados captados por um sistema lidar . . . . . . . . . . . . . . . . . . . . 36

4.4 Perfil Vertical da Atmosfera . . . . . . . . . . . . . . . . . . . . . 37

4.5 Comparação entre o BRN e o Método das Parcelas . . . . . . . . . . 39

4.6 Comparação entre o perfil da Derivada Simples (Esq.) e o da Derivada

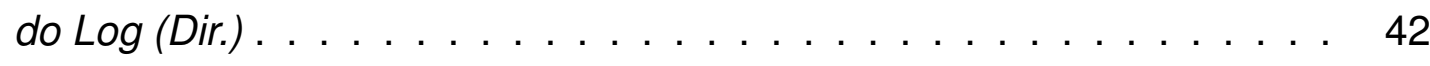

4.7 Comparação entre a Função de Haar e o Perfil Lidar Idealizado. . . . . . 44

4.8 Perfil da WCT com variações no Parâmetro a . . . . . . . . . . . . . . 45

4.9 Comparação entre as imagens antes e depois da aplicação do filtro . . 46

4.10 Gráfico cortina gerado pelo LabView a partir de dados lidar. . . . . . . 47

4.11 Figura antes da aplicação do filtro de Solarização (Esq.) e após a aplicação do mesmo (Dir.) . . . . . . . . . . . . . . . . . . . . . . 48

4.12 Imagem após a aplicação do Filtro Edge Detect $\ldots . . . . . . . . .49$

4.13 Imagem após aplicação do Filtro de Canny . . . . . . . . . . . . . 50

4.14 Resultado do Método das Imagens . . . . . . . . . . . . . . 50

$5.1 \quad$ Perfil lidar para um dia de Calmaria . . . . . . . . . . . . . . . . 52

5.2 Método da Variância . . . . . . . . . . . . . . . . . . 53

5.3 Comparação entre o Método da Variância e o BRN . . . . . . . . . . . 54

5.4 Método das Imagens. . . . . . . . . . . . . . . . . . . 55

5.5 Comparação entre o Método das Imagens e o BRN . . . . . . . . . 56

5.6 Perfil Individual obtido a partir do Método do Gradiente . . . . . . . . . 57

5.7 Método do Gradiente com variação de Limiar . . . . . . . . . . . . 58 
5.8 Método do Gradiente. . . . . . . . . . . . . . . . . . . . . . . . 58

5.9 Comparação entre o Método do Gradiente e o BRN . . . . . . . . . . . 59

5.10 Perfil Individual obtido a partir do Método WCT . . . . . . . . . . 60

5.11 Método WCT com variação de limiar . . . . . . . . . . . . . . . 61

5.12 Método WCT com variação de "b" . . . . . . . . . . . . . . . . . 62

5.13 Método WCT com variação de "a" . . . . . . . . . . . . . . . . 62

5.14 Método da WCT . . . . . . . . . . . . . . . . . . . . 63

5.15 Comparação entre o Método WCT e o BRN . . . . . . . . . . . . 63

5.16 Comparação entre os métodos . . . . . . . . . . . . . . . 64

5.17 Perfil lidar para um dia com pequena concentração de Nuvens . . . . . 65

5.18 Método da Variância . . . . . . . . . . . . . . . . . . . . . 66

5.19 Comparação entre o Método da Variância e o BRN . . . . . . . . . . 67

5.20 Método das Imagens. . . . . . . . . . . . . . . . . . 68

5.21 Comparação entre o Método das Imagens e o BRN . . . . . . . . . 69

5.22 Perfil Individual obtido a partir do Método do Gradiente . . . . . . . . 70

5.23 Método do Gradiente com variação de Limiar . . . . . . . . . . . . 71

5.24 Método do Gradiente. . . . . . . . . . . . . . . . . . . . . . . 72

5.25 Comparação entre o Método do Gradiente e o BRN . . . . . . . . . . 72

5.26 Perfil Individual obtido a partir do Método WCT . . . . . . . . . . 73

5.27 Método WCT com variação de "a" . . . . . . . . . . . . . . . 74

5.28 Método WCT com variação de "b" . . . . . . . . . . . . . . . . 75

5.29 Método WCT com variação de limiar . . . . . . . . . . . . . . . 75

5.30 Método da WCT . . . . . . . . . . . . . . . . . . . . . 76

5.31 Comparação entre o Método WCT e o BRN . . . . . . . . . . 76

5.32 Comparação entre os métodos . . . . . . . . . . . . . . . 78

5.33 Perfil lidar para um dia de Turbulência . . . . . . . . . . . . . . . 79

5.34 Método da Variância . . . . . . . . . . . . . . . . . . . . . . 80

5.35 Comparação entre o Método da Variância e o BRN . . . . . . . . . . . . 81

5.36 Método das Imagens. . . . . . . . . . . . . . . . . . . . 82

5.37 Comparação entre o Método das Imagens e o BRN . . . . . . . . 83 
5.38 Perfil Individual obtido a partir do Método do Gradiente . . . . . . . . 84

5.39 Método do Gradiente com variação de Limiar . . . . . . . . . . . . . 85

5.40 Método do Gradiente. . . . . . . . . . . . . . . . . . . . . . . . 85

5.41 Comparação entre o Método do Gradiente e o BRN . . . . . . . . . 86

5.42 Perfil Individual obtido a partir do Método WCT . . . . . . . . . . . . . 87

5.43 Método WCT com variação de "a" . . . . . . . . . . . . . . . . 88

5.44 Método WCT com variação de "b" . . . . . . . . . . . . . . . . . 89

5.45 Método WCT com variação de limiar . . . . . . . . . . . . . . . . 89

5.46 Método da WCT . . . . . . . . . . . . . . . . . . . . . . . . 90

5.47 Comparação entre o Método WCT e o BRN . . . . . . . . . . . . . . 90

5.48 Comparação entre os métodos . . . . . . . . . . . . . . . . 91

5.49 Perfil lidar para um medida de 12 Horas . . . . . . . . . . . . . 93

5.50 Método da Variância . . . . . . . . . . . . . . . . . . . . . . . . . 95

5.51 Comparação entre o Método da Variância e o BRN. . . . . . . . . . . 95

5.52 Método das Imagens. . . . . . . . . . . . . . . . . . . . . 97

5.53 Comparação entre o Método das Imagens e o BRN . . . . . . . . . 97

5.54 Método do Gradiente. . . . . . . . . . . . . . . . . . . . . . . . 99

5.55 Comparação entre o Método do Gradiente e o BRN . . . . . . . . . . 99

5.56 Método WCT . . . . . . . . . . . . . . . . . . . . . . . . 101

5.57 Comparação entre o Método WCT e o BRN . . . . . . . . . . . . 101

5.58 WRF . . . . . . . . . . . . . . . . . . . . . . . . . . 104

5.59 Comparação entre os métodos . . . . . . . . . . . . . . . 106

A.1 Sodar Monoestático . . . . . . . . . . . . . . . . . . . . . . . 114

A.2 Sodar Monoestático . . . . . . . . . . . . . . . . . . . 115

A.3 Diagrama de Pasquill-Gifford para o dia 25 de julho. . . . . . . . . . 116

A.4 Diagrama de Pasquill-Gifford para o dia 26 de julho. . . . . . . . . . 116

A.5 Diagrama de Pasquill-Gifford para o dia 28 de julho. . . . . . . . . . 117 


\section{Lista de Tabelas}

5.1 Parametros Temporais utilizados no WRF $\ldots \ldots \ldots \ldots \ldots$

5.2 Parâmetros Espaciais utilizados no WRF $\ldots \ldots \ldots \ldots \ldots$

6.1 Tempo de Processamento . . . . . . . . . . . . . . . . . . . . 108

6.2 Dificuldade para a escolha de Parâmetros . . . . . . . . . . . 108

6.3 Proximidade dos resultados com relação ao valor adotado como padrão 108

6.4 Situação de Calmaria . . . . . . . . . . . . . . . . . . . . . . 109

6.5 Situação de Presença de subcamadas de aerossóis e/ou camadas de nuvens. . . . . . . . . . . . . . . . . . . . . . . . . . . . . . 110

6.6 Situação de Turbulência . . . . . . . . . . . . . . . . . . . . 110

6.7 Situação de 12 Horas Contínuas . . . . . . . . . . . . . . . 111 


\section{Sumário}

\begin{tabular}{lll}
\hline & Introdução & 1
\end{tabular}

2 Objetivos 5

$\begin{array}{lll}3 & \text { Revisão Bibliográfica } & 7\end{array}$

3.1 Camada Limite Planetáia $\ldots \ldots \ldots$. . . . . . . . . . . . . . . . . . . . . . 7

3.1 .1 CLE - Camada Limite Estável . . . . . . . . . . . . . . . . . . . . . 11

3.1 .2 CLN - Camada Limite Neutra . . . . . . . . . . . . . . . . . . . . 13

3.1.3 CLC - Camada Limite Convectiva . . . . . . . . . . . . . . . . . . 14

3.1 .4 Ciclo da CLP $\ldots \ldots \ldots \ldots$

3.1 .5 CLU - Camada Limite Urbana . . . . . . . . . . . . . . . . . . . . 18

3.2 O sensoriamento Remoto . . . . . . . . . . . . . . . . . . . . . . . . . . . 22

3.2 .1 A técnica lidar . . . . . . . . . . . . . . . . . . 23

4 Metodologia 33

4.1 Coleta de Dados . . . . . . . . . . . . . . . . . . . . . . . . . 33

4.2 Instrumentação . . . . . . . . . . . . . . . . . . . . . . . . . . . . . 34

4.3 Algoritmos para Análise de Dados . . . . . . . . . . . . . . . . . . . . . 36

4.3 .1 Método Bulk Richardson Number (BRN) . . . . . . . . . . . . . . 38

4.3 .2 Método do Gradiente (MG) . . . . . . . . . . . . . . . . . . . . . 41

4.3.3 Método da Covariância da Transformada de Wavelet (WCT) . . . 43

4.3 .4 Método da Variância . . . . . . . . . . . . . . . . . . . . . 46

4.3 .5 Método das Imagens $\ldots \ldots$. . . . . . . . . . . . . . . . . . 47 
5 Resultados e Discussões 51

$5.1 \quad$ Estudo de Casos . . . . . . . . . . . . . . . . . . . . . . . . . 52

5.1 .1 Situação de 'Calmaria' . . . . . . . . . . . . . . . . . . 52

5.1 .2 Método da Variância aplicado a situação de 'Calmaria'. . . . . . 53

5.1 .3 Método das Imagens aplicado a situação de 'Calmaria' . . . . . 55

5.1 .4 Método do Gradiente aplicado a situação de 'Calmaria' . . . . . 57

5.1.5 Método Wavelet Covariance Transform aplicado a situação de 'Calmaria' . . . . . . . . . . . . . . . . . . . . . . . 60

5.1.6 Avaliação dos Métodos para a situação de 'Calmaria' . . . . . . 64

5.1.7 Situação de Presença de subcamadas de aerossóis e/ou camadas de nuvens $\ldots \ldots \ldots$

5.1.8 Método da Variancia aplicado a situação de Presença de subcamadas de aerossóis e/ou camadas de nuvens . . . . . . . 66

5.1.9 Método das Imagens aplicado a situação de Presença de subcamadas de aerossóis e/ou camadas de nuvens . . . . . . . 68

5.1.10 Método do Gradiente aplicado a situação de Presença de subcamadas de aerossóis e/ou camadas de nuvens . . . . . . . 70

5.1.11 Método Wavelet Covariance Transform aplicado a situação de Presença de subcamadas de aerossóis e/ou camadas de nuvens 73

5.1.12 Avaliação dos Métodos para a situação de Presença de subcamadas de aerossóis e/ou camadas de nuvens . . . . . . . 77

5.1 .13 Situação de 'Turbulência' . . . . . . . . . . . . . . . . . . 79

5.1.14 Método da Variância aplicado a situação de 'Turbulência'] . . . . 80

5.1.15 Método das Imagens aplicado a situação de 'Turbulência']. . . . 82

5.1.16 Método do Gradiente aplicado a situação de 'Turbulência' . . . 84

5.1.17 Método Wavelet Covariance Transform aplicado a situação de 'Turbulência' . . . . . . . . . . . . . . . . . . . . . . . . . . 87

5.1.18 Avaliação dos métodos para a situação de 'Turbulência' . . . . . 91

5.2 Medida de 12 horas contínuas $\ldots \ldots \ldots \ldots$. . . . . . . . 92 
5.2.1 Método da Variância aplicado a uma situação de 12 horas contínuas de medição . . . . . . . . . . . . . . . . . . . . . . . . 94

5.2.2 Método das Imagens aplicado a uma situação de 12 horas contínuas de medição . . . . . . . . . . . . . . . . . . . . 96

5.2.3 Método do Gradiente aplicado a uma situação de 12 horas contínuas de medição . . . . . . . . . . . . . . . . . . . . . . . . 98

5.2.4 Wavelet Covariance Transform aplicado a uma situação de 12 horas contínuas de medição . . . . . . . . . . . . . . . . 100

5.2 .5 Weather Research and Forecasting - WRF Model . . . . . . . . 102

5.2.6 Avaliação dos Métodos para uma situação de 12 horas contínuas de medição . . . . . . . . . . . . . . . . . . . . 105

\begin{tabular}{lll}
\hline & Conclusão & 107
\end{tabular}

\begin{tabular}{ll}
\hline A Sodar & 113
\end{tabular}

\begin{tabular}{ll}
\hline B Estatística & 119
\end{tabular}

B.1 Desvio Padrão . . . . . . . . . . . . . . . . . . . . . . . . . . . . . 119

B.2 Média Móvel . . . . . . . . . . . . . . . . . . . . . . . . . . . . . 119 


\section{Capítulo 1}

\section{Introdução}

Nos dois últimos séculos, o aumento da prática de atividades relacionadas a queima de combustíveis fósseis elevou os números da emissão antropogênica de poluentes atmosféricos e gases estufa, causando influências diretas na atmosfera e consequentemente no clima do planeta [25]. Segundo o IPCC ( Intergovernmental Panel on Climate Changes) a intensificação nas emissões antropogênicas tem ocasionado algumas alterações: na temperatura média do planeta, nos níveis de precipitação, no derretimento das geleiras e na qualidade do ar, afetando consequentemente a saúde e a forma de vida dos seres no planeta Terra [25]. No entanto, para compreender melhor essas alterações é necessário primeiramente entender melhor a atmosfera e seus principais fenômenos, como exemplo: a filtragem dos raios-ultravioletas pela camada de Ozônio; a realização do efeito estufa para a manutenção da temperatura média do planeta; etc [53].

É possível subdividir a atmosfera em diversas regiões, sendo que dentre estas umas das mais importantes é a troposfera. Tal região é habitada pelos seres vivos do planeta, logo é a que mais sofre as alterações citadas acima, pois está em contato direto com a superfície terrestre recebendo continuamente as emissões e armazenando os poluentes [53].

Na parte mais baixa da troposfera há uma região denominada Camada Limite Planetária (CLP), na qual ocorrem as principais trocas de energia entre a superfície terrestre e a atmosfera, a qual influencia os fenômenos de micro e mesoescala, 
afetando diretamente a vida na superfície terrestre. Esta camada também é reciprocamente afetada pelas diversas interações decorrentes dos fenômenos que ocorrem na superfície terrestre, principalmente pelas alterações nos fluxos de energia [2, 19, 20, 45, 53, 33].

Tais fatores mostram a grande importância do estudo da CLP [8, 11, 16, 17, 21. 28, 13, 39] principalmente em questões relacionadas ao conhecimento do valor de sua altura máxima e do seu comportamento ao longo do dia, pois tais informações possuem várias aplicações, como por exemplo:

- Controle e gerenciamento da qualidade do ar: tal estudo é associado ao transporte e dispersão de poluentes atmosféricos, processos estes que dependem da mistura turbulenta na CLP [19];

- Estudo de forçantes climáticas: nesta camada a concentração de aerossóis geralmente é superior a encontrada em outras regiões da atmosfera, e como estes afetam os processos de transferência radiativa, o conhecimento da altura máxima da CLP torna-se fundamental para o entendimento da influência dos mesmos [19, 48];

- Modelagem: diversos modelos possuem como parâmetro de entrada a altura máxima da CLP [19];

Para compreender tais processos é necessário descrever corretamente os fenômenos físicos e químicos envolvidos, a dinâmica e a evolução da altura da CLP ao longo do tempo. Portanto, é de fundamental importância a realização de observações experimentais nesta camada, principalmente por causa do efeito de aprisionamento dos aerossóis, vapor d'água e poluentes. Um estudo apurado desta região, irá possibilitar um melhor entendimento dos processos que a regulam, e consequentemente uma melhor compreensão dos impactos das emissões antropogênicas na atmosfera.

Um dos métodos mais convencionais para o estudo da CLP é através da utilização de Radiossondagens, as quais possibilitam a obtenção dos perfis de 
alguns parâmetros atmosféricos, como por exemplo: direção e velocidade do vento, temperatura potencial, umidade relativa, etc. A partir de tais informações é possível obter uma visão sobre o comportamento da atmosfera [34]. Porém como a maioria das estações realizam dois lançamentos diários, não é possível obter um acompanhamento da evolução da CLP ao longo do dia com uma alta resolução temporal.

Outra importante ferramenta para o estudo da CLP é a utilização de equipamentos de sensoriamento remoto. Os quais são atrativos por dois fatores principais [43]:

- Conseguem fornecer medidas onde as técnicas in-situ não conseguem ou são economicamente inviáveis [20];

- São capazes de fornecer medidas de variáveis importantes da atmosfera, com alta resolução espacial e temporal [20];

Dentre as diversas técnicas de sensoriamento remoto, uma das mais utilizadas nas últimas duas décadas tem sido o sistema lidar² [5, 7, 12, 31, 29, 22, 34](Light Detection And Ranging), dotado de grande sensibilidade e portanto, uma ferramenta capaz de fornecer o perfil vertical da atmosfera de forma detalhada [12].

A alta resolução espacial deste sistema aliada aos bons resultados apresentados [5, 4, 7, 10, 12, 31, 29, 22, 34, 44, 47], fizeram com que nos últimos anos o lidar se consolidasse como uma das principais ferramentas para a análise da CLP.

Esta dissertação está dividida em seis capítulos. O primeiro retrata uma introdução sobre a problemática a ser discutida. No segundo são explicitados os principais objetivos almejados quanto a execução desta pesquisa. O terceiro capítulo é faz uma revisão bibiliográfica sobre o lidar e a CLP, abordando a estrutura e determinados fenômenos que ocorrem na mesma. No quarto são apresentados os algoritmos que serão utilizados para a análise de dados, indicando os pontos positivos e negativos de cada um. O quinto capítulo aborda os resultados obtidos e a discussão sobre eles, sendo este dividido em duas partes: a primeira aborda um estudo de casos baseado em um campanha realizada em Vitória-ES, e a segunda é referente a uma medida de ${ }^{2} \mathrm{~A}$ sigla lidar, a exemplo de: radar e sodar, é atualmente utilizada como um substantivo próprio. 
12 horas contínuas, a qual foi realizada junto ao projeto MCITY. No sexto capítulo são apresentadas as conclusões a respeito da dissertação e expectativas para trabalhos futuros. 


\section{Capítulo 2}

\section{Objetivos}

O objetivo deste trabalho é a realização de um estudo comparativo entre quatro algoritmos matemáticos (Variância, Métodos das Imagens, Método do Gradiente e WCT), os quais possibilitam a obtenção da Altura da Camada Limite Planetária, a partir de dados coletados por um lidar. Mediante a análise de dados, espera-se detectar qual o método eficiente dependendo das diferentes situações meteorológicas expostas (baseadas em dados observacionais): "calmaria", "presença de subcamadas de aerossóis e/ou camadas de nuvens"e "turbulência". Estas metodologias também irão, num segundo momento, servir de critério para o estabelecimento de um procedimento automatizado de obtenção da CLP. Após a realização deste estudo também se espera adquirir maior conhecimento sobre o sistema lidar, tanto em quesitos de instrumentação, quanto na coleta e análise de dados. 


\section{Capítulo 3}

\section{Revisão Bibliográfica}

\subsection{Camada Limite Planetáia}

Segundo Garrat [19] a Camada Limite Planetária pode ser considerada como: "A região da troposfera que é diretamente influenciada pela superfície da Terra, e possui um tempo de resposta aos seus forçantes, de cerca de uma hora ou menos" Figura 3.1. Ou seja, tal camada é formada como consequência das interações entre a atmosfera e a superfície subjacente (terra ou água), e os principais agentes destas interações são: evaporação, transpiração, fluxos de calor, emissão de poluentes, chuvas, nuvens, etc. Ainda que indiretamente toda a troposfera possa mudar em resposta as características da superfície, este processo é relativamente lento fora da CLP [19].

As principais características desta camada são:

- Manter a "ligação" entre a superfície e a atmosfera, influenciando a transferência de calor e umidade entre elas [24];

- Ser fundamental na determinação das propriedades do ar que entra na base das nuvens e gera as condições necessárias para a convecção da umidade [24];

- Ter um papel central na determinação da ocorrência de nuvans baixas e os consequentes efeitos sobre os limites de radiação [24];

- Reter aerossóis e poluentes [24]; 


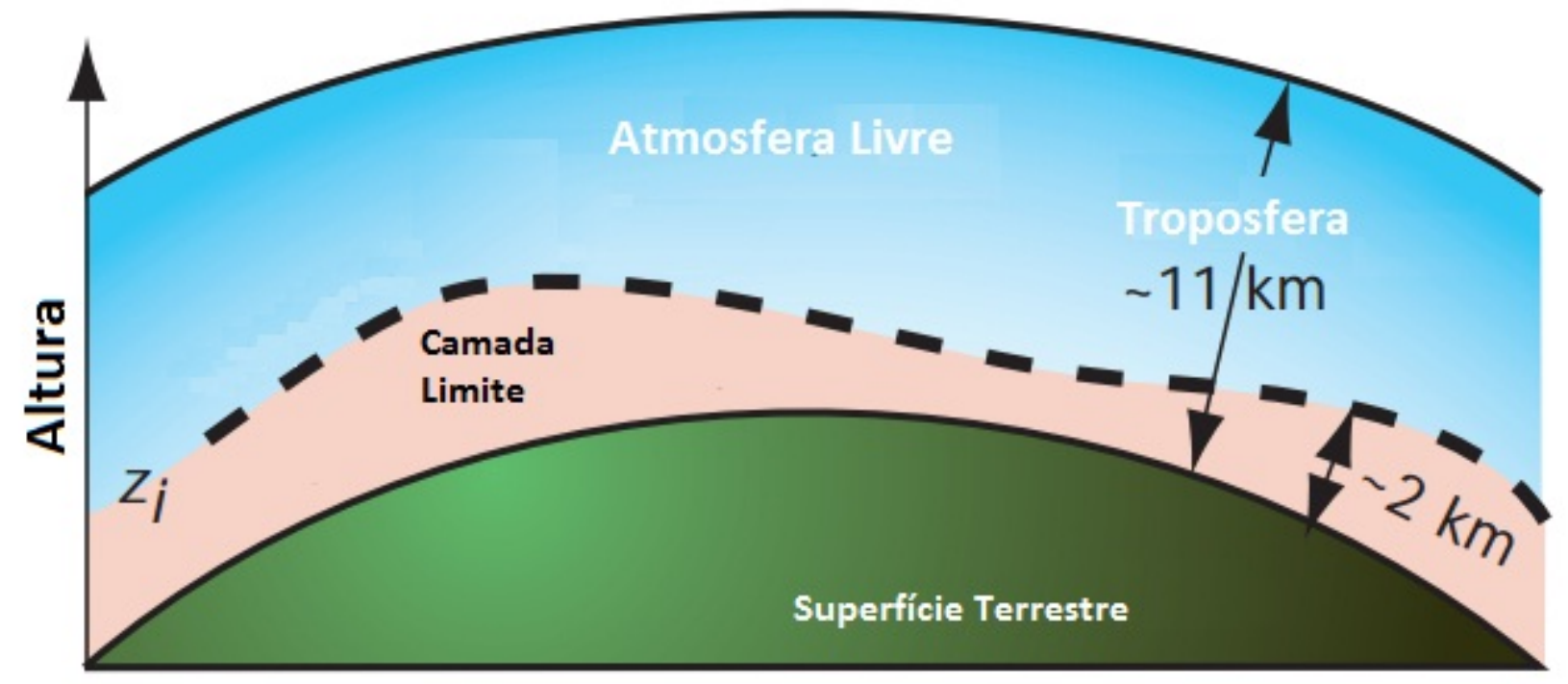

\section{Distância Horizontal}

Figura 3.1: Perfil vertical da parte baixa da Atmosfera - Adaptado de [53]

Uma parâmetro importante da CLP é o seu topo, o qual é definido como: o local onde o ar da CLP e o da troposfera livre são encontrados em igual proporção [5]. Tal altura é um parâmetro importante para a determinação de diversos processos que ocorrem na troposfera, como por exemplo: distribuição de aerossóis, atividade convectiva, formação de nuvens, determinação do volume avaliável para dispersão de poluentes, etc. Além de também atuar como dado de entrada para modelos atmosféricos.

As variações de altura na CLP vão de centenas de metros a alguns quilômetros (Fig. 3.1 $)^{3}$, dependendo das influências das forçantes citadas acima, as quais ocorrem através de mecanismos de transferência turbulenta [45]. Essas variações geralmente são caracterizadas por um ciclo sazonal no qual as máximas são encontradas durante os meses de verão, devido as mudanças de: temperatura da superfície, umidade específica, estabilidade e etc. As alternâncias nos valores da altura também estão relacionadas a ciclos diários (devido a mudanças no fluxo de calor) e a questões de latitude. [22].

Sobre os oceanos as variações de altura na CLP são mais lentas quando

\footnotetext{
${ }^{3} \mathrm{~A}$ altura indicada na figura para a troposfera é referente ao Hemisfério Norte, na faixa de latitude de São Paulo a altura da troposfera varia entre 15 e $16 \mathrm{Km}$.
} 
comparadas as que ocorrem na superfície terrestre. Como a capacidade calorífica da água é alta, ocorre pouca variação diurna na temperatura de superfície do mar, logo é reduzida a velocidade das trocas de calor entre superfície e atmosfera gerando variações na altura em cerca de apenas $10 \%$, diferentemente do que acontece no continente [2].

Tanto sobre o continente quanto sobre o oceano, a CLP possui a tendência de ser mais fina em regiões de alta pressão do que em regiões de baixa pressão. A subsidência do ar e o movimento divergente em baixos níveis retira a camada limite dos níveis mais altos para alturas menores.

Em regiões de baixa pressão, os movimentos ascendentes transportam o ar da CLP para longe do solo em grandes altitudes através da atmosfera, sendo difícil definir o topo da CLP para estas situações. A base das nuvens é frequentemente usada como indicador, embora um tanto arbitrário, para os estudos da CLP nestes casos. Em regiões de alta pressão, a CLP possui uma estrutura mais bem definida, principalmente sobre o continente (Fig. 3.2) [45].

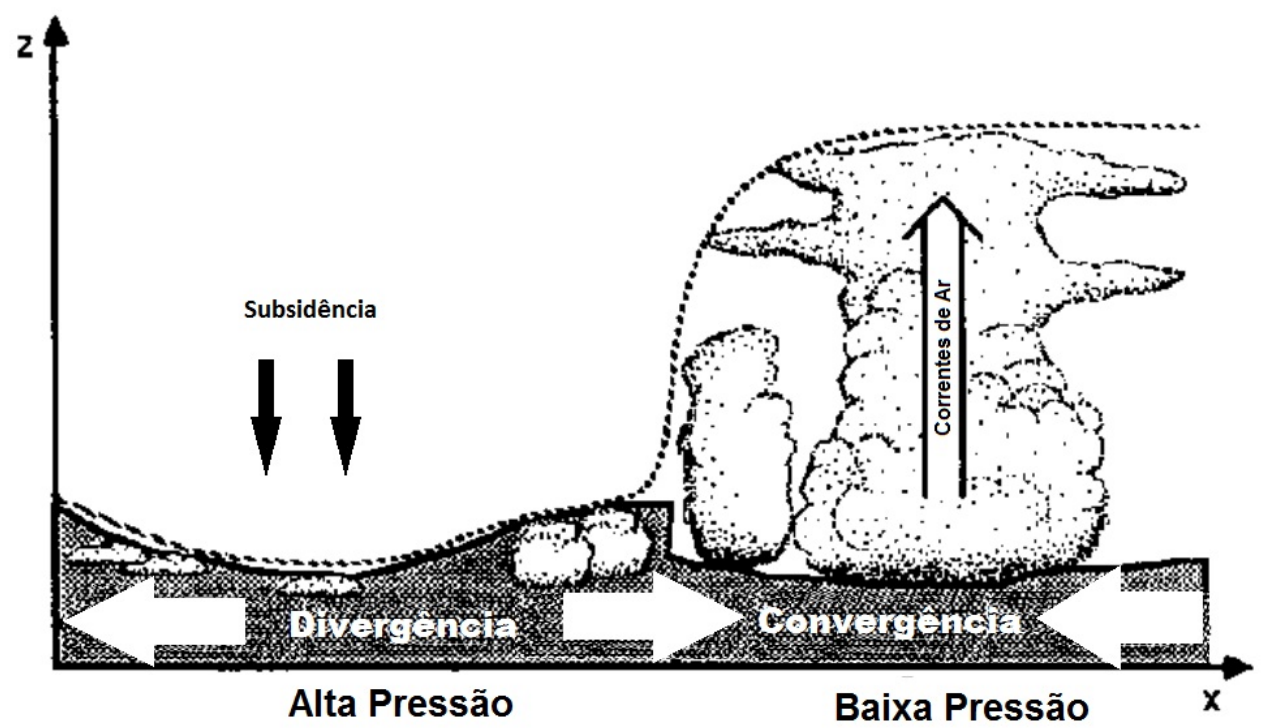

Figura 3.2: Variação da CLP de acordo com os diferentes regimes de pressão. A linha pontilhada indica a altura máxima alcançada pelo ar da superfície modificado durante o período de uma hora. A linha sólida demarca a região mais estudada- Adaptado de [45]

Quando a superfície do solo está mais aquecida do que a atmosfera, ela aquece a camada de ar imediatamente adjacente por condução e esta, por convecção, aquecerá 
a CLP por inteiro. Portanto pode-se afirmar que há um fluxo positivo de calor (Fig. 3.3 (a)). Porém, durante a noite, o solo passa a emitir radiação de onda longa, perdendo calor, passando então a receber calor da atmosfera. A partir de então, ocorre uma inversão no processo, ou seja, o solo atua como sumidouro de calor e o fluxo se torna negativo (Fig.3.3 (b) )[32].

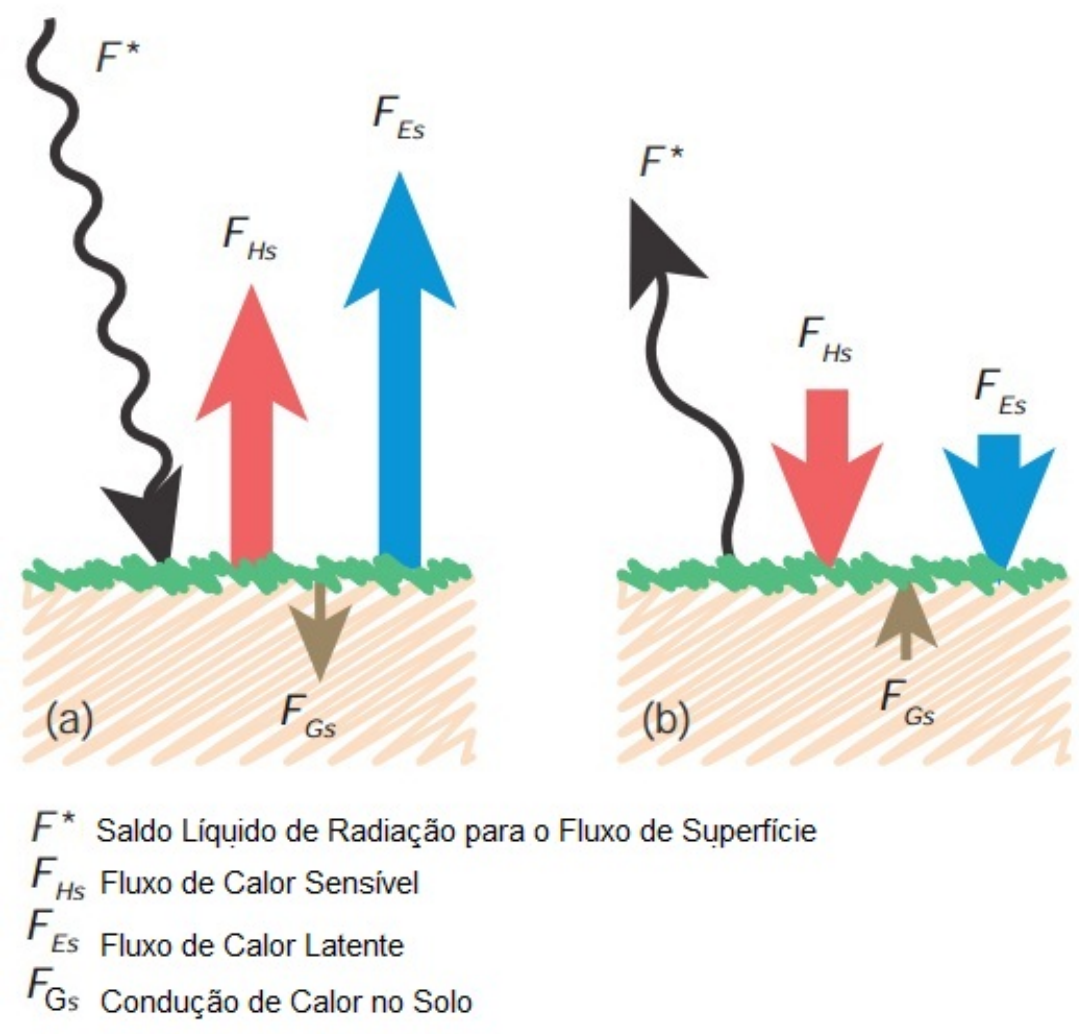

Figura 3.3: (a) Período Diurno (Fluxo Positivo) - (b) Período Noturno (Fluxo Negativo) [53]

Ou seja, pelo fato da CLP estar em contato direto com a superfície, ela sofre influência direta do solo, a qual consiste basicamente na troca de energia e na existência de um atrito viscoso, os quais tornam o escoamento nesta camada turbulento e permitem afirmar que a turbulência está diretamente associada ao fluxo vertical de calor. Portanto, tal camada possuirá características diferentes de acordo com o fluxo de calor sensível a que ela estiver exposta. Logo, é possível classificá-la em três tipos principais:

- CLE - Camada Limite Estável ou Camada Limite Noturna: Esta camada é formada quando o fluxo de calor sensível e latente é dado da atmosfera para a superfície (Fluxo Negativo); 
- CLN - Camada Limite Neutra: É gerada quando o fluxo de calor sensível e latente, seja da superfície para a atmosfera ou vice-versa, apresenta valores próximos a zero;

- CLC - Camada Limite Convectiva: A formação desta camada ocorre quando o fluxo de calor sensível e latente é dado da superfície para a atmosfera (Fluxo Positivo);

Devido aos fluxos de calor, pode-se afirmar que uma CLP formada em condições idealizadas (com céu claro e superfície homogênea) apresenta durante o período diurno características de CLC e, durante a noite características da CLE e, durante as transições entre uma e outra características de CLN [32].

\subsubsection{CLE - Camada Limite Estável}

Nos casos em que a superfície se encontra mais fria do que a camada de ar adjacente, esta perde calor para a superfície, ocasionando um fluxo de calor negativo, o qual dentro de algum tempo, tornará a mesma fria e densa. Este processo que ocorre logo após a fase de decaimento da convecção caracteriza a formação da Camada Limite Estável. Sendo a estabilidade atmosférica definida como "a tendência de uma parcela de ar em se mover verticalmente" [33], essa camada recebe este nome devido a sua estabilidade, a qual pode ser observada a partir do perfil da temperatura potencial virtual $\left(\theta_{v}\right)$ (Fig. 3.4), onde temos que $\frac{\partial \theta_{v}}{\partial z}>0$, indicando que a temperatura das parcelas de ar se elevará de acordo com o aumento da altura [32].

Devido a necessidade do fluxo de calor ser negativo (atmosfera cede calor para superfície), a CLE geralemente é formada durante a noite, por este motivo ela também é identificada por alguns autores como Camada Limite Noturna.

O processo de formação da CLE se inicia quando a superfície se encontra mais fria que a camada de ar adjacente, devido à interrupção, ou diminuição, da radiação solar incidente. Com isso, o fluxo se torna negativo e a superfície passa a ceder calor 


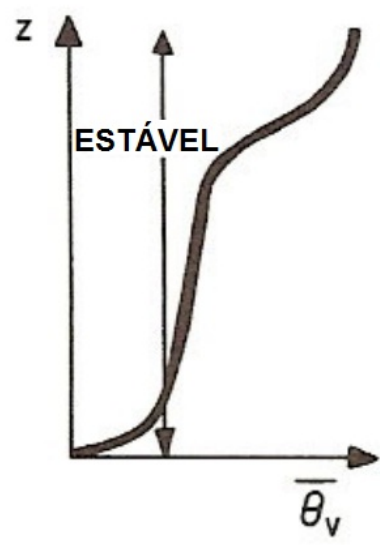

Figura 3.4: Perfil da Temperatura Potencial Virtual ao longo da CLE e a Estabilidade Atmosférica [45]

para o solo. Este processo vai se expandindo gradualmente, gerando o aumento da magnetude do fluxo de calor e o crescimento da CLE [2, 53].

A princípio a CLE é bastante fina, mas com o avançar do processo, ela pode chegar a cerca de 300 metros. Ela possui valores extremamente reduzidos de tensão média de cisalhamento e fluxo de calor [19]. Esta complexidade torna a CLE na maioria das vezes mal definida.

Segundo Garrat [19], a CLE possui uma estrutura de três sub-camadas, as quais podem ser distinguidas conforme o resfriamento. Sendo $h$ a altura total da CLE, temos:

- (I) Primeiro, ou parte baixa: esta sub-camada coincide com a camada superficial ( $z<0,1 h)$. É dominada pela radiação.

- (II) Esta região representa a maioria da $\operatorname{CLE}(0,1 \mathrm{~h}<\mathrm{z}<0,8 \mathrm{~h})$. Ela é dominada pelo resfriamento turbulento e possui temperatura potencial variando de forma aproximadamente linear.

- (III) É a parte mais alta da $\operatorname{CLE}(0,8 \mathrm{~h}<\mathrm{z}<\mathrm{h})$. Nesta região prevalece 0 resfriamento radiativo.

Os poluentes emitidos na CLE, se dispersam muito pouco na vertical, ocorrendo maior nível de dispersão na direção horizontal. Com isso, os mesmos ficam retidos nos níveis mais baixos, sendo liberados para níveis maiores somente após o amanhecer [45]. Isto tem uma larga gama de implicações práticas, incluindo episódios de poluição 
urbana, transporte de pesticidas, etc, sendo um dos exemplos mais comuns o caso de Inversão Térmica, onde as massas de ar quente impedem a ascenção das massas de ar frio que estão logo abaixo destas. Com isso a dispersão de poluente também é prejudicada, causando um aumento na concentração dos mesmos.

É possível que ocorra formação da CLE em períodos diferentes do esperado, como por exemplo durante o dia. Para que isto ocorra é necessário que a superfície subjacente esteja mais fria do que o ar, para assim caracterizar o fluxo negativo de calor.

\subsubsection{CLN - Camada Limite Neutra}

Ao longo das horas, o fluxo de calor sofre variações, indo de valores positivos (durante o dia) a negativos (durante a noite). Isto sugere que em determinados momentos, mais precisamente nos períodos de transição, quando o valor do fluxo muda de negativo para positivo ou vice-versa, o mesmo tenha um valor nulo ou muito próximo de zero. É neste instante que se forma a Camada Limite Neutra. Portanto, a CLN pode ser definida como a camada onde a temperatura não varia com a altura e a superfície do solo não atua como fonte de energia térmica. Esta combinação de fatores faz com que o fluxo de calor sensível seja nulo ou muito próximo de zero [32]. Esta camada também é caracterizada por possuir uma variação nula $\left(\frac{\partial \theta_{v}}{\partial z}=0\right)$ ou muito próxima de zero $\left(\frac{\partial \theta_{v}}{\partial z} \approx 0\right)$ no perfil de $\theta_{v}$, o que representa neutralidade em questões de estabilidade atmosférica (Fig. 3.5) [45].

A CLN é geralmente encontrada sobre oceanos, devido a inércia térmica nesta região. Sobre o continente este tipo de camada é formada geralmente quando há uma grande incidência de fortes ventos superficiais, os quais atrapalham os fluxos de calor tornando-os nulos.

No entanto, assim como nos outros casos de formação de camada, a CLN também pode ser formada fora dos períodos esperados (início da manhã e final da tarde). Como exemplo é possível citar os dias de céu encoberto, onde as nuvens tendem a realizar um "efeito estufa", impedindo que a superfície perca calor para a atmosfera. 


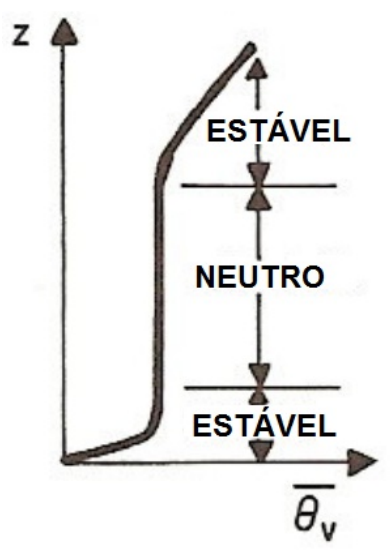

Figura 3.5: Perfil da Temperatura Potencial Virtual na CLN e a Estabilidade Atmosférica [45]

As mesmas também atuarão como refletores da radiação solar incidente, evitando assim que a superfície se aqueça. Estes dois eventos somados, fazem com que o fluxo de calor seja exatamente ou quase nulo.

\subsubsection{CLC - Camada Limite Convectiva}

Com o nascer do Sol, há um aumento na intensidade de radiação sobre a superfície. Isto permite que cerca de meia-hora após o amanhecer, o solo esteja parcialmente aquecido e ocorra uma alteração no fluxo de calor, o qual se torna positivo.

Então, surgem movimentos convectivos vindos da parte mais baixa da atmosfera, os quais ultrapassam rapidamente os ventos turbulentos e cisalhados. Estes fluxos sobem e destroem, de forma gradual, a CLE e a substituem pela Camada Limite Convectiva [20]. A velocidade deste processo dependerá da intensidade de estratificação da CLE.

Com o avançar das horas, há um aumento nos processos convectivos, devido ao aumento do fluxo de calor sensível na superfície. Desta forma a CLC que a princípio, se mostrava mal definida, começa a crescer e passa a tomar uma forma padrão, a qual pode ser subdividida em três partes:

- Camada Limite Superficial (CLS): se extende do solo até $10 \%$ da altura da CLP. Nesta região ocorre a primeira inversão de temperatura 
- Camada de Mistura (CM): Esta região está situada entre a CLS e a ZE

- Zona de Entranhamento (ZE): É a região a camada situada imediatamente acima da CM e está em contato direto com a Atmosfera Livre.

O Crescimento da CLC está diretamente associado ao fluxo de calor da superfície e as características de estabilidade sobre a atmosfera livre. Ela atinge seu tamanho máximo durante a tarde, momento em que a turbulência na $\mathrm{CM}$ se mostra mais forte. A CLC pode atingir em dias de céu claro até $2 \mathrm{Km}$.

Após o pôr-do-sol, o processo de convecção começa a se enfraquecer, de tal forma que depois de algumas horas, ele é completamente encerrado. Assim, o processo de mistura é interrompido, gerando alterações no fluxo de calor, criando uma CLN (nos instanstes de fluxo próximo ou igual a zero) e posteriormente uma CLE, quando o fluxo se tornar negativo.

Esta camada é caracterizada por possuir uma variação negativa $\left(\frac{\partial \theta_{v}}{\partial z}<0\right)$ no perfil de $\theta_{v}$, o que representa uma camada instável (Fig. 3.6) [45, 2].

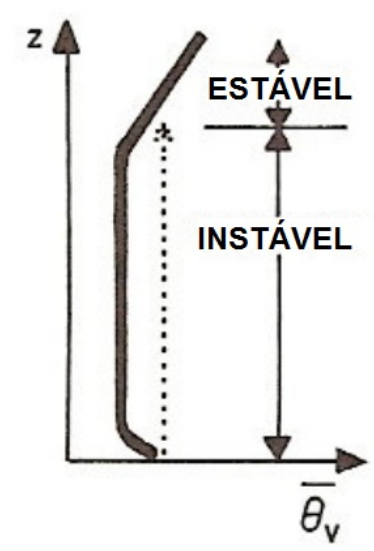

Figura 3.6: Perfil da Temperatura Potencial Virtual na CLC e a Estabilidade Atmosférica [45]

\subsubsection{Ciclo da CLP}

Além dos três tipos de CLP apresentados acima, existem outras sub-camadas, que atuam como divisões e/ou regiões de transição das camadas principais, conforme ilustra a Figura 3.7. 


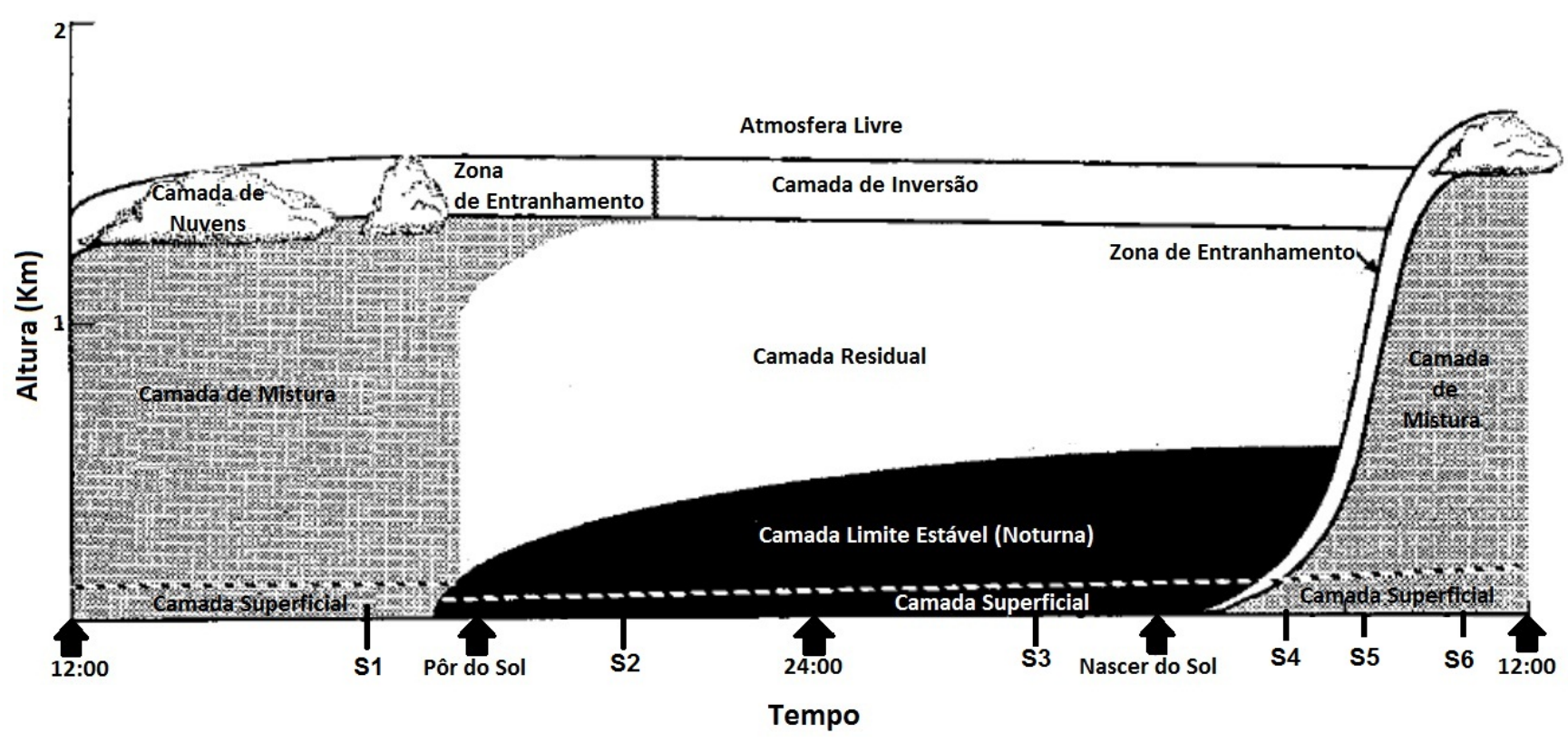

Figura 3.7: Evolução temporal da CLP - Adaptado de [45]

Na mesma figura é possível observar que independentemente do período, há uma camada contínua denominada Camada Limite Superficial (CLS). Tal camada possui intensos gradientes verticais de umidade, velocidade do vento e temperatura. Durante o dia ela possui uma alta concentração de térmicas, as quais se fundem e formam turbilhões maiores e mais organizados na CLC ou Camada de Mistura (CM), a qual pode ser assim chamada devido a forte mistura na sua parte interna, indicando a existência de grande turbulência oriunda de intensa convecção [32, 45, 53].

A CM surge cerca de meia-hora após o nascer do Sol e cresce de acordo com o aquecimento do solo a partir da radiação solar. Portanto a mesma sofrerá aumento de profundidade ao longo do dia devido a processos de arrasto e mistura interna, alcançando o seu máximo no fim da tarde. Nesta camada as taxas de mistura tendem a diminuir com a altura, assim como a temperatura potencial virtual (Fig. 3.8) [19].

Uma camada estável no topo da CM atua como uma tampa para as termas que sobem, o que restringe o domínio da turbulência. Tal camada é chamada Zona de Entranhamento (ZE) (Fig. 3.7 e 3.8). Tal camada atua como uma interface entre a Atmosfera Livre e a CLP, tornando-a bem definida em condições convectivas [32, 53]. Nesta região não há uma forte mistura e a intensidade da turbulência decai com a altura, devido a alta estabilidade. $O$ topo da mesma geralmente não ultrapassa $2 \mathrm{Km}$. 
A concentração de poluentes pode aumentar dentro da CM e permanecer relativamente baixa na $A L$, pois os mesmos em sua maioria são oriundos de regiões próximas a superfície e são transportados para regiões superiores por vórtices. No entanto estes não podem avançar muito em camadas estáveis, como a ZE, por exemplo. Desta forma a ZE pode atuar como uma barreira aos poluentes, mantendoos na CM [45].

Outra importante camada é a Residual (CR), a qual é proveniente da dissipação térmica da CLC. Ela surge cerca de meia hora antes do pôr do Sol, causando uma redução no fluxo de calor da superfície e o decaimento da convecção. A mesma recebe este nome por deter características remanescentes da camada de mistura formada durante o dia, ou seja, as mesmas variáveis de estado e concentração, além de reter os poluentes, os quais ficarão ali confinados durante o período noturno. Com o progresso da noite, a parte baixa desta camada se transforma em CLE [19, 32].

A CR se mantém por um tempo de manhã, antes de ser entranhada em uma nova CM. Durante este tempo a radiação solar pode provocar reações fotoquímicas entre os consituintes da CR.

Para esta camada a umidade frequentemente se comporta como um traçador passivo. A cada dia, um volume maior de umidade pode ser evaporado de dentro da $\mathrm{CM}$ e ser retida na CR. Durante sucessivos dias, o re-entranhamento do ar úmindo na CM permitirá a formação de nuvens.

A temperatura potencial geralmente decresce lentamente durante a noite, devido a divergência da radiação. Sendo a taxa de resfriamento praticamente uniforme ao longo da CR.

Durante a noite, a parte final da CLP é limitada verticalmente pela Camada de Inversão (CI), a qual, assim como a ZE (que ocorre durante o dia), atua como uma interface entre a Atmosfera Livre e a CLP, tornando-a bem definida em condições convectivas [32, 53]. Nesta região não há uma forte mistura e a intensidade da turbulência decai com a altura, devido a alta estabilidade. Em noites de céu claro, a $\mathrm{Cl}$ atinge a marca média de $300 \mathrm{~m}$. Em casos de alta estabilidade, esta região impede a saída de poluentes da CLP. 
Na figura 3.8 é mostrado o perfil vertical das principais variáveis de estado (Temperatura $(\mathrm{T})$, Temperatura Potencial $(\theta)$ e Umidade relativa $(\mathrm{q})$ ), passando por toda a CLP e chegando a Atmosfera Livre (AL). Portanto, pode-se observar que tais variáveis possuem comportamentos característicos ao longo da estrutura vertical da atmosfera, e estes permitem identificar a altura de cada subcamada.
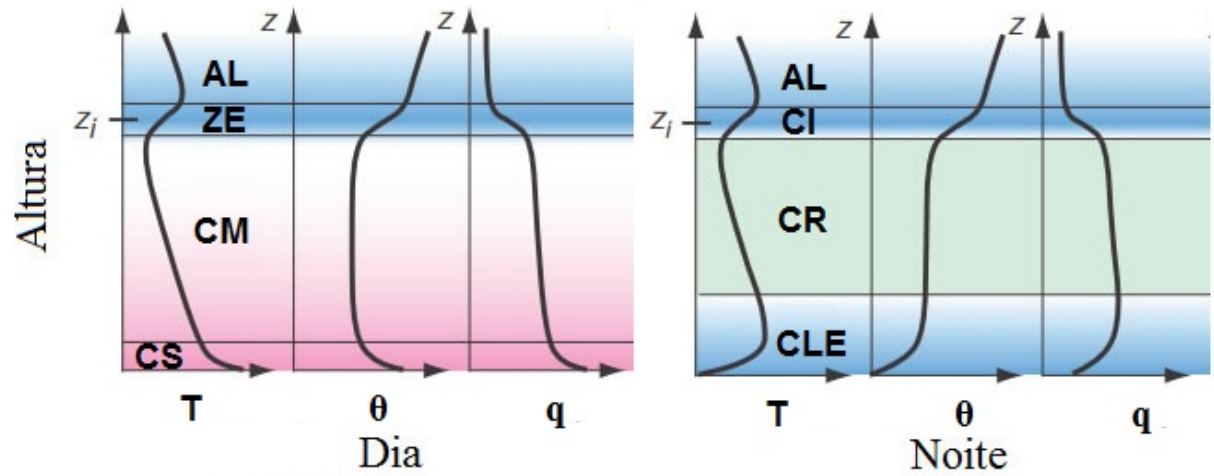

Figura 3.8: Perfil das variáveis de estado - Adaptado de [53]

Em especial, os valores da temperatura potencial virtural $\left(\theta_{v}\right)$, propiciam a obtenção de conhecimento sobre a evolução da CLP como um todo e também das subcamadas, como mostra a figura 3.9 em conjunto com a 3.7. Iniciando em S1 (período pouco antes do pôr-do-Sol), é possível observar a presença de uma grande camada de mistura, a qual dará origem a uma CR e a uma CLE logo após o pôr-do-Sol (S2). As mesmas assumem formas mais definidas em S3 e após o nascer do Sol (S4), começa a surgir uma nova CM, a qual rompe a CLE em S5 e a CR em S6.

\subsubsection{CLU - Camada Limite Urbana}

Alterações na vegetação de uma determinada região, implicam em mudanças nas propriedades da superfície e consequentemente nos balanços de massa e energia [33].

A alocação de construções sobre uma determinada paisagem gera elevações nos fluxos térmico e radiativo ao redor deste ambiente. Portanto, processos como a urbanização, por exemplo, produzem mudanças radicais nas características radiativas, termodinâmicas e aerodinâmicas da superfícies que estão ao redor das áreas urbanas 
S1

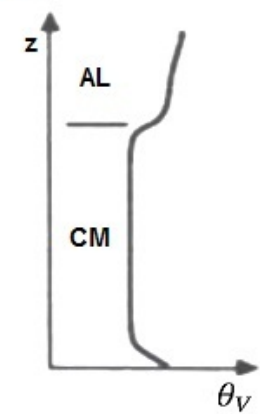

S4

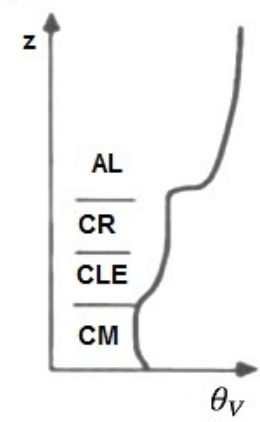

S2

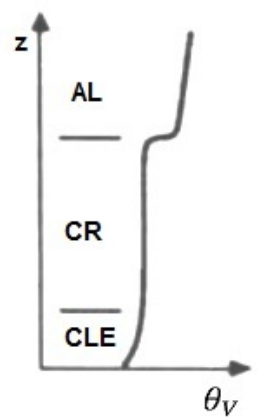

S5

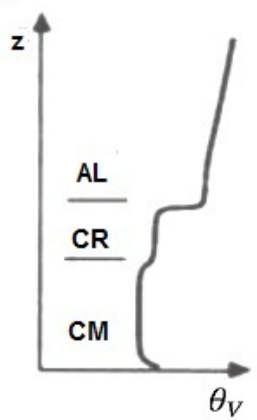

S3

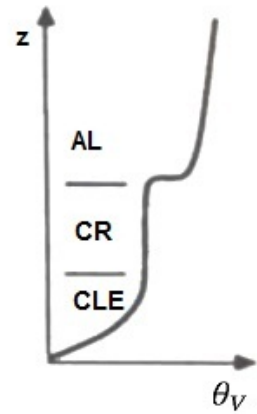

S6

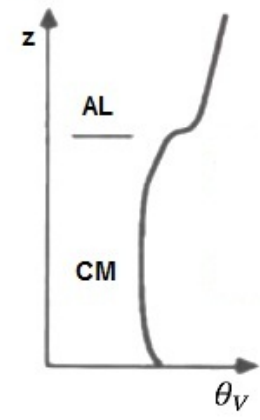

Figura 3.9: Evolução da CLP de acordo com as mudanças de temperatura potencial Adaptado de [45]

[2].

No fluxo radiativo, as alterações mais importantes são:

- A diminuição na recepção de radiação nas regiões sombreadas [2, 33];

- Aumento local na radiação solar recebida devido a reflexão das paredes iluminadas pelo Sol [2, 33];

- Variação no fluxos de saída de radiação de ondas longas $\left(L_{\uparrow}\right)$, devido a redução no fator de visão do céu [2, 33];

- Variações nos fluxos de calor latente $(L)$ [2, 33];

- Variação no fluxo de entrada de radiação de ondas curtas devido a passagem através da atmosfera poluída [2, 33];

O balanço de água também sofre alterações, causadas principalmente pelas características de drenagem e evaporação do solo. O fluxo de ar também passa por mudanças, uma vez que as construções passam a atuar como obstáculos para o vento [33]. 
O efeito climático, oriundo da urbanização, mais frequente é a elevação na temperatura da superfície e do ar sobre as áreas urbanas em comparação com os arredores rurais. Tal fenômeno é conhecido como Ilha Urbana de Calor. A Fig. 3.10 ilustra este fenômeno para uma cidade em uma noite sem nuvens, mostrando o perfil da variação de temperatura do ar, inciando-se na região rural e indo até o centro da cidade. É possível observar um "penhasco"(elevação brusca) no aumento da temperatura do ar próximo aos limite rural-periferia, seguido por um "platô"(elevações mais suaves) sobre a maioria da área periférica e um "pico"na temperatura sobre o centro da cidade representado por $\Delta T$ e corresponde a máxima diferença entre a temperatura da cidade e da região rural [33].

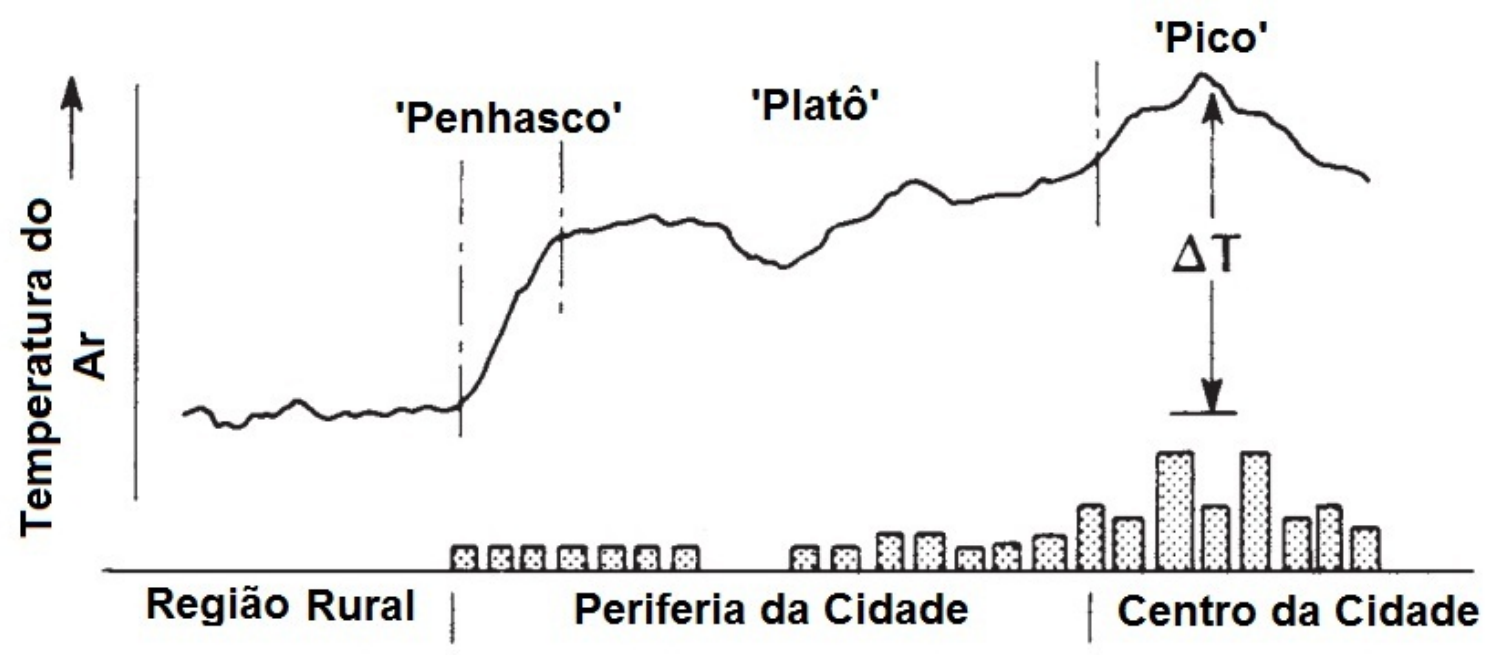

Figura 3.10: Variação na temperatura do Ar desde uma região Rural até o Centro da Cidade. Adaptado de [33]

A intensidade de uma ilha de calor depende de muitos fatores, tais quais: o tamanho da cidade, o consumo de energia, a localização geográfica, mês, estação do ano e hora. A intensidade máxima para a ilha de calor em uma dada cidade ocorre em condições de céu claro, poucas horas após o pôr-do-sol. A intensidade se torna mínima ou zero sob tempestades e/ou condições de ventania [2]. Sob condições sinóticas de tempo razoavelmente estacionárias, a intensidade da ilha de calor mostra uma pronunciada variação diurna com um valor mínimo próximo ao meio-dia e um máximo por volta ou após a meia-noite [33].

As principais condições que propiciam o surgimento de ilha de calor são: 
- Aumento no estocagem de calor durante o dia, devido as propriedades térmicas dos materiais urbanos [2];

- Aumento na absorção de radiação de ondas curtas pelo dossel urbano [2];

- Adição de calor antropogênico na área urbana devido aos processo de emissão das operações industriais e veículos automores [2];

- Diminuição na evaporação e, consequentemente, no fluxo de calor latente devido a remoção da vegetação e impermeabilização da cidade [2];

Portanto é possível afirmar que o processo de urbanização, ao causar mudanças na natureza da superfície, consequentemente implicará em alterações nas propriedades atmosféricas da região.

A CLP, sobre uma superfície ideal, mantém equilíbrio com as características da superfície local, sendo horizontalmente homogênea, principalmente quando não há alterações rápidas das características sinópticas. Porém em casos de inomogeneidade (transição entre: diferentes tipos de vegetação, aéras rurais e urbanas, tipos de relevo, etc), podem ocorrer alterações significativa sobre os fluxos atmosféricos [2]; Uma vez que ao realizar a travessia sobre as inomogeneidades, os fluxos encontrarão repentinas ou graduais mudanças na rugosidade, temperatura e umidade da superfície. Tal conjunto de mudanças implicam em alterações nas propriedades da CLP, gerando a Camada Limite Urbana (CLU) [2, 33].

CLU é a porção da CLP que está localizada sobre o dossel urbano. A mesma é modificada pela ilha de calor urbana e o aumento na rugosidade da superfície, a qual é oriunda da grande quantidade de construções que há nos grandes centros urbanos e, geralmente possuem maior concentração em direção ao centro da cidade [33].

A CLU diurna (Fig. 3.11) possui tanto a estrutura quanto a dinâmica muito similares a da CLC das áreas rurais, sendo a principal diferença o fato da CLU ser mais quente, turbulenta e poluída [2].

Durante a noite a CLU diminui em profundidade, atingindo cerca de 300 metros sobre o centro da cidade (Fig. 3.11), por conta da forte estabilidade existente, 

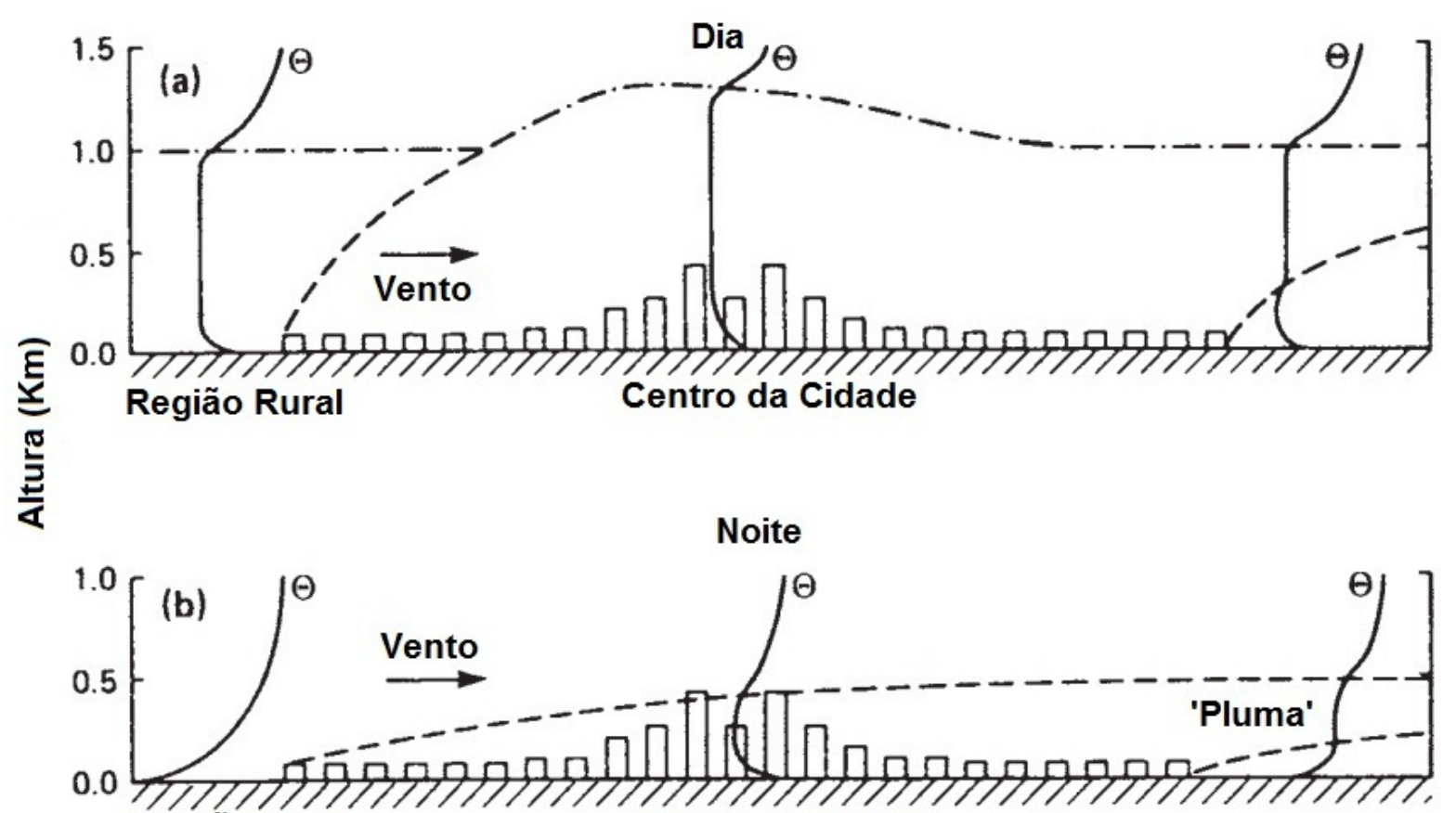

Região Rural Centro da Cidade

Figura 3.11: Perfil da temperatura potencial desde a região rural até o centro da cidade. Adaptado de [2]

mostrando que a mesma possui características similares a CLE [2]. O ar urbano que sofre advecção sobre esta camada é chamado pluma urbana.

\subsection{O sensoriamento Remoto}

A turbulência, gera dentro da CLP a mistura de várias substâncias oriundas da superfície, sendo que as mesmas podem se dispersar de forma horizontal e vertical dentro desta camada, caso não haja sumidouros para elas. Com isso, são gerados gradientes nos perfis verticais: da concentração de aerossóis e gases traço, e também de variáveis termodinâmicas, como por exemplo a temperatura potencial e a umidade relativa (Fig. 3.5) [53]. Portanto, é possível usar tais características como traçadores e combiná-las com técnicas de sensoriamento remoto, para conseguir identificar a profundidade da CLP.

Nas últimas décadas, a utilização de equipamentos de sensoriamento remoto tem permitido grandes evoluções nas análises do comportamento da CLP [20]. O sensoreamento remoto das variáveis da CLP pode ser feito de duas formas: 
- Passivo: o sensor capta a radiação eletromagnética emitida no espectro solar e/ou a radiação emitida no espectro terrestre. Por exemplo, a radiação solar interage com as nuvens e o sensor capta o sinal de espalhamento que pode ser usado para sua identificação, bem como, a radiação emitida pelo sistema terrestre e pela atmosfera, uma vez que estes podem ser utilizados para o estudo da sua composição. Exemplo: Radiômetro de Infravermelho [19].

- Ativo: o sensor capta a radiação espalhada ou retroespalhada pelo alvo que foi irradiado por uma fonte artificial, um gerador de microondas no caso do Radar ou um Laser. Uma parte dessa energia é retroespalhada, detectada e utilizada para análise da composição e estrutura da atmosfera. Exemplo: Lidar, RADAR, SODAR [19].

As técnicas de sensoriamento remoto são muito atraentes para a realização de estudos da atmosfera, uma vez que a mesma sofre grande influência dos fluxos de radiação. Em locais onde os métodos in-situ não apresentam bons resultados ou não são viáveis economicamente, o sensoriamento remoto também se mostra muito útil. As duas principais vantagens desta técnica são: a possibilidade de operação contínua e a não interferência no fluxo investigado [20].

Dentre as técnicas atuais de sensoriamento remoto, merce destaque o lidar, o qual devido a possibilidade de medidas com alta resolução temporal e espacial, fornecendo informações da atmosfera em condições reais, com a capacidade de cobrir intervalos de altura desde a superfície até centenas de quilômetros e, também por conta da sua grande utilização e bons resultados apresentados ao longo dos últimos anos [5, 4, 7, 10, 12, 31, 29, 22, 34, 44, 47, 48], tem sido considerado uma das principais ferramentas no estudo do perfil atmosférico.

\subsubsection{A técnica lidar}

O lidar (Llgth Detection And Ranging) é uma técnica de sensoriamento remoto da atmosfera que possui os mesmos princípios físicos do radar, porém ao invés de ondas de rádio é emitido um feixe de luz pulsado na direção da atmosfera [30]. 


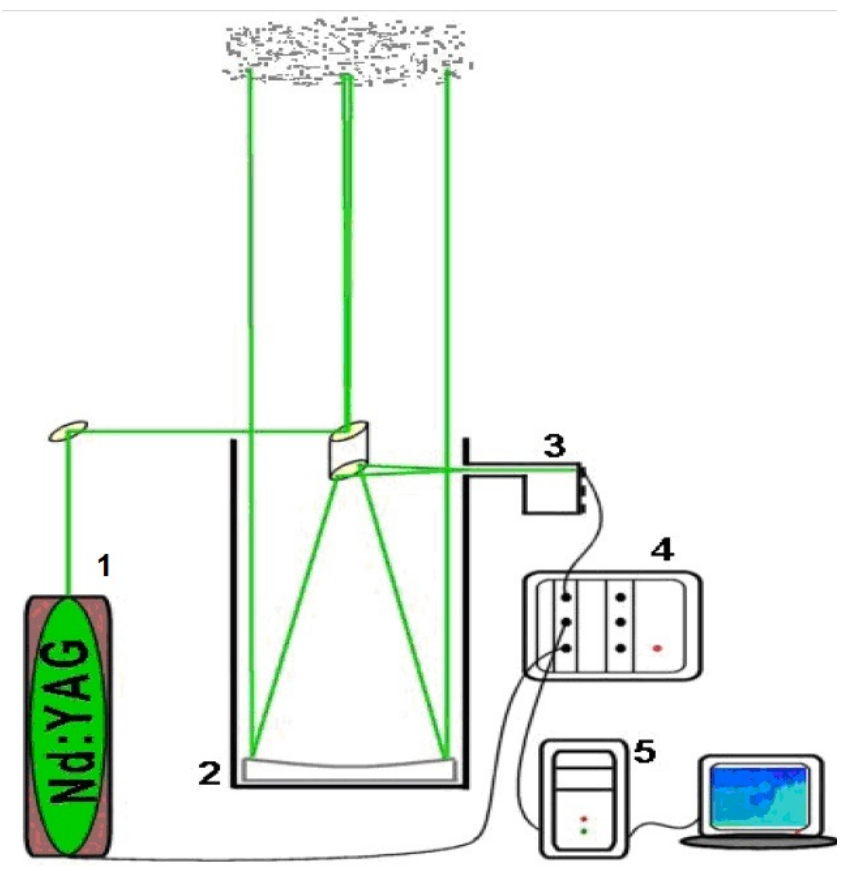

Figura 3.12: Representação de um Sistema Lidar (1 - Transmissor; 2 - Receptor; 3,4,5 - Detector [27]

O sistema lidar pode ser dividido em três partes básicas:

- Transmissor: É responsável por gerar pulsos luminosos e os direcionar para atmosfera, sendo composto por um laser que emite pulsos de luz curtos e intensos

- Receptor: Neste componente a luz retroespalhada é coletada por um telescópio e direcionada para um fotodetector, o qual converterá os fótons em sinais elétricos. Grande parte dos sistemas Lidar utilizam telescópios do tipo Cassegriano, devido ao seu design compacto, uma vez que este pode possuir a metade do comprimento de um telescópio Newtoniano (Fig. 3.13) [26].

- Detector: É responsável por captar a luz do receptor e fazer um registro do sinal em função da altitude. Ele é composto por um sistema de computador, o qual digitaliza o sinal elétrico em função do tempo e controla outras funções básicas do sistema.

Há dois tipos básicos de configuração para o sitema Lidar: Biestático e Monoestático. No primeiro o transmissor e o receptor ficam separados a distância considerável, para que desta forma seja possível obter uma boa resolução espacial, 

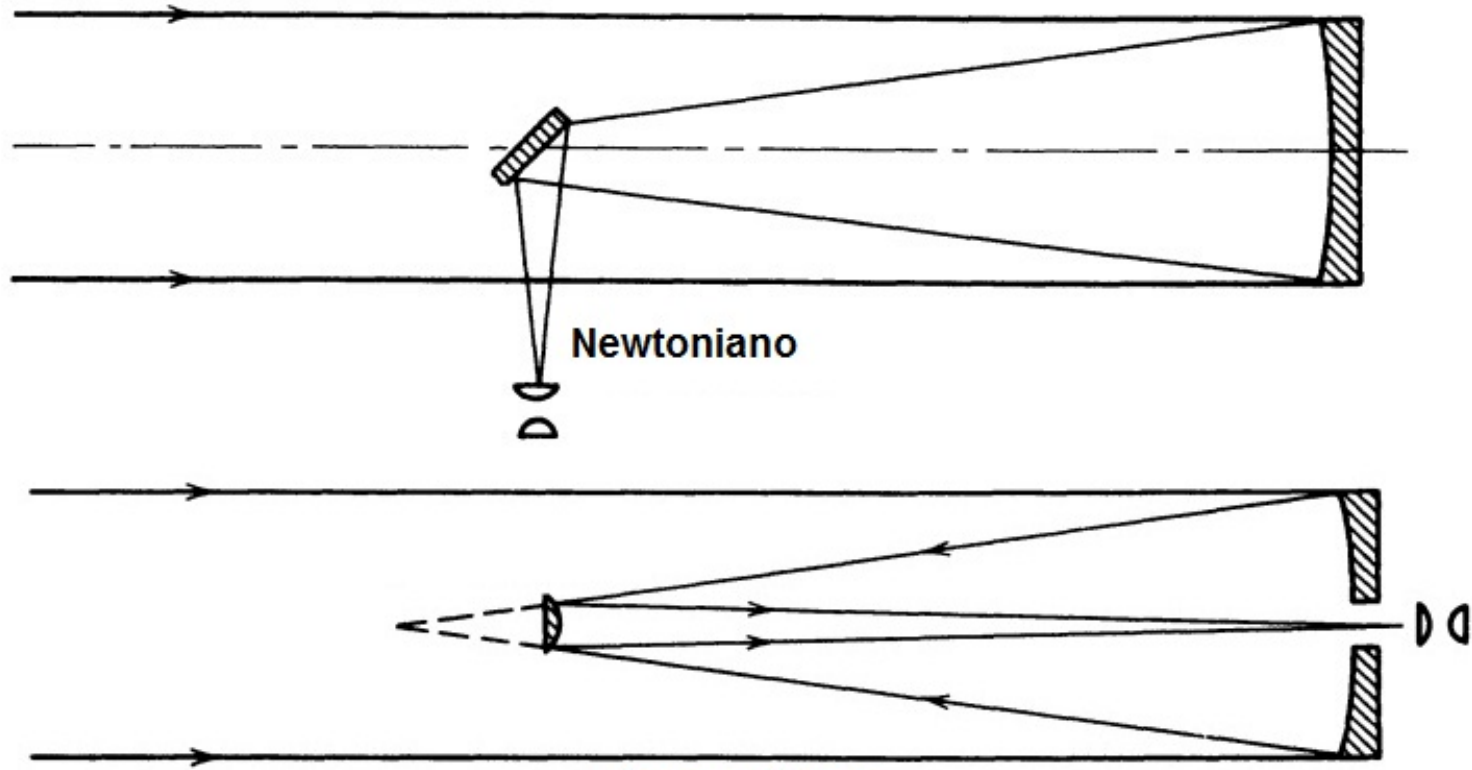

Cassegriano

Figura 3.13: Principais tipos de Telescópios utilizados pelo sistema LIDAR [26].

enquanto no segundo o receptor e o transmissor estão situados no mesmo local [30]. Atualmente o arranjo biestático está em desuso, uma vez que os lasers de nano segundos são capazes de proporcionar boas resoluções espaciais [26].

O arranjo monoestático pode ser subdividido em dois tipos Coaxial e Biaxial (Fig. 3.14). No caso coaxial o eixo do laser coincide com o do receptor, enquanto no biaxial o eixo do laser é paralelo ao do telescópio. Esta configuração evita o problema de saturação dos fotodetectores, porém não é tão eficiente opticamente quanto a coaxial [30]. As diferentes configurações geométricas do sistema causam alterações no overlap do mesmo, e dependendo da situação em que se deseja utilizar o lidar, isto pode ser um fator limitante.

O funcionamento do sistema lidar ocorre da seguinte forma (Figura 3.12): Um laser (componente 1), emite um feixe de luz com intensidade $F$. O mesmo se propaga através da atmosfera, sendo atenuado ao longo do percurso, pois a cada faixa de altura atingida, uma fração do feixe emitido é espalhada por partículas e moléculas da atmosfera. O fenômeno de espalhamento de luz atmosfera por partículas e moléculas é dividido em dois tipos: espalhamento elástico, onde a luz espalhada possui o mesmo comprimento de onda da luz emitida pelo laser, e espalhamento inelástico, onde o 
a

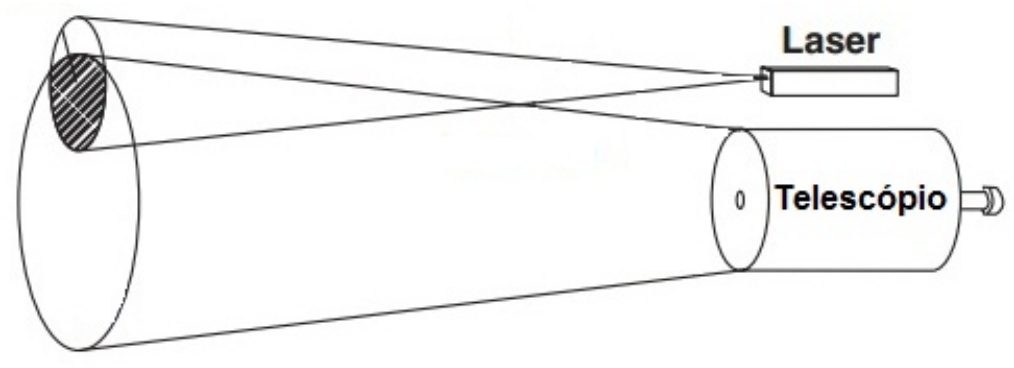

b

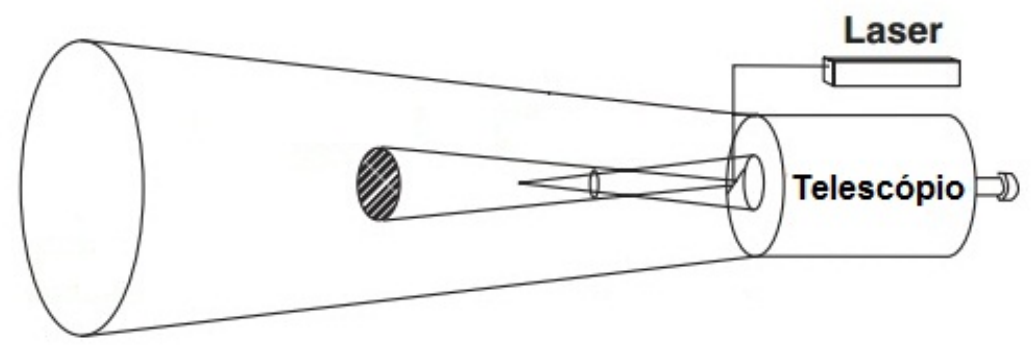

Figura 3.14: a - Sistema lidar Coaxial, b - Sistema lidar Biaxial

comprimento de onda da luz espalhada é diferente daquele da luz emitida [30, 26].

A luz espalhada é emitida em todas as direções relativas a direção da luz incidente, com determinada probabilidade de distribuição. Apenas uma pequena porção da luz espalhada (Luz retroespalhada - $F_{B S C}$ ), retorna ao sistema de detecção do Lidar, sendo coletada por um conjunto de instrumentos de óptica refrativa e reflexiva (um telescópio - componente 2), sendo que o telescópio é responsável por coletar e focar a luz sobre o fotodetector. Como a luz do laser é praticamente monocromática, são utilizados filtros de banda estreita para eliminar interferências, como por exemplo a luz oriunda de outras fontes, principalmente do Sol, com isso há uma melhora significante na atenuação do ruído do sinal e um aumento na faixa de medição do LIDAR [26].

Após a captação, o feixe é transferido para um detector de resposta rápida, uma fotomultiplicadora (PMT) ou detector de estado sólido (componente 3), no qual é gerado um sinal elétrico cuja intensidade em qualquer instante é proporcional à potência óptica recebida. Em seguida esse sinal é enviado a um sistema de detecção (componente 4) que o soma e garante a aquisição dos dados enviando-os para um computador (componente 5) [26].

Para o caso de um lidar monoestático, o sinal retroespalhado sobre o fotodetector $\left(F_{B S C}\right)$ é equivalente a seguinte soma: 


$$
F_{B S C}=F_{\text {Elast }, \text { Sing }}+F_{\text {Elas, Mult }}+\sum F_{\text {Inelas }} \quad 3.1
$$

onde temos que: $F_{E l a s, S i n g}$ é a radianção que sofre apenas um espalhamento elástico, $F_{\text {Elas,Mult }}$ é a radiação que sofre múltiplos espalhamentos elásticos, e $\sum F_{\text {Inelas }}$ corresponde a soma da radiação reemitida de forma inelástica, a qual é composta por comprimentos de onda deslocados com respeito ao comprimento de onda da luz emitida [26].

Em situações de atmosferas claras, há uma predominância do $F_{\text {Elast,Sing }}$ sobre o $F_{\text {Elas,Mult }}$, ocorrendo o contrário em casos de atmosferas turvas. Já o $\sum F_{\text {Inelas }}$ possui uma intensidade significantemente baixa (geralmente de diversas ordens de grandeza) em comparação a intensidade da luz espalhada elasticamente, podendo ser facilmente removido do sinal mediante a utilização de filtros ópticos [26].

Há ainda mais um componente que não foi mostrado na equação acima, a radiação de fundo $F_{B G R}$, o qual é composto por luz oriunda de outras fontes. Durante o dia este componente se apresenta mais fortemente devido a radiação solar, de tal forma que para a maioria das situações diurnas, o ruído irá eventualmente cobrir completamente o sinal Lidar a faixas distantes, tornando-se uma das principais limitações para o sistema [30].

Portando o fluxo total $\left(F_{T o t}\right)$ de radiação sobre o fotodetector será:

$$
F_{T o t}=F_{B S C}+F_{B G R} \quad 3.2
$$

Embora alguns sistemas lidar obtenham informações úteis a paritr da componente inelástica do sinal retroespalhado, na maioria das vezes é o $F_{\text {Elast,Sing }}$ que transporta este tipo de informações. Todas as outras contribuições para o sinal, são consideradas compoentes que corrompem a informação útil [26].

Como a velocidade de propagação da luz é conhecida, a distância do volume espalhador que produz o sinal é determinada a partir do intervalo de tempo entre a transmissão e a recepção do pulso. A magnitude do sinal recebido é determinada 
pelas propriedades de retroespalhamento da atmosfera em distâncias sucessivas e pela atenuação no caminho de ida e volta [26].

O retroespalhamento atmosférico, por sua vez, depende do comprimento de onda do laser, do número, tamanho, forma e propriedades de refração das partículas ou gotículas (ou moléculas) interceptadas pela luz incidente. Devido a intensdade da luz capturada pelo telscópio ser inversamente proporcional ao quadrado da distância do ponto de espalhamento ao Lidar, há uma grande diferença na intensidade da luz oriunda de curtas e longas distãncias (Fig. 3.15) [26].

De acordo com: o comprimento de onda utilizado no laser, o tipo de escaneamento realizado e o processamento óptico feito, no feixe que retorna ao telescópio, diferentes tipos de informações podem ser obtidas com relação a atmosfera, o que dá uma dinâmica maior para a utilização [30].

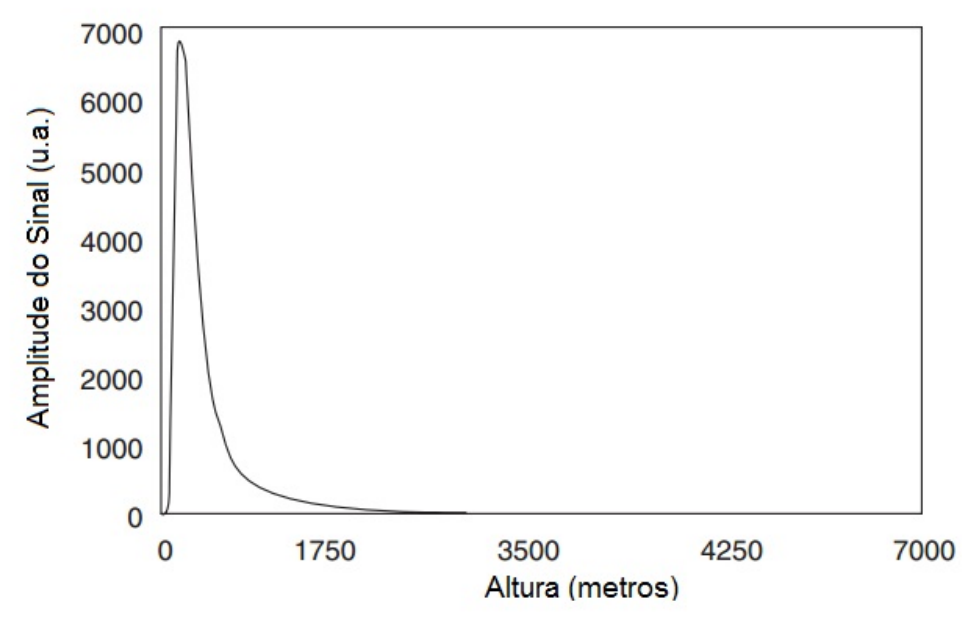

Figura 3.15: Perfil do sinal lidar

O comprimento dos pulsos emitidos, com relação ao tempo, normalmente são da ordem de 10ns. Está característica dá ao sistema Lidar uma resolução espacial bem superior a oferecida por outros sensores atmosféricos, como por exemplo, RADAR e SODAR [19]. A utilização de lasers de pulso longo (da ordem de microssegundos), complica o processamento e reduz a resloução espacial do Lidar [30].

Uma outra característica importante é a compacta seção transversal de espalhamento elástico, a qual faz com que o tempo necessário para escanear um determinado volume da atmosfera seja relativamente curto [26]. A união destas duas 
propriedades resulta em uma ferramenta capaz de examinar um largo volume do espaço, com fina resolução espacial, em um curto período de tempo, possibilitando um mapeamento atmosférico qualitativo [20].

Em situações apropriadas, a partir da utilização de Lidars, é possível obter perfis dos coeficientes do volume retroespalhado e de extinção, além da extinção total integral e a taxa de depolarização [19].Esses valores podem ser obtidos mediante a utilização da equação do Lidar (Equação 3.3), a qual é um importante instrumento matemático para investigação dos aerossóis atmosféricos, e envolve tanto os parâmetros ópticos e atmosféricos quanto os da geometria do sistema [30, 26, 20, 19].

Segue abaixo a equação clássica do Lidar:

$$
P(r)=P_{0} \frac{c \tau}{2} A \frac{\beta(r)}{r^{2}} \exp \left[-2 \int_{0}^{r} \sigma\left(r^{\prime} d r^{\prime}\right)\right]
$$

onde:

- $P(r)$ é o sinal [W] retornado da distânca $r$ no tempo $t$;

- $r$ é a distância [m] do volume investigado na atmosfera;

- $P_{0}$ é o sinal recebido [W] no tempo $t_{0}$;

- $c$ é a velocidade da luz $[\mathrm{m} / \mathrm{s}]$;

- $\tau$ é a duração do pulso do laser [ns];

- $A$ é a área $\left[m^{2}\right]$ da seção transversal do telescópio;

- $\beta(r)$ é o coeficiente de retroespalhamento $\left[(k m . s r)^{-1}\right]$ na distância $r$;

- $\sigma(r)\left[\mathrm{km}^{-1}\right]$ é o coeficiente de extinção na distância $r$;

No entanto são necessárias correções no sinal lidar. A primeira delas é com relação a radiação de fundo:

$$
P_{c f}(z)=P(z)-F_{B G R}
$$


Onde $P_{c f}(z)$ indica o sinal lidar corrigido com relação a radiação de fundo $\left(F_{B G R}\right)$, a qual e subtraída.

Em seguida, é necessária a realização de mais uma correção com relação a altura, devido a queda do campo eletromagnétio em função do quadrado da mesma. Então é tomado o quadrado da distância entre o ponto em questão da atmosfera e o receptor $\left(z^{2}\right)$, e feita a sua multiplicação pelo sinal corrigido na equação 3.4 :

$$
R C S(z)=P_{c f}(z) \cdot z^{2} \quad 3.5
$$

Onde RCS (Range Corrected Signal) é o sinal lidar após todas as correções.

Segundo Seibert[40], as principais vantagens do sistema lidar são:

- Possível de ser operado em solo e em aviões;

- Alta taxa de coleta de dados;

- Retorna sinais diretamente dos aerossóis;

E como principais desvantagens pode-se citar:

- Oneroso;

- Interpretação algumas vezes ambígua;

- Necessidade de traçadores;

- Intervalo com resolução limitada;

O lidar pode atuar como uma excelente ferramenta no mapeamento da estrutura da CLP, uma vez que possui alta resolução espacial e temporal, possibilitando a detecção de variações na concentração de partículas na atmosfera [26].

Enquanto 0 ar sobre a CLP é quase sempre seco e com uma pequena concentração de partículas, o oposto ocorre no topo da CLP, pois a medida que as plumas se elevam na atmosfera, elas se resfriam de forma adiabatica e, com isto 
ocorre um aumento na umidade relativa. Isto permite que particulas higroscópicas absorvam água e cresçam. Portanto, pode haver uma maior seção de espalhamento nas regiões próximas ao topo da CLP, o que ocasiona um aumento no sinal de retorno do Lidar [26, 19].

O topo da CLP pode também ser definido como: "A altura em que há equivalentes áreas com baixa concentração de partículas abaixo e acima de uma região em que a concentração é elevada" [26], e devido a boa resolução do sistema Lidar, é possível visualizar o topo da CLP a partir do emprego desta definição dentro de um perfil do mesmo, onde tal local será correspondente ao ponto médio da região de transição entre as áreas de alto e baixo retroespalhamento [26, 40]. Em um modelo idealizado do perfil Lidar (Fig. 3.16 - A), este ponto correponde a região de inflecção do gráfico.

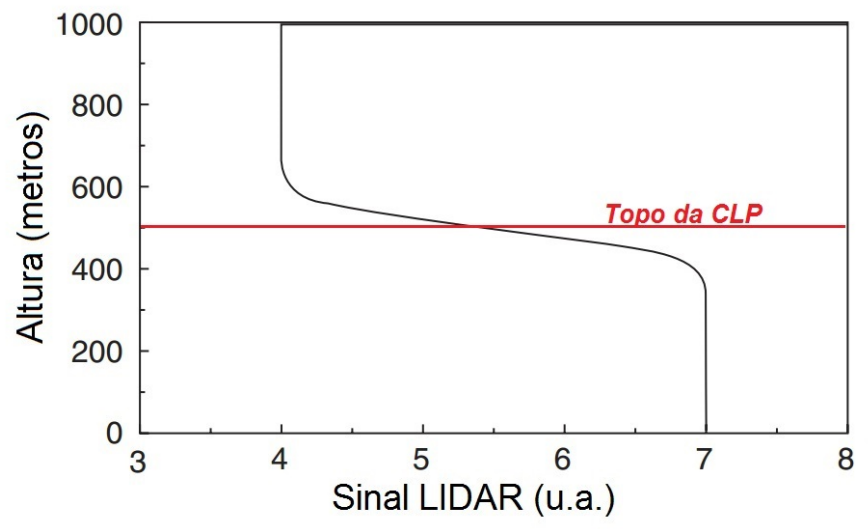

(A)

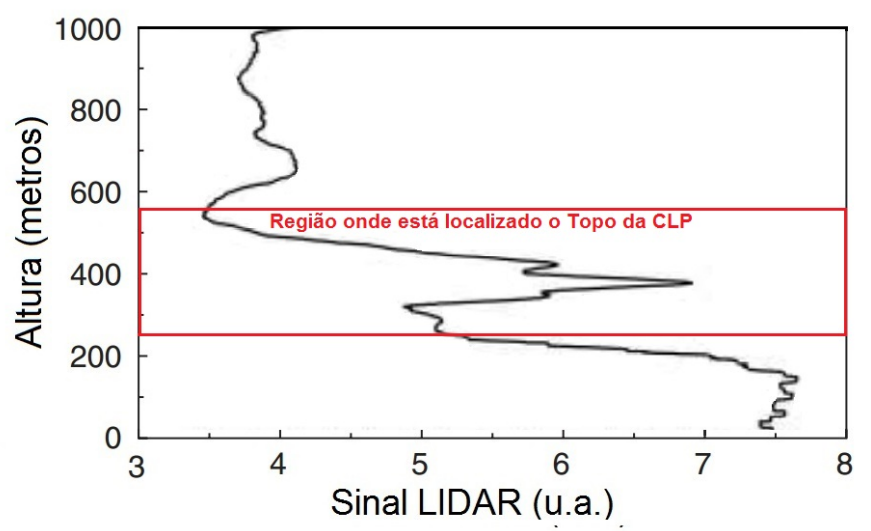

(B)

Figura 3.16: A - Perfil lidar idealizado. B - Perfil lidar real

No entanto a interpretação dos dados fornecidos pelo Lidar nem sempre é fácil e direta, sendo comum o aparecimento de várias subcamadas de aerossóis e/ou nuvens (Fig. 3.16 - B), devido a transportes advectivos e acumulações oriundas de processos anteriores. Além do mais a detecção do topo da CLP se torna complexa na presença de estratificações. Portanto, na maioria das vezes são necessários métodos que auxiliem, de forma clara e precisa, na obtenção de tais valores. 


\section{Capítulo 4}

\section{Metodologia}

\subsection{Coleta de Dados}

Para a construção deste trabalho foram utilizados dados de radiossondagem, cedidos pela Universidade de Wyoming e pelo projeto MCITY, e de Lidar, os quais foram captados nas seguintes campanhas:

- Campanha Vitória: Foi realizada no período de 23 a 30 de Julho de 2012, na cidade de Vitória - ES, no campus da Universidade Federal do Espírito Santo (UFES). Foram utilizados dois equipamentos de sensoriamento remoto: lidar e sodar (SOnic Detection and Ranging), os quais tiveram seus dados validados mediante a comparação com valores fornecidos por radiossongem (lançadas no aeroporto das Goiabeiras - Vitóra-ES às 12 UTC). Esta campanha foi realizada em colaboração com o IPMet-UNESP (Instituto de Pesquisas Meteorológicas da Universidade Estadual de São Paulo) e o Departamento de Engenharia Ambiental da UFES;

- Campanha MCITY - SP: Tal campanha ocorreu durante os dias 19 e 28 de Fevereiro de 2013 na cidade de São Paulo. O MCITY (Mega City Brazil Project) é um projeto que visa caracterizar os aspectos micrometeorológicos das duas principais áreas urbanas do Brasil (São Paulo e Rio de Janeiro). Os coordenadores são o Profo Dr. Amauri P. de Oliveira (IAG-USP - Instituto de 
Astronomia, Geofísica e Ciências Atmosféricas da Universidade de São Paulo) e o Prof. Dr. Edson P. Marques Filho (UFRJ - Universidade Federal do Rio de Janeiro). Durante esta campanha foram feitas medidas, no Campo de Marte SP, com radiossondas, as quais eram liberadas a cada 3 horas. Em paralelo ocorreram medidas lidar no prédio do IPEN-USP.

\subsection{Instrumentação}

O sistema lidar utilizado nas duas campanhas é móvel e do tipo biaxial (os eixos do transmissor e do receptor são paralelos) (Fig. 4.1). O mesmo foi desenvolvido pela Raymetrics Lidar Systems, e adquirido a partir de um projeto realizado em parceria com a Petrobrás.
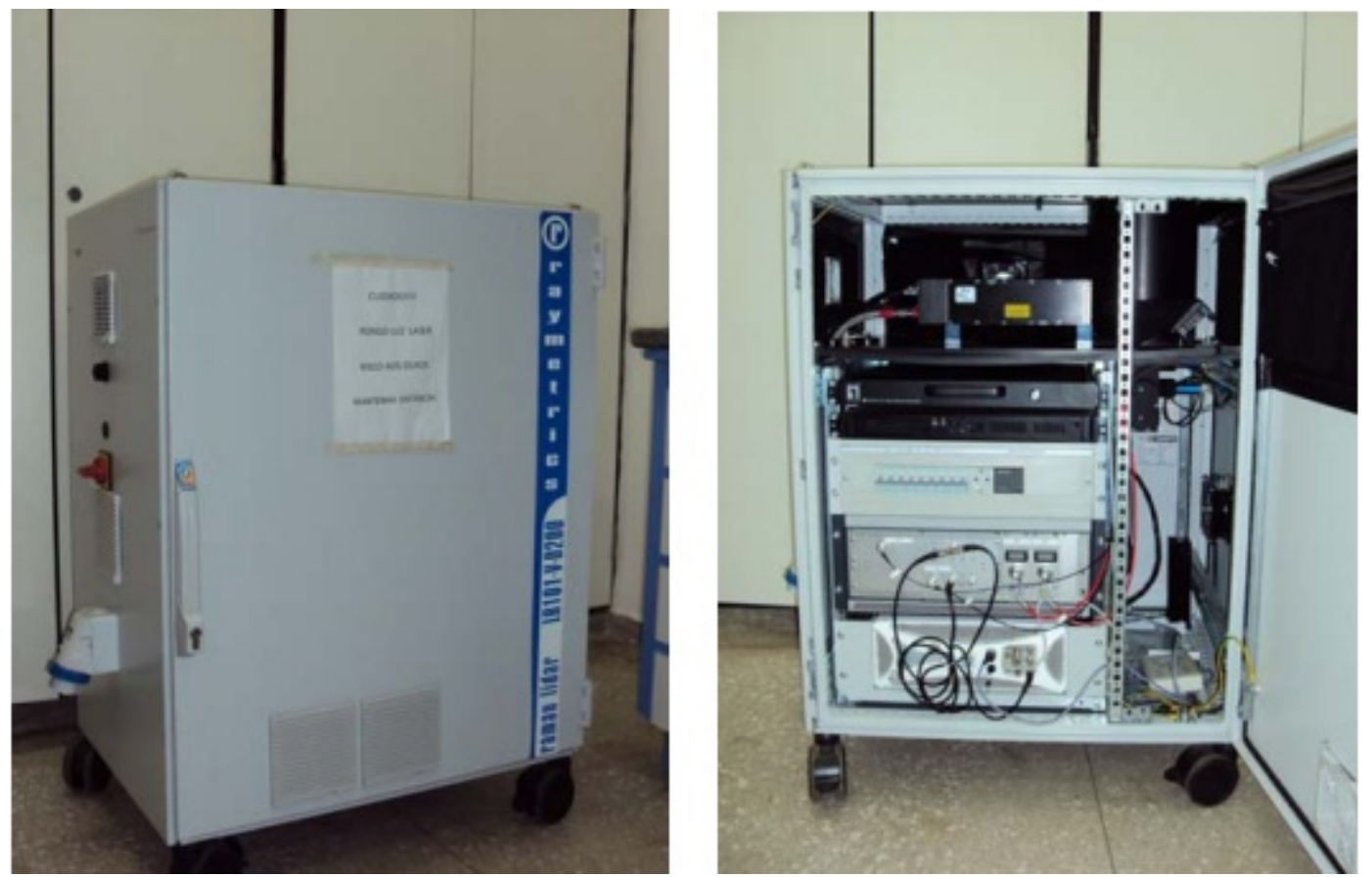

Figura 4.1: Sistema lidar Móvel

O transmissor do sistema é formado por um laser pulsado Nd:YAG modelo CFR 200, da Quantel S/A, o qual opera no comprimento de onda de $532 \mathrm{~nm}$, energia do pulso de $130 \mathrm{~mJ}$ e taxa de repetição de $20 \mathrm{~Hz}$.

O receptor é formado por um telescópio Cassegraniano de $200 \mathrm{~mm}$ de diâmetro, razão focal de 4,5 e um campo de visão que varia entre 1 e $2 \mathrm{mrad}$. 
O sistema de detecção é composto por duas fotomultiplicadoras modelo Hamamatsu R7400U estando cada uma alocada para um canal de detecção. O sinal que chega até as Fotomultiplicadoras é alocado em um registrador transiente chamado LICEL e armazenado em um computador. A conexão entre o computador e o LICEL é feita através de um programa desenvolvido em LabView, o qual realiza a correção do sinal bruto do lidar, transformando-o em RCS e em seguida realiza a união dos perfis individuais, obtidos dentro de um intervalo de tempo pré-definido, gerando um gráfico cortina, como mostra a Fig. 4.2(B).

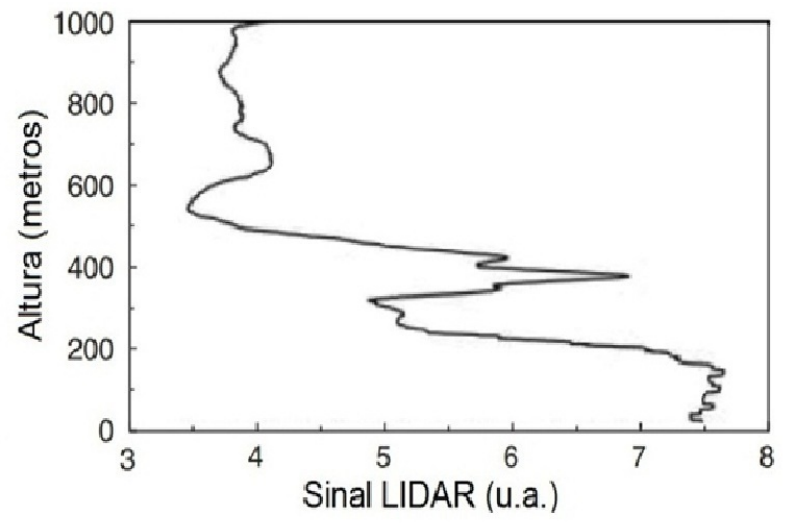

(A) Perfil do sinal lidar bruto

\section{Correções} com relação a radiação de fundo e altura

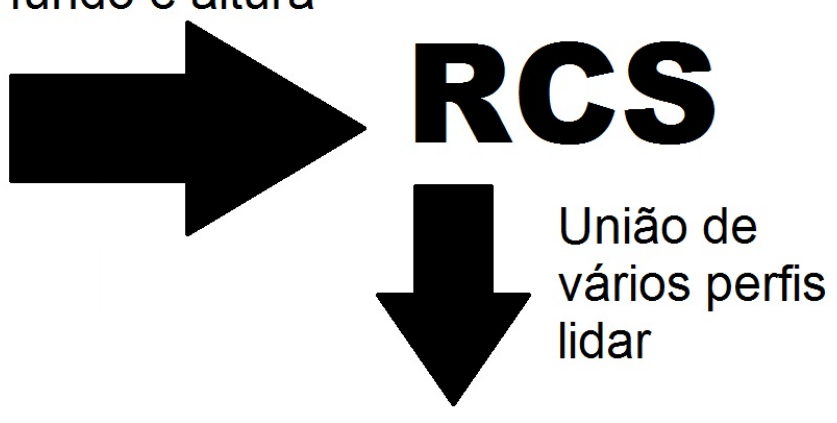

(B) Gráfico cortina

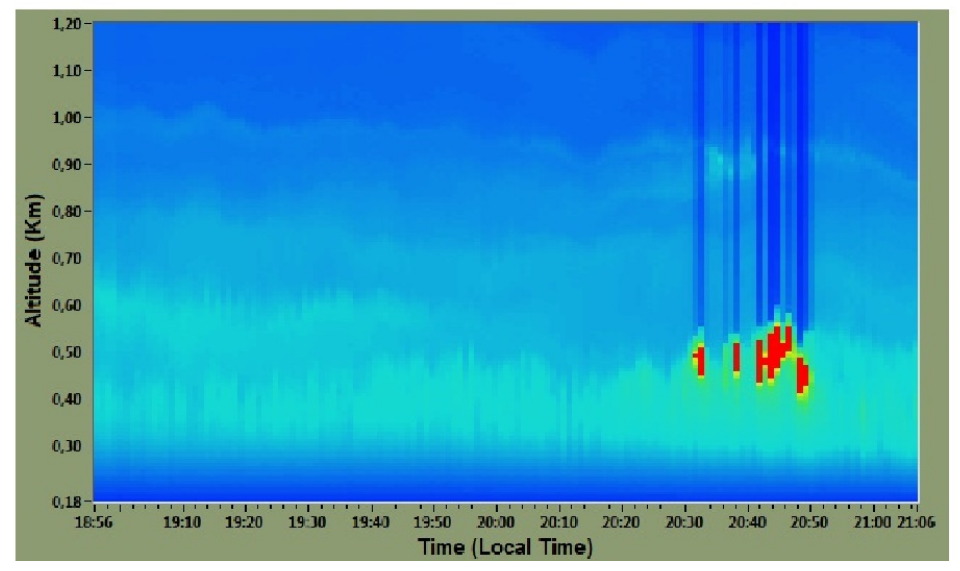

Figura 4.2: $O(A)$ Sinal lidar bruto sofrerá correções torando-se RCS. Os perfis serão unidos e darão origem ao (B) gráfico cortina.

A partir dos gráficos cortina é possível obter muitas informações a respeito do perfil da CLP. A Fig. 4.3, por exemplo, exibe um gráfico característico onde há retroespalhamento de alta intensidade na CLP, diminuindo através da Zona de Entranhamento, e tornando-se fraco na atmosfera livre.

A Fig. 4.4 demonstra os elementos que aparecem com mais frequência em um 


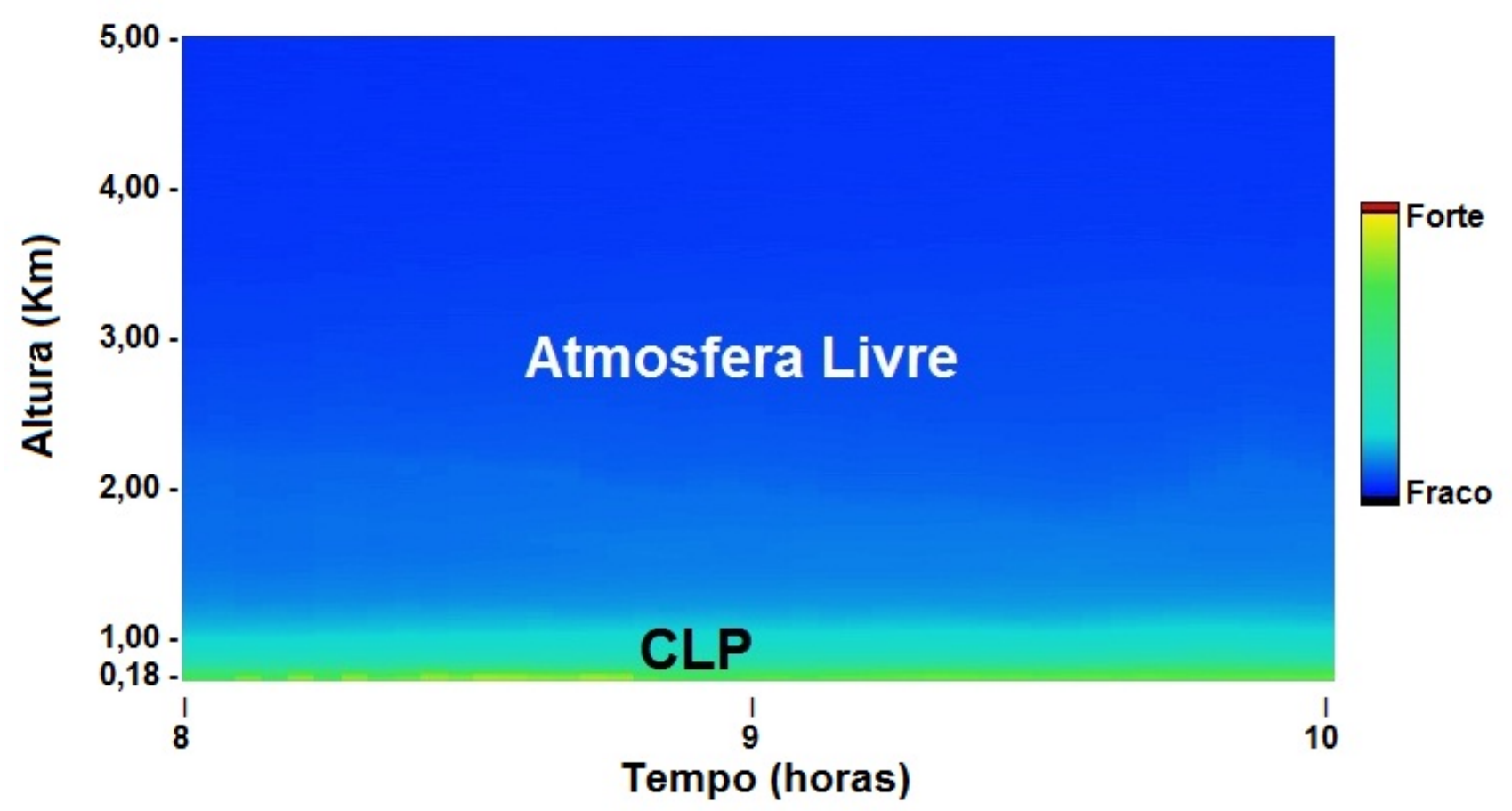

Figura 4.3: Perfil Vertical da Atmosfera gerado a partir de dados captados por um sistema lidar

gráficos cortina.

\subsection{Algoritmos para Análise de Dados}

A compreensão do comportamento da CLP e da sua altura máxima, são de extrema importância para o estudo e bom entendimento de diversos fenômenos atmosféricos, porém infelizemente a altura da CLP é difícil de ser modelada com precisão [12].

Uma das técnicas mais utilizadas para a obtenção do topo da CLP é a Radiossondagem, na qual é lançado para atmosfera um balão meteorológico contendo uma radiossonda, capaz de fornecer informações que permitem a obtenção de alguns parâmetros atmosféricos, como por exemplo: temperatura potencial, umidade relativa, etc. Logo a partir dos perfis característicos indicados na Fig. 3.8, é possível obter informações relativas a altura máxima da CLP. Porém a radiossondagem possui algumas desvantagens:

- Não permite monitoramento contínuo $\Longrightarrow$ Geralmente são lançadas apenas duas 


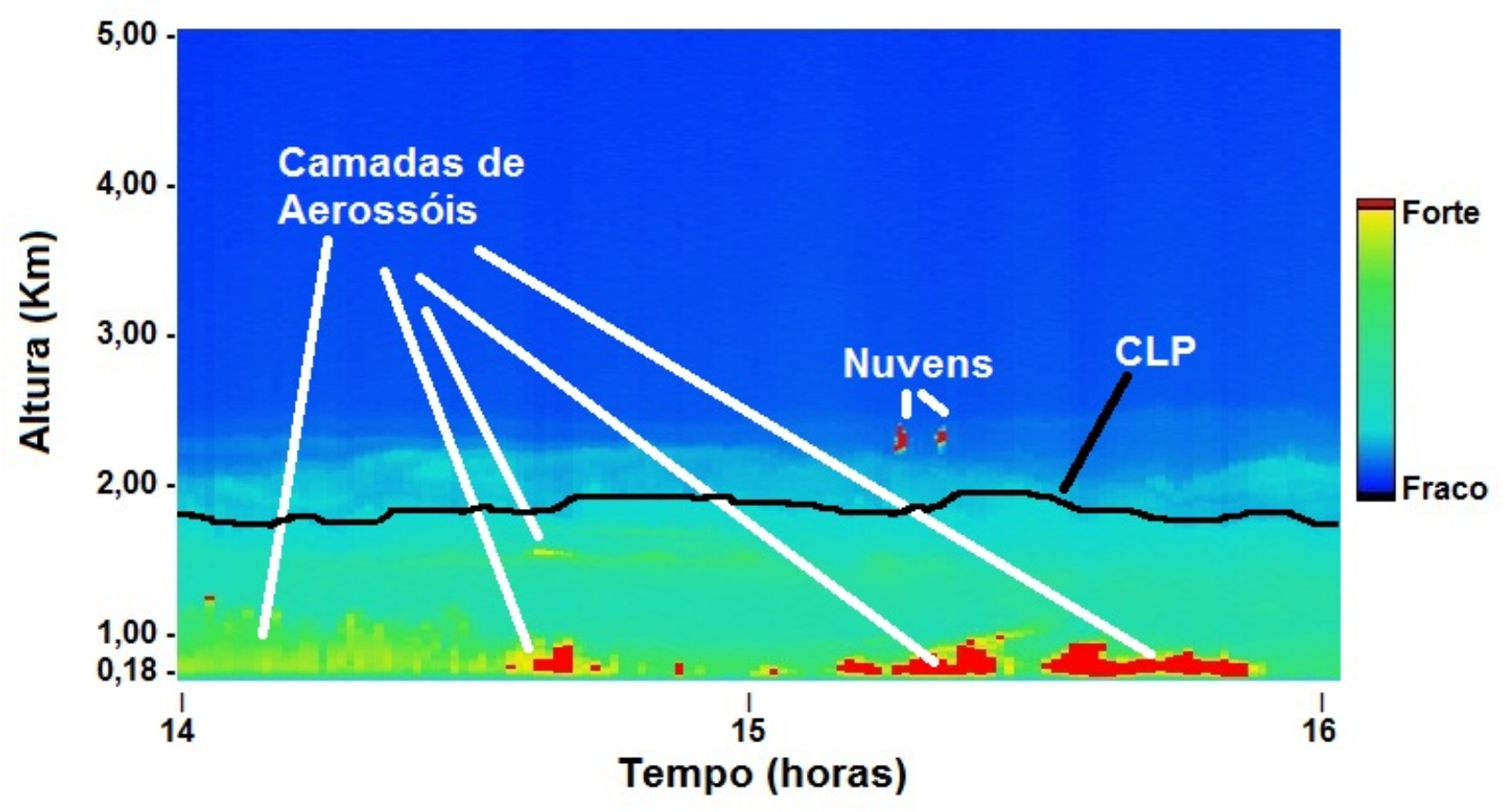

Figura 4.4: Perfil Vertical da Atmosfera

radiossondagens por dia [40];

- Problemas com resolução $\Longrightarrow$ Nem sempre as radissondagens possuem uma resolução espacial suficiente para fornecer bons resultados [40];

- Existência de retardos na transmissão de dados dos sensores $\Longrightarrow$ este problema se agrava com o acréscimo da altura, podendo gerar falhas na captação dedados [40];

- Problemas com deslocamento $\Longrightarrow \mathrm{O}$ vento pode interferir deslocando a radiossonda com relação ao eixo vertical em que ela está ascendendo;

Logo, embora seja uma técnica difundida, a radiossondagem nem sempre oferece resultados de boa qualidade.

O lidar, mesmo possuindo boa resolução espacial e temporal, necessita da utilização de algoritmos matemáticos que facilitem e/ou até se possível automatizem a detecção do topo da CLP. No entanto, na maioria dos casos a utilização de apenas um instrumento de medição não é suficiente devido as limitações que surgem dependendo do nível de complexidade em que se encontra a CLP, como por exemplo no caso de uma camada não estacionária [34], ou de múltiplas subcamadas. 
A seguir serão exibidos os cinco algoritmos matemáticos, que foram utilizados neste trabalho para a análise de dados. Sendo o primeiro aplicado aos dados de radiossondagem e os outros quatro aos dados de Lidar.

\subsubsection{Método Bulk Richardson Number (BRN)}

O BRN representa uma relação entre as energias potencial e cinética, podendo ser utilizado também como parâmetro de estabilidade e ferramenta para a obtenção da altura máxima da CLP a partir de dados radiossondagem [20, 40], e neste trabalho, ele será utilizado para a validação dos outros quatro métodos empregados, uma vez que eles dependem das informações do Lidar. A principal diferença entre as formulações do Número de Richardson Simples e o Bulk, é que o primeiro é aplicável apenas em condições estáveis, enquanto o segundo aplica-se também a condições de instabilidade, sendo portanto aplicável tanto a CLE quanto a CLC [45]. O Bulk Richardson Number $\left(R_{b s}\right)$, e pode ser obtido a partir da seguinte fórmula:

$$
R_{b s}=\frac{\frac{g}{\theta_{v s}}\left(\theta_{v z}-\theta_{v s}\right)\left(z-z_{s}\right)}{\left(u_{z}-u_{s}\right)^{2}+\left(v_{z}-v_{s}\right)^{2}+\left(b u_{*}^{2}\right)}
$$

Onde: $z$ representa a altura, $g$ o valor da aceleração da gravidade, $\theta_{v}$ é o valor da temperatura potencial, $u$ e $v$ são as componentes da velocidade do vento, sendo que os sufixos $s$ e $z$ referem-se a superfície e altura $z$, respectivamente; e $b u_{*}^{2}$ é um constante relacionada a efeitos superficias de fricção.

A partir da equação 4.1 , serão obtidos diversos valores, conforme houver variação na altura, e os mesmos serão comparados a um determinado valor crítico $R_{S}$. Quando for encontrado um ponto onde $R_{b s}<R_{S}$, isto indica alteração na estabilidade da atmosfera, logo a altura relativa ao mesmo corresponderá ao topo da CLP.

As principais vantagens desta técnica são [42]:

- Fornecer bons resultados em casos de CLP estáveis ou convectivas; 
- Não possuir forte dependência com a resolução vertical da sondagem, pois mesmo que a resolução vertical da radiossondagem seja baixa, é possível estimar a altura máxima da CLP por interpolação;

- Não necessita de valores dos fluxos verticais da superfície, uma vez que na maioria dos casos, estes valores nem sempre estão disponíveis;

Na Fig. 4.5 é mostrada uma comparação entre o BRN e uma outra forma de obtenção do topo da CLP a partir de dados de radiossondagem, o Método dos Perfis. Este método consiste em detectar o ponto de transição entre a CLC e a Camada de Inversão, o qual pode ser detectado a partir da $\theta$, uma vez que esta permanece quase constante dentro da CLC e sofre uma brusca alteração na Camada de Inversão, gerando uma inclinação bastante acentuada no gráfico da $\theta$ [14, 45].

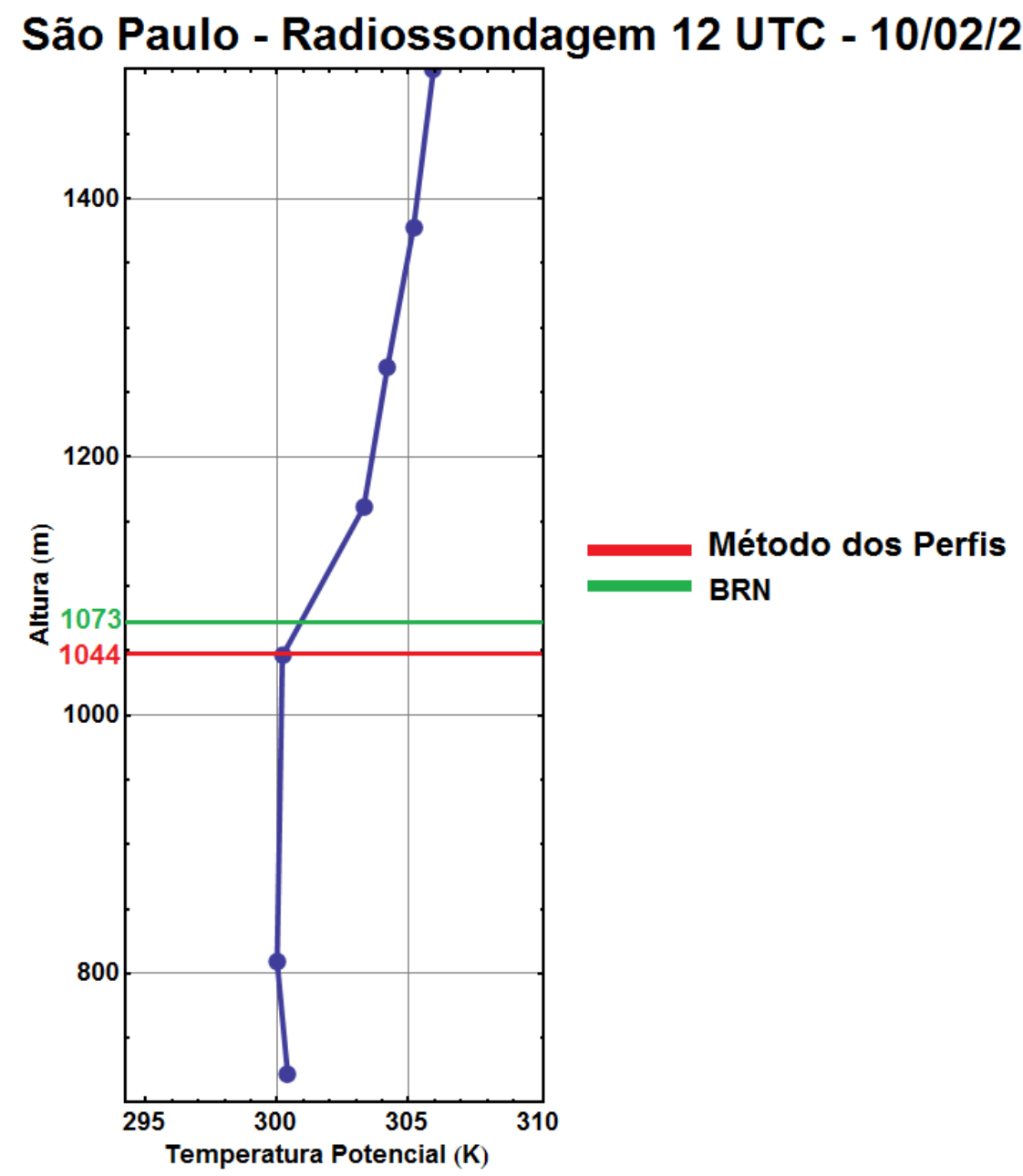

Figura 4.5: Comparação entre o BRN e o Método das Parcelas 
A principal dificuldade do método BRN consiste na escolha de $R_{S}$, o qual varia de acordo com a literatura, estando situado entre 0.25 - 0.30, valores estes obtidos experimentalmente [42, 51, 41, 46]. Neste trabalho $R_{S}$ será adotado como 0.25 [42].

Os Métodos para a obtenção da CLP, a partir de dados Lidar, podem ser divididos em três tipos principais:

- Métodos Limiares: Métodos deste tipo determinam o topo da CLP a partir de determinados pontos de altura que possuem uma intensidade de retroespalhamento com uma determinada fração superior a média encontrada na troposfera livre. A grande variabilidade natural da atmosfera torna difícil a determinação de um valor que permita, de forma clara e consistente, a realização da distinção entre a CLP e a Atmosfera Livre em todos os casos. Com isso a padronização de tais métodos, em torno de um determinado valor, torna-se um problema bastante complexo [26];

- Métodos Derivativos: Tais métodos consistem na busca por mudanças acentuadas ao longo do perfil Lidar, sendo isto possível por conta da grande variação existente entre as intensidades de retroespalhamento dentro e fora da CLP. Tais métodos apresentam dificuldades quando há camadas de partículas sobre ou abaixo da CLP, pois estas geralmente são bem definidas, e isto faz com que estes métodos geralmente identifiquem tais camadas como o topo da CLP [26].

- Métodos da Zona de Entranhamento: Estes são variações dos métodos limiares. A idéia principal é determinar o topo da CLP, conhecendo-se a extensão da Zona de Entranhamento [26].

Os métodos empregados neste trabalho são do tipo derivativos, com exceção do Método das Imagens. 


\subsubsection{Método do Gradiente (MG)}

Neste método a ideia é encontrar variações bruscas no perfil verical de condentração de uma substância traço, onde no caso do lidar a mudança procurada é referente aos aerossóis, uma vez que a concentração dos mesmos na CLP é muito superior a encontrada na atmosfera livre. Portanto o gradiente vertical da concentração entre o primeiro e o último ponto de medida da CLP, deve apresentar um valor negativo, se destacando dos obtidos anteriormente.

A partir da correção realizada nas equações 3.4 e 3.5, é possível encontrar a altura da CLP, fazendo a derivada do RCS(z):

$$
\frac{d}{d z} R C S(z) \quad 4.2
$$

E posteriormente encontrando o seu valor mínimo, o qual representará o topo da CLP [5, 15].

Uma outra forma de utilização deste método é a realização da derivada do logaritmo do sinal corrigido, ao invés da derivada simples:

$$
\frac{d}{d z} \log (R C S(z)) \quad 4.3
$$

e em seguida obter o valor mínimo da mesma. Esta aproximação geralmente fornece valores, para a altura da CLP, superiores aos da derivada simples [15].

A principal vantagem da utilização da derivada do $\log$ ao invés da derivada simples (equação 4.2) é que o coeficiente de extinção, mesmo sendo pequeno, apresentará uma forma linear gerando uma maior diferença entre os valores máximo e mínimo apresentados, deixando o mínimo mais acentuado(Fig. 4.6) [12].

Outra grande vantagem deste método possuir é a sua resolução temporal, a qual é a mesma do lidar.

As principais desvantagens na utilização da técnica do gradiente são:

- Ser sensível a ruídos: Técnicas baseadas na derivação de sinais em função 

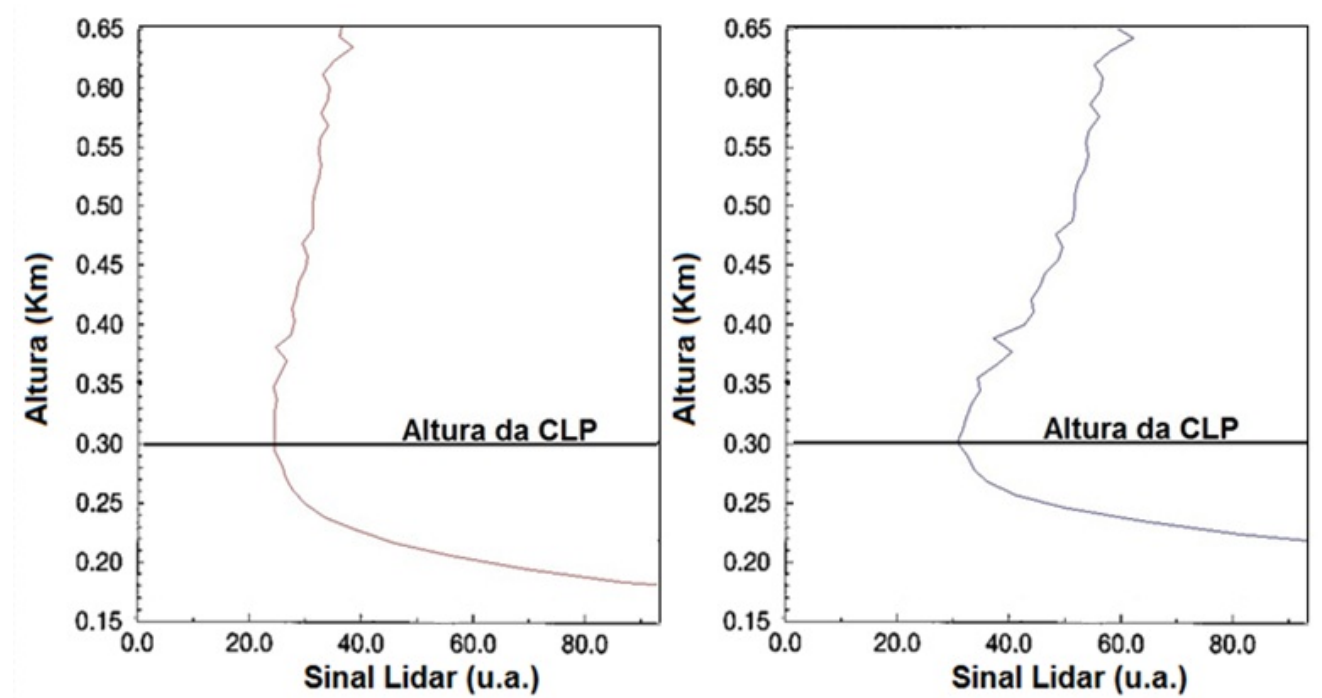

Figura 4.6: Comparação entre o perfil da Derivada Simples (Esq.) e o da Derivada do $\log ($ Dir.)

da altura $(d b / d z)$ podem ter ampliação no ruído do sinal, devido a diferenciação de dados que já possuem ruídos. Com isso o perfil resultante pode possuir tanto ruído que o valor procurado pode não ser apresentado de forma evidente [18, 44].

- Apresentar falhas quando há diversas subcamadas dentro da CLP, o que ocasiona a formação de vários mínimos locais, complicando a seleção do valor que corresponda apropriadamente ao topo da CLP [34].

- Sob condições de alta estabilidade na atmosfera (geralmente no período noturno), a baixa taxa de mudanças no topo da CLP, pode ocasionar a falha do método [4].

Neste trabalho foi utilizada a derivada do Logaritmo e implementada uma mudança em tal método, a inserção de um valor limiar, o qual funciona da seguinte maneira: são feitas várias iterações para o MG, sendo que ao realizar a busca pelo valor mínimo em cada uma das iterações há um valor limiar a ser ultrapassado, o qual inicia em 0 e vai até -1. Esta iteração foi aplicado por Baars [5] no método WCT para tentar facilitar a separação entre nuvens e subcamadas de aerossóis e a CLP, sendo aqui aplicada ao MG com o mesmo intuito. 


\subsubsection{Método da Covariância da Transformada de Wavelet (WCT)}

Nas últimas décadas [1], tem sido muito empregada a Transformada de Wavelet para o estudo de sinais. Tal técnica consiste basicamente na decomposição do sinal em vários níveis de resolução. Com isso, é possível realizar uma análise em função da escala e extrair diferentes informações apenas com a alteração da "janela" utilizada. Estas transformadas também permitem a obtenção de forma simultânea do tempo e da frequência. Por exemplo: é possível obter uma boa resolução temporal e uma baixa resolução de frequência, para eventos de alta frequência. $E$ uma boa resolução de frequência, com baixa ressolução temporal, para eventos de baixa frequência [52].

Estas características tornam a Transformada de Wavelet mais eficaz que as Transformadas de Fourier para Tempo Curto - (STFT - Short Time Fourier Transform), pois estas não permitem alterações na janela e são ineficientes para sinais nãoestacionários, pois quando há transformação no domínio da frequência, a informação é perdida [1, 23, 52].

As Transformadas de Wavelet se dividem em dois grupos Contínuas (CWT Continuous Wavelet Transform) e Discretas (DWT - Discret Wavelet Transform), sendo as últimas excelentes ferramentas para a decomposição e filtragem de séries temporais. Isto faz desta Transformada uma importante técnica para o estudo de variáveis atmosféricas, devido a natureza temporal dos sinais das mesmas.

Um método que têm sido muito utilizado recentemente [4, 7, 12] para encontrar a altura máxima da CLP é a Covariância da Transformada de Wavelet (WCT - Wavelet Covariance Transform), a qual consiste na detecção das mudanças de passo do sinal, mediante a realização da covariância de um Wavelet com o sinal corrigido do Lidar. Sendo necessário que a função escolhida possua caracterísicas semelhantes as do sinal analisado. Para o caso do Lidar uma das mais indicadas é uma DWT, a função de Haar [52](Fig. 4.7):

$$
h\left(\frac{z-b}{a}\right)=\left\{\begin{array}{c}
-1: b-\frac{a}{2} \leq z \leq b \\
1: b \leq z \leq b+\frac{a}{2} \\
0: \text { Outros Casos }
\end{array}\right.
$$


onde: $b$ é a translação vertical da função, $a$ é a dilatação da função e $z$ é a altura.
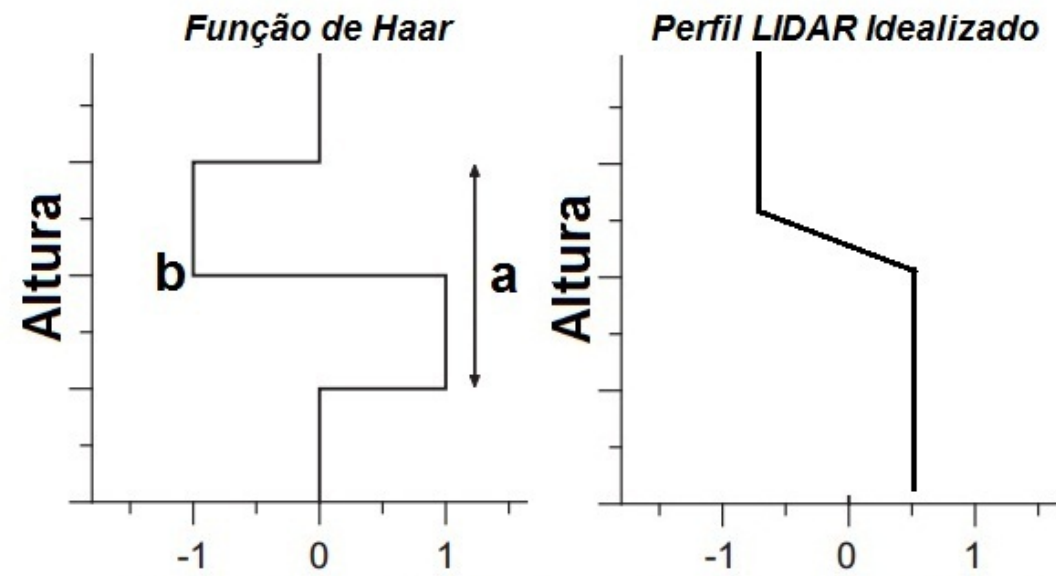

Intensidade do Sinal Intensidade do Sinal

Figura 4.7: Comparação entre a Função de Haar e o Perfil Lidar Idealizado

A covariância possui a seguinte forma:

$$
W_{f}(a, b)=\frac{1}{a} \int_{z_{b}}^{z_{t}} f(z) h\left(\frac{z-b}{a}\right) d z
$$

onde temos que: $W_{f}(a, b)$ é a WCT, $f(z)$ é o sinal lidar corrigido (RCS) a uma determinada altura $z$ e, $z_{b}$ e $z_{t}$ são os limites da parte baixa e alta do perfil, respectivamente.

A função WCT terá o seu máximo no ponto onde o valor de $b$ corresponder a altura onde ocorre uma abrupta mudança no sinal Lidar, a qual é oriunda de uma grande alteração na concentração de aerossóis. Isto indica a passagem da CLP para a atmosfera livre, visto que a última possui uma menor concentração de aerossóis quando comparada a primeira. Portanto tal ponto é indicado como a altura máxima da CLP [5].

As principais vantagens deste método são:

- Apresenta bons resultados sobre muitas situações meteorológicas, além de ser válido para todas as estações do ano [5];

- É menos afetado por ruídos do que outros métodos, e portanto, robusto mesmo em situações onde há muito ruído [5]; 
- Resolução temporal igual a do Lidar;

- Pode ser facilmente automatizado, para uma detecção contínua da CLP [5];

A grande dificuldade do método WCT consiste na determinação do parâmetro $a$, o qual é muito variável e depende fortemente das características atmosféricas [5, 7. 15]. Influenciar diretamente os gradientes verticais no retroespalhamento Lidar, e dificultando a identificação do topo da CLP.

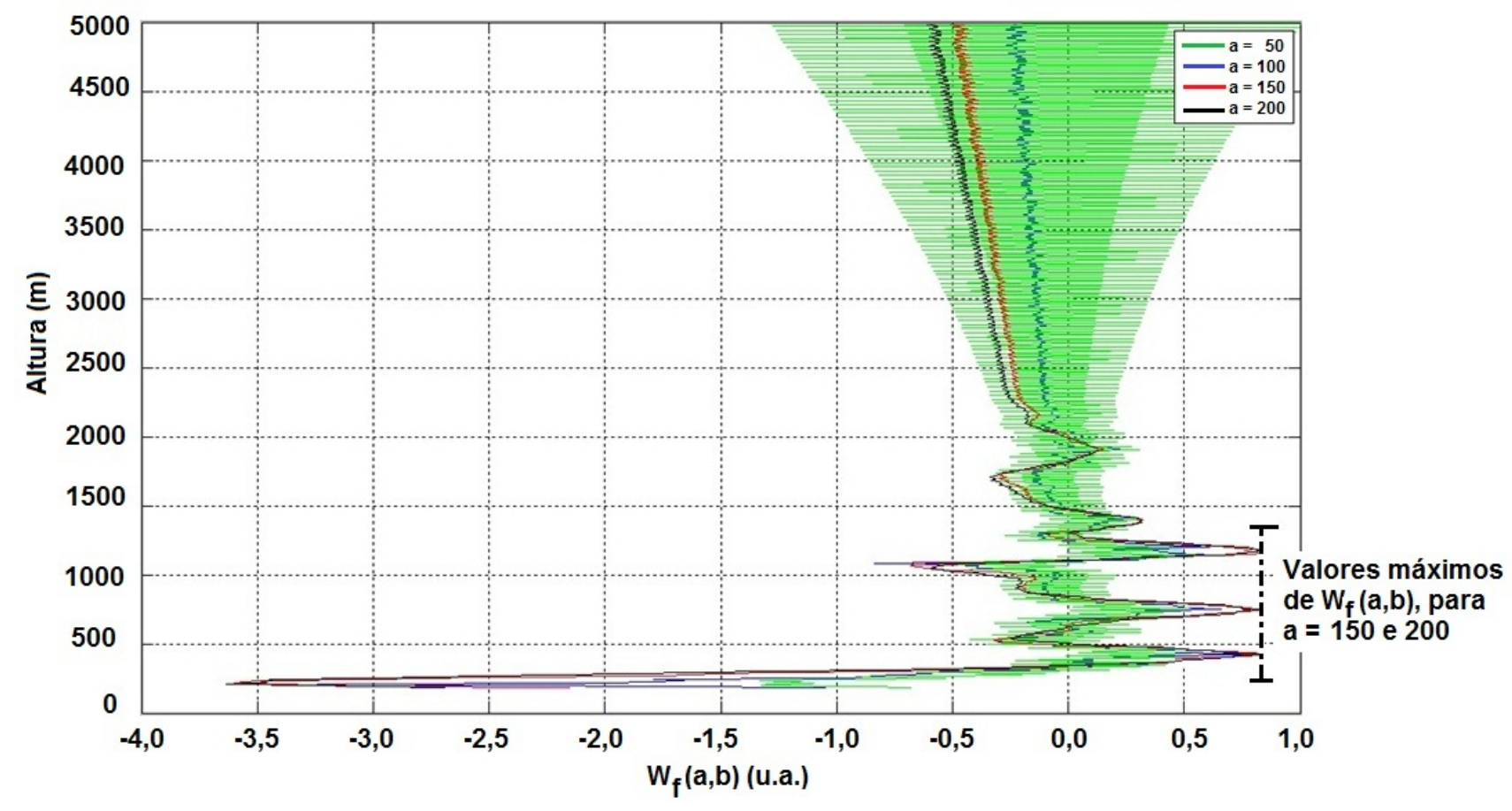

Figura 4.8: Perfil da WCT com variações no Parâmetro a

Para os dias de calmaria, sem a presença de nuvens e/ou camadas espessas de aerossóis, a escolha do parâmetro a não é crucial, bastando apenas que ele seja grande o suficiente para permitir a vizualização da diferença de sinal na zona de transição e assim possibilitar a identificação do topo da CLP. Porém quando há presença de nuvens e/ou camadas espessas de aerossóis, como por exemplo em casos de desenvolvimento de uma camada de nuvens ou camada residual, uma correta seleção do parâmetro $a$ se torna fundamental para a obtenção de um bom resultado [34].

A Figura 4.8 ilustra bem estas dificuldades para um dia com presença de camadas com altas concentrações de aerossóis. Para baixos valores de $a(a=50)$ o perfil se 
torna muito ruidoso e, para valores altos $a=150$ e $a=200$ há três picos com valores máximos para alturas diferentes. Ou seja, a escolha de um valor adequado para o parâmetro $a$ é o maior desafio na utilização do método WCT [15, 5, 7].

Para este método, assim como no MG, foi utilizada a inserção de um valor limiar para realizar a separação entre nuvens, subcamadas de aerossol e a CLP, o qual ao longo das diversas iterações, varia de 0 a 1 .

\subsubsection{Método da Variância}

Este algoritmo consiste em obter a variância do sinal lidar corrigido $(R C S(z))$ a partir da Equação 4.6, onde o ponto em que houver máxima variância, será adotado como topo da CLP [20].

$$
\operatorname{Var}(z)=\frac{1}{z} \sum_{z=1}^{K}((R C S(z))-\overline{R C S}) \quad 4.6
$$

onde $K$ é o número total de perfis lidar e $\bar{P}$ é a média dos sinais lidar corrigidos. Este método possui a mesma resolução temporal do Lidar.

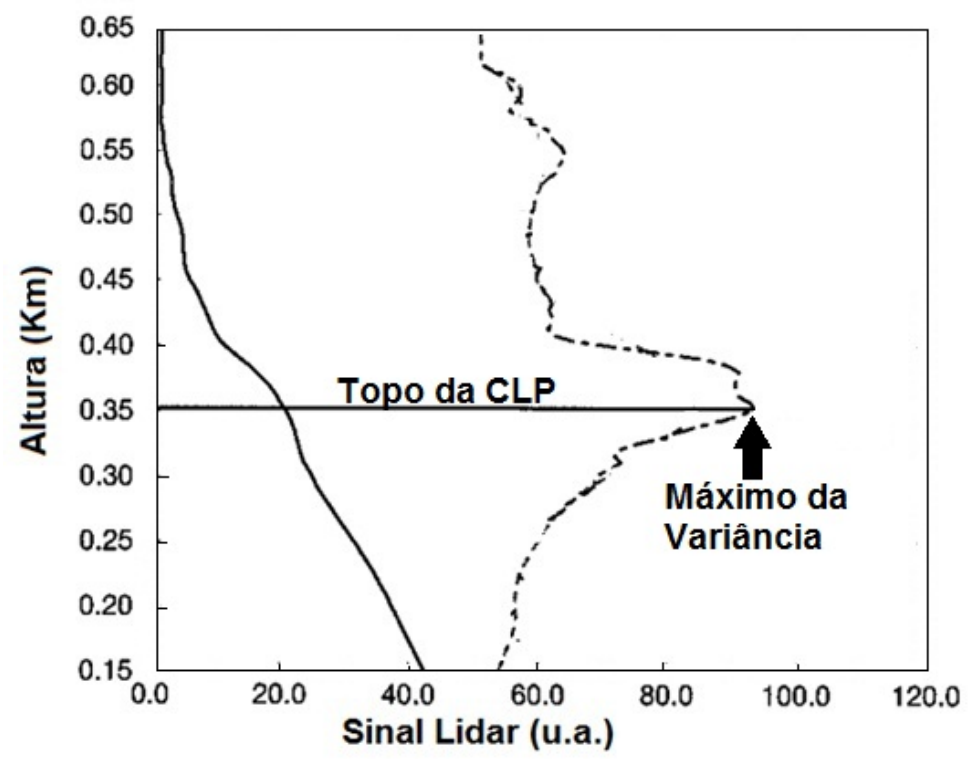

Figura 4.9: Comparação entre as imagens antes e depois da aplicação do filtro

A Fig. 4.9 mostra o perfil lidar (linha contínua) em comparação com a função gerada a partir do método da Variância (linha pontilhada). O ponto máximo da 
variância é indicado por $h_{v c m}$, o qual corresponde ao topo da CLP [20].

A principal vantagem deste método é possuir uma resolução temporal próxima a do Lidar, variando em função do tamanho do grupo de pontos. A maior desvantagem fica por conta da utilização deste método em situações de baixa concentração de aerossóis, pois a baixa variabilidade do sinal prejudica a detecção do topo da CLP.

\subsubsection{Método das Imagens}

Este algoritmo foi desenvolvido pelo próprio grupo de pesquisa, e não se enquadra na categora de métodos derivativos. O mesmo consiste em uma rotina desenvolvida no programa Mathematica, a qual possibilita a identificação da altura máxima da CLP mediante a utilização de um gráfico cortina a partir de uma figura, gerada por um programa da Raymetrics, do perfil Lidar com variação temporal.

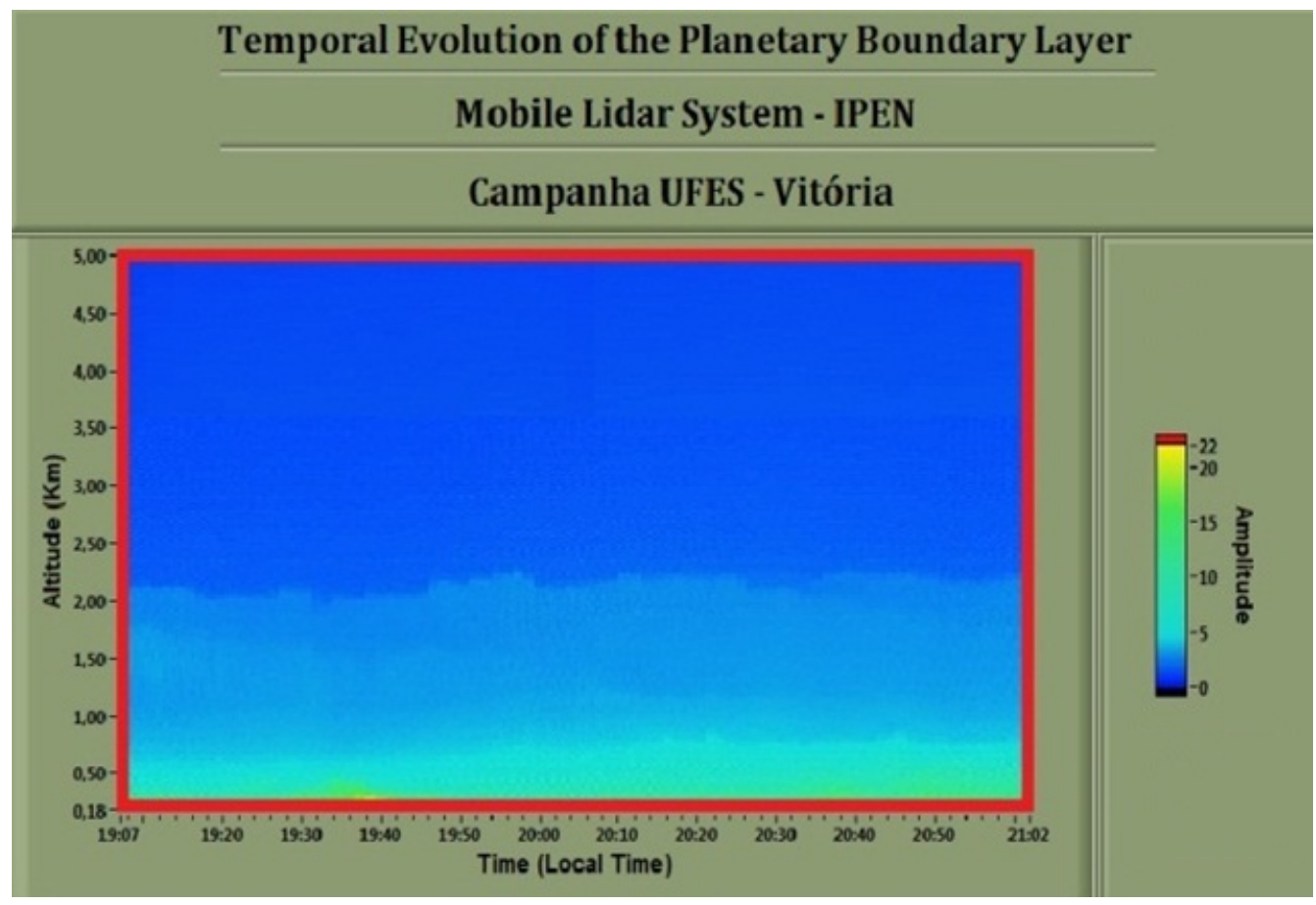

Figura 4.10: Gráfico cortina gerado pelo LabView a partir de dados lidar

Dada a diferença existente na concentração de aerossóis entre a CLP e a atmosfera livre, tomando-se um gráfico do perfil de concentração vertical da atmosfera, é possível, graças a diferença de cores, identificar os pontos de maior concentração e assim estimar valores para os pontos mais altos da CLP. Sendo tal método similar 
a análise visual do perfil, porém a automatização permite uma obtenção mais precisa dos valores de altura.

O primeiro passo é a realização da extração da região demarcada por uma quadrado vermelho na Fig. 4.10 e aplicação do Filtro de Solarização do software Mathematica. Tal filtro tem a propriedade de realizar a inversão de tonalidades, ou seja, as áreas escuras se tornam claras e vice-versa. Com isso é gerado um maior contraste na imagem e a camada limite se torna mais visível (Fig. 4.11).

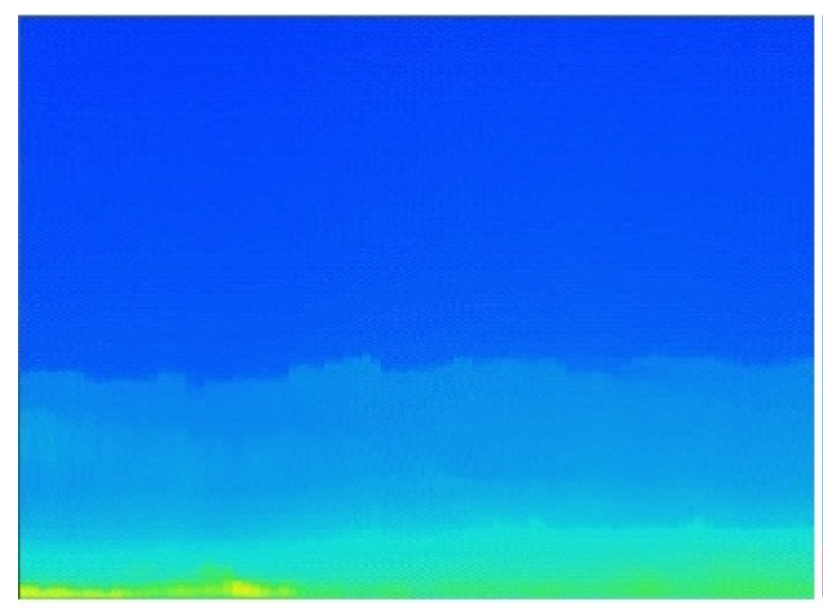

Antes

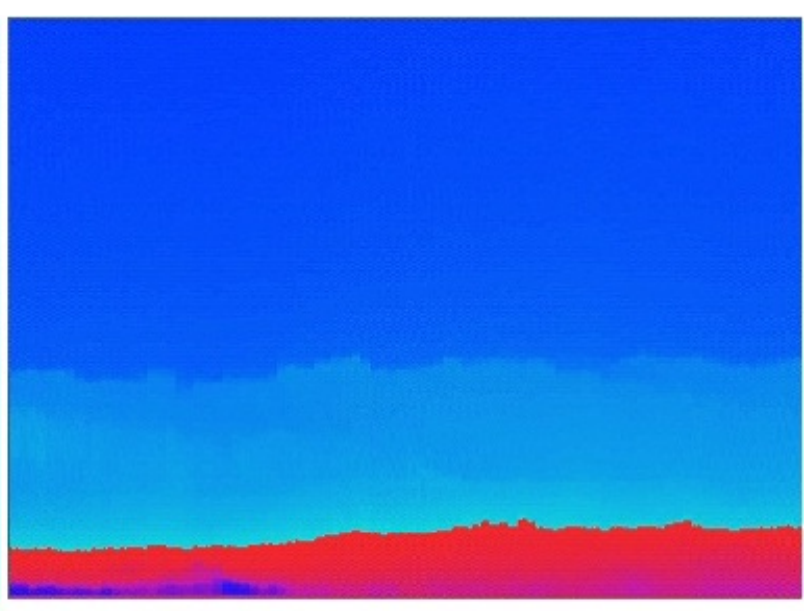

Depois

Figura 4.11: Figura antes da aplicação do filtro de Solarização (Esq.) e após a aplicação do mesmo (Dir.)

Em seguida, é realizada a separação das cores da palheta RGB, sendo aplicado o filtro Edge Detect, do software Mathematica, sobre a cor vermelha, já que esta preenche toda a área relativa a CLP. Com isso é possível obetr o contorno do topo da camada, como mostra a Fig. 4.12.

O próximo passo é aplicar na imagem obtida uma função do software Mathematica denominada Imageldentify, a qual é capaz de identificar pontos semelhantes dentro de uma figura (mediante a utilização do Filtro de Canny) e retornar as suas coordenadas (Figura 4.13). Após a obtenção de tais valores, é feita a média móvel para o conjunto de pontos do eixo y, os quais corresponderão as alturas da camada ao longo do perfil.

Por fim, a partir do tamanho da imagem, é obtida a quantidade de pixels que a mesma possui, sendo que com tal valor é possível normalizar a média móvel e obter a altura do topo da CLP (Fig. 4.14). Devido a realização das médias, este método 


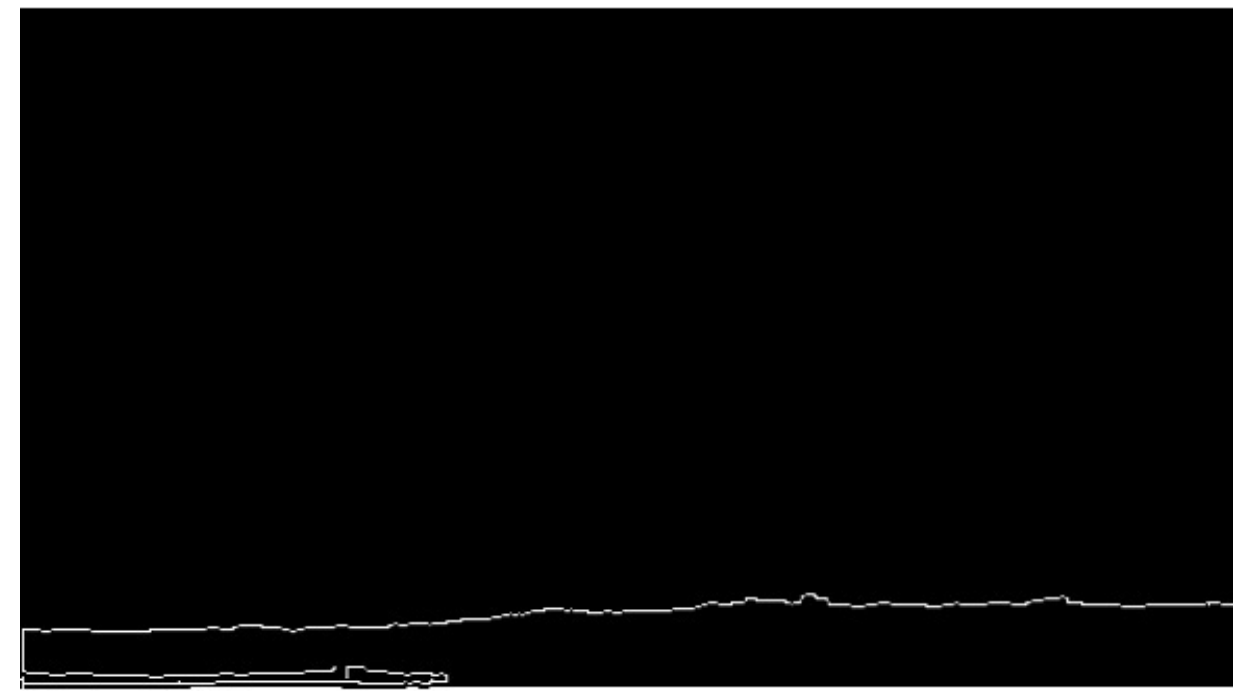

Figura 4.12: Imagem após a aplicação do Filtro Edge Detect

possui uma resolução temporal cerca de 20 vezes inferior a do Lidar. 


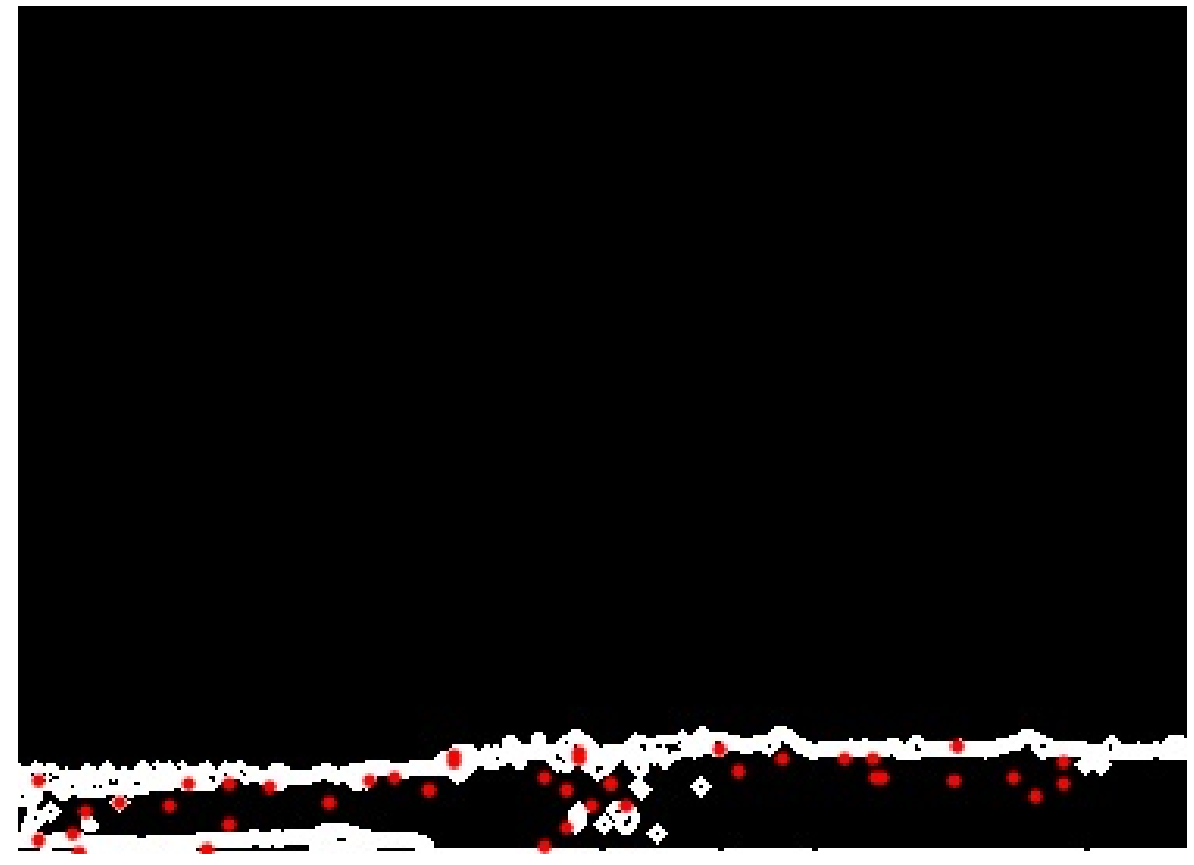

Figura 4.13: Imagem após aplicação do Filtro de Canny

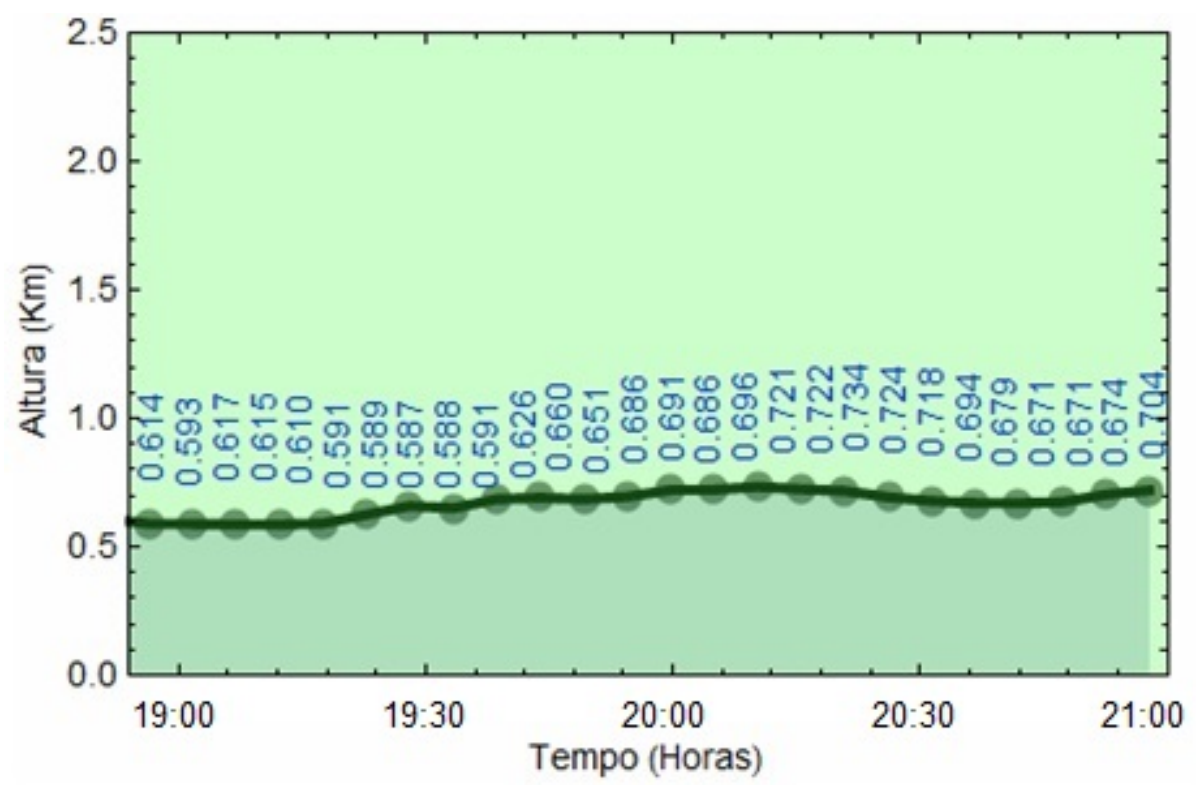

Figura 4.14: Resultado do Método das Imagens 


\section{Capítulo 5}

\section{Resultados e Discussões}

Neste capítulo serão apresentados os resultados e, será realizada uma discussão sobre os mesmos. A análise de dados foi divida em duas partes principais, sendo a primeira um Estudo de Casos (relativo a campanha de Vitória), o qual foi subdividido em três situações ${ }^{3}$ : "calmaria", presença de subcamadas de aerossóis e/ou camadas de nuvens e "turbulência". A segunda parte é referente a uma medida realizada ao longo de 12 horas contínuas na campanha MCITY-SP.

Serão adotados como altura padrão para a CLP as oriundas de: análise visual do perfil Lidar, lembrando que tal região possui uma concentração de aerossóis superior a da atmosfera livre; e os valores obtidos a partir do BRN, pois embora representem de um a dois pontos ao longo do perfil (devido a quantidade de lançamentos das radiossondas), eles permitem mais uma forma de comparação já que são oriundos de outra fonte de dados (Radiossondagem). Nos gráficos em que é exibida a comparação entre os métodos e o BRN, são apresentadas as barras de erros dos métodos, afim de possibilitar uma melhor vizualização da região de abrangência dos mesmos. $\mathrm{Na}$ segunda parte da análise também haverá comparação com o modelo WRF.

${ }^{3}$ As situações meteorológicas foram caracterizadas mediante análise visual e dados de sodar (Apêndice A) 


\subsection{Estudo de Casos}

\subsubsection{Situação de 'Calmaria'}

Esta medida foi realizada na cidade de Vitória - ES no dia 25 de julho de 2012 das 11:30 horas até as 17:10 horas. Neste período a atmosfera apresentou baixa intensidade de ventos e nenhuma nuvem na região correspondente a CLP, a qual por sua vez mostrou-se bem definida e com poucas oscilações na altura (Fig. 5.1).

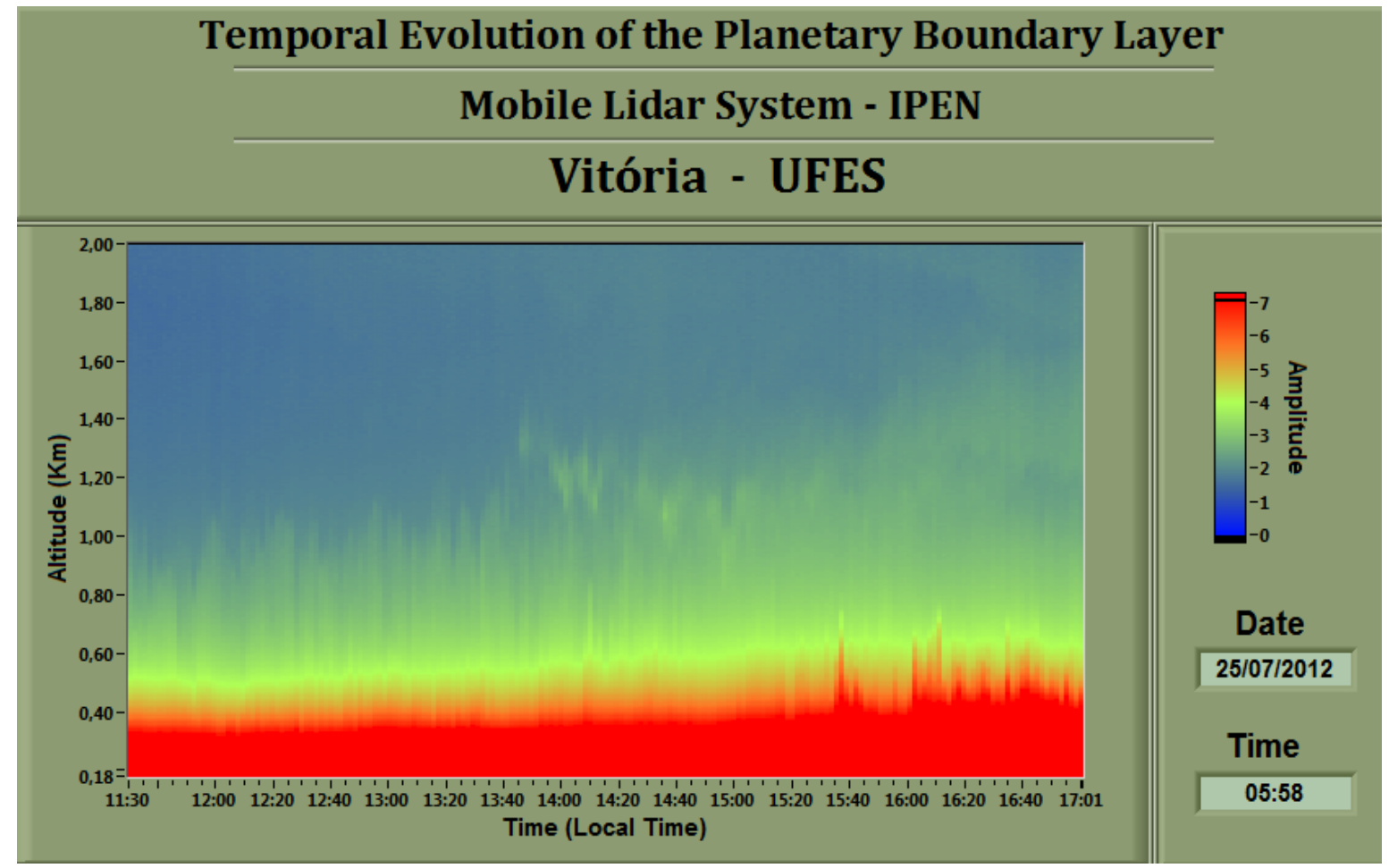

Figura 5.1: Perfil lidar para um dia de Calmaria 


\subsubsection{Método da Variância aplicado a situação de 'Calmaria'}

A Fig. 5.2 mostra o resultado obtido a partir da utilização do método da Variância. Foi utilizado um conjunto de 30 perfis para a realização do método e em seguida foi utilizada a média móve $4^{4}$ para cada conjunto de 15 pontos. Com isto a resolução temporal da curva gerada tornou-se 10 vezes inferior a do Lidar.

Este método não apresenta bons resultados, assim como afirma a literatura [15], pois para dias onde há baixas oscilações na altura e na concentração de aerossóis na CLP, há reduzida alternância entre os valores de sinal Lidar (Fig. 5.2). É possível observar que no período entre 13 e 16 horas a curva gerada a partir do método da Variância apresenta um grande pico, o que não condiz com o esperado.

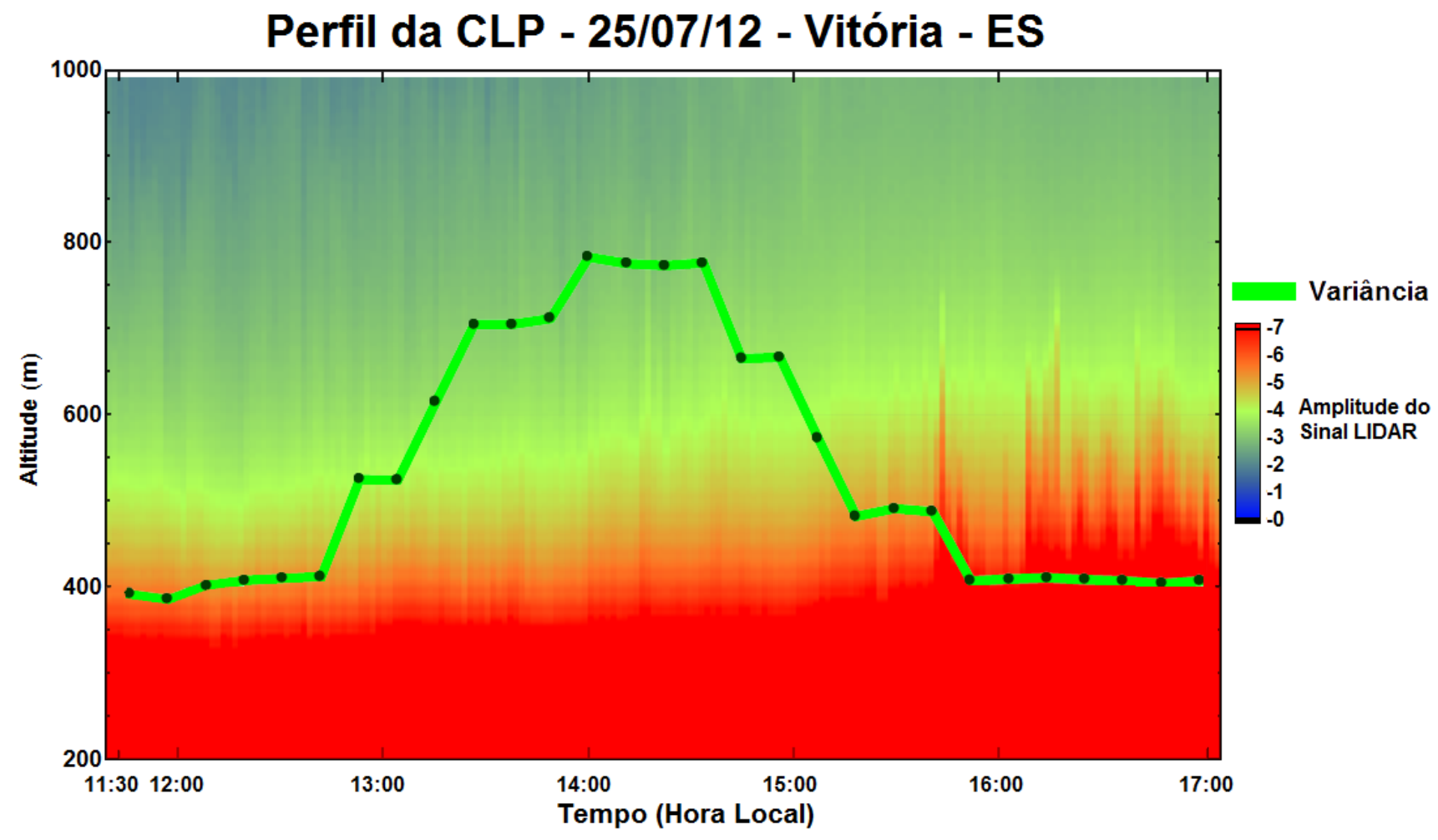

Figura 5.2: Método da Variância

A Fig. 5.3 mostra a comparação entre os resultados apresentados pelo método da Variância e o BRN5. Embora a Variância apresente uma grande divergência dos valores esperados, a mesma se aproxima do BRN em dois instantes.

\footnotetext{
${ }^{4}$ Apêndice B.2

${ }^{5}$ Apêndice B.1
} 


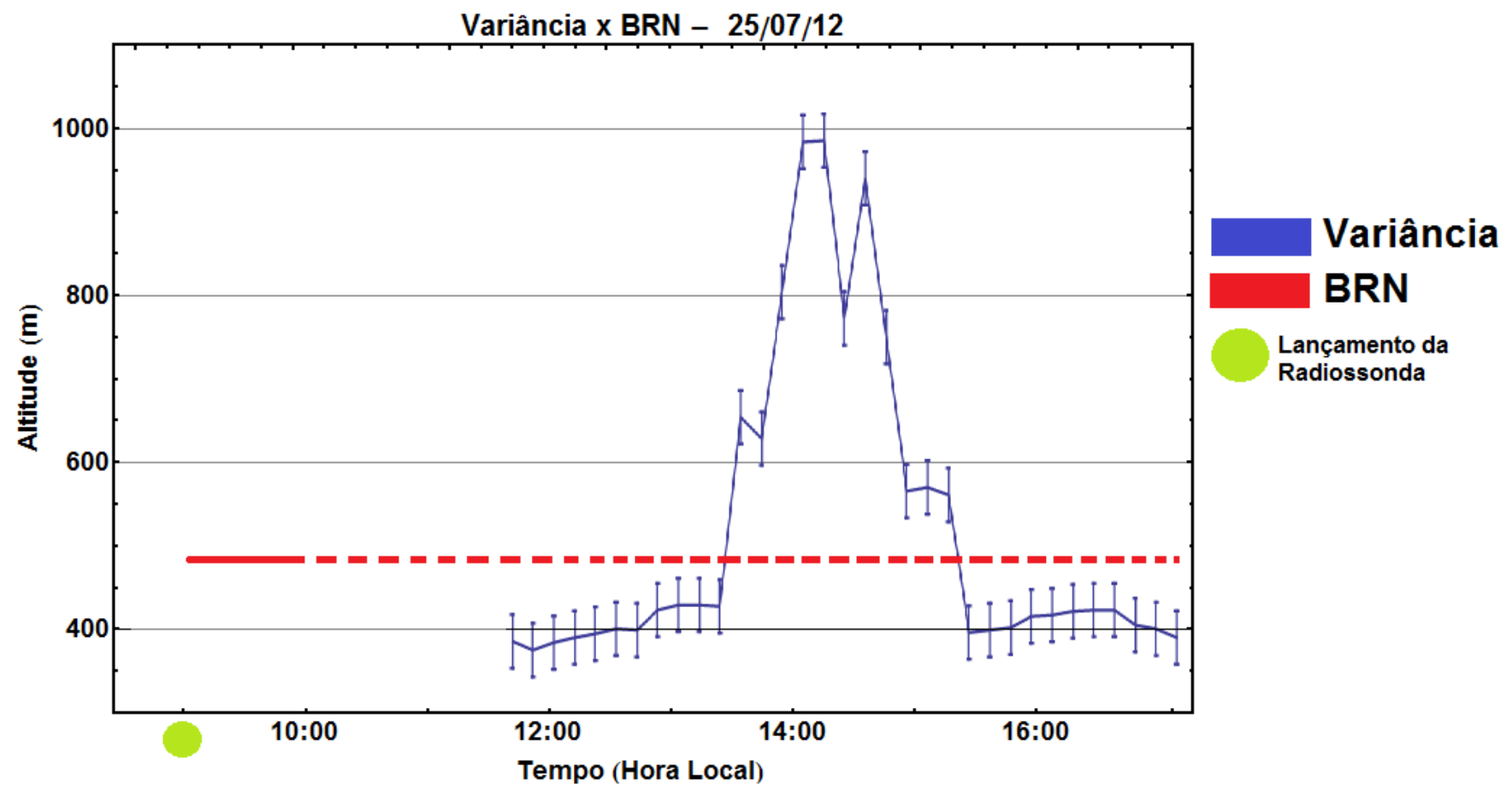

Figura 5.3: Comparação entre o Método da Variância e o BRN 


\subsubsection{Método das Imagens aplicado a situação de 'Calmaria'}

Na Fig. 5.4 são apresentados os resultados relativos ao método das Imagens. Foi utilizada a média móvel para cada conjunto de 5 pontos, com isso a resolução temporal tornou-se cerca de 20 vezes inferior a apresentada pelo Lidar.

Tal método representa muito bem o perfil da CLP, mostrando poucas oscilações e também uma baixa diferença (cerca de $35 \mathrm{~m}$ ) com relação aos valores obtidos a partir do BRN (Fig. 5.5). Para tal situação este método se mostra eficiente, devido ao seu baixo tempo de processamento e resultado condizente.

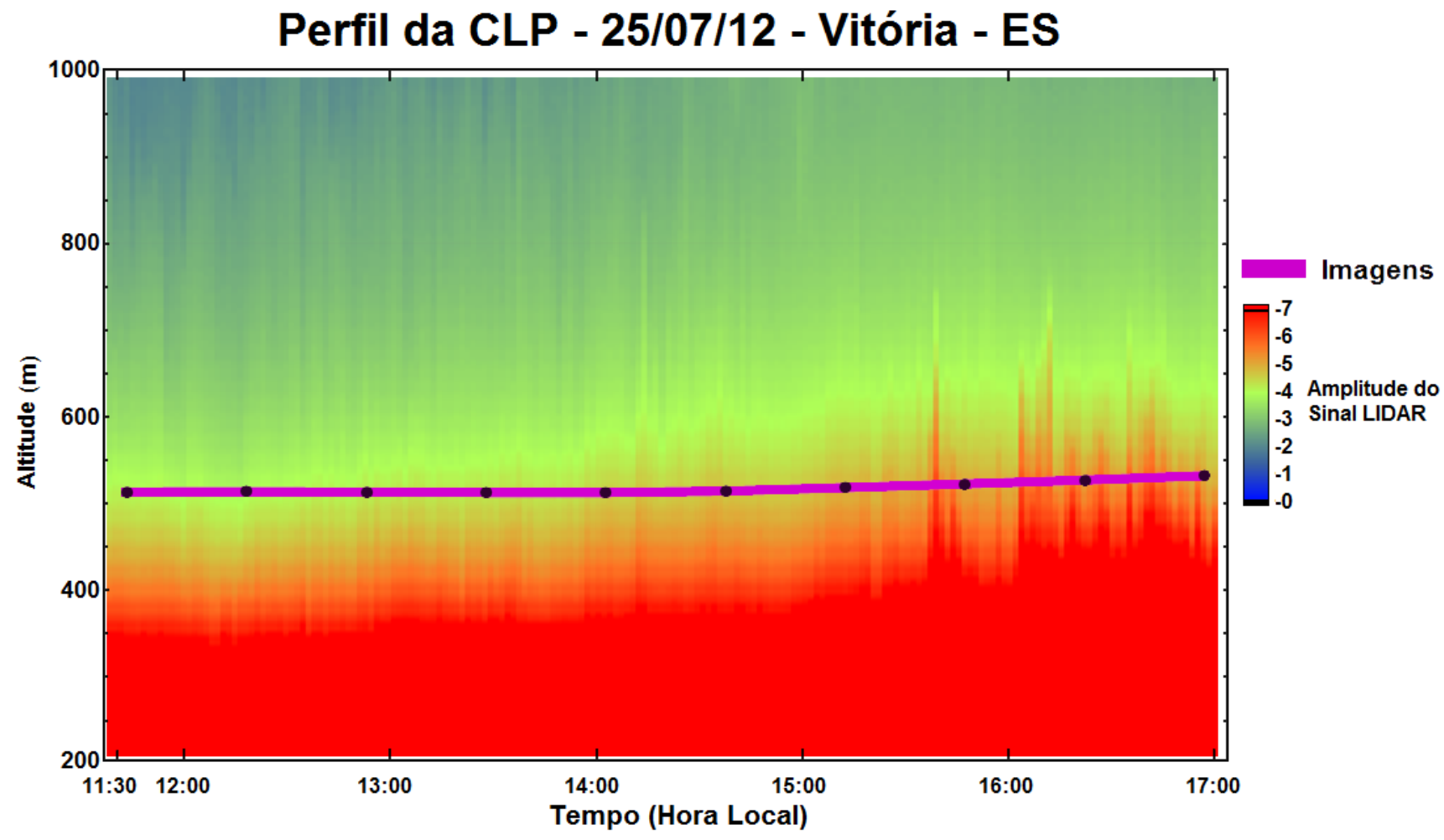

Figura 5.4: Método das Imagens 


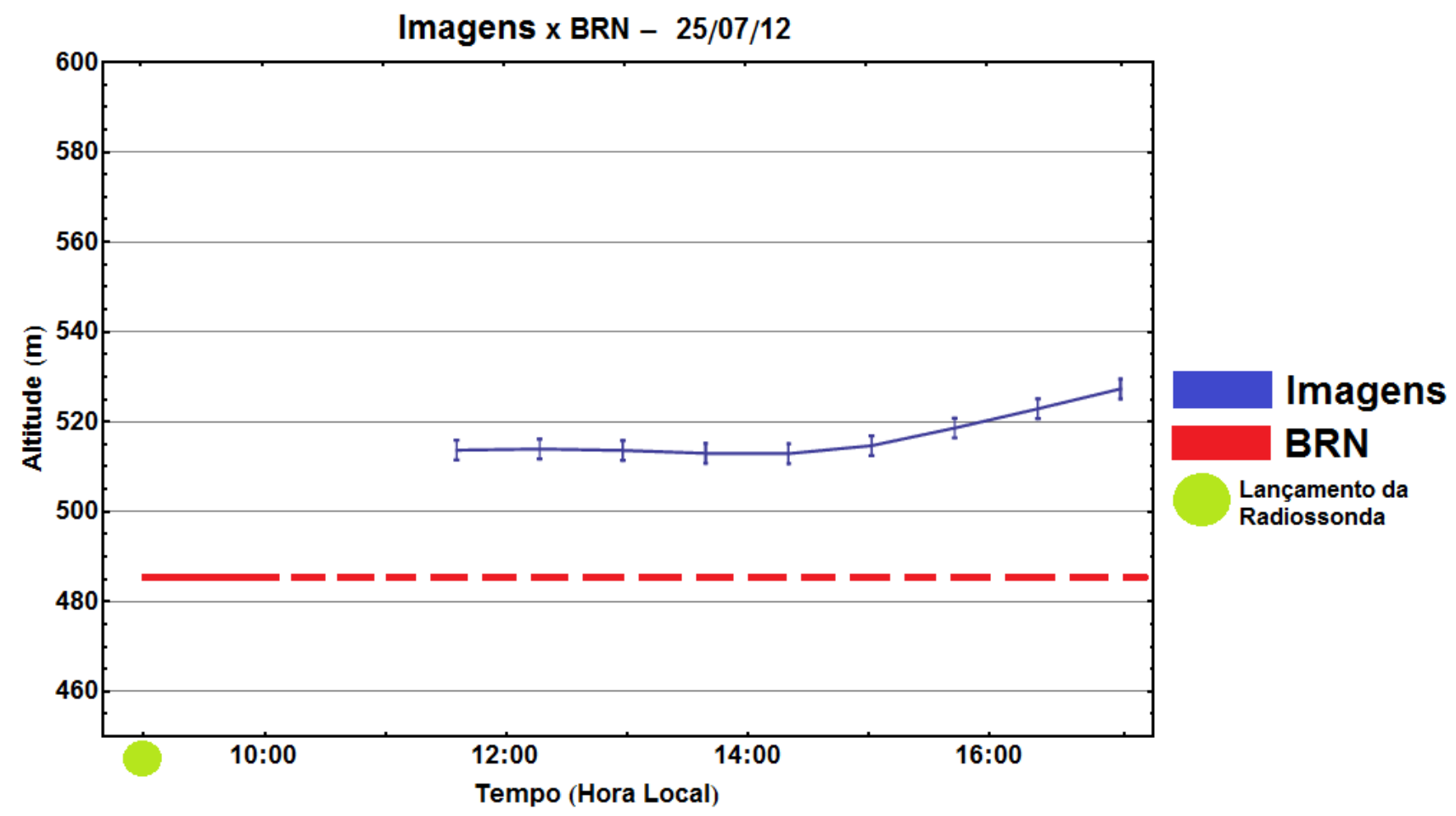

Figura 5.5: Comparação entre o Método das Imagens e o BRN 


\subsubsection{Método do Gradiente aplicado a situação de 'Calmaria'}

A Fig. 5.6 representa um perfil lidar individual que recebeu a aplicação da técnica do MG. É possível observar a presença de um mínimo bem definido, o que facilita a detecção do topo da CLP.

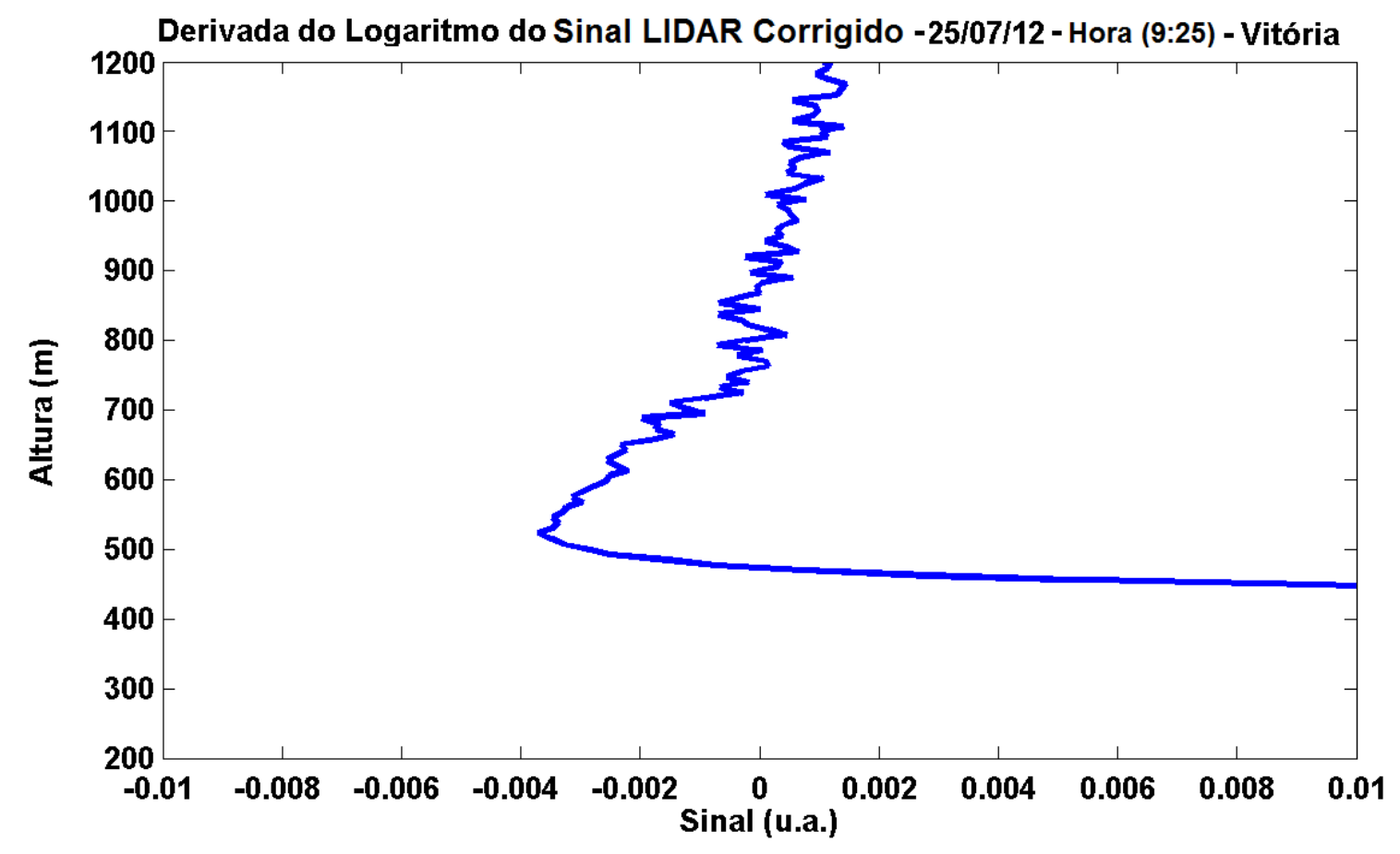

Figura 5.6: Perfil Individual obtido a partir do Método do Gradiente

Na Fig. 5.7 são exibidos três exemplos de valores limiares $(0,-0,4$ e $-0,9)$, onde o mínimo da função é adotado como o primeiro ponto inferior ao limiar. Embora o perfil da atmosfera seja simples, surgem diferenças de altura para os três valores de limiar utilizados. Outro contraste surge por volta das 15:50 horas, quando ocorrem pequenas oscilações na CLP, as quais, devido a sensibilidade do MG, geram uma elevação, que é mais acentuada para altos limiares do que para baixos.

A resolução temporal do método é igual a do Lidar, uma vez que é realizada um iteração para cada perfil, porém para as curvas finais foi utilizada a média móvel para cada conjunto de 60 pontos, dando ao perfil final uma resolução 4 vezes inferior a do Lidar. A Fig. 5.8 mostra a curva obtida a partir do MG para um limiar $=-0,4$, sendo este o valor que permite a obtenção do perfil mais próximo do valor esperado.

Na Fig. 5.9 é possível observar que, com exceção do trecho final do gráfico, onde 
MG - Altura da CLP - 25/07/12

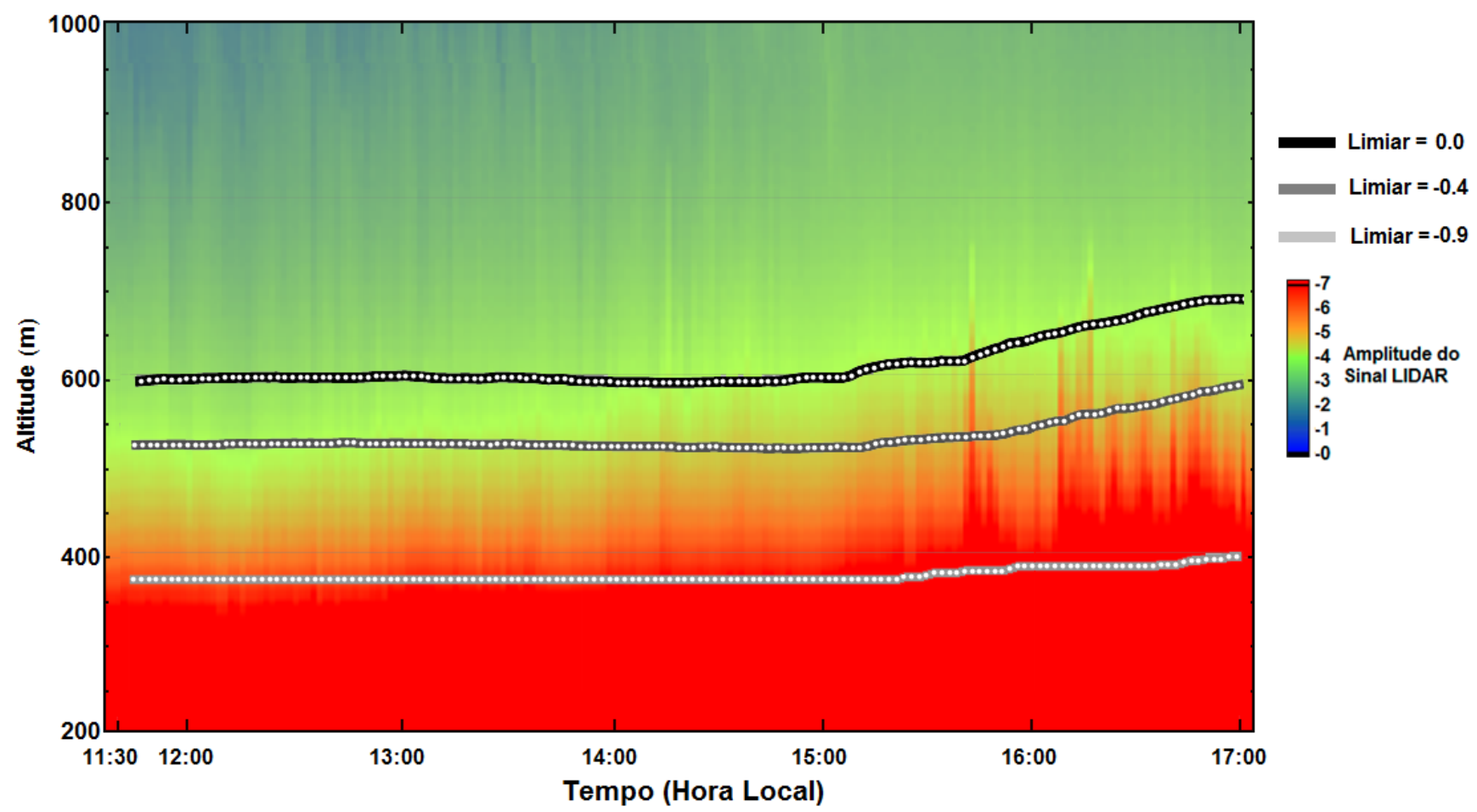

Figura 5.7: Método do Gradiente com variação de Limiar

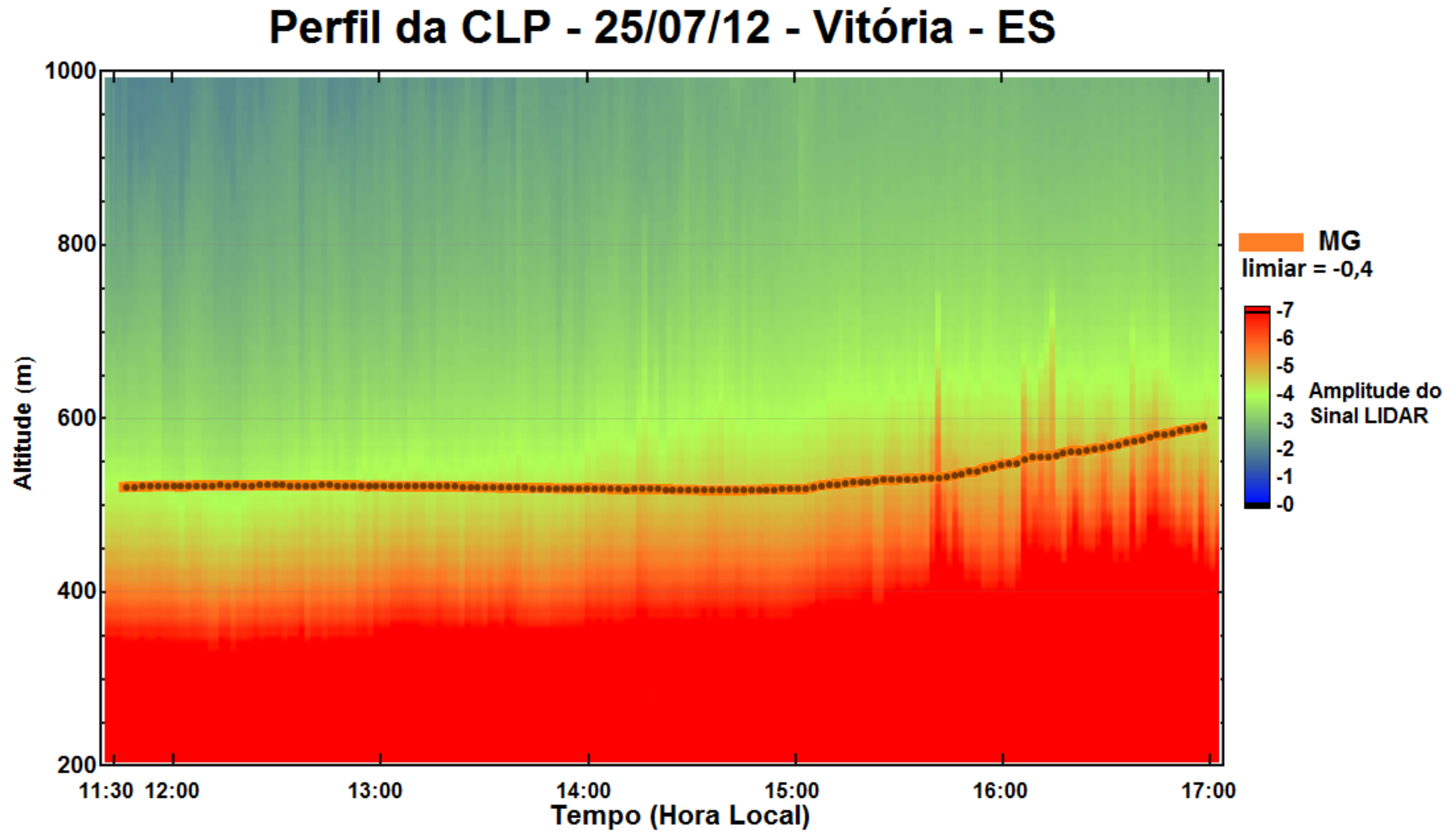

Figura 5.8: Método do Gradiente

a curva gerada pelo método começa a subir, o mesmo apresenta uma distância média de aproximadamente $35 \mathrm{~m}$ com relação ao BRN. 


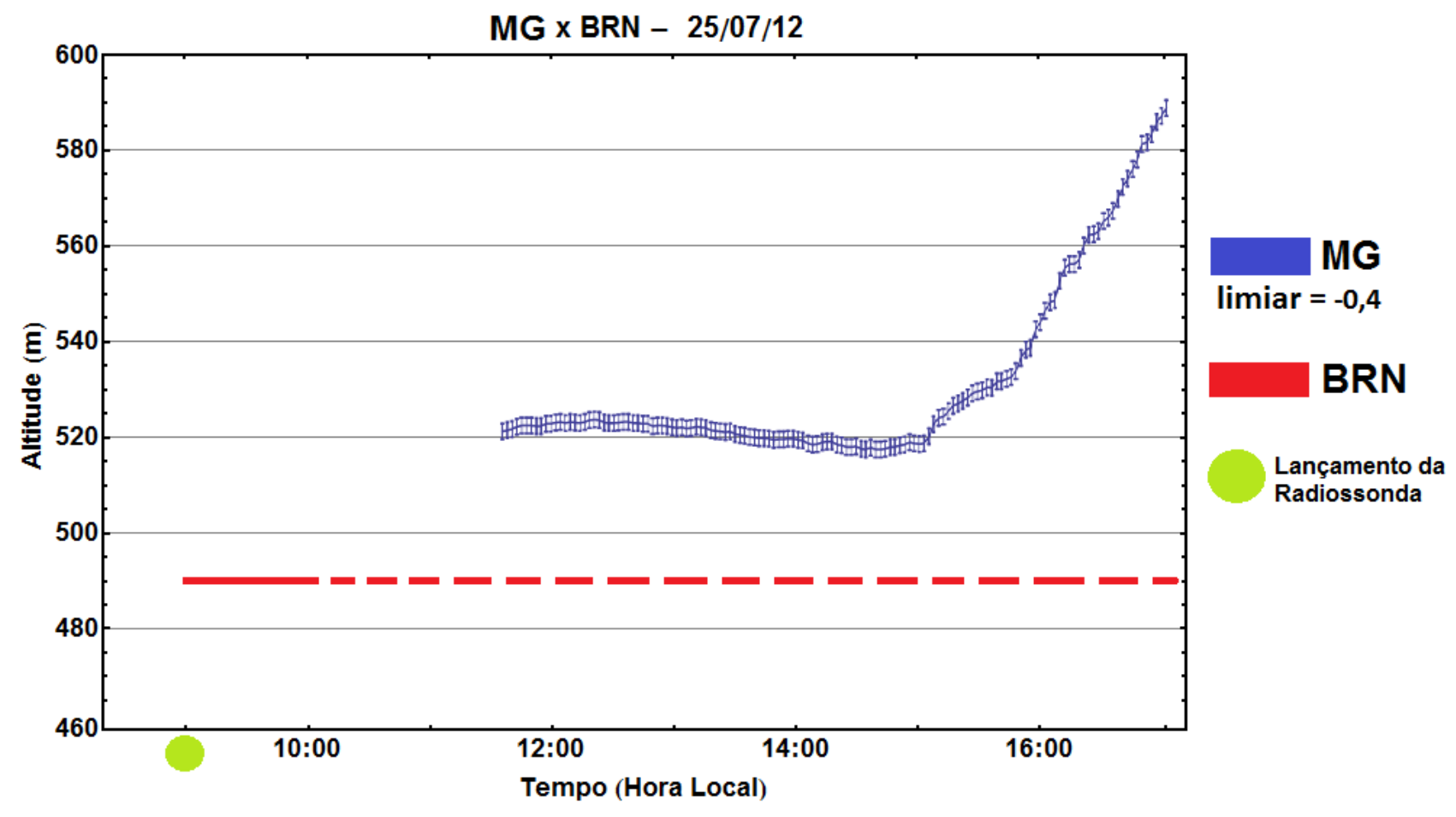

Figura 5.9: Comparação entre o Método do Gradiente e o BRN 


\subsubsection{Método Wavelet Covariance Transform aplicado a situação de 'Calmaria'}

Para um dia de calmaria, a aplicação do WCT em um perfil Lidar individual possibilita a identificação de um máximo bem definido (Fig. 5.10), o que facilita a detecção da altura máxima da CLP por tal método. Assim como no caso do MG, também foi inserido um limiar, porém variando de 0 a 0,9 , onde o primeiro ponto após o limiar é considerado o topo da CLP. A utilização deste recurso foi fundamental para a obtenção de um melhor resultado (Fig. 5.11).

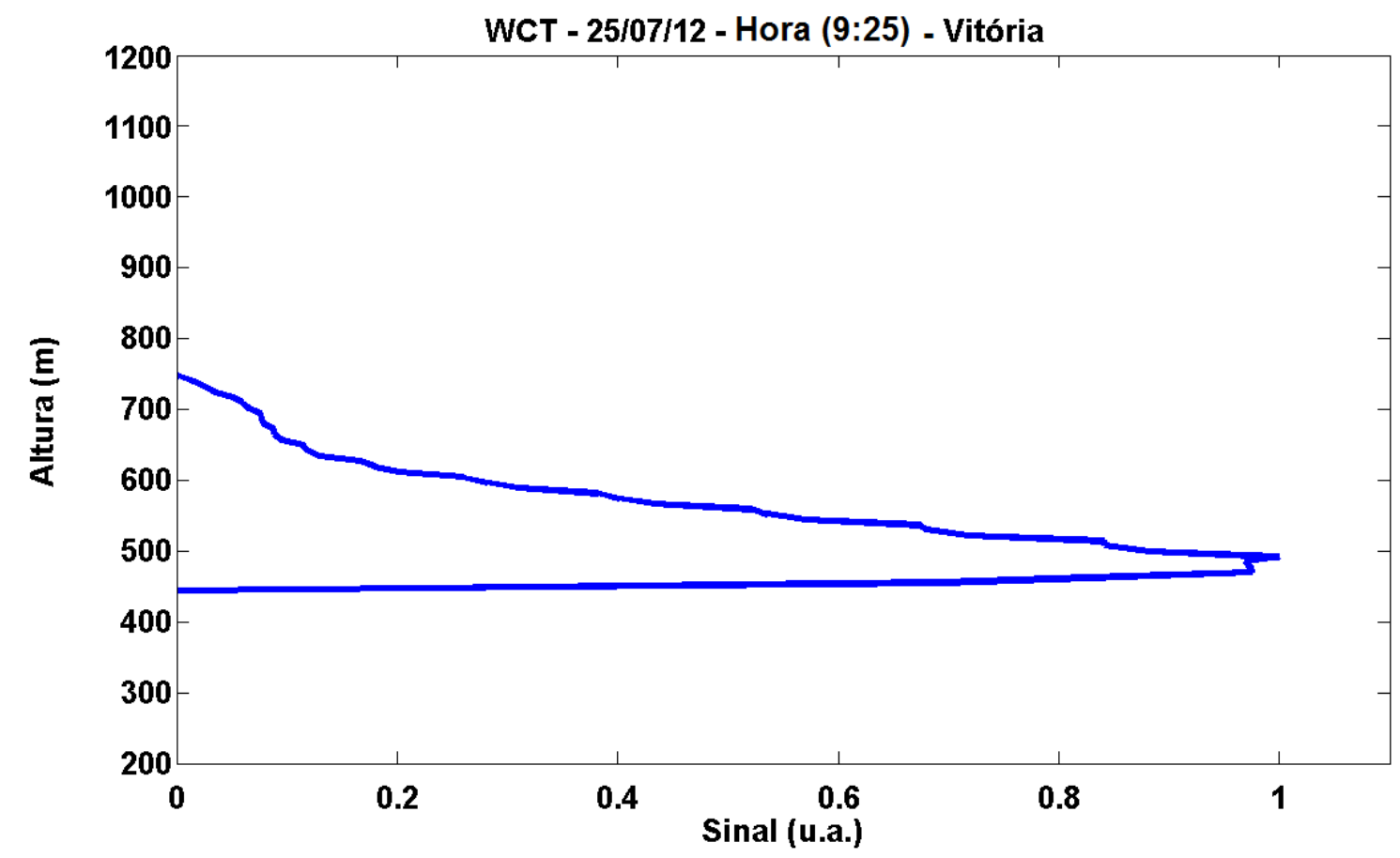

Figura 5.10: Perfil Individual obtido a partir do Método WCT

A maior dificuldade do método é encontrar os valores ideais para a e $b$, e para solucionar tal problema, foram realizadas diversas iterações de forma a gerar a melhor combinação possível. No entanto não houve uma diferença muito significativa para as variações de $b$ devido a simplicidade do perfil (Fig. 5.12), portanto foi adotado o menor valor a fim de obter um melhor detalhamento da função. Ocorrendo o mesmo para o parâmetro a (Fig. 5.13).

A Fig. 5.14 mostra a curva gerada pelo WCT com $a=50, b=10$ e limiar $=0,4$. Foi realizada a média móvel para cada conjunto de 60 pontos, o que dá a figura final uma 


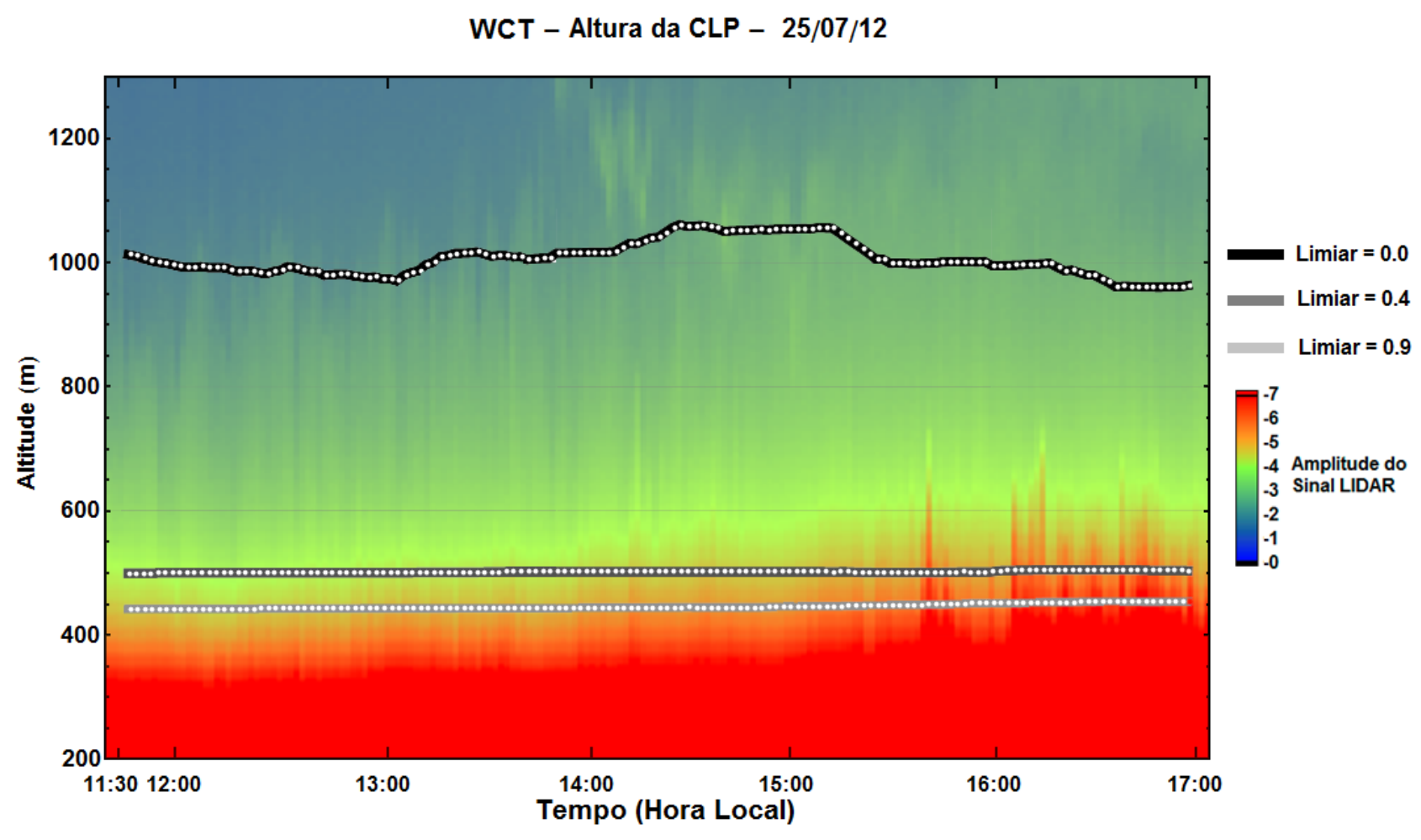

Figura 5.11: Método WCT com variação de limiar

resolução temporal 4 vezes inferior a do Lidar.

Na Fig. 5.15 é possível observar que as distâncias entre a curva gerada pelo WCT e o BRN são inferiores a $20 \mathrm{~m}$, sendo portanto o resultado mais próximo dentre todos os métodos. 


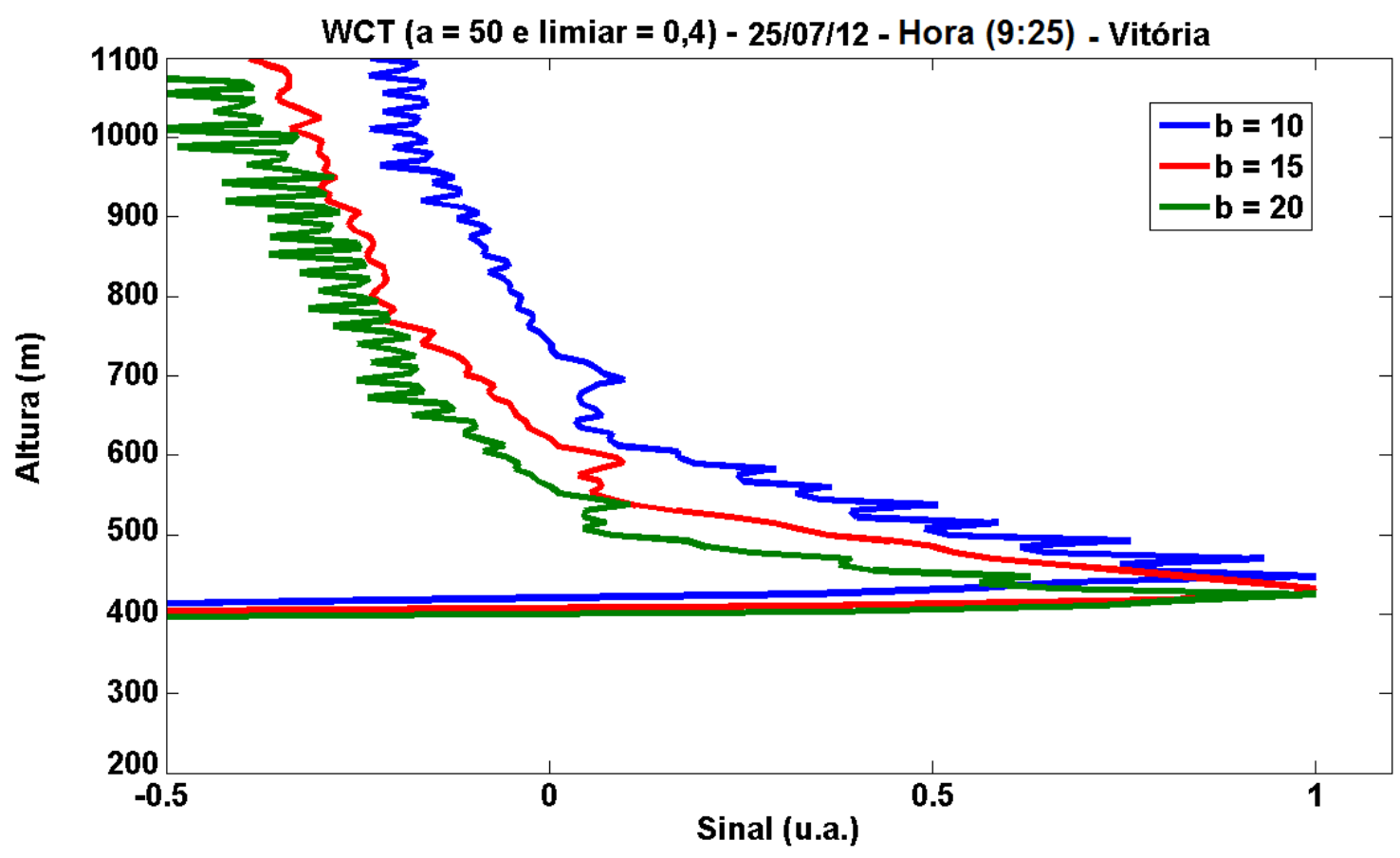

Figura 5.12: Método WCT com variação de "b"

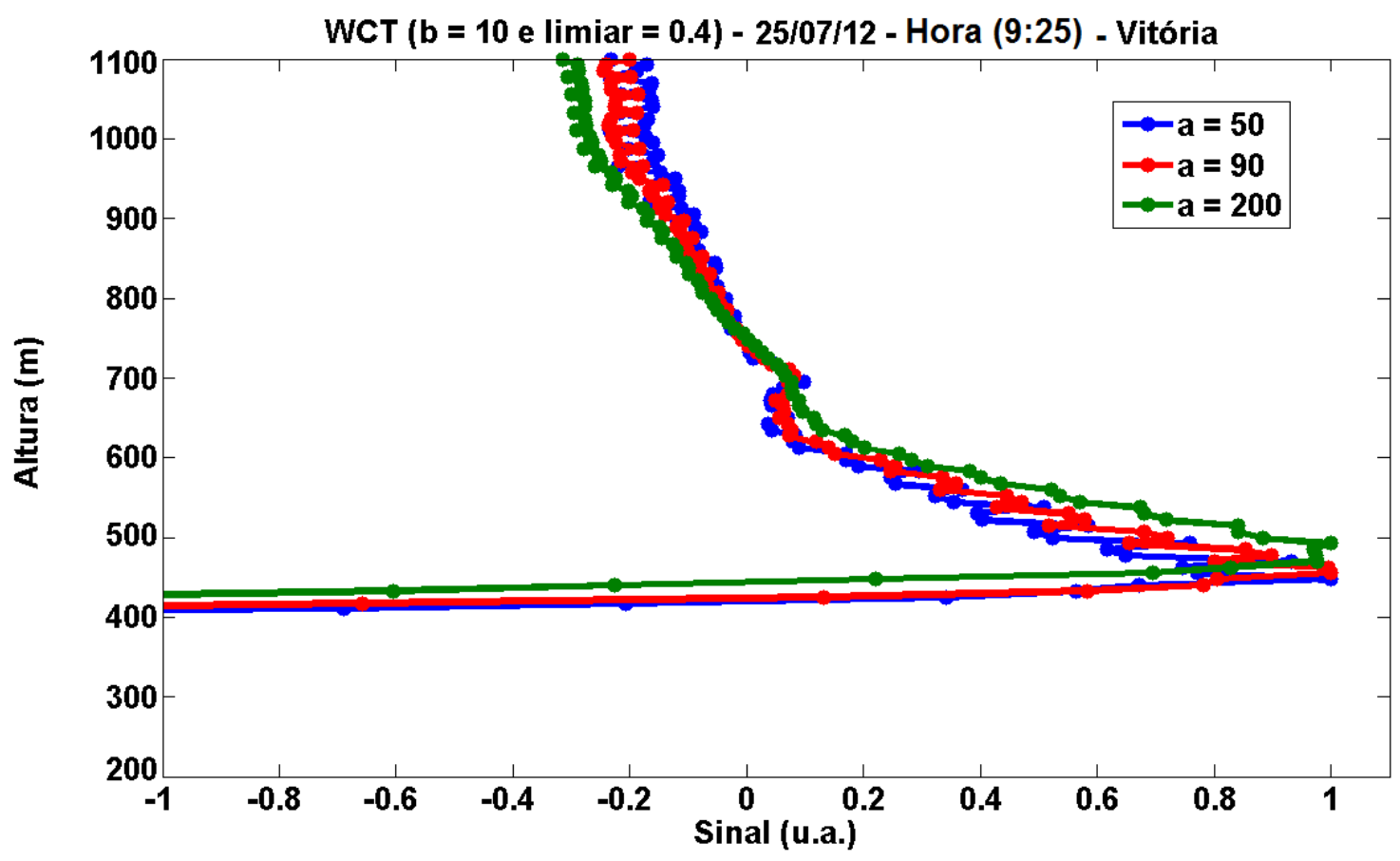

Figura 5.13: Método WCT com variação de "a" 


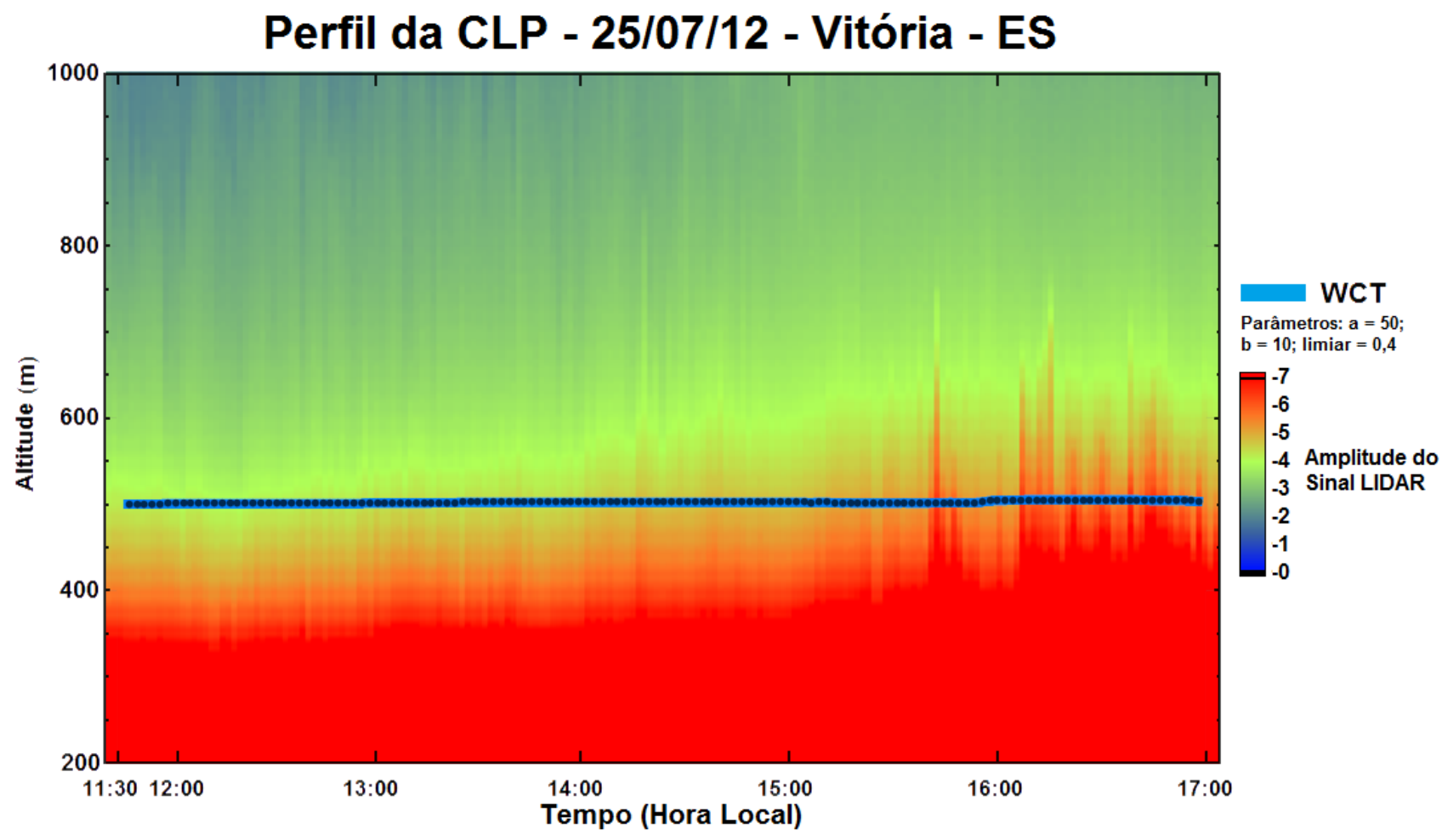

Figura 5.14: Método da WCT

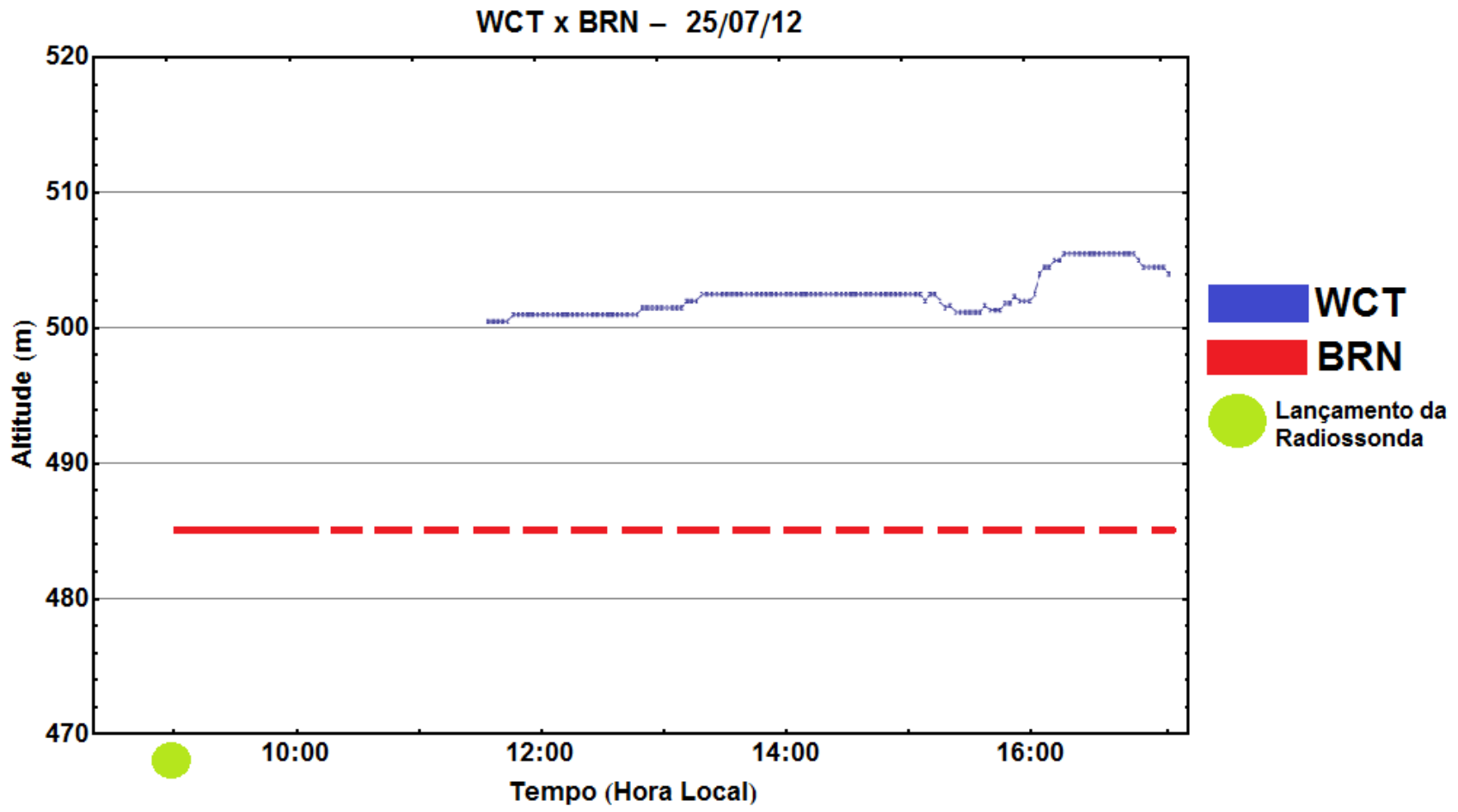

Figura 5.15: Comparação entre o Método WCT e o BRN 


\subsubsection{Avaliação dos Métodos para a situação de 'Calmaria'}

Com exceção da Variância que possui grandes oscilações, todos os métodos apresentam resultados condizentes com o esperado (Fig. 5.16), apresentando em média, curvas bem próximas com diferenças, com relação ao BRN, não superiores a 30 metros. Vale destacar que o tempo de processamento para todos os métodos foi relativamente baixo.

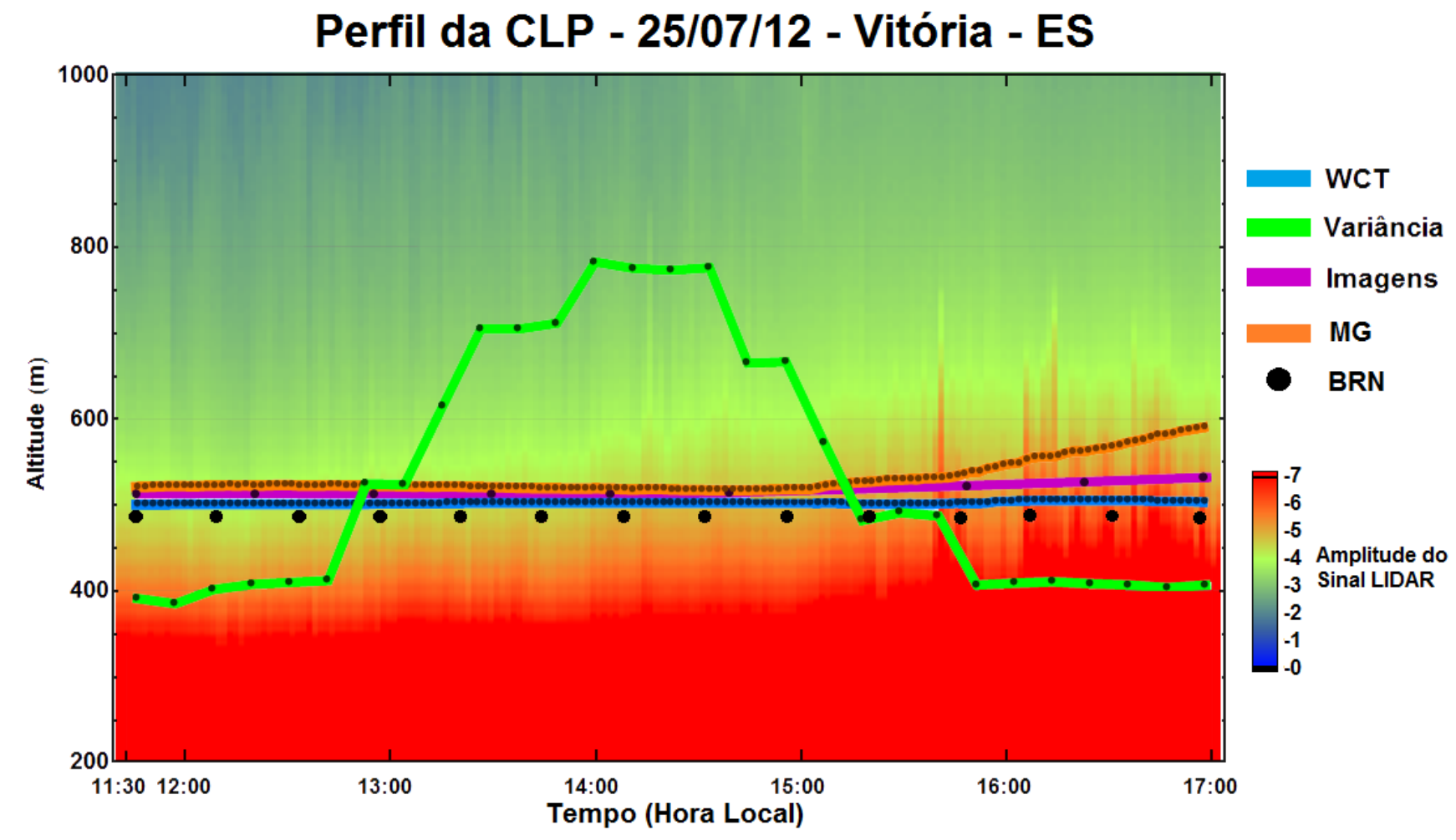

Figura 5.16: Comparação entre os métodos 


\subsubsection{Situação de Presença de subcamadas de aerossóis e/ou camadas de nuvens}

Esta medida foi realizada na cidade de Vitória - ES no dia 26 de julho de 2012 no período das 8:39 horas até às 16:55 horas. A atmosfera apresentou um perfil bem similar ao de calmaria, tendo como principais diferenças: uma intensidade de ventos um pouco superior a situação de "calmaria"e presença de algumas nuvens no período entre 11 e $14: 30$ horas.

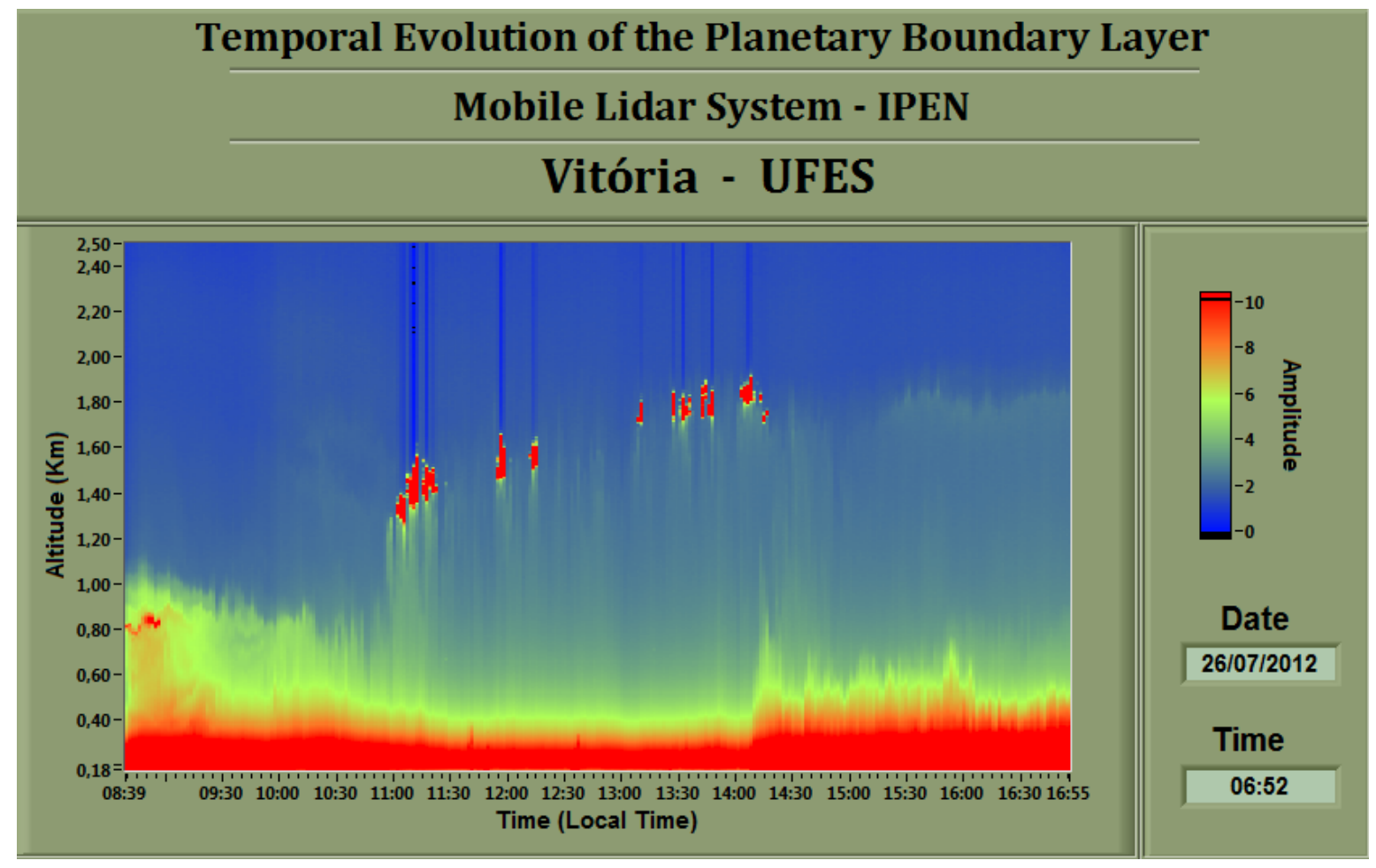

Figura 5.17: Perfil lidar para um dia com pequena concentração de Nuvens 


\subsubsection{Método da Variancia aplicado a situação de Presença de subcamadas de aerossóis e/ou camadas de nuvens}

Para a realização deste método foi tomado um conjunto de 30 perfis Lidar e depois realizada a média móvel para cada conjuno de 15 pontos, o que dá ao gráfico um resolução temporal cerca de 10 vezes inferior a do Lidar.

Devido a existência de maiores variações dentro do perfil Lidar, a Variância passa a apresentar melhores resultados, representando satisfatoriamente o perfil da CLP na maior parte da medida. Porém este método não consegue realizar a separação entre o topo da CLP e as pequenas camadas de nuvens (Fig. 5.18).

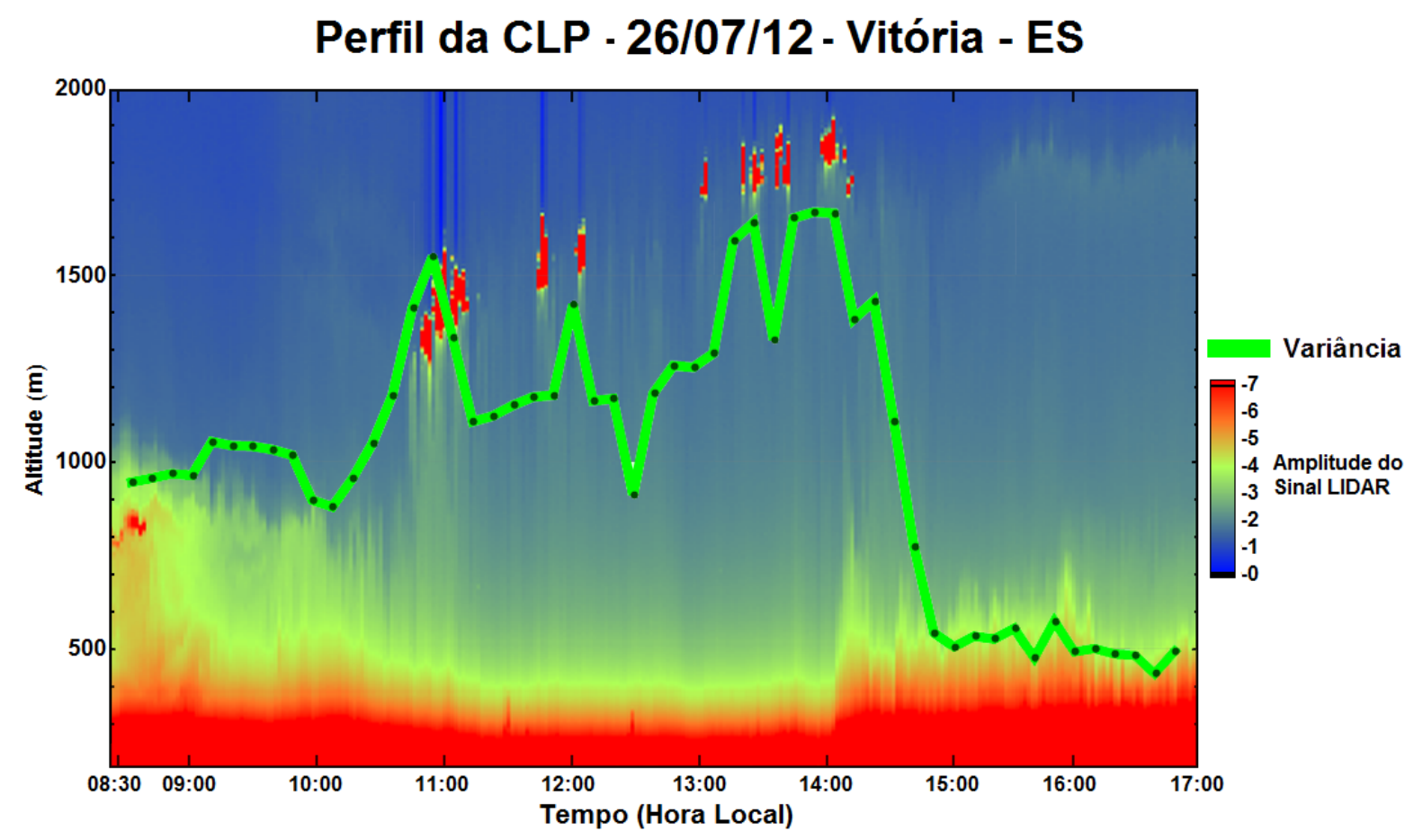

Figura 5.18: Método da Variância

A Fig. 5.19 exibe a comparação entre o BRN e o método da Variância, onde é possível observar maior proximidade entre estes na parte inicial do gráfico, porém há um grande distanciamento entre estes na região onde há nuvens. 


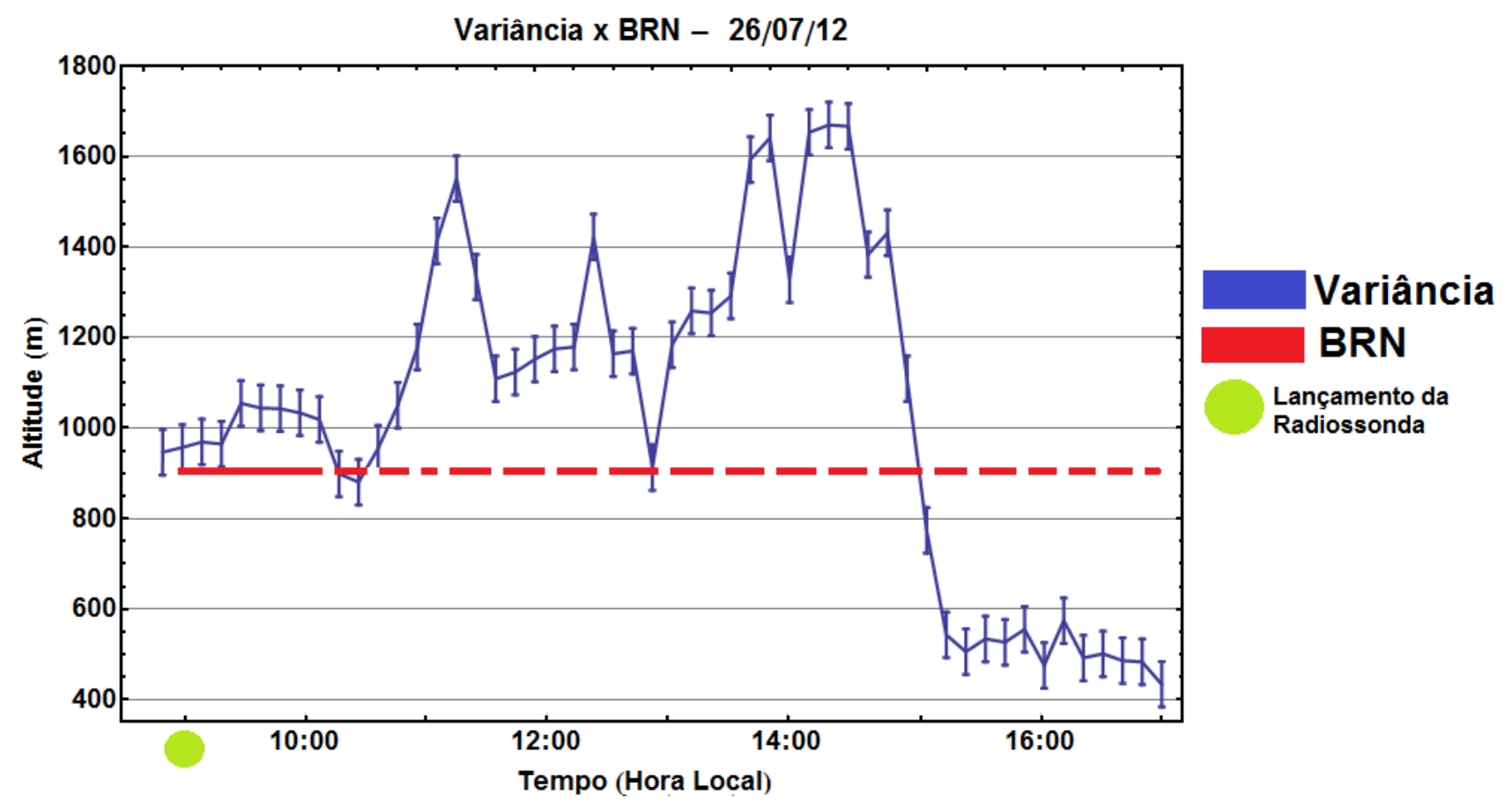

Figura 5.19: Comparação entre o Método da Variância e o BRN 


\subsubsection{Método das Imagens aplicado a situação de Presença de subcamadas de aerossóis e/ou camadas de nuvens}

Neste caso para a geração da curva, foi realizada a média móvel para cada conjunto de 5 pontos, dando a figura final uma resolução temporal cerca de 20 vezes inferior a do Lidar.

Este método apresenta dificuldades no momento de separar o que seria o topo da CLP e a camada de nuvens (Fig. 5.20), gerando um perfil que representa parcialmente as oscilações da CLP, porém na presença das nuvens fica posicionado de forma intermediária entre estas e o valor esperado para a CLP. Em comparação com o BRN (Fig. 5.21) este método também não apresenta resultados satisfatórios nas regiões onde há incidência de nuvens, com um distanciamento de até $300 \mathrm{~m}$. Nos pontos onde não há nuvens os resultados são satisfatórios.

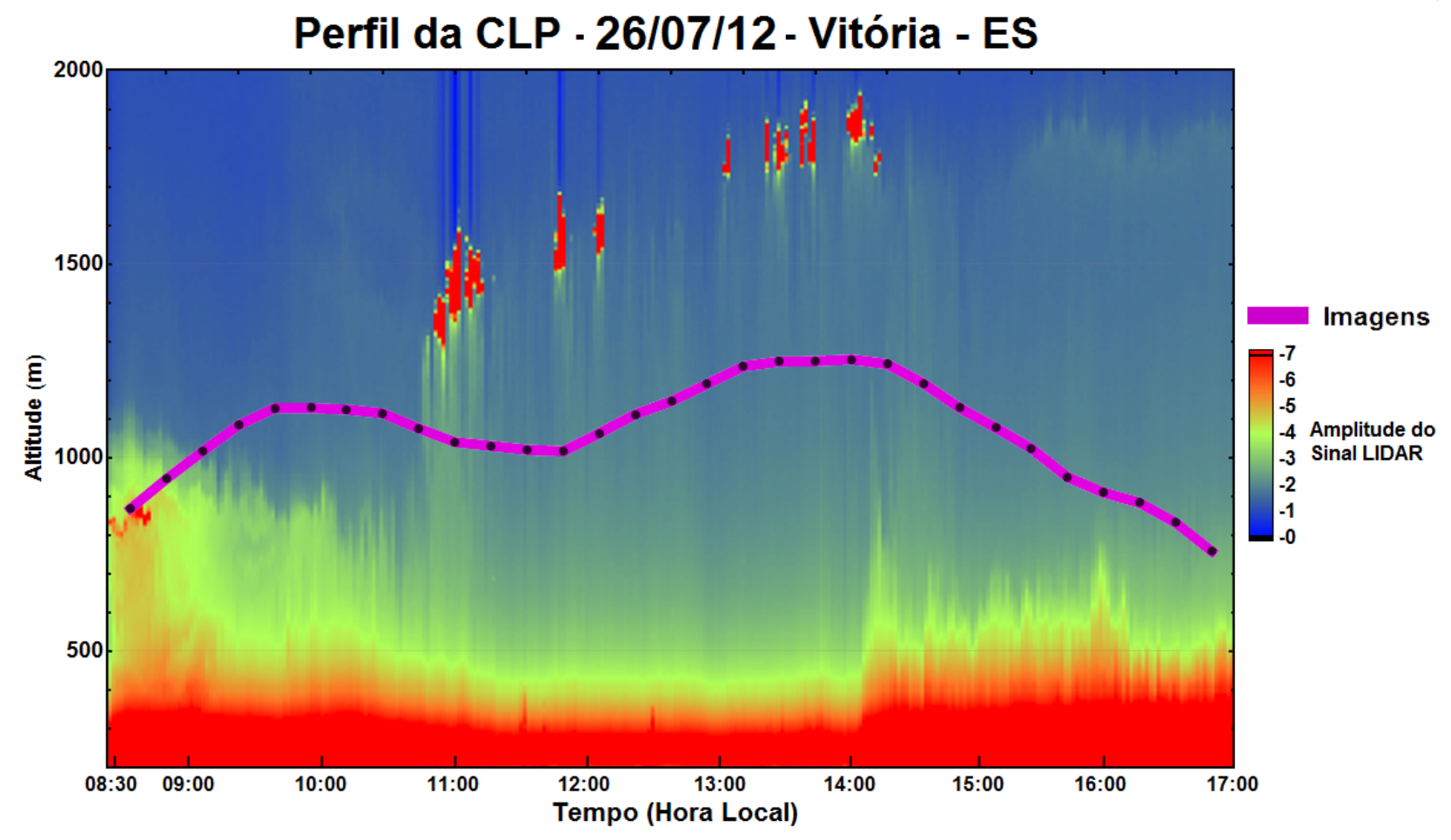

Figura 5.20: Método das Imagens 


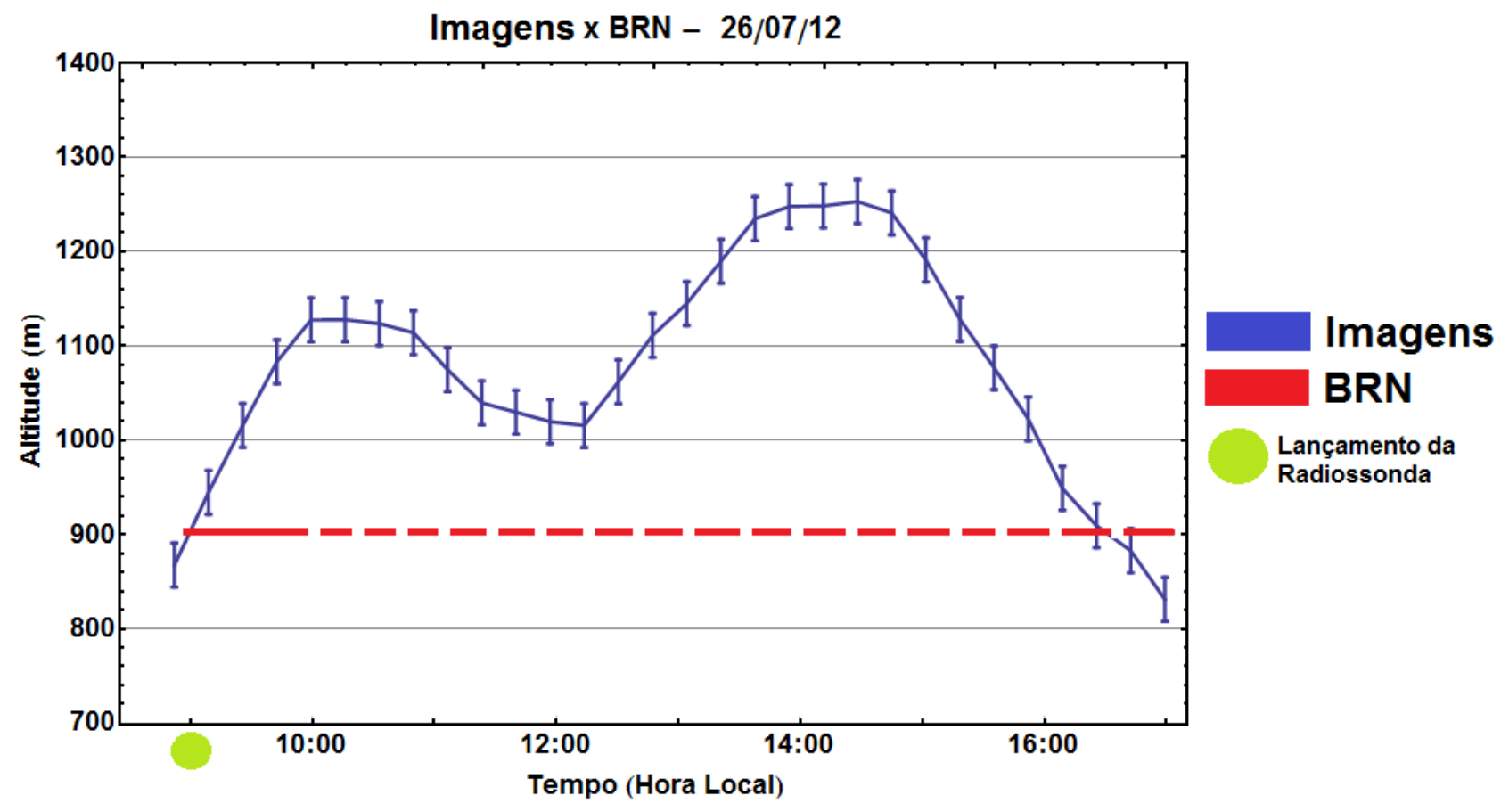

Figura 5.21: Comparação entre o Método das Imagens e o BRN 


\subsubsection{Método do Gradiente aplicado a situação de Presença de subcamadas de aerossóis e/ou camadas de nuvens}

Quando há presença de subcamadas de nuvens e/ou aerossóis, surgem pontos de mínimo local no perfil (Fig. 5.22), portanto a utilização do limiar se torna mais importante, para que seja possível realizar a correta identificação do ponto de mínimo que corresponde ao topo da CLP, fazendo assim a distinção entre esta e as nuvens existentes no perfil.

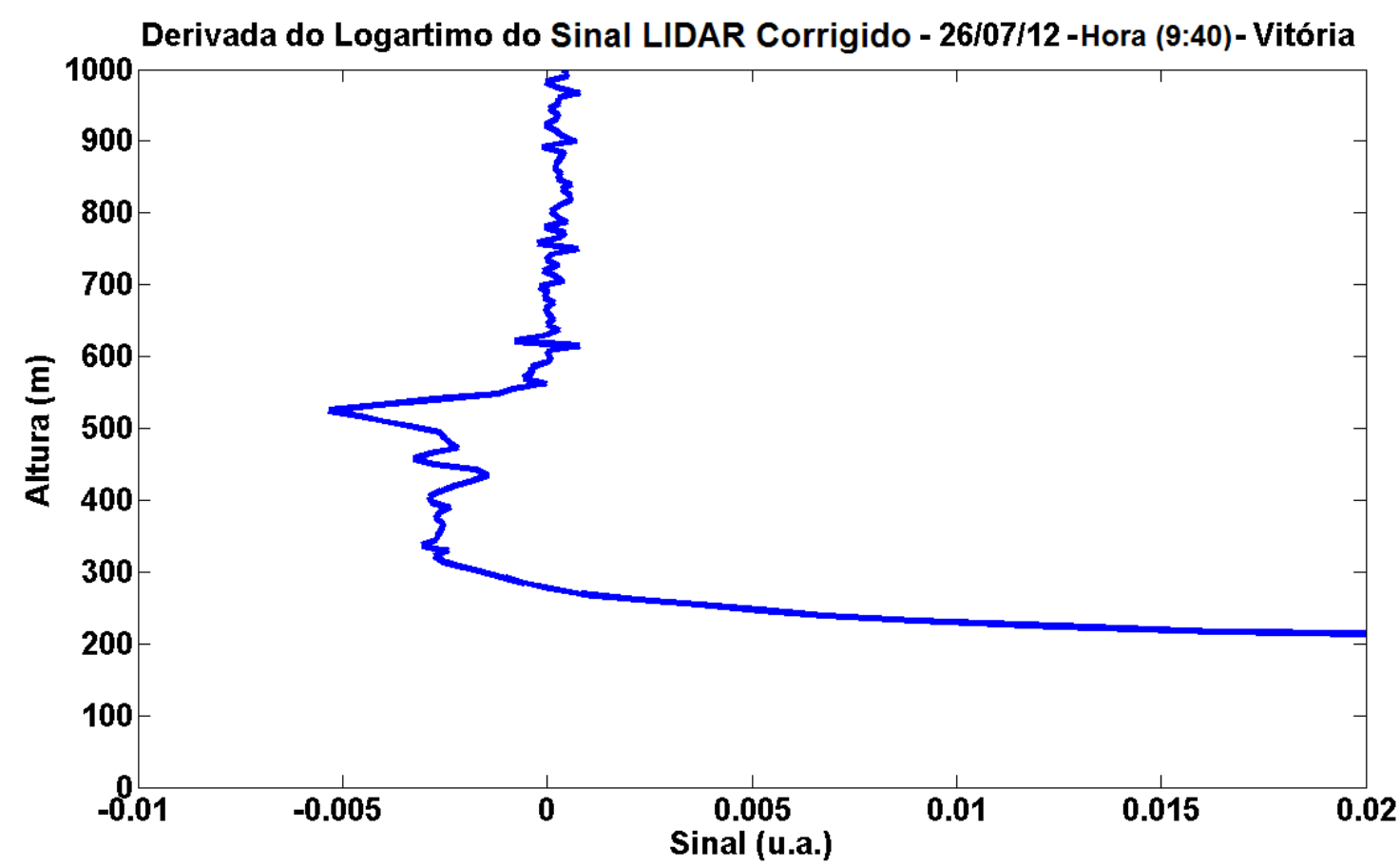

Figura 5.22: Perfil Individual obtido a partir do Método do Gradiente

No entanto a escolha do limiar deve ser feita com certa cautela, pois para valores muito baixos o método se confunde facilmente gerando perfis com valores muito distantes do esperado. E para valores altos acaba gerando perda de informações com relação ao desenvolvimento do perfil (Fig. 5.23).

O melhor resultado foi obtido com limiar $=-0,04$, porém para nenhuma das iterações realizadas, o método fez uma correta distinção entre as subcamadas de nuvens e o topo da CLP (Fig. 5.24). Em comparação com o BRN (Fig. 5.25), apenas em alguns pontos os resultados foram compatíveis.

A resolução temporal da curva gerada pelo método é cerca quatro vezes inferior a 
do Lidar, uma vez que foi realizada a média móvel para conjuntos de 60 pontos.

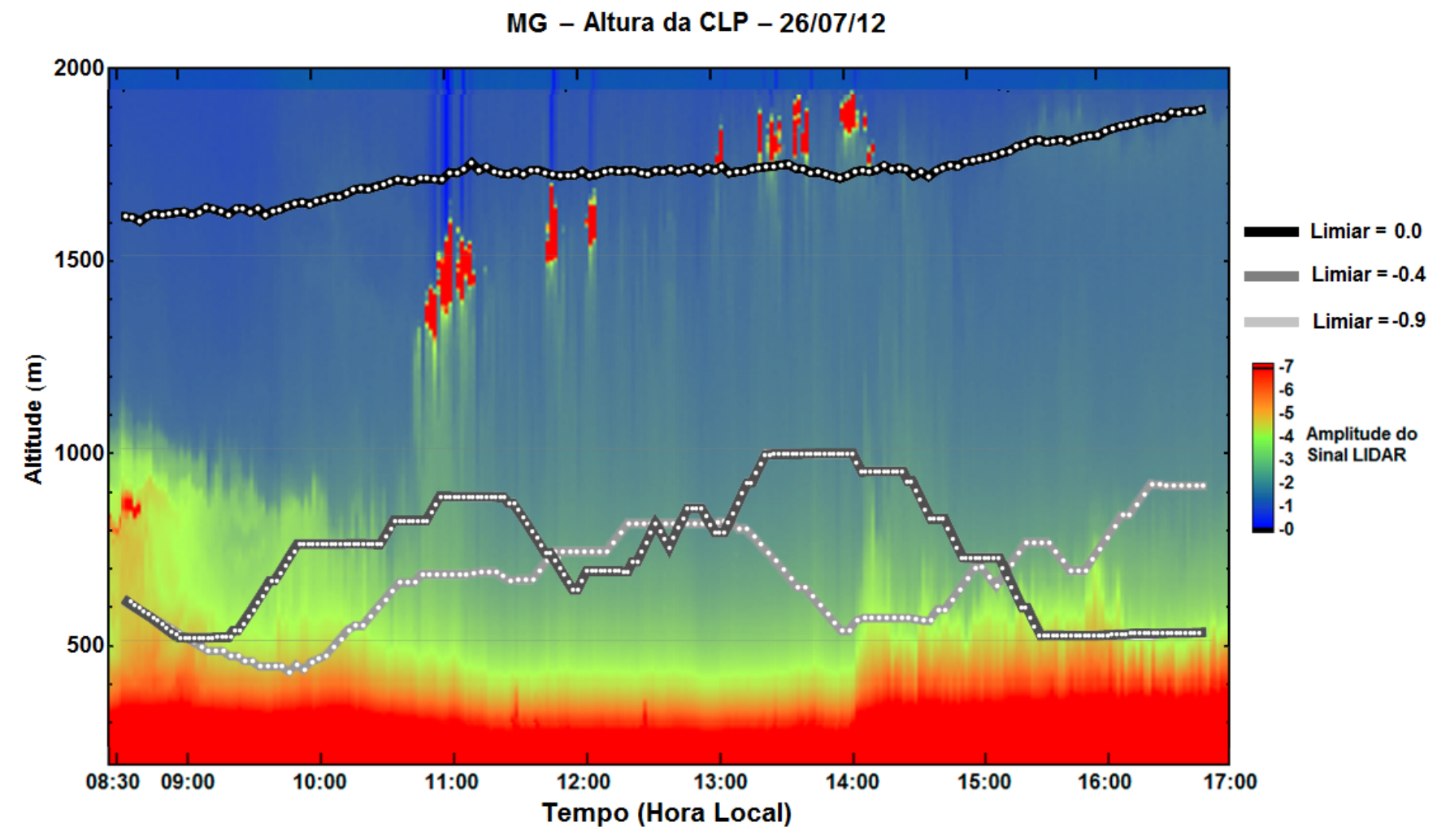

Figura 5.23: Método do Gradiente com variação de Limiar 


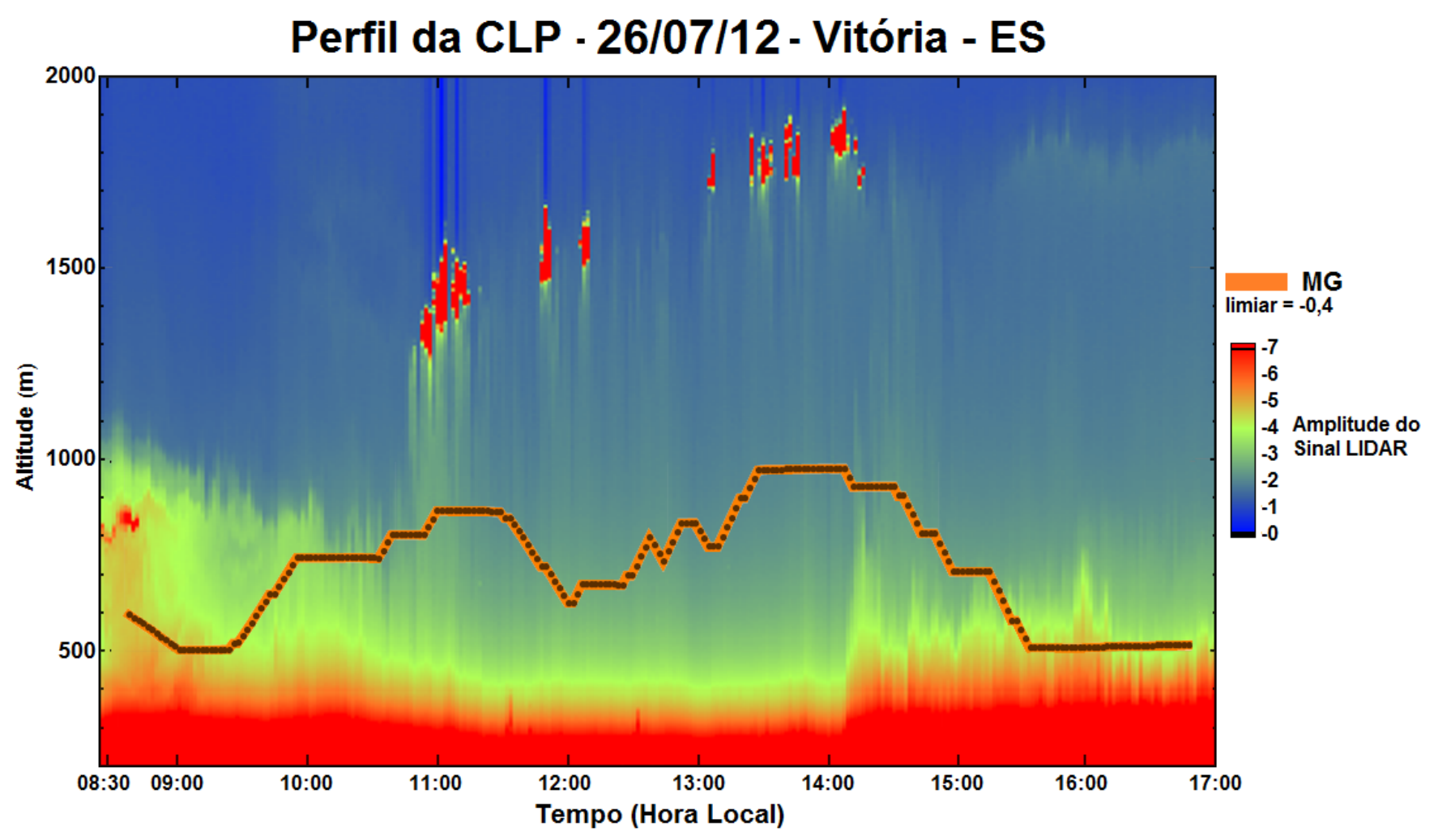

Figura 5.24: Método do Gradiente

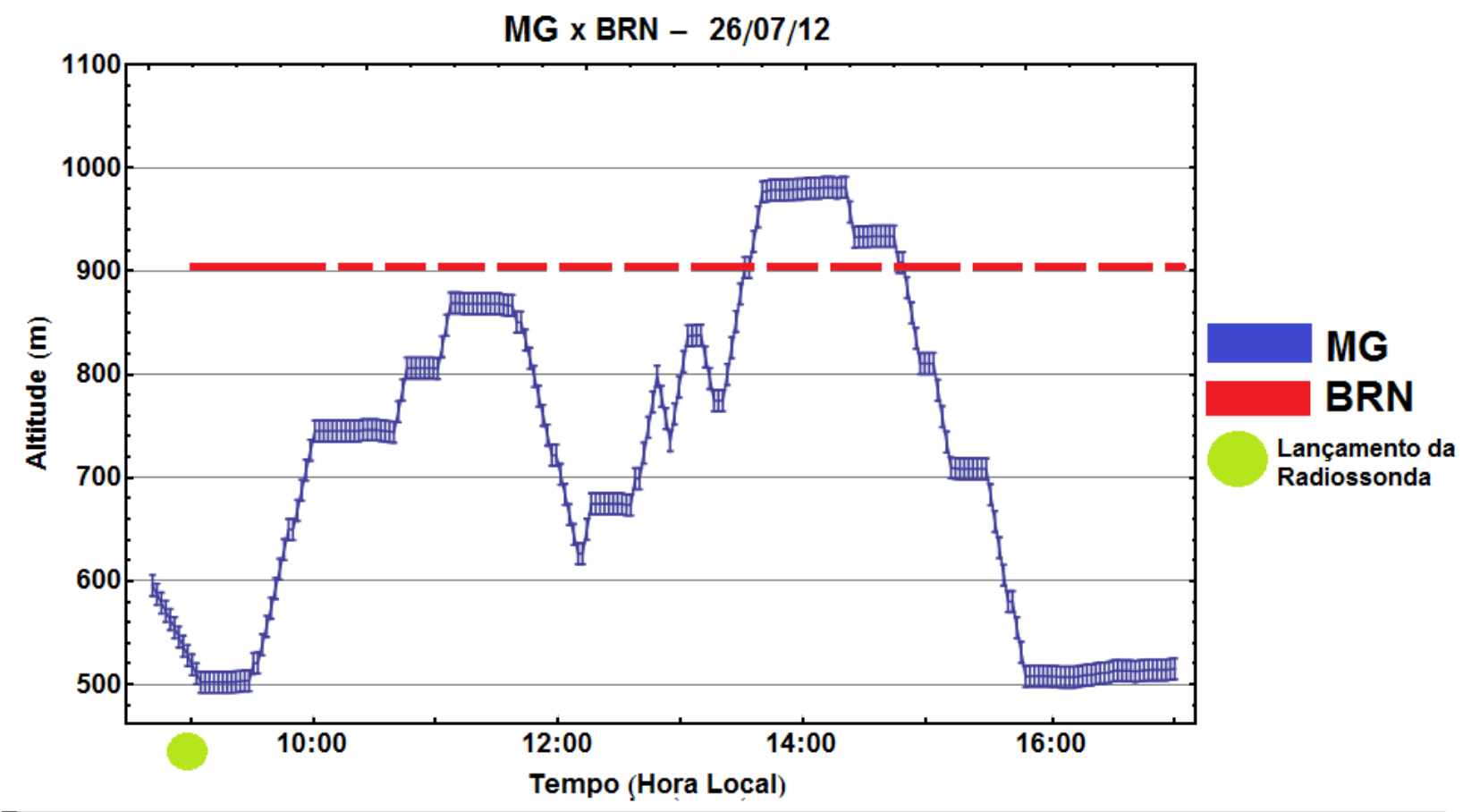

Figura 5.25: Comparação entre o Método do Gradiente e o BRN 


\subsubsection{Método Wavelet Covariance Transform aplicado a situação de Presença de subcamadas de aerossóis e/ou camadas de nuvens}

Neste método, a presença das nuvens gera o aparecimento de máximos locais (Fig. 5.26), com isto a utilização do limiar torna-se ainda mais importante, gerando diferenças que são fundamentais para garantir a correta detecção do ponto de máximo que corresponde ao topo da CLP (Fig. 5.29).

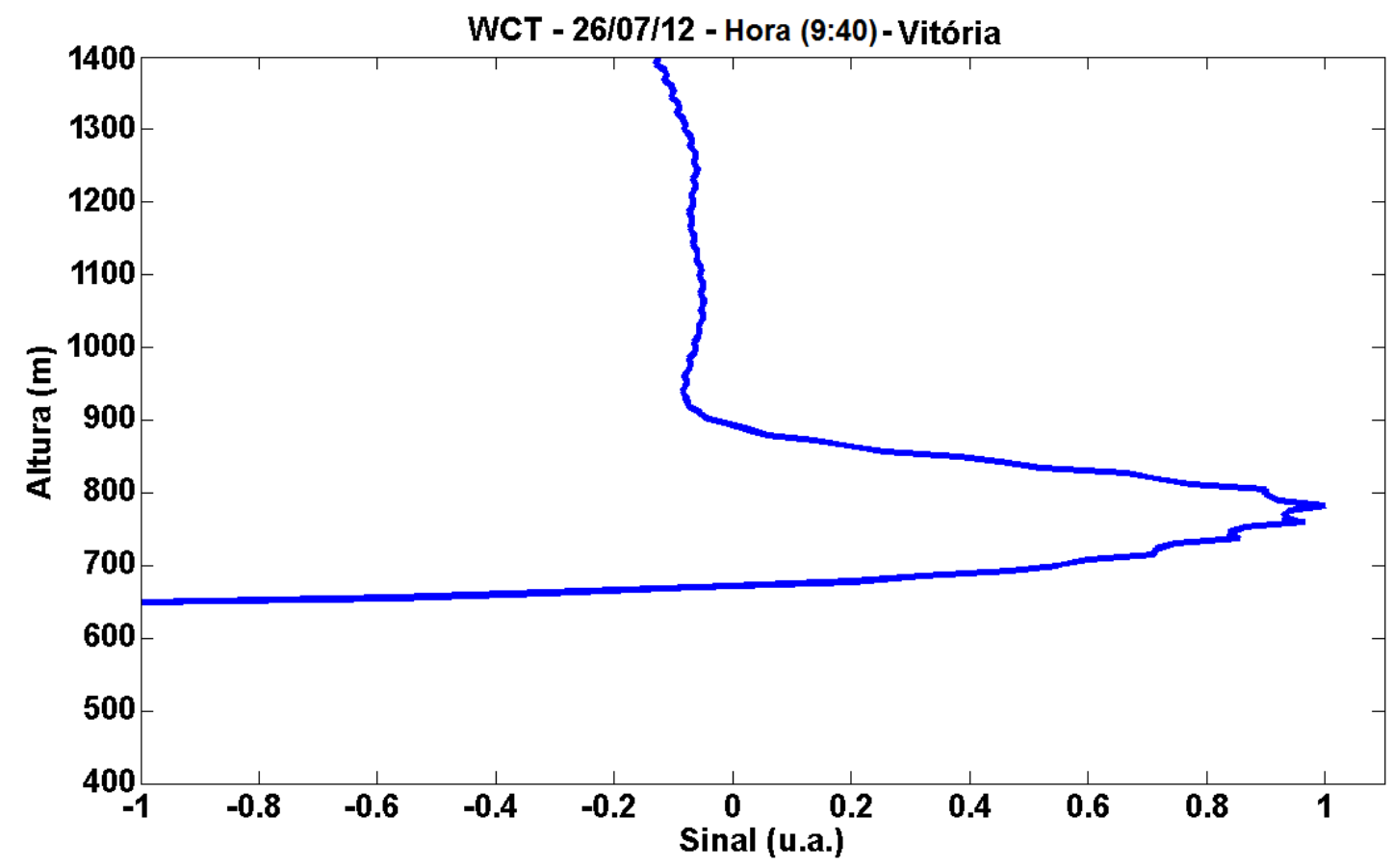

Figura 5.26: Perfil Individual obtido a partir do Método WCT

Agora a escolha dos parâmetros $a$ e $b$ também passa a ser mais complexa, sendo necessária a escolha de um valor alto para a (o que garante uma maior suavização da curva - Fig. 5.27) e um baixo valor para $b$ (Fig. 5.28), para garantir um maior detalhamento da função.

A Fig. 5.30 mostra o perfil gerado pelo método WCT, onde os seguintes parâmetos foram utilizados: $a=200, b=10$ e limiar $=0.8$. Embora minimizada, a influência das nuvens não foi totalmente eliminada. A Fig. 5.31 exibe a comparação entre o método e o BRN, onde pode-se observar que embora existam grandes oscilações nas distâncias entre os dois (chegando a $300 \mathrm{~m}$ em determinados pontos) há diversos momentos de 


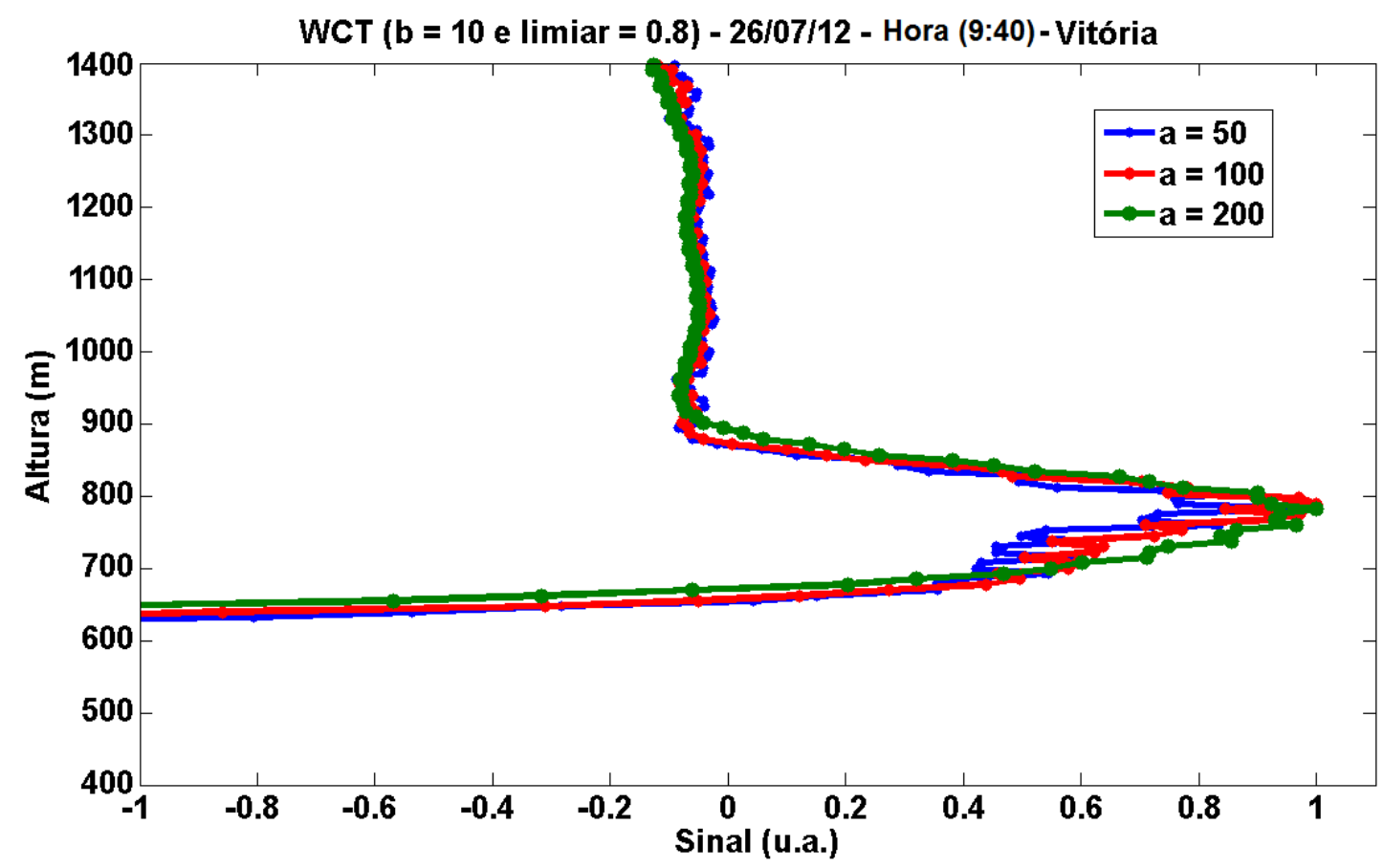

Figura 5.27: Método WCT com variação de "a"

proximidade.

Quanto a resolução temporal, foi realizada a média móvel. para cada conjunto de 60 pontos, o que dá a figura final uma resolução temporal 4 vezes inferior a do Lidar. 


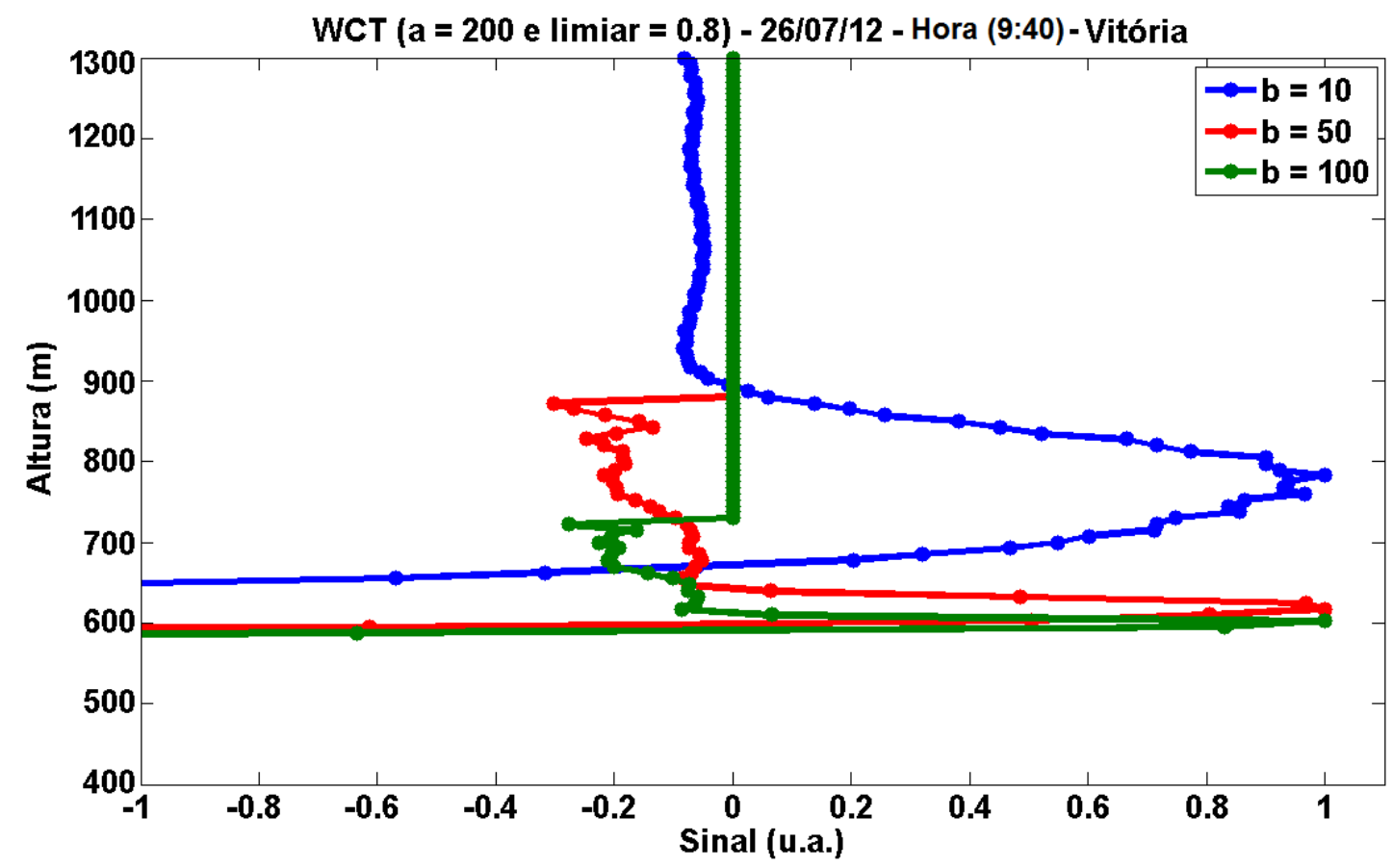

Figura 5.28: Método WCT com variação de "b"

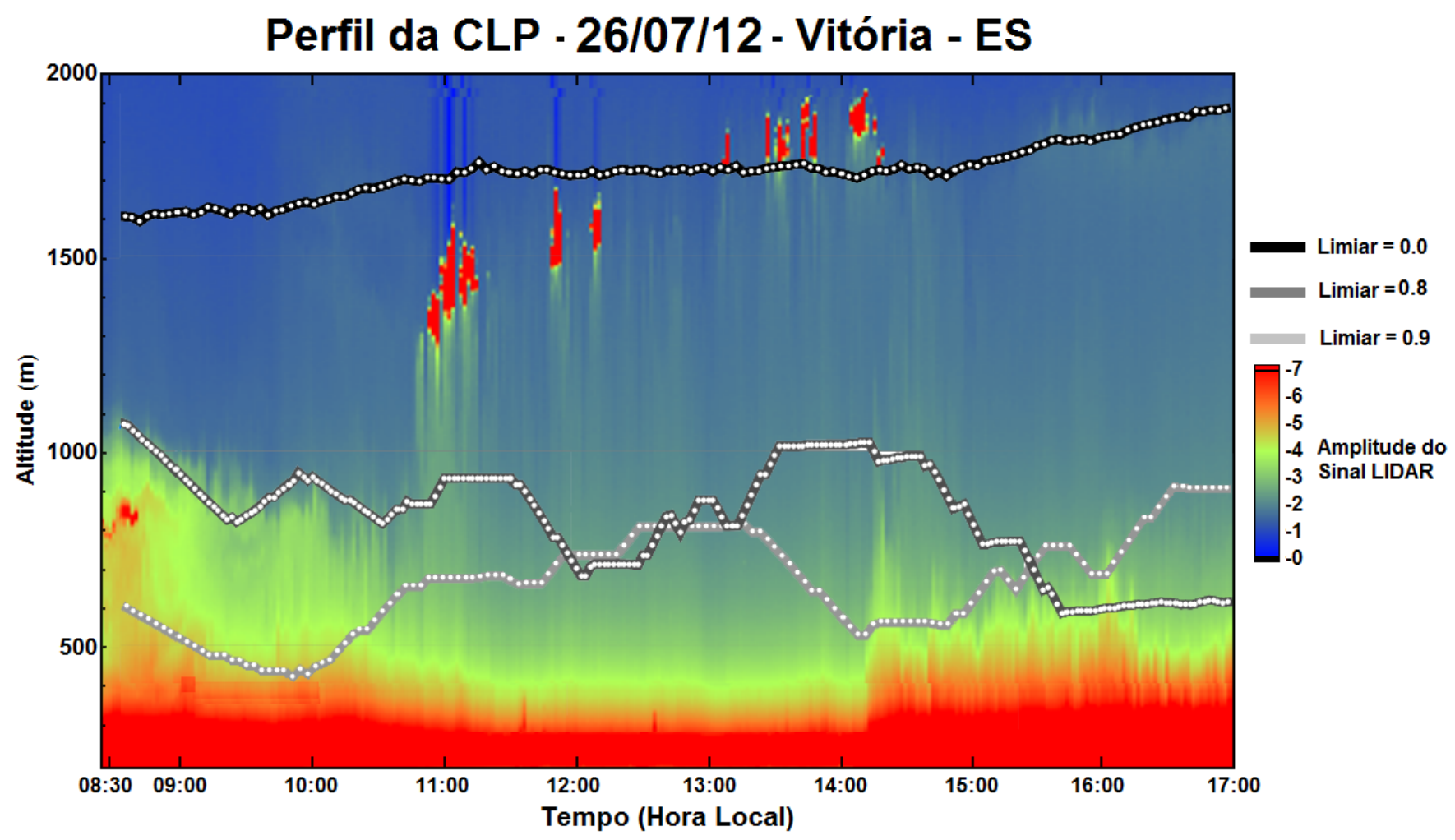

Figura 5.29: Método WCT com variação de limiar 


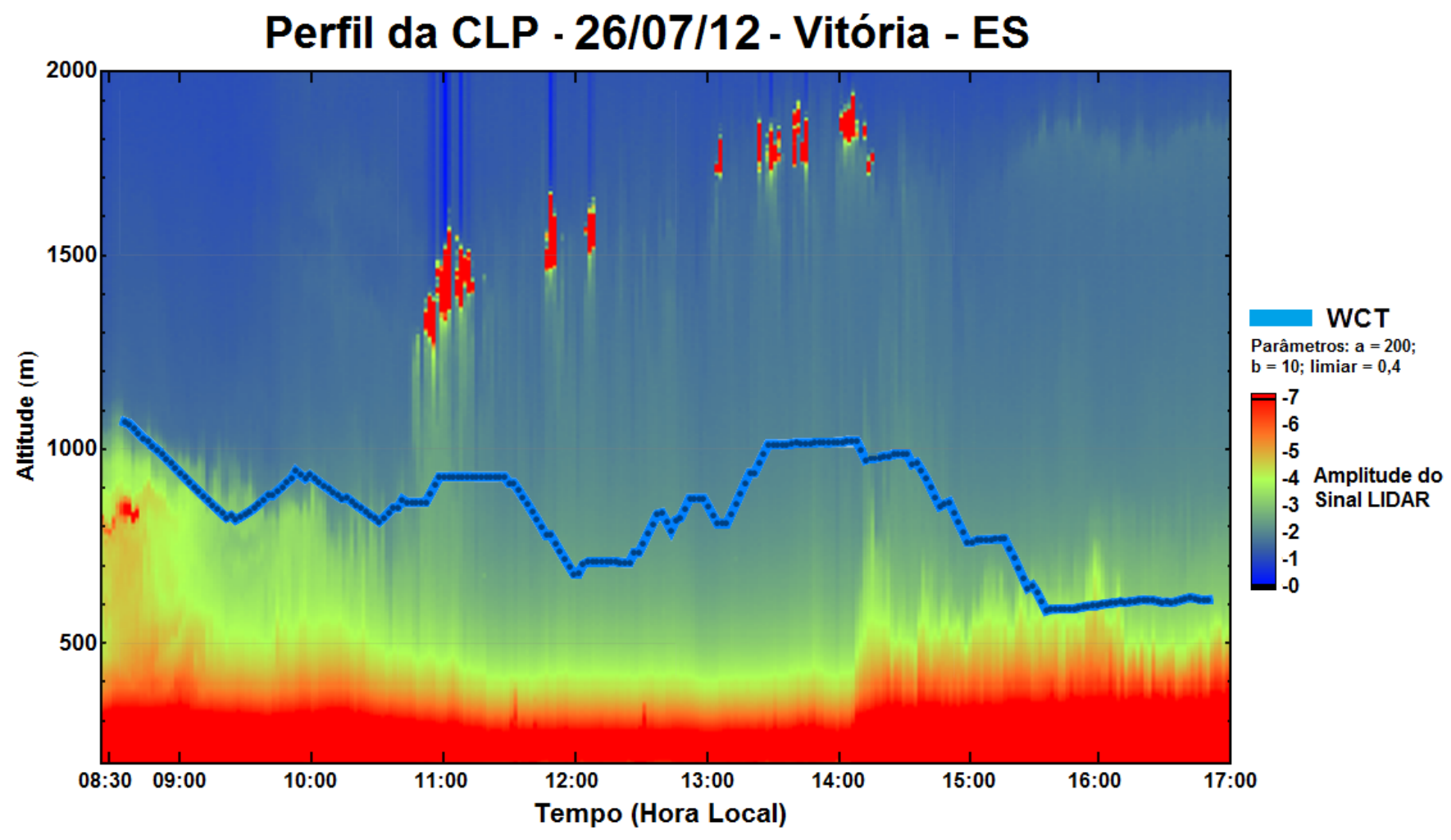

Figura 5.30: Método da WCT

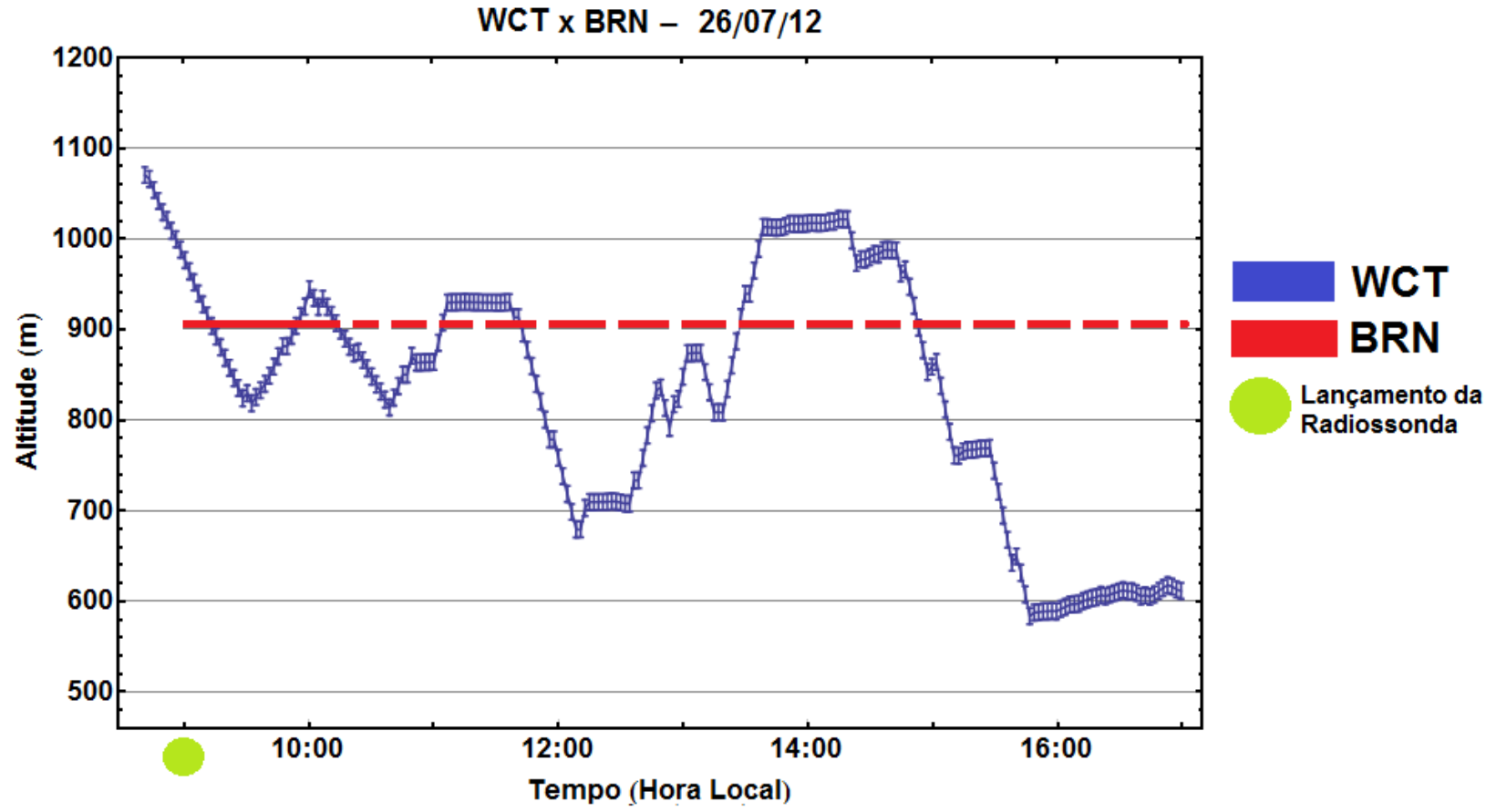

Figura 5.31: Comparação entre o Método WCT e o BRN 


\subsubsection{Avaliação dos Métodos para a situação de Presença de subcamadas de aerossóis e/ou camadas de nuvens}

A presença de nuvens fez com que a maioria dos métodos se confundisse no momento de detecção do topo da CLP, como por exemplo o método das Imagens, o qual apresenta resultado com qualidade inferior, quando comparado ao obtido na situação de calmaria.

O MG também apresentou resultados um pouco inferiores aos obtidos anteriormente, além de também possuir um aumento no seu tempo de processamento aumentado, dada a necessidade de um maior refinamento na escolha do valor correto para o limiar. O WCT também teve o seu tempo de processamento aumentado, dada a necessidade de escolha dos parâmetros a e b, no entanto dentre os métodos, este é o que mais se aproxima do valor esperado.

O método da Variância apresenta evolução em relação ao resultado da situação anterior, uma vez que a presença de nuvens e algumas subcamadas de aerossóis geram mais oscilações no perfil da CLP, favorecendo o método, porém o mesmo não consegue separar o topo da CLP das nuvens existentes entre 10:30 e 14:20 horas (Fig. 5.32). 


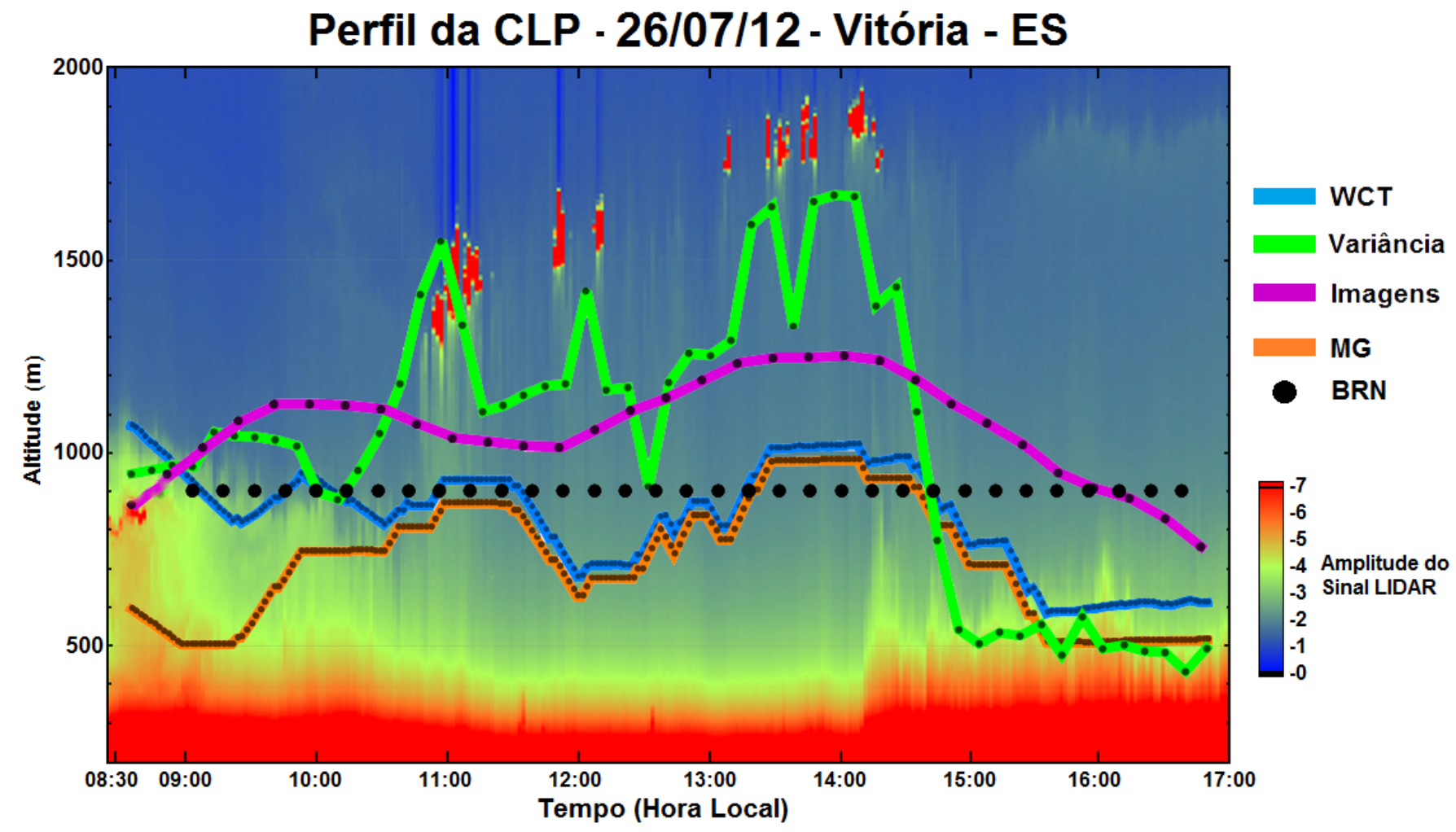

Figura 5.32: Comparação entre os métodos 


\subsubsection{Situação de 'Turbulência'}

A tomada de dados foi realizada na cidade de Vitória - ES no dia 28 de julho de 2012 no período das 14:25 às 17:52 horas. Este dia antecede a chegada de uma frente fria, sendo caracterizado por uma intensidade de ventos bastante superior a apresentada pelas situações anteriores e grande presença de subcamadas de aerossóis dentro da CLP, principalmente por volta das 16:20 (Fig. 5.33).

Para este dia é importante destacar que o resultado obtido para o BRN não condiz com o gerado pela análise visual do perfil, apresentado um valor de 238,9 metros para a altura da CLP no período da manhã. Isto se deve a baixa resolução da radiossondagem do dia.

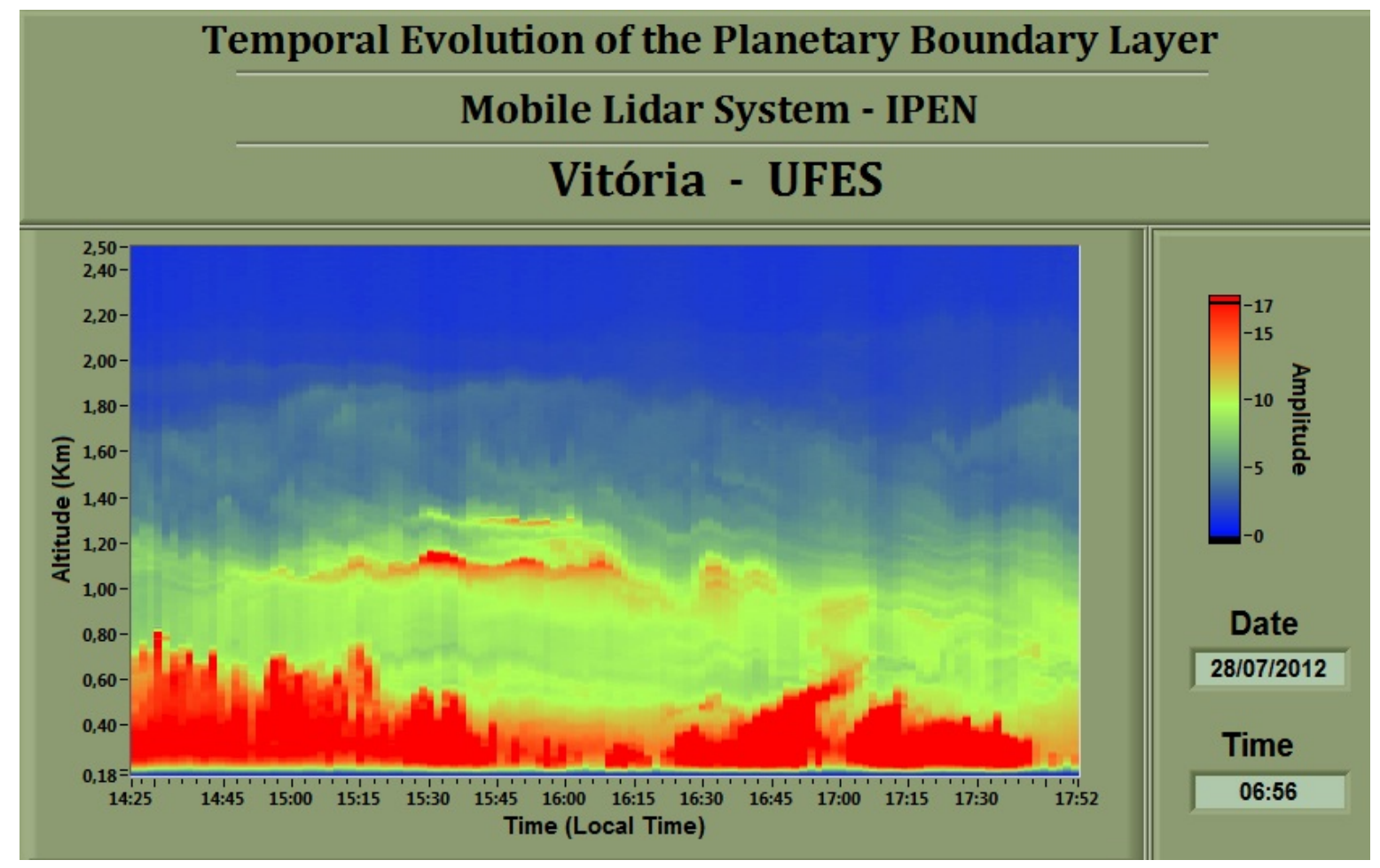

Figura 5.33: Perfil lidar para um dia de Turbulência 


\subsubsection{Método da Variância aplicado a situação de 'Turbulência'}

Nesta análise, foi utilizado um conjunto de 30 perfis para a realização da variância e, em seguida realizada a média móvel de um conjunto de 15 pontos, dando ao gráfico final uma resolução temporal cerca de 10 vezes inferior a do Lidar.

Este método apresenta um resultado dentro do esperado a partir da análise visual, possuindo apenas algumas dificuldades no final do perfil devido a alta concentração de aerossóis na parte baixa da atmosfera (Fig. 5.34). Assim como mencionado na literatura [15], o método da Variância possui uma melhor desenvoltura para dias em que a atmosfera possui perfis complexos.

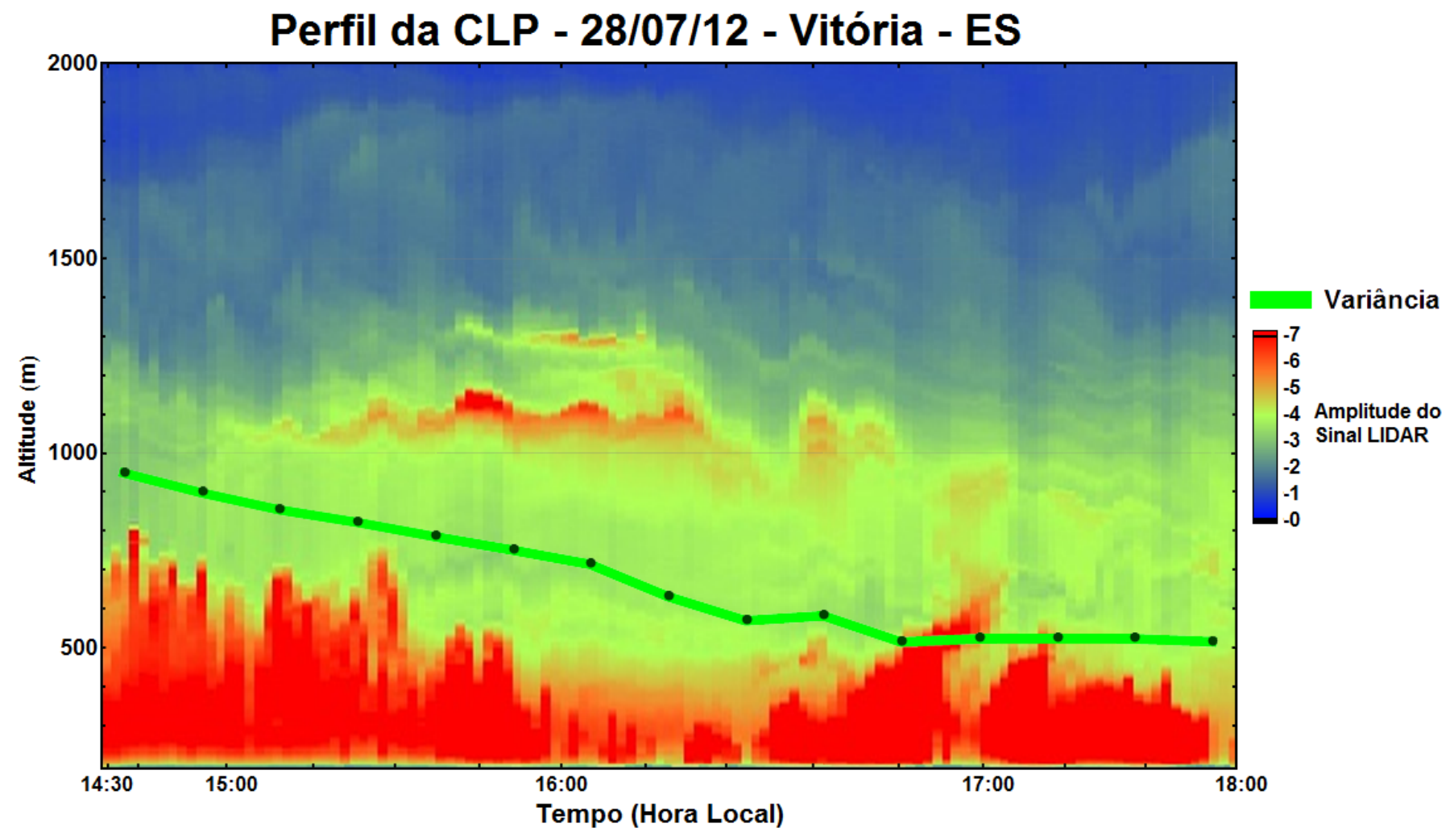

Figura 5.34: Método da Variância

A Fig. 5.35 exibe a comparação entre o Método da Variância e o BRN. 


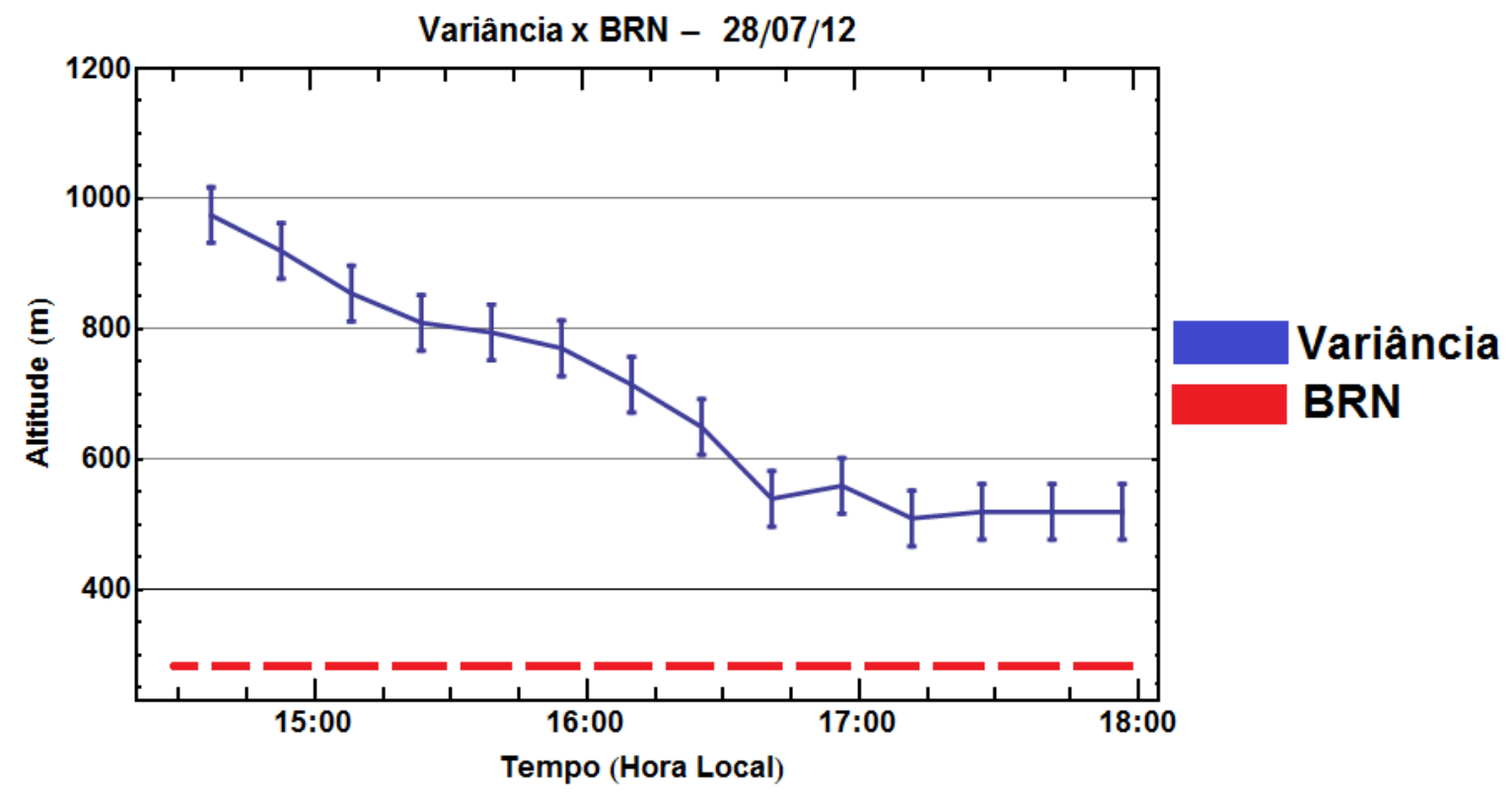

Figura 5.35: Comparação entre o Método da Variância e o BRN 


\subsubsection{Método das Imagens aplicado a situação de 'Turbulência'}

Neste caso para a geração da curva, foi realizada a média móvel para cada conjunto de 5 pontos, dando a figura final uma resolução temporal cerca de 20 vezes inferior a do Lidar.

O método das Imagens apresenta resultados que condizem parcialmente com o esperado, pois embora apresente incialmente bons resultados, surge uma elevação próximo das 16 horas, a qual é gerada pela presença de uma espessa camada de aerossóis. Após a passagem da mesma a curva gerada pelo método começa a declinar e retoma o perfil esperado (Fig. 5.36). Na Fig. 5.37 é feita uma comparação entre o Método das Imagens e o BRN.

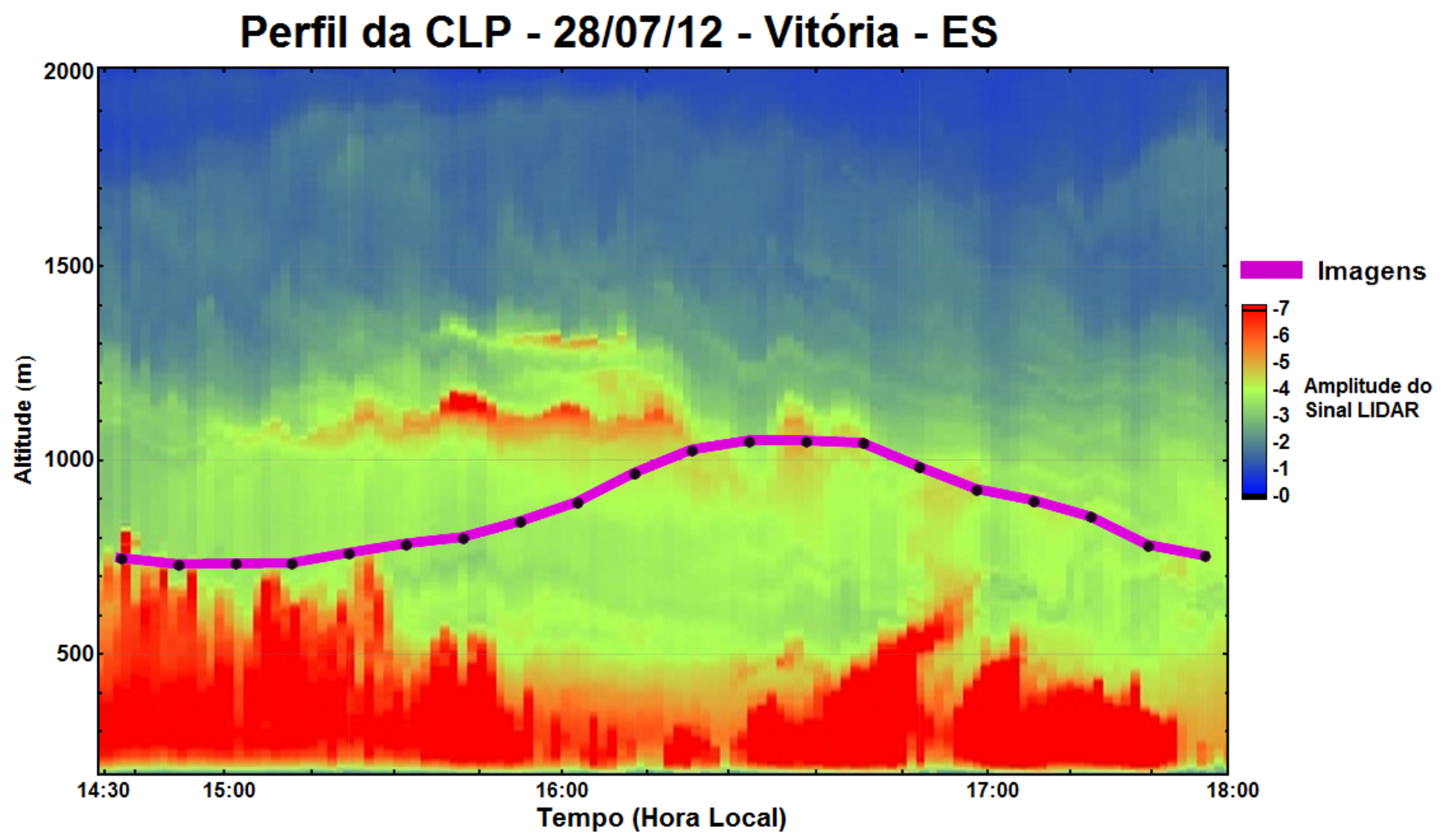

Figura 5.36: Método das Imagens 


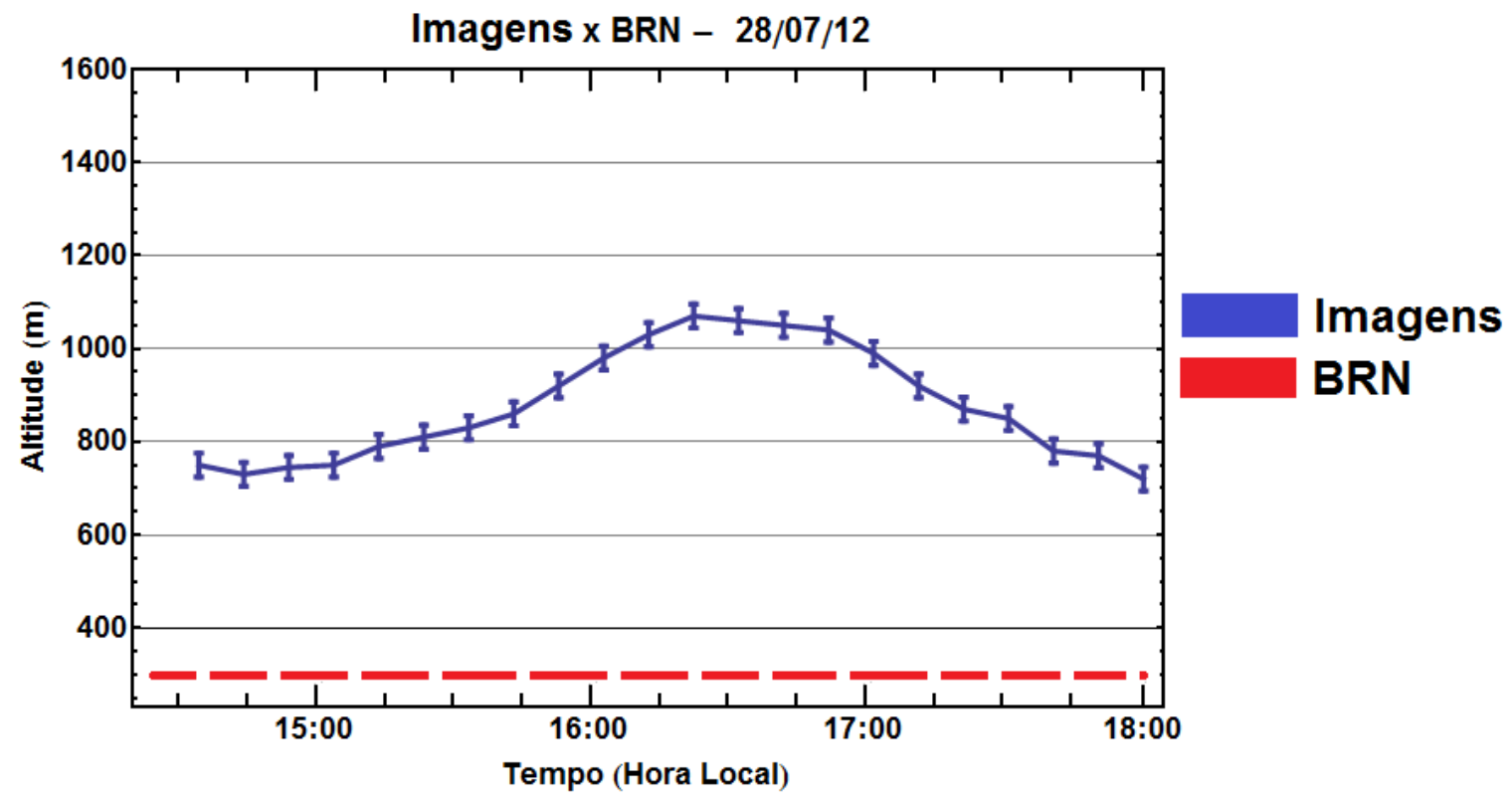

Figura 5.37: Comparação entre o Método das Imagens e o BRN 


\subsubsection{Método do Gradiente aplicado a situação de 'Turbulência'}

Como as subcamadas de aerossóis estão mais concentradas a detecção do mínimo torna-se muito mais complexa, devido a presença de dois ou mais mínimos locais com valores muito próximos (Fig. 5.38).

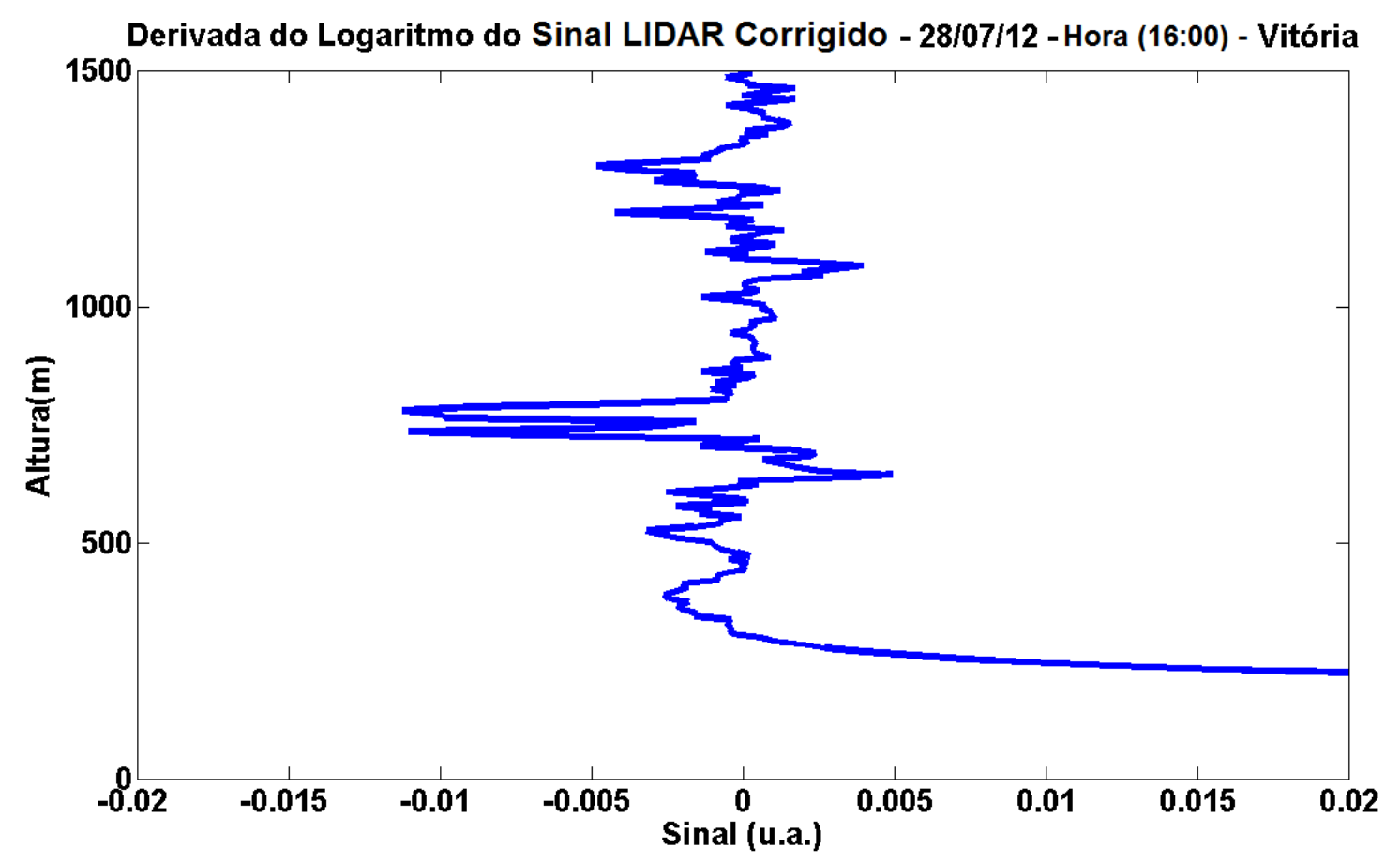

Figura 5.38: Perfil Individual obtido a partir do Método do Gradiente

Portanto a utilização do limiar é imprescindível para uma correta detecção do topo da CLP. Para este caso o melhor resultado foi obtido com limiar = -0,9 (Fig. 5.39), uma vez que os limiares superiores não propiciaram a separação entre o topo da CLP e as camadas de nuvens e aerossóis. A resolução temporal da curva exibida na Fig. 5.39 é quatro vezes inferior a do Lidar, uma vez que foi realizada a média móvel para conjuntos de 60 pontos. A Fig. 5.40 mostra o perfil obtido a partir do método do gradiente mediante a utilização de um limiar igual a -0.9.

Na Fig. 5.41 é feita a comparação entre o Método do Gradiente e o BRN. 


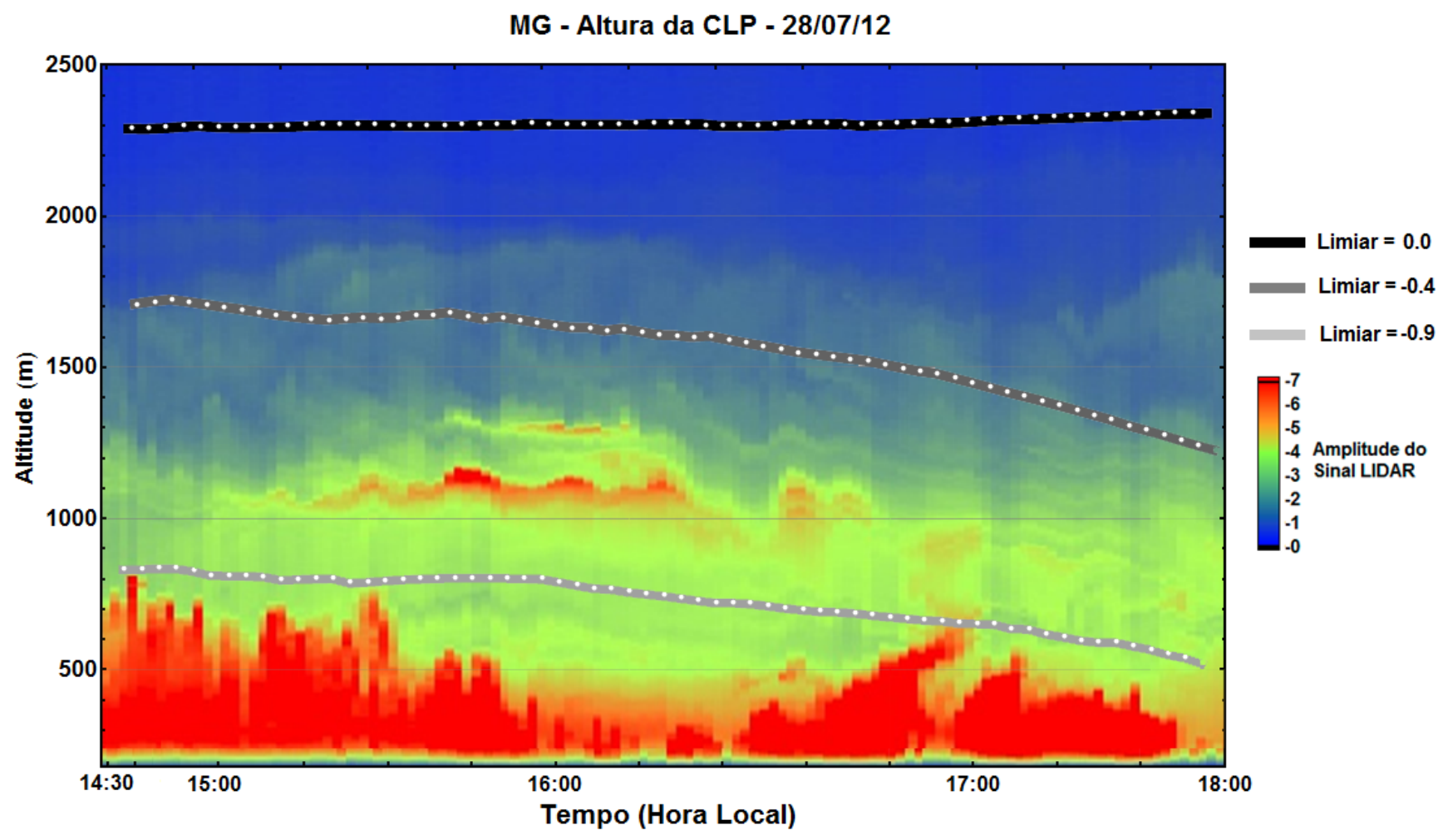

Figura 5.39: Método do Gradiente com variação de Limiar

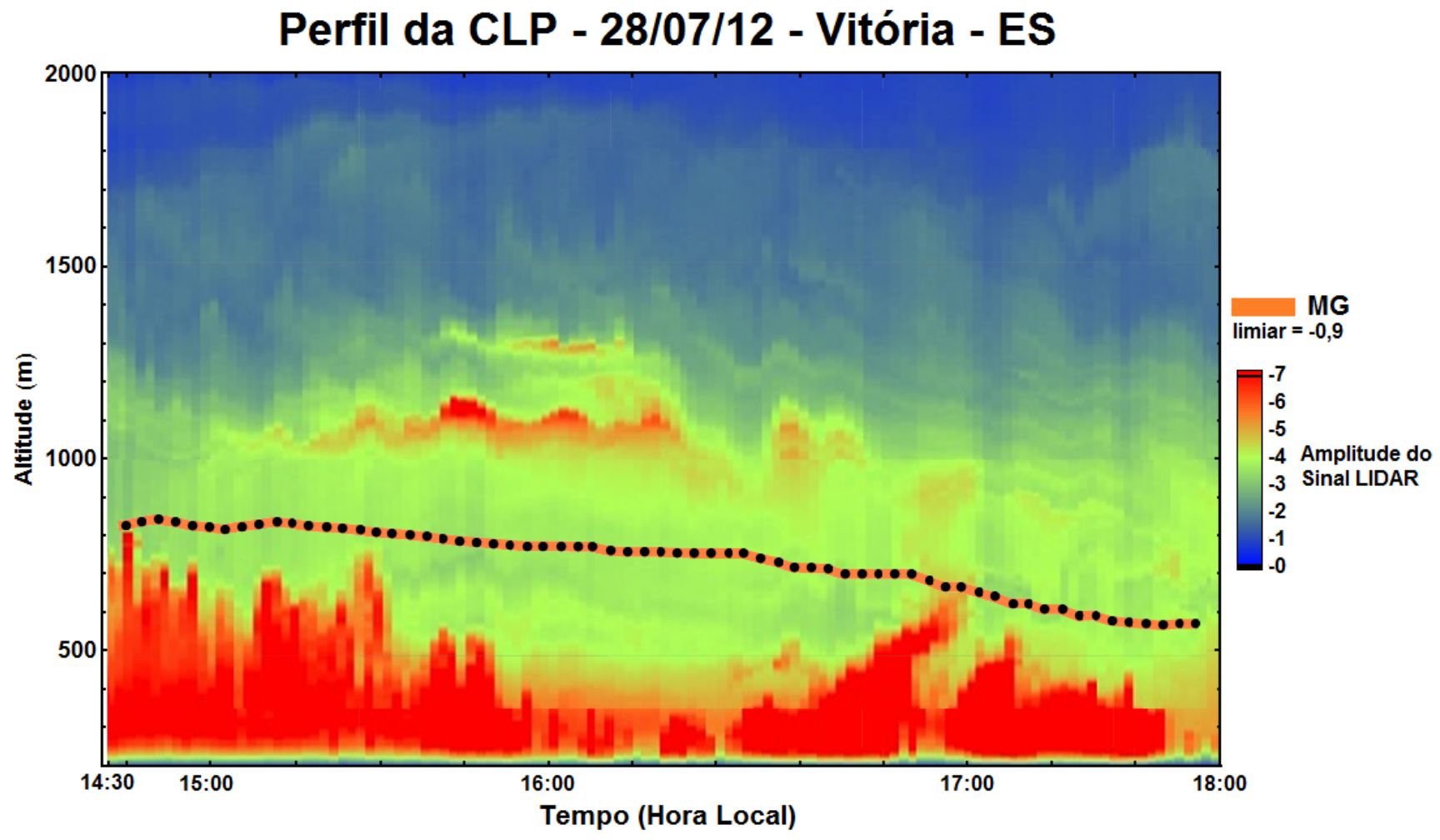

Figura 5.40: Método do Gradiente 


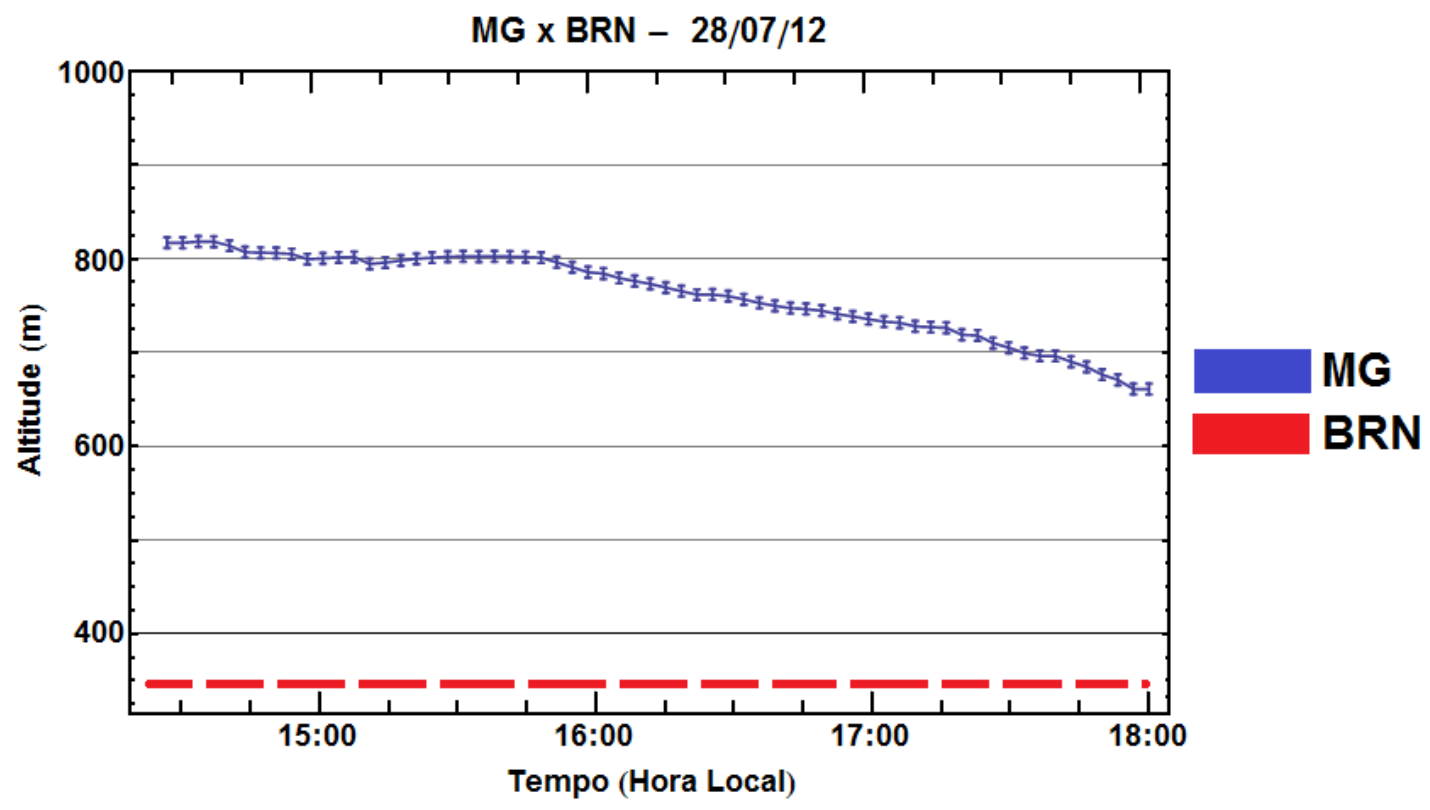

Figura 5.41: Comparação entre o Método do Gradiente e o BRN 


\subsubsection{Método Wavelet Covariance Transform aplicado a situação de 'Turbulência'}

A intensa presença de subcamadas de aerossóis e nuvens gera dois ou mais valores de máximo local muito próximos (Fig. 5.42), logo a detecção do topo da CLP torna-se um pouco mais complexa, sendo necessária uma criteriosa escolha para os valores de $a$ e $b$. Os melhores resultados foram obtidos para grandes valores de a (200) (Fig. 5.43), pois assim foi possível suavizar a função, escapando das oscilações geradas pelas subcamadas; e um valor intermediário para b (40) (Fig. 5.44), o qual possibilita a obtenção de uma função não tão detalhada, porém aproxima o perfil do esperado.

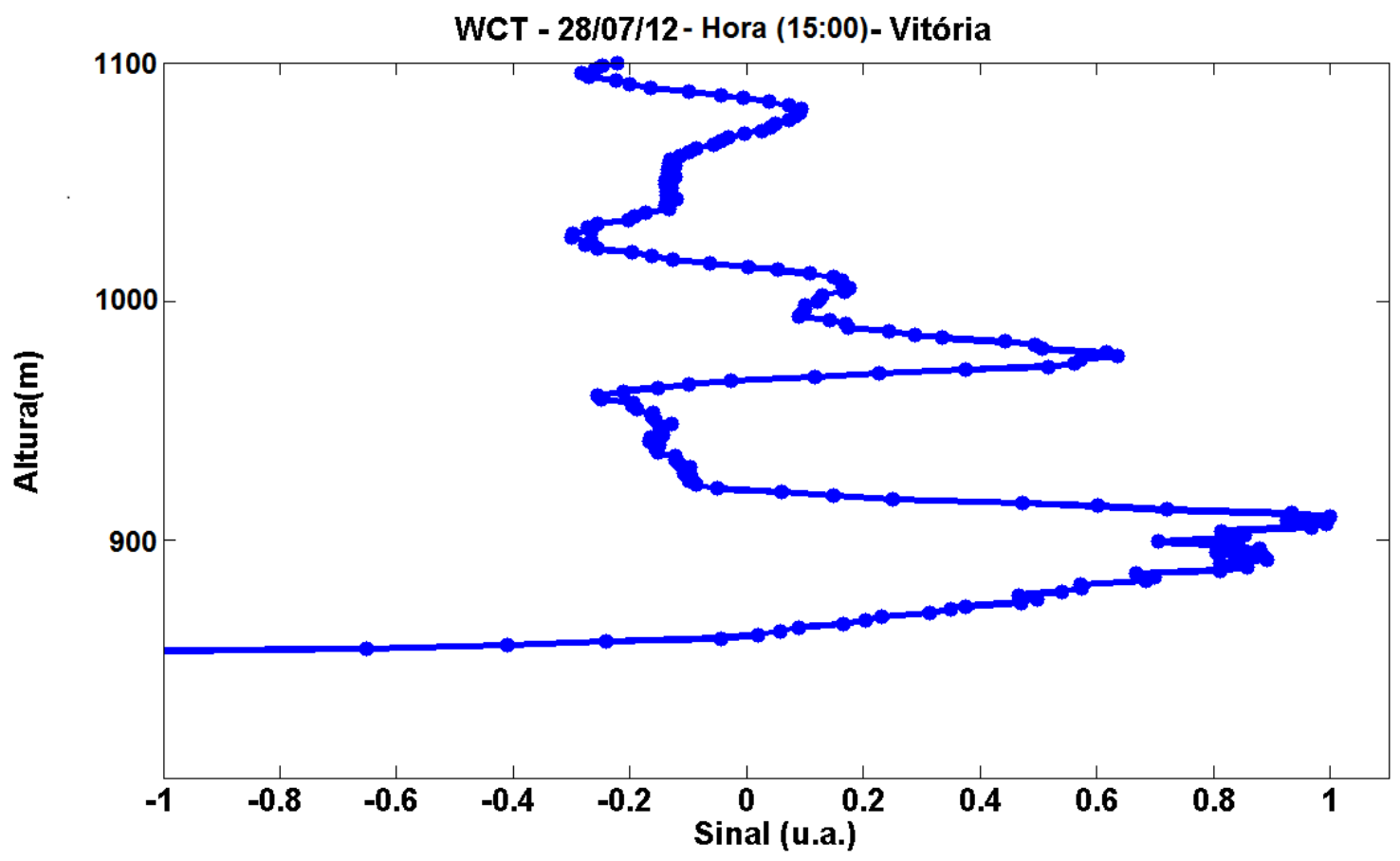

Figura 5.42: Perfil Individual obtido a partir do Método WCT

A utilização correta de um valor de limiar, para filtrar o efeito das nuvens, também se fez muito importante (Fig. 5.45). Para este caso os melhores resultados foram obtidos com limiar $=0,9$. Pois para valores inferiores, o método se confude devido a presença de subcamadas, e não consegue identifcar o topo real da CLP. Foi realizada a média móvel para cada conjunto de 60 pontos, o que dá a curva gerada (Fig. 5.46) uma resolução temporal 4 vezes inferior a do Lidar. 


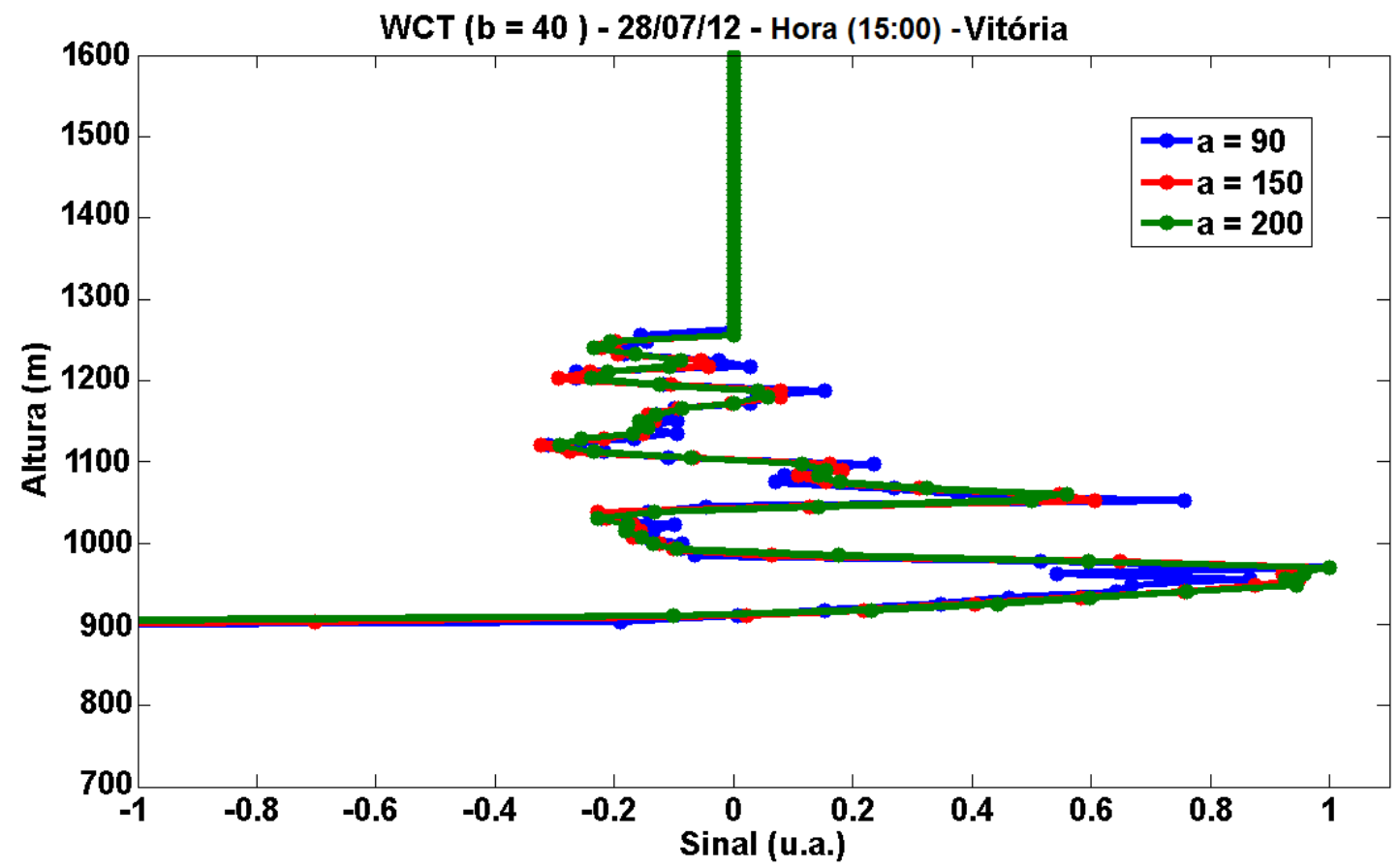

Figura 5.43: Método WCT com variação de "a"

A Fig. 5.47 exibe a comparação entre o método WCT e o BRN. 


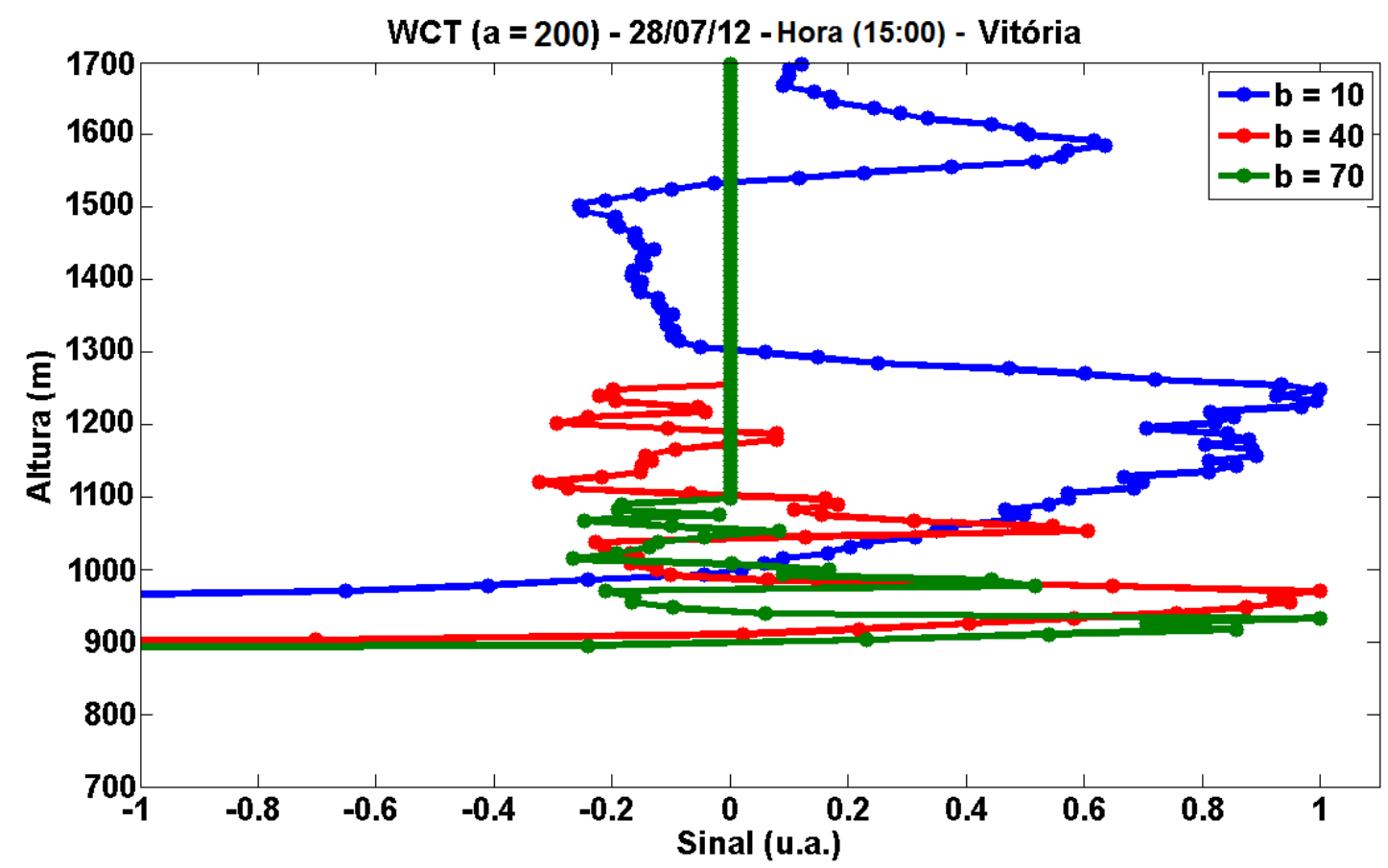

Figura 5.44: Método WCT com variação de "b"

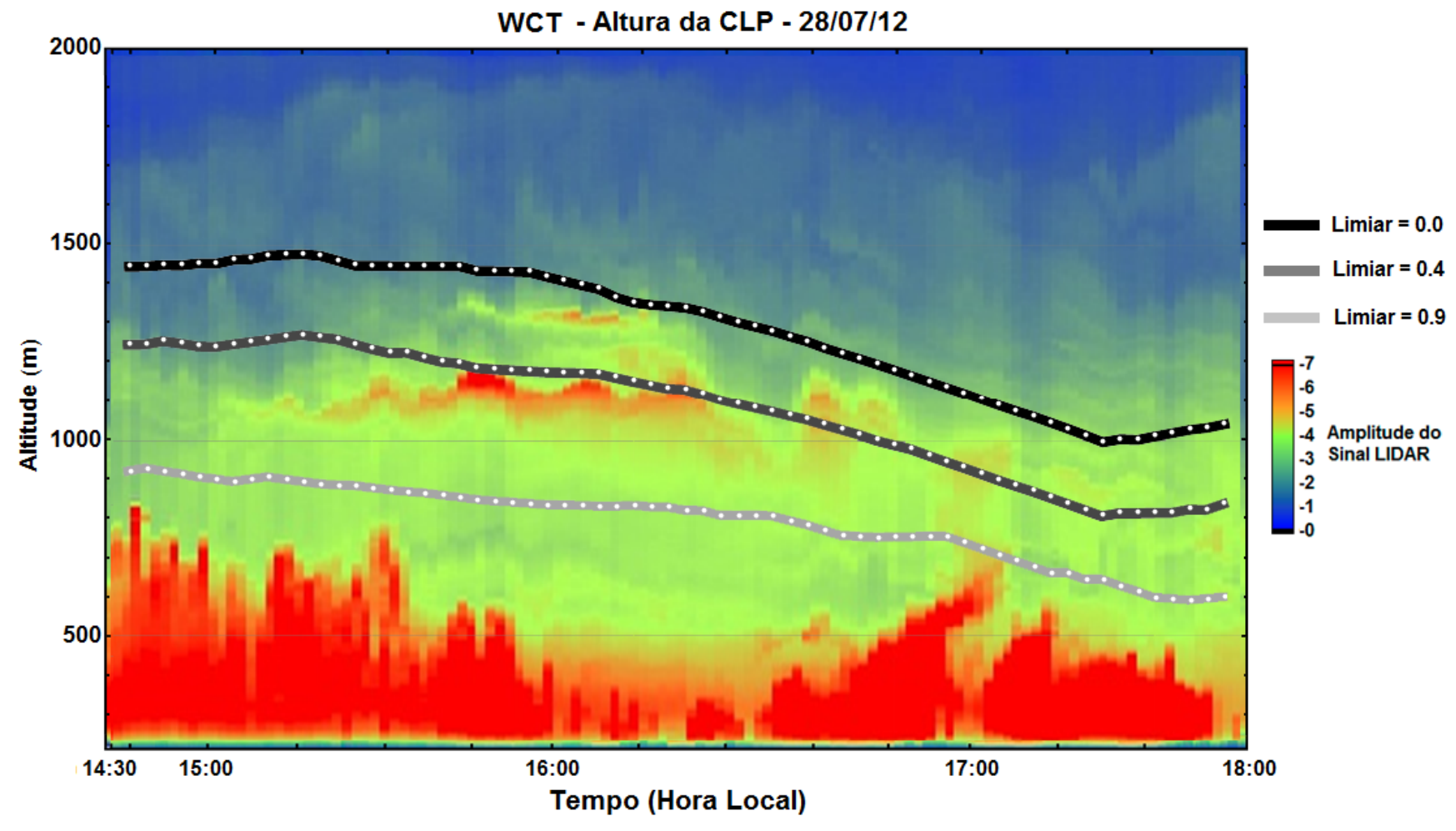

Figura 5.45: Método WCT com variação de limiar 


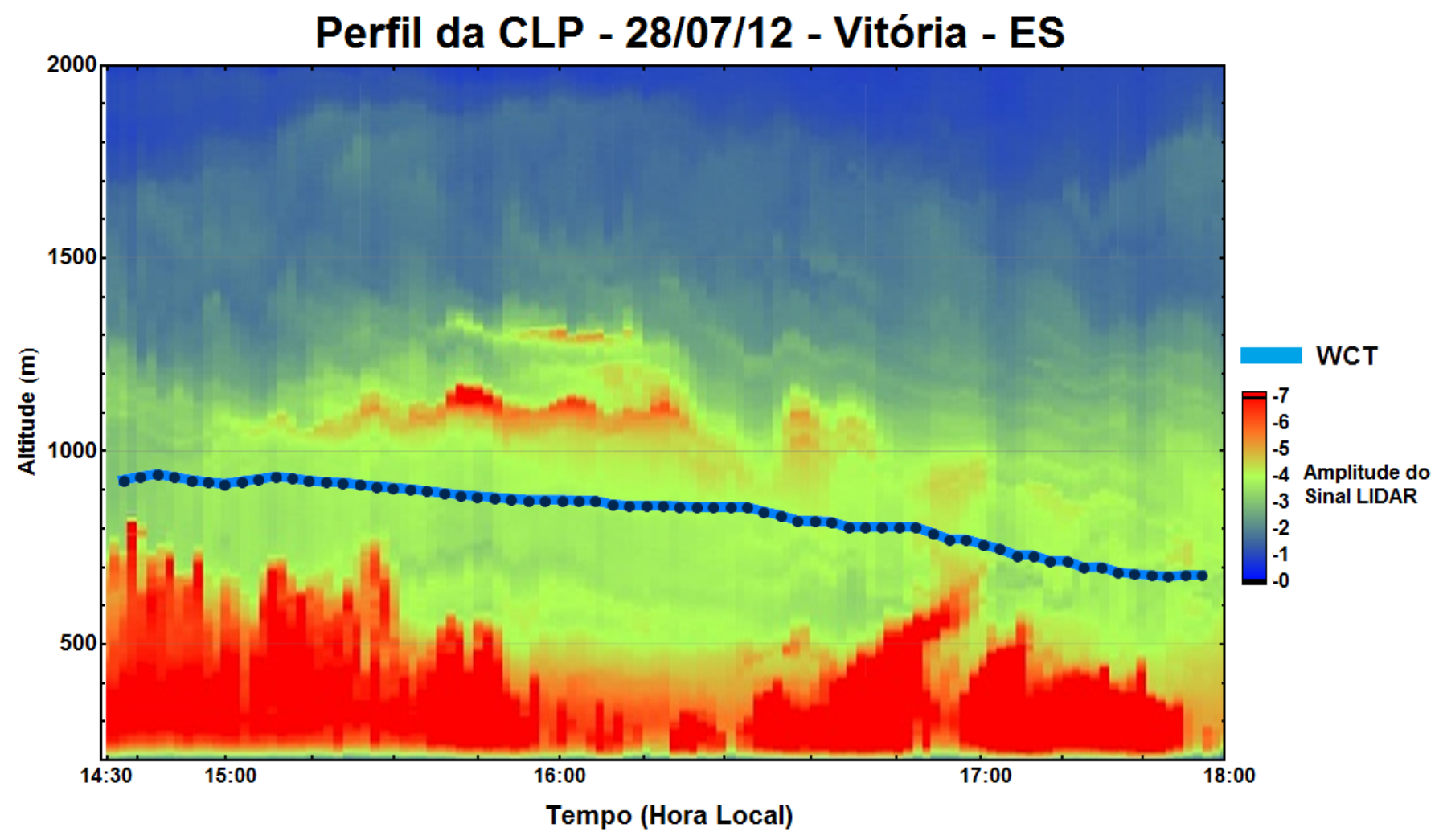

Figura 5.46: Método da WCT

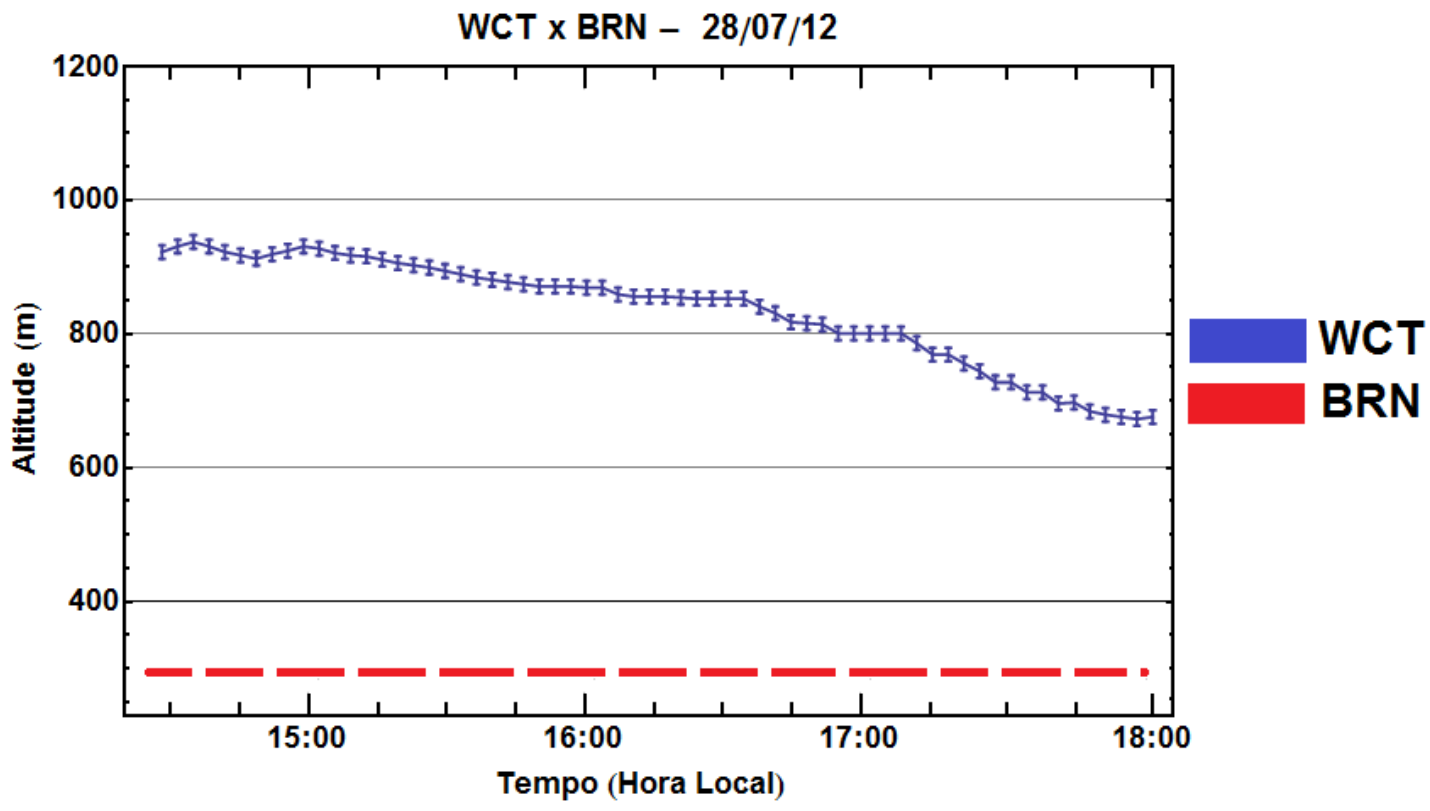

Figura 5.47: Comparação entre o Método WCT e o BRN 


\subsubsection{Avaliação dos métodos para a situação de 'Turbulência'}

A alta concentração das camdas espessas de aerossol aumentam o grau de dificuldade da detecção. Os métodos que não possuem a inserção de limiares (Imagem e Variância) exibem em diversos momentos perfis muito similares ao esperado, porém na presença de nuvens ou espessas subcamadas de aerossol, os mesmos apresentam dificuldades para realizar uma separação efetiva entre a CLP e tais subcamadas.

Os métodos que possuem a inserção de limiares necessitam de um maior cuidado na hora de selecionar o valor correto, e para o WCT, o cuidado torna-se ainda maior, devido a escolha dos parâmetros "a"e "b". Como há necessidade de uma escolha mais refinada para todos os parâmetros, o tempo de processamento acaba se tornando maior.

De uma maneira geral, embora apresentem dificuldades, os métodos conseguem demonstrar parcialmente o perfil da CLP, sendo que os melhores resultados foram do MG e do WCT.

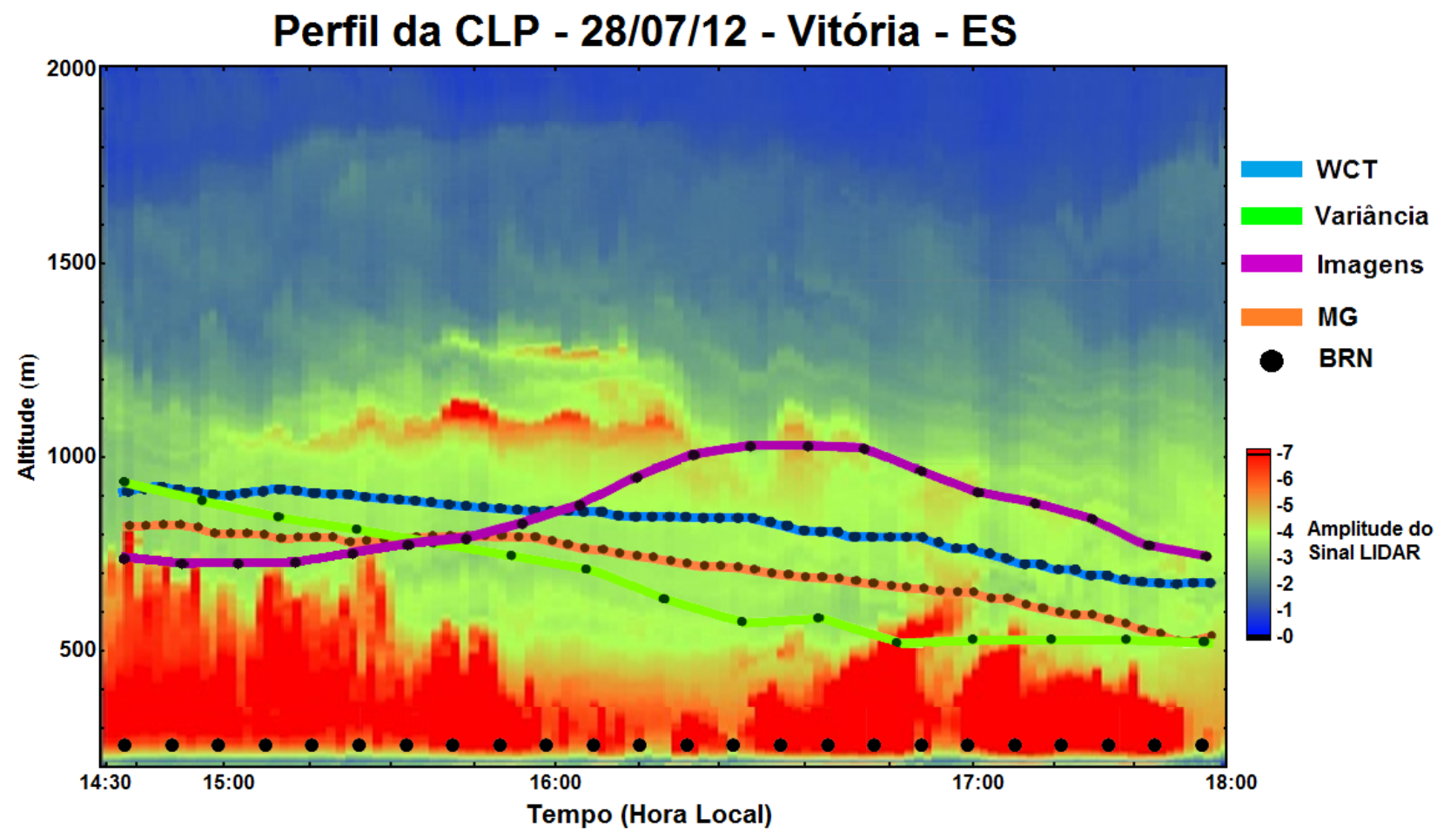

Figura 5.48: Comparação entre os métodos 


\subsection{Medida de 12 horas contínuas}

Nesta segunda parte da Análise será abordada uma medição de 12 horas contínuas, realizada no dia 20 de Fevereiro de 2013, a qual faz parte da campanha MCITY-SP.

O grande diferencial desta situação foi a disponibilização de radiossondagens de alta resolução, as quais foram lançadas a cada três horas (RS1 às 9 horas, RS2 às 12 horas, RS3 às 15 horas, RS4 às 18 horas e RS5 às 21 horas), portanto diferentemente das três situações anteriores não haverá apenas um ponto para o BRN. Isso permitiu a observação da evolução da CLP a partir dos dados de radiossondagem.

Para auxiliar na comparação também foi utilizado o modelo WRF (Weather Research and Forecasting Model), o qual é um sistema de previsão numérica do tempo, criado para proporcionar previsões operacionais e atender as necessidades de pesquisas da atmosfera. Ele possui dois núcleos dinâmicos, um sistema de assimilação de dados, e uma arquitetura de software que permite a computação paralela. A parametrização utilizada será descrita posteriormente.

A fig. 5.49 ilustra o perfil da atmosfera, onde é possível observar: o crescimento da CLP desde as 9:30 até às 14:30 horas, aparecimento de algumas camadas de nuvens a partir das 14 horas e se extendendo até às 18:00 horas, a redução da camada por volta das 17:40 e a presença de uma grande camada de aerossóis a partir das 17 horas, a qual é compactada devido a redução da camada até por volta das 19 horas. Este dia de medida possui a união dos três casos citados anteriormente. 


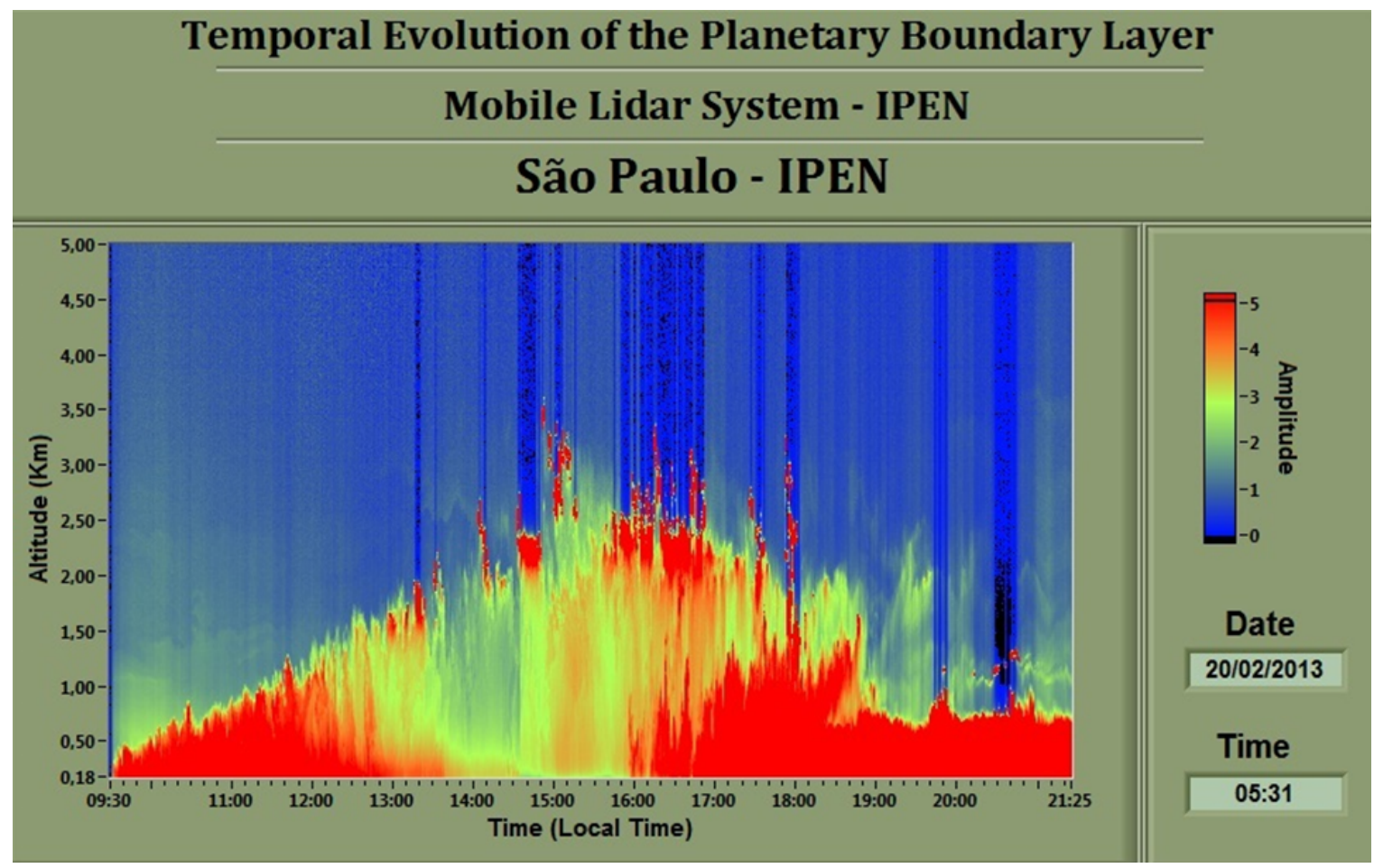

Figura 5.49: Perfil lidar para um medida de 12 Horas 


\subsubsection{Método da Variância aplicado a uma situação de 12 horas contínuas de medição}

Este método apresenta valores condizentes com o resultado esperado (Fig. 5.50), e consegue descrever a ascenção da camada, principalmente nos momentos mais críticos, onde há uma forte presença de nuvens, o mesmo também consegue fazer , de forma muito eficiente, a separação entre as camadas de nuvens e a CLP, o que está de acordo com a literatura [15], a qual afirma que tal método apresenta bons resultados para situações complexas.

A Variância também consegue descrever o decrescimento da CLP, embora com um pouco de dificuldade em alguns momentos e, na parte noturna da medida, esboçar o contorno da camada, ficando acima do esperado apenas na parte onde há uma maior concentração de nuvens.

A Fig. 5.51 mostra a comparação entre os valores obtidos através do BRN

e o método da Variância. É possível observar que embora existam momentos de divergêngia, ao longo do perfil há determinados momentos onde os valores se aproximam, sendo os maiores distanciamentos referentes aos pontos onde há ocorrência de nuvens.

Nesta análise, foi utilizado um conjunto de 30 perfis para a realização da variância e, em seguida realizada a média móvel de um conjunto de 15 pontos, dando ao gráfico final uma resolução temporal cerca de 10 vezes inferior a do Lidar. 


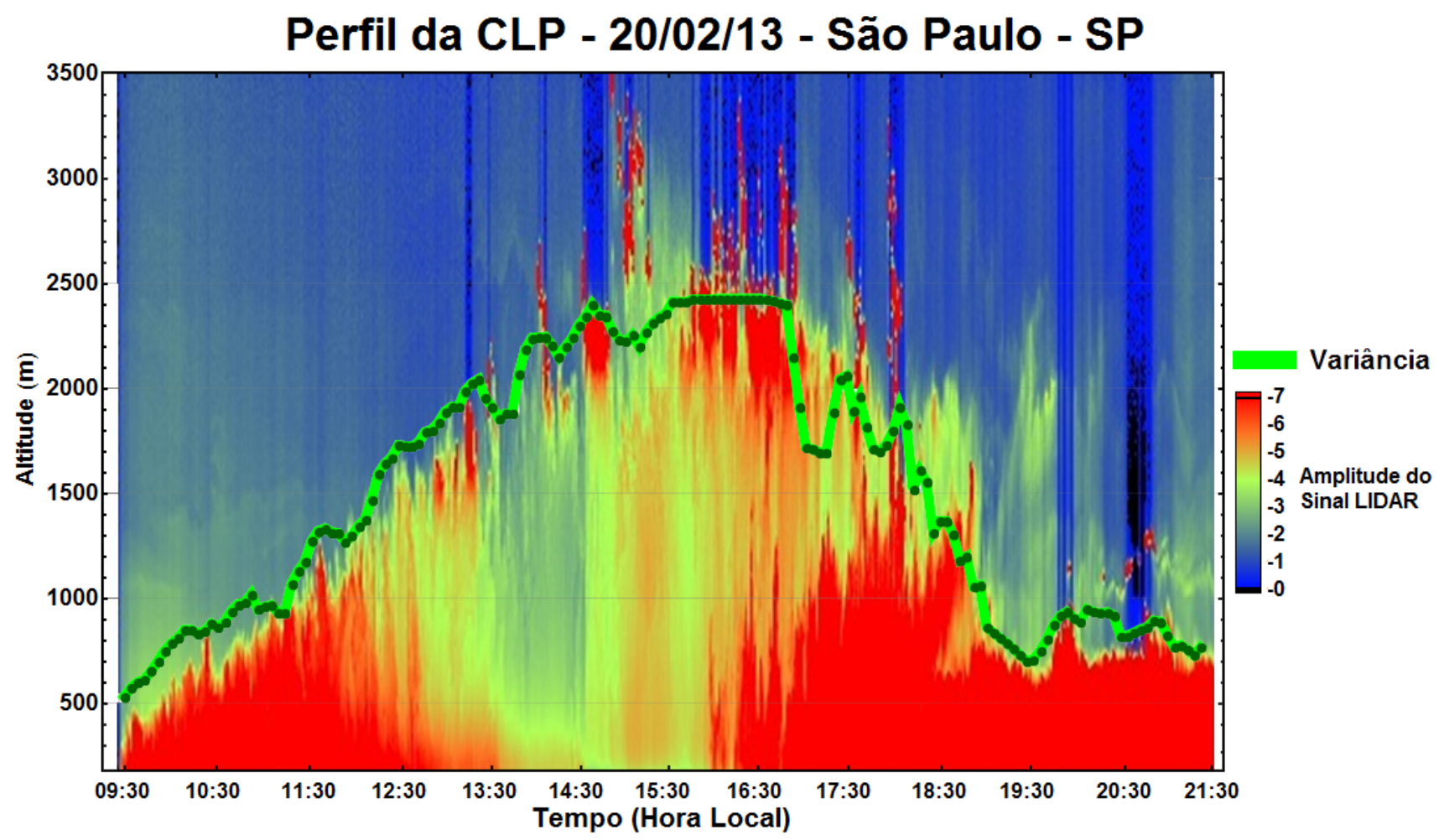

Figura 5.50: Método da Variância

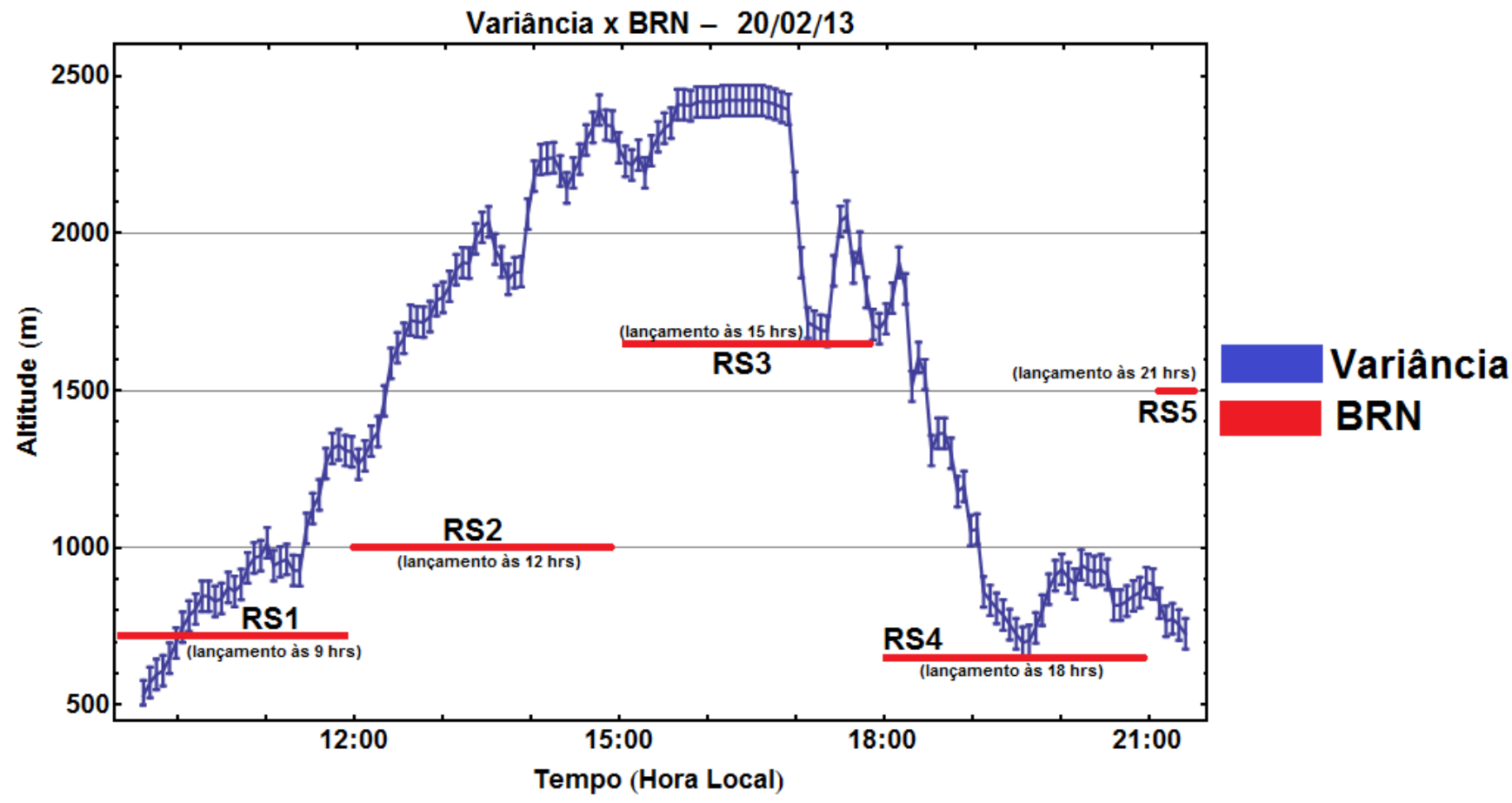

Figura 5.51: Comparação entre o Método da Variância e o BRN 


\subsubsection{Método das Imagens aplicado a uma situação de 12 horas contínuas de medição}

O método das imagens apresenta resultados parcialmente dentro do esperado (Fig. 5.52). O mesmo se destaca na parte inicial da medida, pois embora apresente valores acima do perfil ideal (variando entre 50 e 100 metros), ele consegue reproduzir a ascenção da CLP.

A grande dificuldade deste método está no momento em que passam a surgir nuvens (entre 13:30 e 18:00 horas) e há uma parcial redução na concentração de aerossóis. Neste ponto o mesmo indica uma redução no topo da CLP e passa a oscilar, afastando-se do valor esperado.

$\mathrm{Na}$ parte final da medida, o método consegue representar de forma satisfatória tanto o decrescimento da CLP quanto as oscilações existentes na parte noturna.

Em comparação com o BRN (Fig. 5.53) este é o método que mais se aproxima do mesmo, exibindo as maiores diferenças nos pontos onde há ocorrência de nuvens e na parte noturna.

Assim como nos casos anteriores, para a confecção da curva foi realizada a média móvel para cada conjunto de 5 pontos, dando a figura final uma resolução temporal cerca de 20 vezes inferior a do Lidar. 


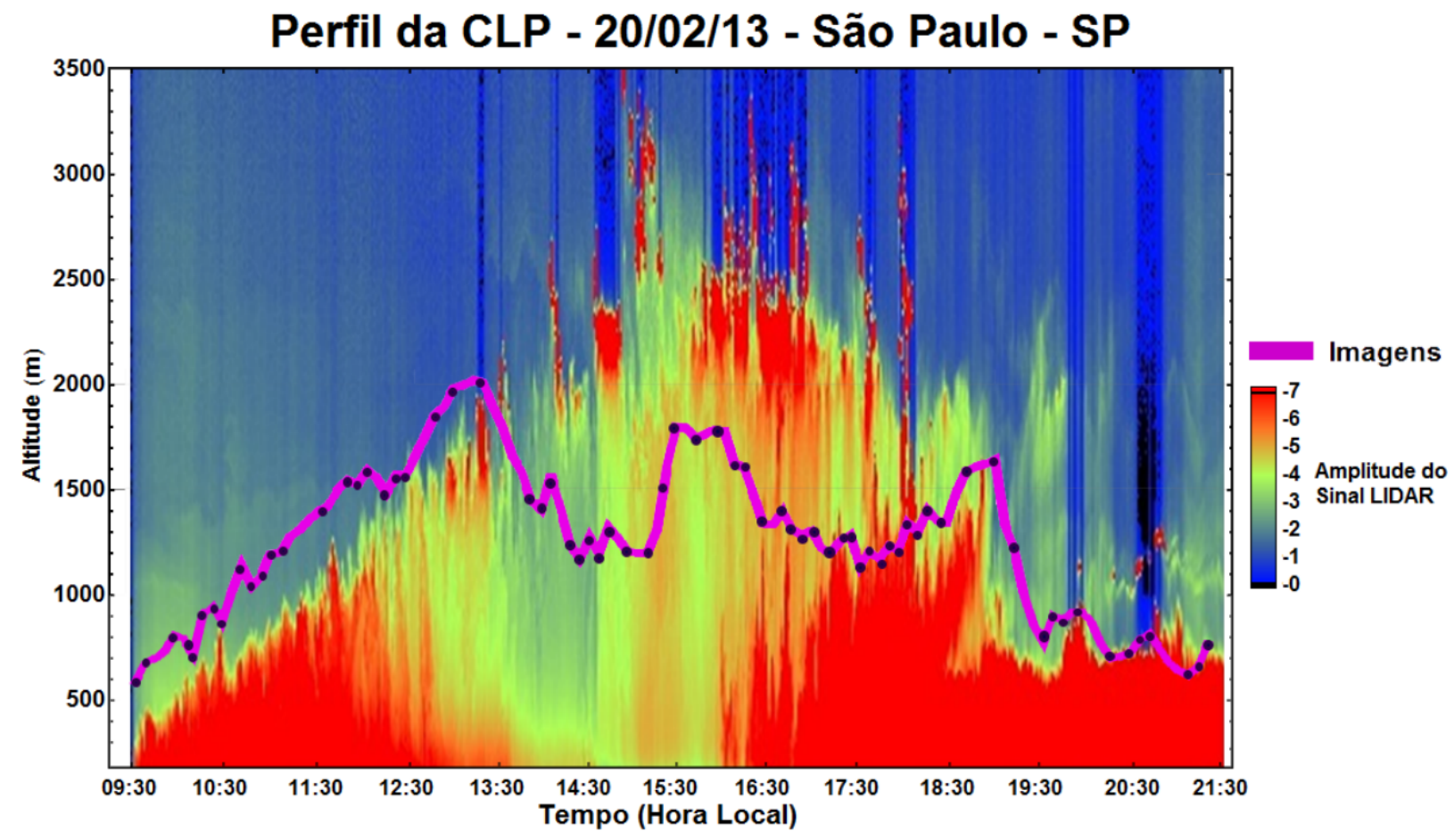

Figura 5.52: Método das Imagens

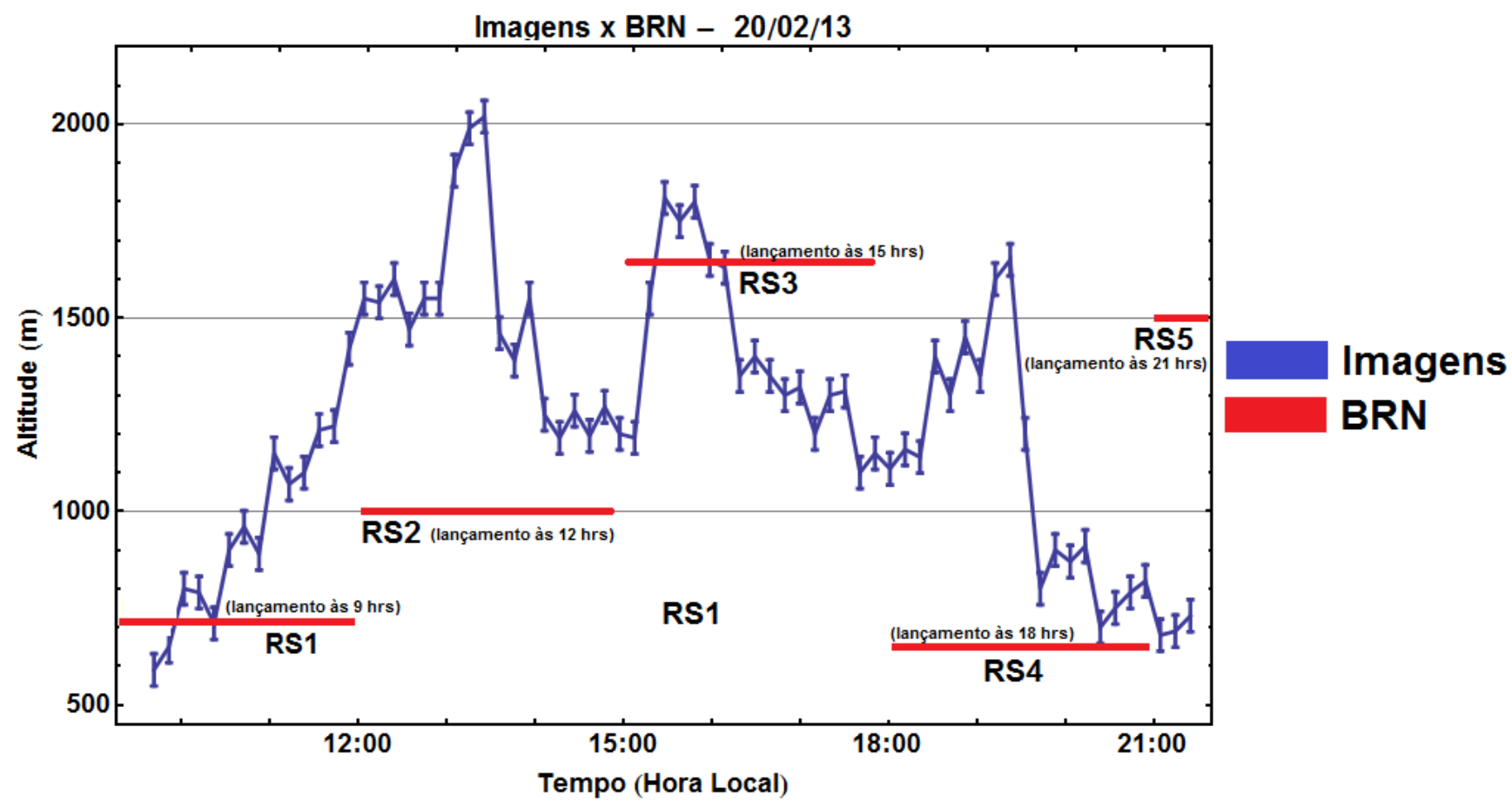

Figura 5.53: Comparação entre o Método das Imagens e o BRN 


\subsubsection{Método do Gradiente aplicado a uma situação de 12 horas contínuas de medição}

O MG representa de forma bastante satisfatória a ascenção da CLP, embora nas primeiras horas apresente um distanciamento que varia de 100 a 150 metros.

Por ele ser um dos métodos mais sensíveis [12, 15, 40], no horário entre 13 e 16 horas, quando há uma redução na concentração de aerossóis, tal método, assim como aconteceu com o método das Imagens, apresenta um acentuado decrescimento na altura da CLP, retomando a ascenção após este período, quando há uma elevação na concentração de aerossóis.

A parte final da curva gerada pelo MG também se mostra um pouco prejudicada, pois a mesma não consegue representar de forma satisfatória o decrescimento da CLP. E na parte noturna após as 18:30, o método não consegue fazer a distinção entre a CLP e a camada de nuvens, dando a primeira um valor acima do esperado.

A curva indicada na Fig. 5.54 foi construída mediante a utilização de um valor de limiar $=-0,6$, pois valores mais baixos geram perda de informações (como por exemplo a ascenção da CLP e, valores mais altos não permitem uma correta distinção entre as nuvens e a CLP na maioria da figura.

A grande sensibilidade também afasta este método dos valores obtidos através do BRN (Fig. 5.55), principalmente nas regiões onde há nuvens.

A resolução temporal da curva é quatro vezes inferior a do Lidar, uma vez que foi realizada a média móvel para conjuntos de 60 pontos. 


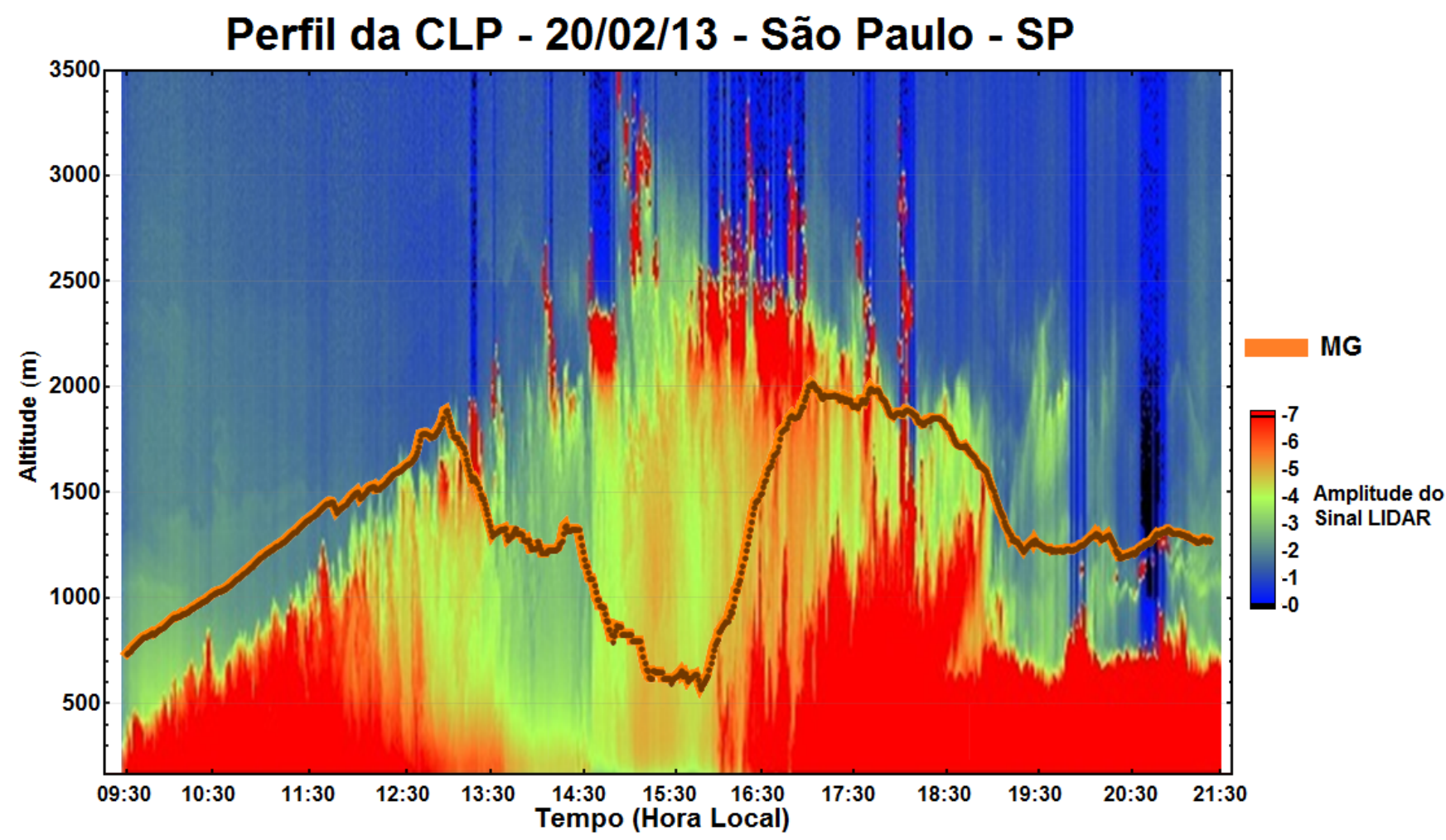

Figura 5.54: Método do Gradiente

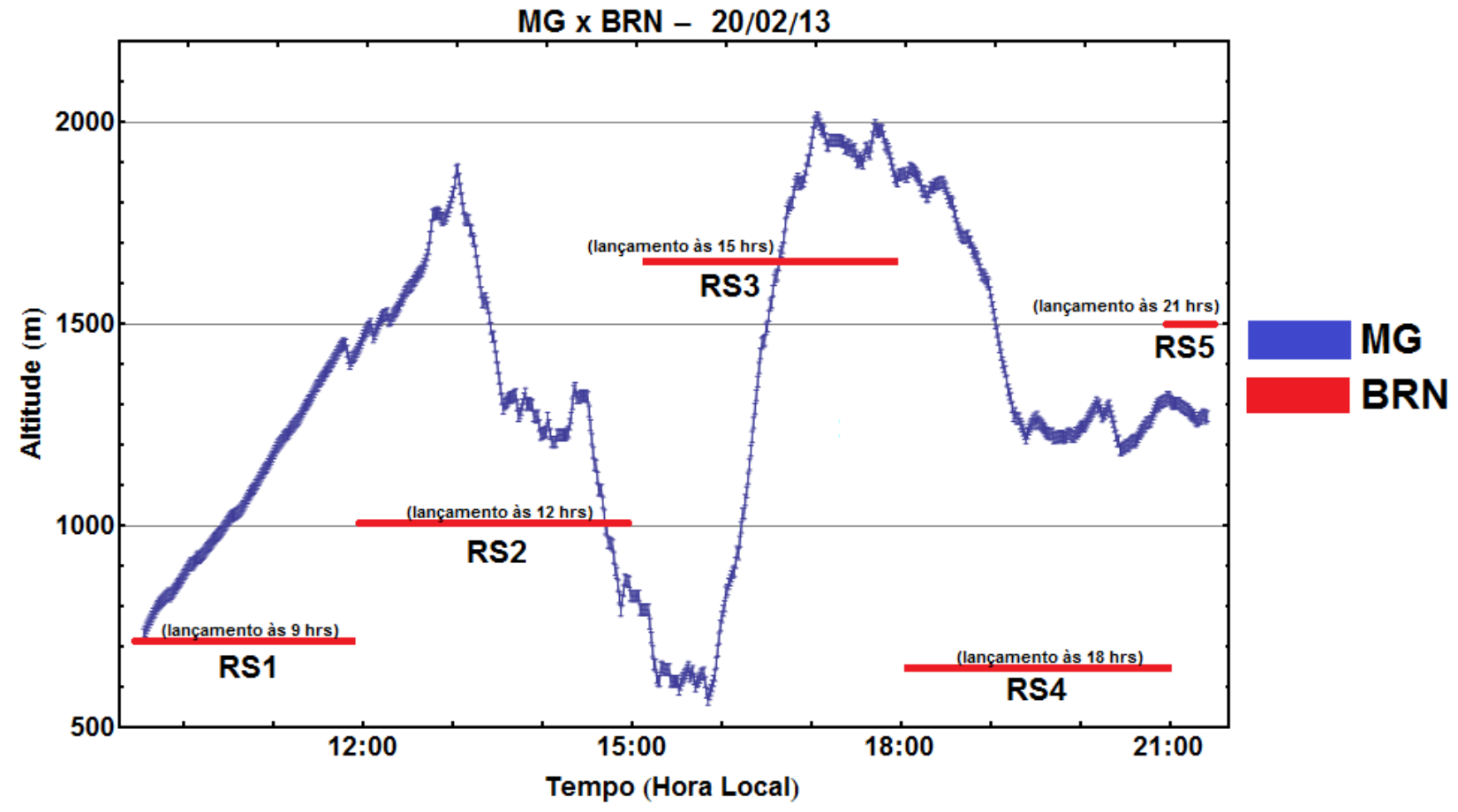

Figura 5.55: Comparação entre o Método do Gradiente e o BRN 


\subsubsection{Wavelet Covariance Transform aplicado a uma situação de 12 horas contínuas de medição}

A escolha de parâmetros para esta análise foi um pouco complexa devido a miscelânea de situações. Foi utilizada uma parametrização que mais se aproxima do caso turbulento, para conseguir alcançar a separação entre nuvens e CLP. Foi adotado $\mathrm{a}=150$, para acentuar os valores de máximo $e, b=50$ para não detalhar muito o gráfico, mas sim para aproximá-lo do perfil ideal. O limiar de 0,6 foi suficiente para auxiliar na filtragem dos dados.

Quanto a resolução temporal, foi realizada a média móvel para cada conjunto de 60 pontos, o que dá a figura final uma resolução temporal 4 vezes inferior a do Lidar.

Esta método demonstra resultados que estão de acordo com o esperado (Fig. 5.56). Ele consegue reproduzir fielmente a ascenção da CLP, apresentando uma diferença inicial que é da ordem de 50 metros, porém esta vai sendo reduzida ao longo do tempo e se aproxima cada vez mais do resultado esperado.

$\mathrm{Na}$ região onde há alta concentração de nuvens, o método consegue realizar a distinção entre a CLP e a camada de nuvens de forma clara.

O decrescimento da camada também está representado de maneira condizente com o esperado. A única divergência ocorre durante aproximadamente 16:30 e 18:00 horas, onde o gráfico passa por uma queda mais acentuada do que a observada pela análise visual.

A parte noturna da camada apresentou um pouco mais de dificuldades de representação, devido a grande quantidade de oscilações e presença de nuvens, porém os resultados apresentados não apresentam grandes divergências do esperado, com exceção do período entre 20 e 21 horas.

Em comparação com o BRN (Fig. 5.57) os resultados apresentados foram parcialmente satisfatórios, sendo que houve grande distanciamento entre ambos durante a ascenção da CLP e na parte noturna da medida. 


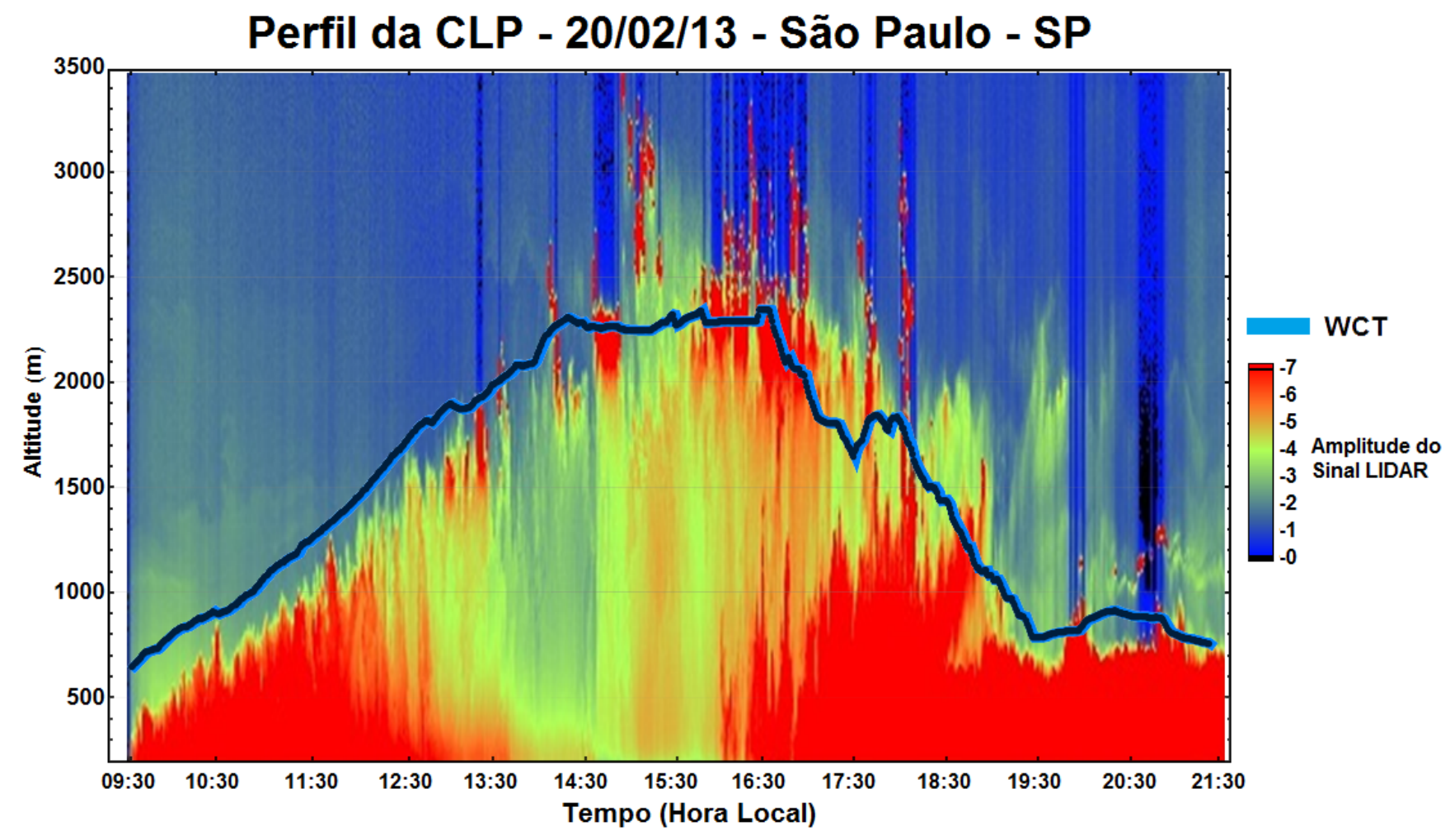

Figura 5.56: Método WCT

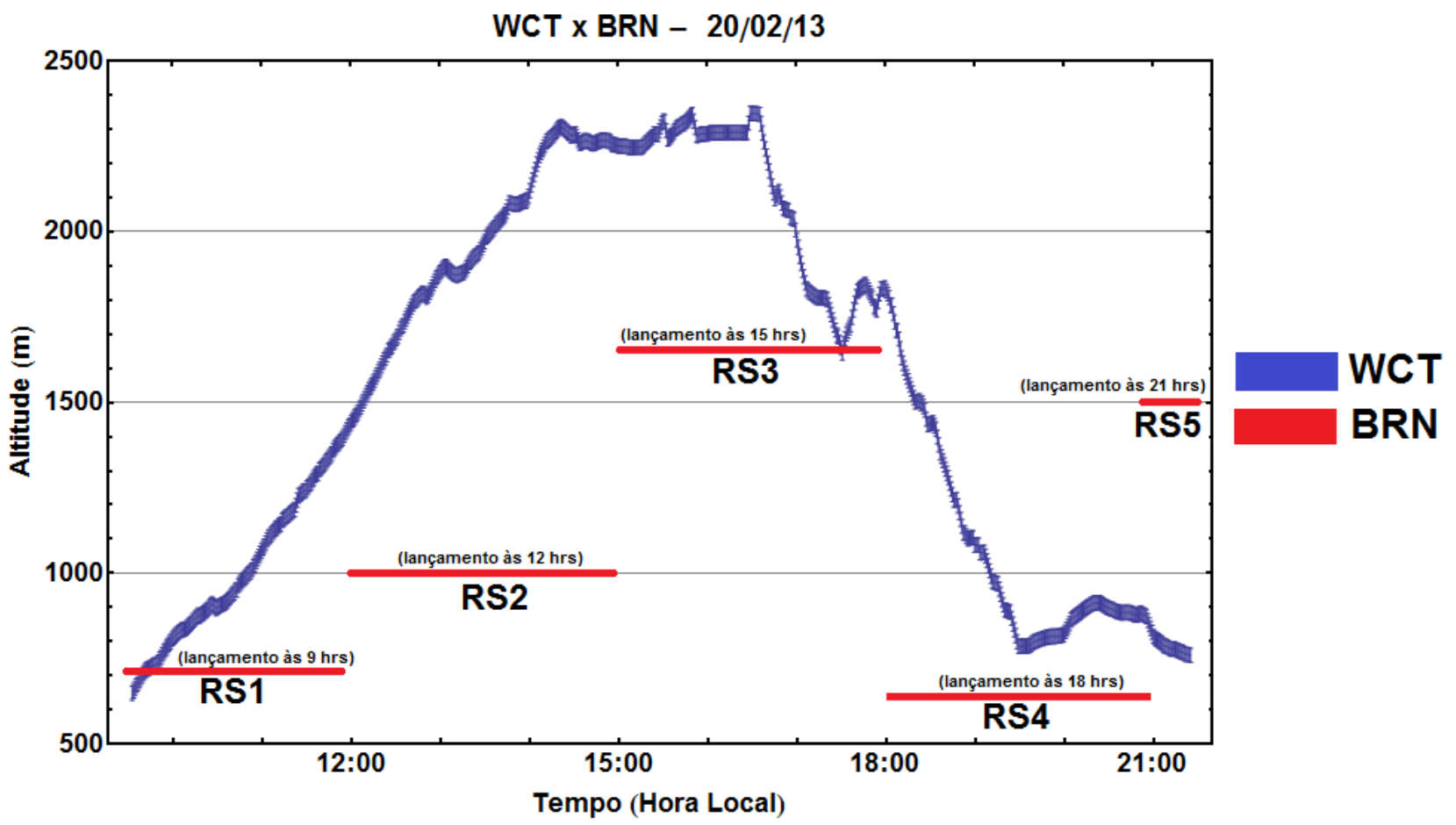

Figura 5.57: Comparação entre o Método WCT e o BRN 


\subsubsection{Weather Research and Forecasting - WRF Model}

Tal modelagem foi realizada em conjunto com o Profo Nadir Salvador da UFES. O período escolhido corresponde aos dias 19 a 22 de Fevereiro, onde foram utilizandos quatro domínios aninhados (d1, d2, d3, d4), sendo os 3 primeiros: quadrados e com lados de 1863 km, 891 km e 594 km, respectivamente. O último (d4) corresponde há um retângulo com dimensões de $81 \mathrm{~km}$ no sentido norte-sul e $63 \mathrm{~km}$ no sentido leste-oeste. Todos os quatro domínios foram centrados nas coordenadas (-23,562 ; -46,738), as quais representam a posição do Lidar no prédio do CLA - IPEN. Para cada domínio aplicou-se, repectivamente, as seguintes grades: 27 km, 9 km, 3 km e 1 $\mathrm{km}$.

Foram utilizados 43 níveis verticais mais concentrados próximos ao solo, sendo 32 níveis até $1600 \mathrm{~m}$, de forma a facilitar a comparação com valores medidos, evitando maiores distorções que ocorrem em interpolações. Para a CLP foi utilizada a parametrização Asymmetric Convective Model 2 (ACM2), a qual faz um tratamento anisotrópico da turbulência.

A parametrização ACM2 é de fechamento não local e inclui um componente de difusão turbulenta de primeira ordem em adição ao esquema original (ACM1) de transporte explícito não local, com isso há uma melhora na forma do perfil vertical próximo à superfície [37, 38], gerando portanto uma modelagem realista e computacionalmente eficiente da CLP para uso tanto em modelos meteorológicos quanto nos de química atmosfera. A técnica chave do ACM2 está em combinar os dois regimes (ACM1 e difusão turbulenta)a uma certa altura, sendo neste caso, o topo da camada mais baixa do modelo, e repartir a razão de mistura entre os dois regimes de modo que o fluxo resultante a essa altura seja idêntico ao produzido por qualquer um dos dois sendo executado sozinho.

Para a Camada Superficial do Solo foi selecionada a parametrização Pleim-Xiu, a qual inclui a umidade do solo explícita que se baseia em um modelo de interação entre solo, biosfera e atmosfera, considerando a evaporação do solo, do dossel e a evapotranspiração da cobertura vegetal, incluindo uma simulação de variação sazonal 
da vegetação [36, 9].

As tabelas 5.1 e 5.2 descrevem as demais características e parametrizações utilizadas pelo WRF.

Tabela 5.1: Parametros Temporais utilizados no WRF

\begin{tabular}{|c|c|}
\hline \multicolumn{2}{|c|}{ Parametros Temporais utilizados no WRF } \\
\hline Data Inicial & 19/02/13 as 00 UTC \\
\hline Data Final & 22/02/13 as 00 UTC \\
\hline Duração & 72 Horas \\
\hline \multicolumn{2}{|c|}{ Opções Físicas e Dinâmicas - WRF v. 3.2.1 } \\
\hline Microfísica & Thompson (d1) - WSM6 (d2, d3, d4) \\
\hline Radiação de Onda Longa & RRTM \\
\hline Radiação de Onda Curta & Dudhia \\
\hline Camada - Superfície & Pleim - Xu \\
\hline Superfície - Terra & Pleim - Xu \\
\hline Camada Limite & ACM2 (Pleim) \\
\hline Cúmulos & New Grell (d1, d2) - Betts Miller (d3) - 0 (d4) \\
\hline Camadas do Solo & Modelo de Superfície de Pleim - Xu \\
\hline Difusão, Dissipação, Advecção & $3^{a}$ Ordem Runge-Kutta \\
\hline Turbulência e Mistura & Termo de Difusão de $2^{a}$ Ordem \\
\hline Coeficiente Eddy & Esquema de $1^{\text {a }}$ Ordem Smagorinsk \\
\hline
\end{tabular}

Tabela 5.2: Parâmetros Espaciais utilizados no WRF

\begin{tabular}{|l||c|c|c|c|}
\hline \multicolumn{5}{|c|}{ Valores atribuídos aos Parâmetros } \\
\hline \hline Nome da Parametrização & $\mathrm{d} 1$ & $\mathrm{~d} 2$ & $\mathrm{~d} 3$ & $\mathrm{~d} 4$ \\
\hline \hline Pleim-Xiu Surface Layer & 7 & 7 & 7 & 7 \\
\hline Pleim-Xiu Land Surface Model & 7 & 7 & 7 & 7 \\
\hline ACM2 PBL & 7 & 7 & 7 & 7 \\
\hline \hline \multicolumn{4}{|c|}{ Parâmetros Espaciais utilizados no WRF } \\
\hline \hline Resolição das Grades & $27 \mathrm{Km}$ & $9 \mathrm{Km}$ & $3 \mathrm{Km}$ & $1 \mathrm{Km}$ \\
\hline Número de Colunas & 70 & 100 & 100 & 82 \\
\hline Número de Linhas & 70 & 100 & 100 & 84 \\
\hline Número de Camadas Verticais & 43 & 43 & 43 & 43 \\
\hline
\end{tabular}

A Fig. 5.58 mostra os valores obtidos para a CLP a partir do WRF, em comparação com o perfil gerado através dos dados do lidar.

Embora com algumas divergências, os valores obtidos a partir do WRF para a CLP se mostram próximos dos indicados pela análise visual do perfil lidar, principalmente 


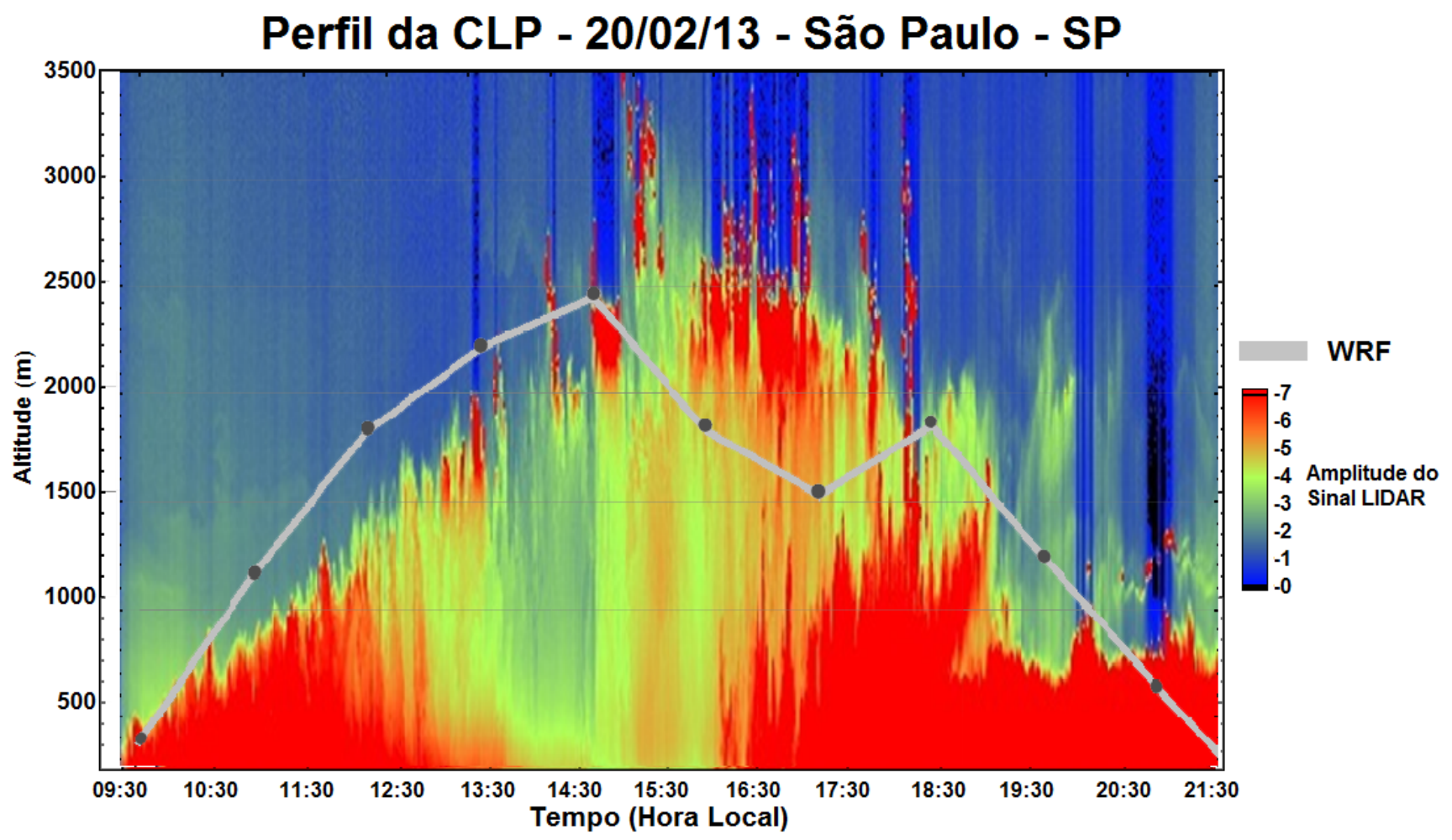

Figura 5.58: WRF

na parte inicial (ascenção da camada) e no início da noite durante o declínio da camada. As maiores divergências surgem entre 14:30 e 18:30, momento em que há uma diluição na concentrações de aerossóis e a camada se extende. 


\subsubsection{Avaliação dos Métodos para uma situação de 12 horas contínuas de medição}

Dentro de suas limitações os métodos conseguiram atender de forma satisfatória grande parte do desenvolvimento da CLP ao longo das 12 horas de medidas.

Na parte inicial, onde ocorre a ascenção da CLP, todos os 4 métodos utilizados descrevem perfis muito próximos do esperado, sendo acompanhados pelo WRF. O BRN, embora apresente um certo distanciamento do métodos, também mostra tal ascenção.

As maiores disparidades começam a surgir por volta das 13 horas, onde dois eventos importantes acontecem: o surgimento de nuvens e a redução na concentração de aerossóis. Com isso, os métodos mais sensíveis, MG e Imagens, começam a declinar, sendo que o último passa apenas por algumas oscilações, enquanto o primeiro apresenta uma queda brusca que perdura até por volta das 16 horas, ponto onde a curva passa a ter uma nova ascenção. Neste intervalo, o WRF também apresenta algumas oscilações e indica uma redução na altura da CLP.

Entre 18 e 18:30 horas, todos os métodos voltam a se encontrar e exibem perfis que indicam a redução da CLP, o que está de acordo com os resultados apresentados, tanto pelo BRN quanto pelo WRF, embora o último demonstre um decrescimento mais acentuado.

Durante a noite, apenas o MG exibe um perfil que está muito divergente do esperado, pois o mesmo não consegue diferenciar o topo da CLP da camada gerada pelas nuvens. Os outros três métodos, embora não consigam representar fielmente o pefil da CLP, geram valores muito próximos do esperado. A curva gerada pelo WRF coincide com os gráficos gerados pelos métodos em alguns pontos, porém, por volta das 21:30 horas, a mesma indica uma redução da camada para valores abaixo de 200 metros.

Dentre todos os métodos o das Imagens é o que mais se aproxima dos valores fornecidos pelo BRN, enquanto o WCT e a Variância são os que mais se aproximam da análise visual e do WRF (Fig. 5.58). 


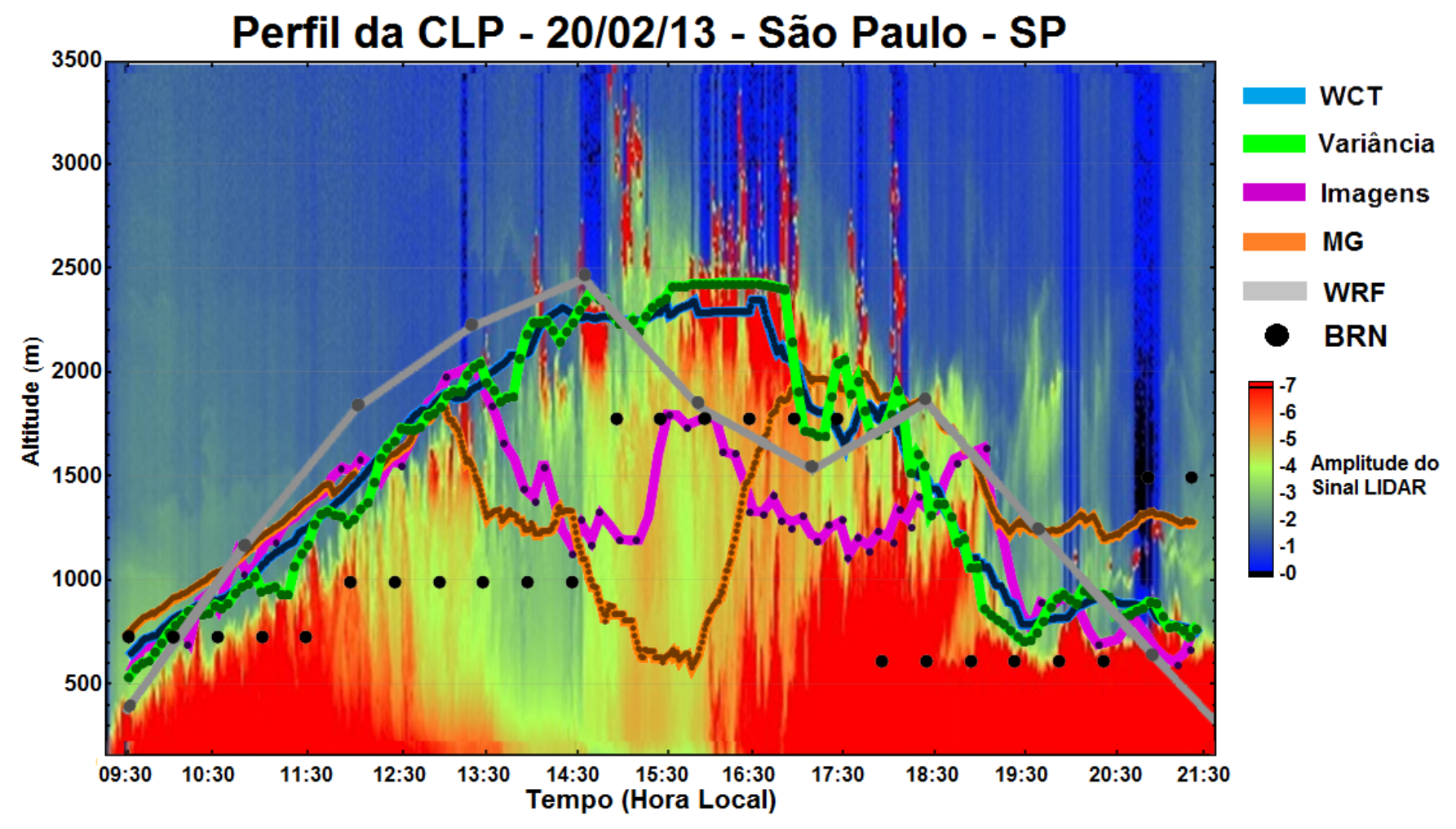

Figura 5.59: Comparação entre os métodos 


\section{Capítulo 6}

\section{Conclusão}

Uma sólida compreensão dos fenômenos físico-químicos que ocorem na CLP, é fundamental para o entendimento da dinâmica atmosférica, além de prevenção e mitigação de eventos relacionados a poluição do ar. No entanto para isso é fundamental a comprensão dos processos dinâmicos envolvidos e a determinação de parâmetros relevantes, tal como a altura média da CLP, velocidade do vento e a taxa de entranhamento [26].

A realização deste trabalho propiciou a obtenção de uma melhor compreensão sobre os diversos fatores que atuam na dinâmica da CLP e a observação de como o sistema lidar pode auxiliar no estudo da mesma. Ao longo de todo o processo também foi possível compreender melhor o funcionamento do sistema lidar.

Todos os métodos mostraram suas vantagens e desvantagens ao longo das mais variadas situações, pois a partir do estudo de casos foi possível observar que dependendo do problema e da resposta necessária, deve-se utilizar um determinado método.

Para qualificar os métodos foram utilizadas gradações que variam de 1 a 5 (1 Muito Baixo, 2 - Baixo, 3 - Médio, 4 - Alto e 5 - Muito Alto) e foram escolhidos três parâmetros:

- Tempo de Processamento: tempo necessário para que o computador execute completamente o algoritmo. A gradação segue a seguinte tabela: 
Tabela 6.1: Tempo de Processamento

\begin{tabular}{|c|c|}
\hline \multicolumn{2}{|c|}{ Gradação para Tempo de Processamento } \\
\hline \hline Tempo de Processamento & Gradação \\
\hline$<1$ minuto & 1 \\
\hline $1-2$ minutos & 2 \\
\hline 2 - 3 minutos & 3 \\
\hline $3-4$ minutos & 4 \\
\hline$>5$ minutos & 5 \\
\hline
\end{tabular}

- Parâmetros: representa a dificuldade encontrada para a escolha dos parâmetros que fornecem os melhores resultados. A gradação é dada a partir do número de iterações realizadas, conforme mostra a tabela 6.2:

Tabela 6.2: Dificuldade para a escolha de Parâmetros

\begin{tabular}{|c|c|}
\hline \multicolumn{2}{|c|}{ Gradação para Parâmetros } \\
\hline \hline Número de Iterações & Gradação \\
\hline 1 & 1 \\
\hline $2-4$ & 2 \\
\hline $4-6$ & 3 \\
\hline $6-8$ & 4 \\
\hline$>9$ & 5 \\
\hline
\end{tabular}

- Resultados: indica a proximidade dos resultados fornecidos por cada método, com relação aos valores adotados como padrão (BRN, Análise Visual e WRF). A tabela a seguir mostra a gradação utilizada:

Tabela 6.3: Proximidade dos resultados com relação ao valor adotado como padrão

\begin{tabular}{|c|c|}
\hline \multicolumn{2}{|c|}{ Gradação para Resultados } \\
\hline \hline Proximidade do Resultado & Gradação \\
\hline$<30 \%$ & 1 \\
\hline $31 \%-50 \%$ & 2 \\
\hline $51 \%-69 \%$ & 3 \\
\hline $70 \%-85 \%$ & 4 \\
\hline$>85 \%$ & 5 \\
\hline
\end{tabular}


Para as situações de "calmaria", onde o perfil da atmosfera se mostra mais simplificado, com exceção da Variância, todos os outros métodos podem ser aplicados e fornecerão resultados satisfatórios. No entanto para análises mais rápidas é recomendado o método das Imagens, devido ao baixo tempo de processamento e simplicidade de aplicação. Os métodos que dependem de parâmetros (MG e WCT) não exigem grande refinamento na escolha dos mesmos, sendo a escolha do limiar o fator mais crítico. A tabela 6.4 exibe de forma comparativa a performance dos 4 métodos.

Tabela 6.4: Situação de Calmaria

\begin{tabular}{|l||c|c|c|}
\hline \multicolumn{4}{|c|}{ Comparação entre os métodos para a situação de 'Calmaria' } \\
\hline \hline Métodos & Tempo de Processamento & Parâmetros & Resultados \\
\hline Variância & 2 & 1 & 2 \\
\hline Imagem & 1 & 1 & 4 \\
\hline MG & 2 & 1 & 4 \\
\hline WCT & 2 & 1 & 5 \\
\hline
\end{tabular}

Em situações onde há presença de subcamadas de aerossóis e/ou nuvens a qualidade dos resultados apresentados pelos métodos decai, com exceção da Variância que passa a apresentar resultados mais próximos do esperado, devido a maior complexidade apresentada pelo sinal lidar.

O WCT se mostra o mais robusto que dentre os métodos, porém exige um certo cuidado para a escolha correta dos parâmetros (sendo ideal a utilização de valores altos para "a"e os menores possíveis para "b"), o que ocasiona aumento no tempo processamento.

A tabela 6.5 exibe um resumo comparativo entre a performance dos 4 métodos para o caso citado acima.

No caso turbulento, todos os métodos passam a apresentar maiores dificuldades 
Tabela 6.5: Situação de Presença de subcamadas de aerossóis e/ou camadas de nuvens

\begin{tabular}{|l||c|c|c|}
\hline \multicolumn{4}{|c|}{ Comparação entre os métodos para o caso de subcamadas de aerossóis e/ou nuvens } \\
\hline \hline Métodos & Tempo de Processamento & Parâmetros & Resultados \\
\hline Variância & 2 & 1 & 3 \\
\hline Imagem & 1 & 1 & 2 \\
\hline MG & 2 & 2 & 3 \\
\hline WCT & 3 & 3 & 4 \\
\hline
\end{tabular}

para detectar corretamente a CLP, e o WCT se mostra o mais robusto, porém exige uma complexa escolha de parâmetros (altos valores para "a"e medianos para "b") e um alto tempo de processamento. O método da Variância embora não apresente resultados tão próximos do esperado quanto o WCT, pode ser uma alternativa devido a sua simplicidade de aplicação e baixo tempo de processamento.

A tabela 6.6 exibe um resumo comparativo entre a performance dos 4 métodos para uma situação de turbulência.

Tabela 6.6: Situação de Turbulência

\begin{tabular}{|l||c|c|c|}
\hline \multicolumn{3}{|c|}{ Comparação entre os métodos para a situação de 'Turbulencia' } \\
\hline \hline Métodos & Tempo de Processamento & Parâmetros & Resultados \\
\hline Variância & 2 & 1 & 3 \\
\hline Imagem & 1 & 1 & 2 \\
\hline MG & 3 & 3 & 4 \\
\hline WCT & 5 & 5 & 5 \\
\hline
\end{tabular}

A medida de 12 horas contínuas representa a combinação das três situações citadas nos estudos de casos em uma única medida, devido a diversidade de eventos que ocorrem. Para esta medida a validação a partir da radiossondagem foi mais efetiva, uma vez que ao invés de utilizar apenas duas sondagens (00 e 12 UTC), foi lançada uma radiossonda a cada três horas. A utilização do WRF também auxiliou para enriquecer a validação dos métodos. 
Todos os métodos conseguem representar satisfatoriamente a ascensão e o decaimento da CLP, ficando as maiores divergências para o meio do dia, principalmente quando há dispersão dos aerossóis gerando atenuação no sinal.

Os métodos mais eficientes são o WCT e a Variância, sendo que o primeiro citado exige um alto tempo de processamento devido a complexidade na escolha dos parâmetros. A tabela 6.7 mostra a comparação entre os resultados apresentados pelos 4 métodos:

Tabela 6.7: Situação de 12 Horas Contínuas

\begin{tabular}{|l||c|c|c|}
\hline \multicolumn{4}{|c|}{ Comparação entre os métodos para 12 Horas Contínuas de medida } \\
\hline \hline Métodos & Tempo de Processamento & Parâmetros & Resultados \\
\hline Variância & 2 & 1 & 5 \\
\hline Imagem & 1 & 1 & 4 \\
\hline MG & 3 & 3 & 4 \\
\hline WCT & 5 & 5 & 5 \\
\hline
\end{tabular}

Os resultados obtidos neste trabalho condizem com os apresentados pela literatura científca, permitindo assim que para um projeto futuro possa ser implementada a automatização na detecção da altura máxima da CLP mediante a utilização do sistema lidar. Isto possibilitará a obtenção de resultados imediatos e permitirá um melhor acompanhamento da dinâmica da CLP, sendo que para aplicação de tal procedimento o método mais adequado é o WCT, devido aos resultados apresentados. 


\section{Apêndice A}

\section{Sodar}

O SODAR (SOnic Detection And Ranging) é um equipamento de sensoriamento remoto capaz de mensurar a estrutura vertical de turbulência e o perfil dos ventos da baixa atmosfera. O seu princípio físico de funcionamento é o mesmo do radar, porém ao invés de ondas de rádio são utilizadas ondas sonoras, as quais têm a sua intensidade e frequência analisadas[3].

Existem dois tipos principais de sodar:

- Monoestático: utiliza a mesma antena para emitir e receber sinais com pulsos contínuos, sendo de $180^{\circ}$ o ângulo entre os vórtices e antena do sodar. Este modelo possui o design mais simples e prático do que o biestático[3].

- Biestático: as antenas de transmissão e recepção estão em locais diferentes. Isto faz com que o ângulo entre os vórtices e a antena seja diferentes de $180^{\circ}$, possibilitando a detecção da turbulência tanto mecânica quanto térmica, o que gera um sinal mais continuo e mais forte do que o do modelo monoestático[3].

Quando um pulso acústico é transmitido através da atmosfera e este encontra uma descontinuidade na atmosfera (diferença de temperatura, umidade, etc), sua energia é espalhada em todas as direções. Embora existam diferentes padrões de espalhamento resultantes de turbulência térmica e mecânica, parte da energia acústica é sempre refletida, retornando na direção da fonte sonora. A energia retroespalhada pode ser medida mediante a utilização de um sistema sodar 


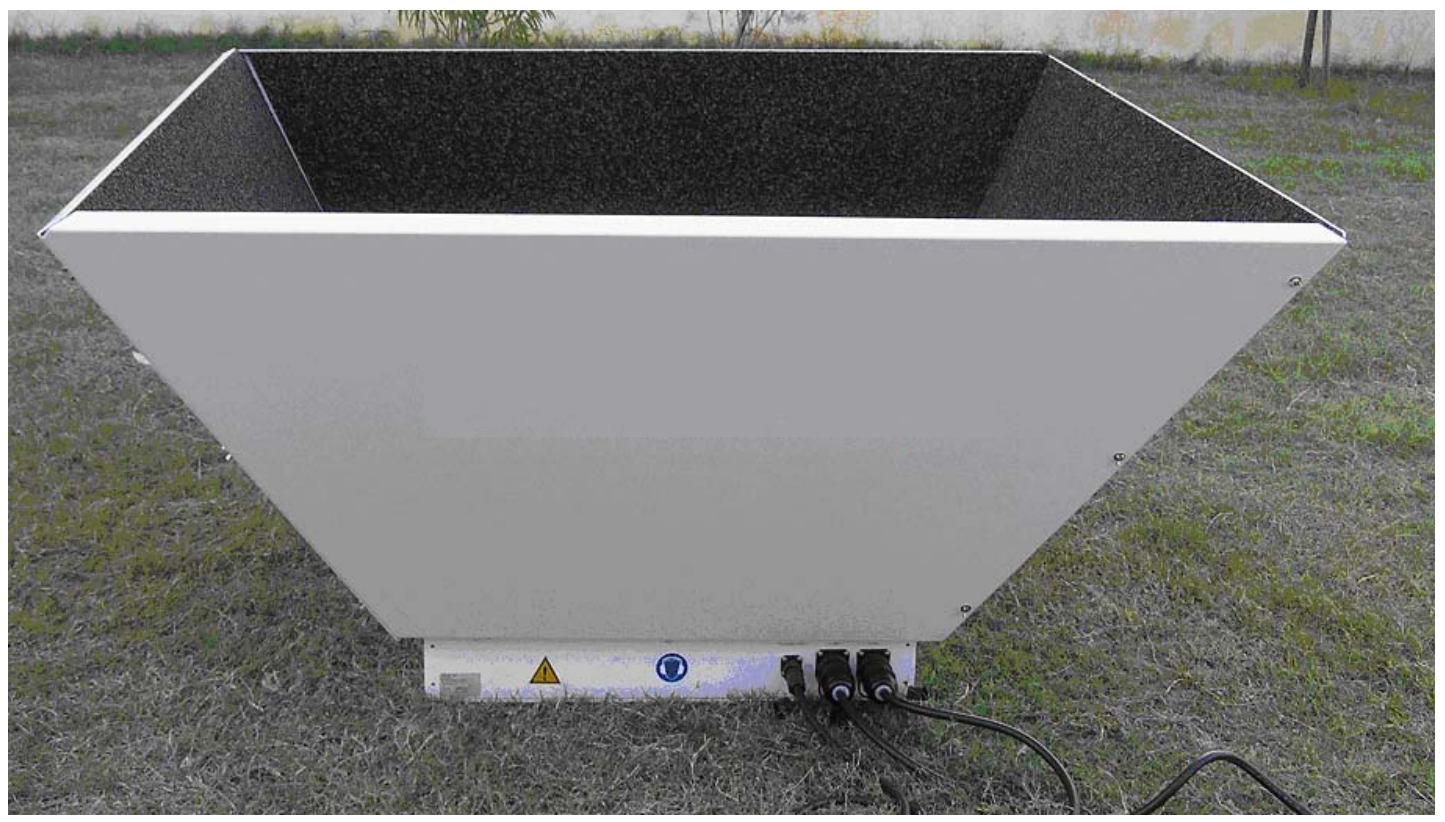

Figura A.1: Sodar Monoestático

monoestático[3].

Devido ao efeito Doppler, quando o alvo (um vórtice turbulento) esta se movendo na direção da antena do sodar, a frequência do sinal de retorno retroespalhado irá ser maior que a frequência do sinal transmitido. Reciprocamente, quando o alvo está se afastando da antena, a frequência do sinal de retorno será menor. Estas mudanças na frequência do sinal captado com relação a frequência do sinal transmitido, possibilitam a obtenção dos parâmetros do vento e das características da turbulência. Informações adicionais podem ser obtidas pela transmissão consecutiva de pulsos na vertical e nas duas ou mais direções ortogonais inclinadas levemente para a vertical. Cálculos geométricos podem então ser empregados para obter perfis verticais da direção do vento, e vertical e horizontal da direção e velocidade do vento[3].

Um sistema sodar recebe e transmite sinais acústicos dentro de uma específica frequência de banda. Sendo assim, qualquer ruído de fundo dentro desta frequência pode afetar o sinal de repetição. Um exemplo de interferência é a alteração no valor da altura máxima obtida pelo sodar, o qual é inferior ao que seria obtido na ausência de ruídos. Portanto, determinadas fontes de ruídos podem inviabilizar a captação de dados através do sodar, sendo importante identificar os potenciais das fontes ruidosas e estimar o nível de ruído de fundo quando for escolher um local para o sodar[3]. 


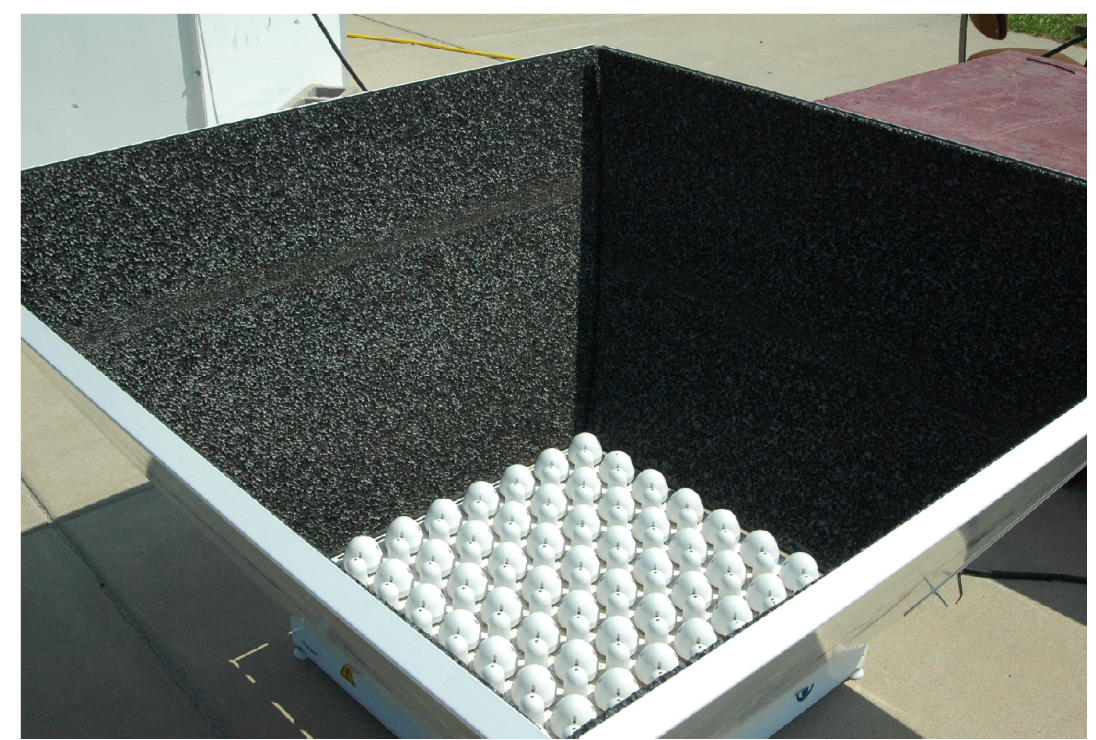

Figura A.2: Sodar Monoestático

O alcance vertical nominal do sodar pode variar entre 0,2 a $2 \mathrm{~km}$, dependendo do tipo de sodar utilizado e também de alguns parâmetros, como por exemplo: condições meteorológicas, estabilidade atmosférica, turbulência e principalmente pelo ruído do ambiente onde o sodar está sendo operado[3]. Neste trabalho foi utilizado um sodar MFAS do tipo monoestático, com detecção máxima de $1000 \mathrm{~m}$ de altura, porém a mesma foi limitada para $500 \mathrm{~m}$ afim de melhorar a resolução temporal e espacial. $\mathrm{O}$ mesmo foi operado pelo Prof ${ }^{\circ}$ Dr. Gerhard Held do IPMet-UNESP.

Os dados do sodar foram utilizados, juntamente com a análise visual, para caraterizar as diferentes situações meteorológicas descritas nos estudos de casos referentes a campanha de Vitória. Para isso utilizou-se os diagramas de PasquillGifford, o qual foi proposto inicialmente por Pasquill[35] como um método prático para a determinação da estabilidade atmosférica, incorporando os feitos atmosféricos da turbulência mecânica e turbulência térmica, mas posteriormente foi simplificada por Turner[50, 49], usando as taxas de radiação solar, cobertura de nuvem e velocidade de ventos, para aplicações em modelagem de dispersão de plumas.

Abaixo são mostrados os diagramas de Pasquill-Gifford para os dias da campanha de Vitória. Os mesmos são criados a partir do software APRu, sendo gerados com um intervalo de tempo de 30 minutos, porém é feita a média para um período de 60 minutos. 


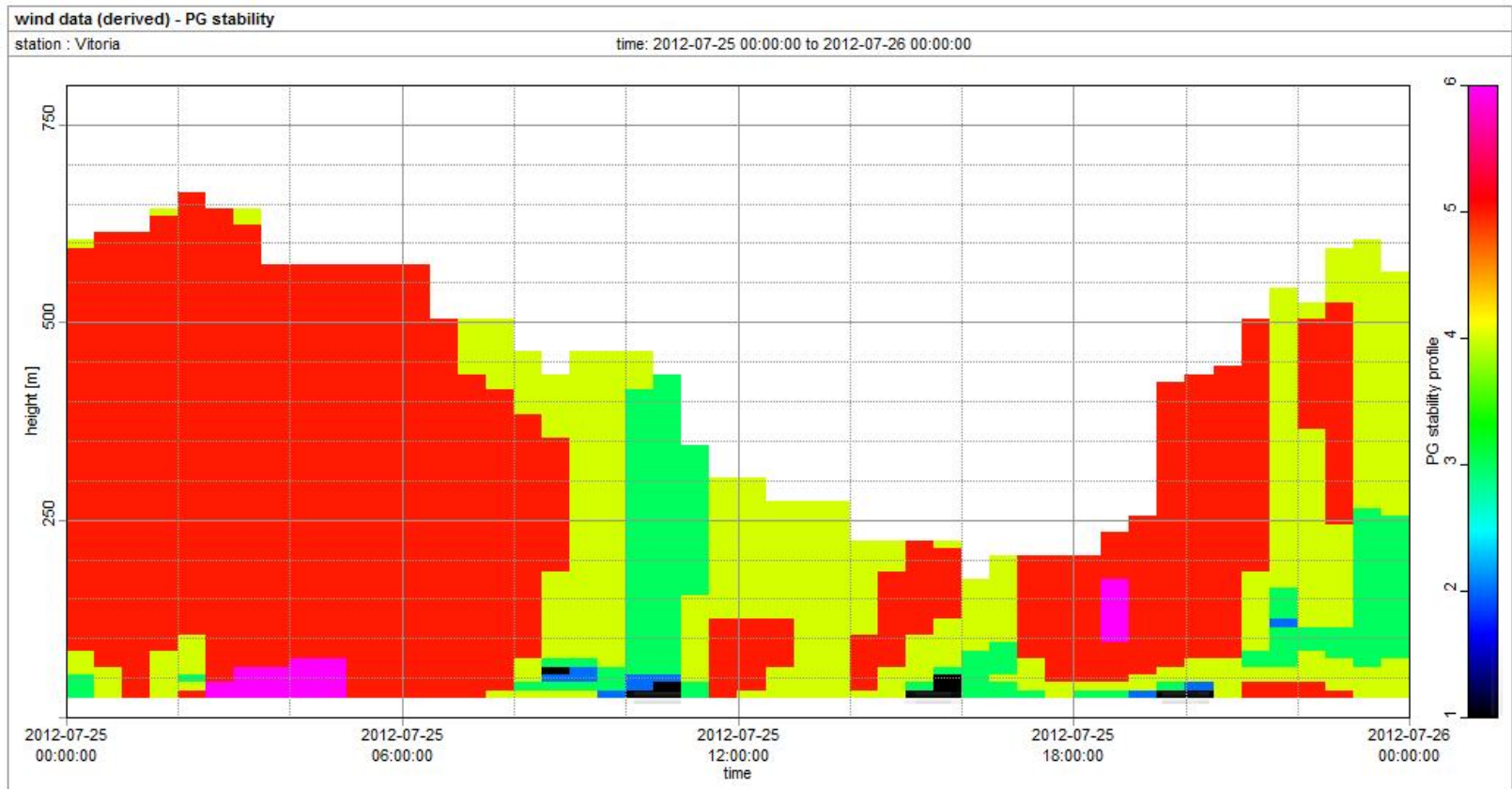

Figura A.3: Diagrama de Pasquill-Gifford para o dia 25 de julho.

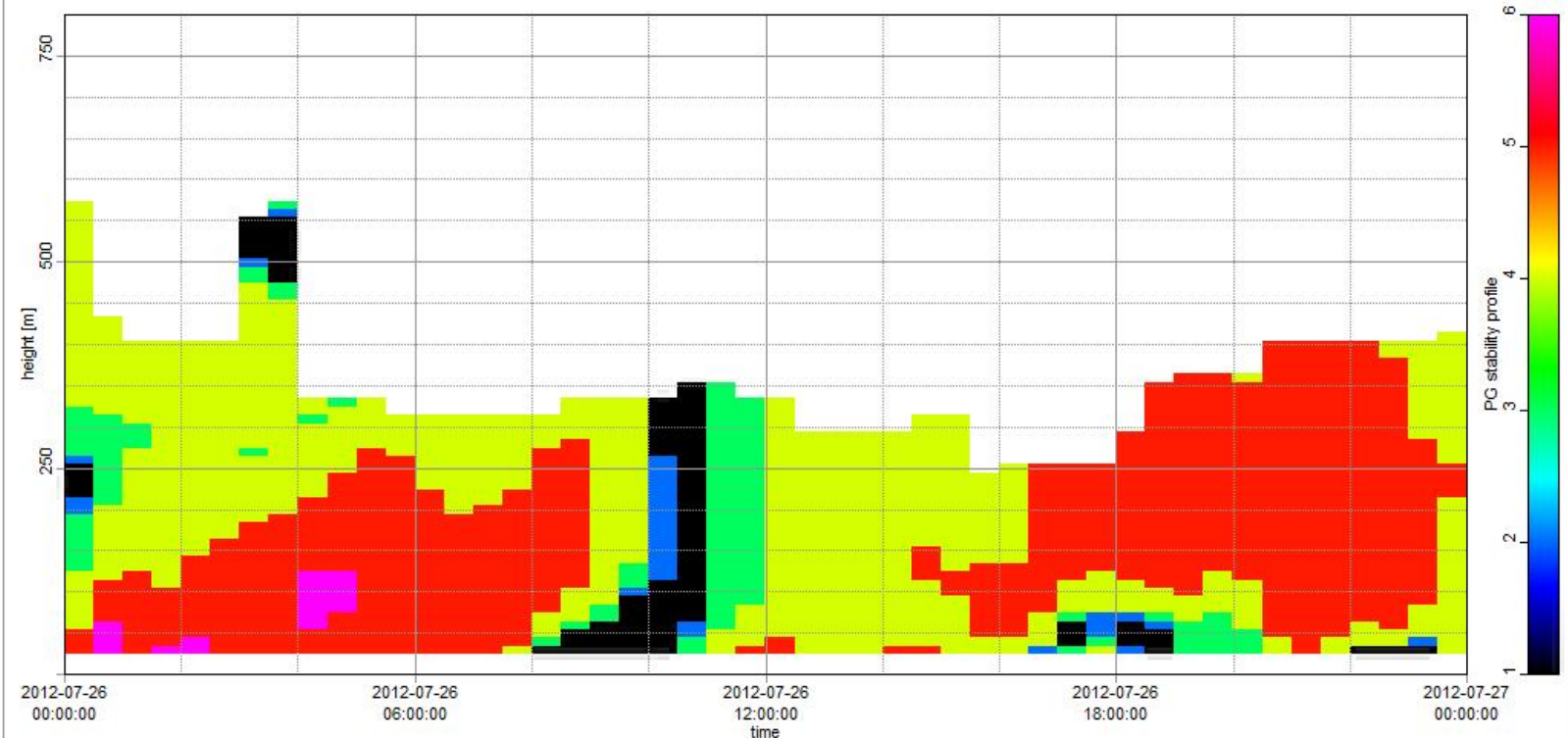

Figura A.4: Diagrama de Pasquill-Gifford para o dia 26 de julho. 


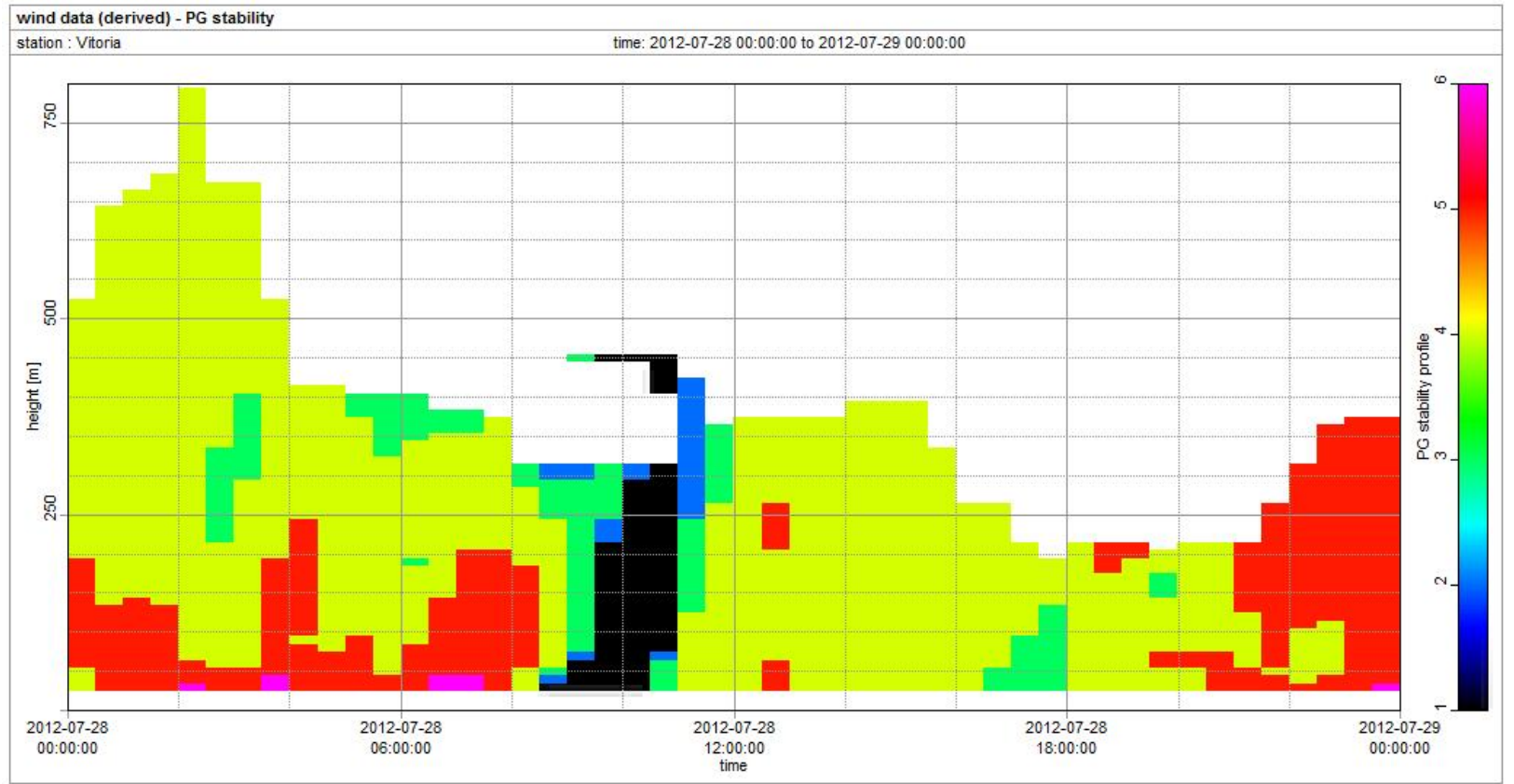

Figura A.5: Diagrama de Pasquill-Gifford para o dia 28 de julho. 


\section{Apêndice B}

\section{Estatística}

\section{B.1 Desvio Padrão}

Para uma melhor comparação entre os valores obtidos a partir dos métodos com os do BRN, foi calculado o desvio padrão da média $(s)$ :

$$
s=\sqrt{\frac{1}{n-1} \sum_{i=1}^{n}\left(x_{i}-\bar{x}\right)^{2}}
$$

onde $n$ é o número total de pontos obtidos a partir do método, $x_{i}$ o iésimo ponto $\mathrm{e}$ $\bar{x}$ o valor médio dentre os pontos fornecidos pelo método[6].

Como na maioria dos casos o BRN é representado por um único ponto, o cálculo do $s$ é capaz de representar quanto cada um dos pontos, obtidos através dos métodos, oscila em torno de um determinado valor médio, se afastando ou se aproximando do BRN.

\section{B.2 Média Móvel}

Devido aos métodos apresentarem muitas oscilações, foi utilizada a média móvel $M_{\text {movel }}$ para suavizar os perfis.

$$
M_{\text {movel }}=\frac{V_{1}+V_{2}+V_{3}+\ldots+V_{n}}{n}
$$


onde $V$ é o valor fornecido pelo método e $n$ é o número de pontos utilizados para fazer a média móvel[[]].

Desta forma foi possível reduzir o nível de ruídos e simplifcar o entedimento do comportamento de cada perfil. Foi adotado como critério fazer a $M_{\text {movel }}$ para um conjunto de $5 \%$ do número total de pontos, para não reduzir drasticamente a resolução temporal. 


\section{Referências Bibliográficas}

[1] ADDISON, P. S. Wavelet transforms and the ecg: A review. Physiological Measurement 26 (2005), 155 - 199.

[2] ARYA, S. P. Introduction to Micrometeorology. Academic Press, 2001.

[3] Atmospheric Research \& Technology, LLC. About Sodar, February 2008.

[4] BAARS, B. Continuous monitoring of the planetary-boundary-layer depth with lidar. Master's thesis, University of Leipzig, 2007.

[5] BAARS, H., ANSmanN, A., ENGElmanN, R., ANd Althausen, D. Continuous monitoring of the boundary-layer top with lidar. Atmospheric Chemistry and Physics 8 (2008), $7281-7296$.

[6] Bohm, G., ANd Zech, G. Introduction to Statistics and Data Analysis for Physicists. Verlag Deutsches Elektronen-Synchroton, 2010.

[7] BROOKS, I. M. Finding boundary layer top: Application of a wavelet covariance transform to lidar backscatter profiles. Journal of Atmospheric And Oceanic Technology 20 (2003), $1092-1105$.

[8] Buligon, L., Szinvelski, C. R. P., Acevedo, O., Gervásio A, D., And GoULART, A. G. O. Uma solução seminalítica para o perfil do vento médio na camada limite atmosférica: Parte ii. VI Workshop Brasileiro de Micrometeorologia, 2009. 
[9] Cheng, F. Y., Chin, S. C., AND LiU, T. H. The role of boundary layer schemes in meteorological and air quality simulations of the taiwan area. Atmospheric R 54 (2012), 714-727.

[10] COHN, S. A., AND ANGEVINE, W. M. Boundary layer height and entrainment zone thickness measured by lidars and wind-profiling radars. Journal of Applied Meteorology 39 (2000'), $1233-1247$.

[11] da Silva CorrêA, C., Vilhena, M. T., ANd Goulart, A. Uma solução analítica para a equação que descreve o decaimento da turbulência na camada limite convectiva: uma aproximação isotrópica. V Workshop Brasileiro de Meteorologia, 2007.

[12] DAVIS, K. J., GAMAGE, N., HAGELBERG, C. R., And KIELME, C. An objective method for deriving atmospheric structure from airbone lidar observations. Journal of Atmospheric And Oceanic Technology 17 (2000), 14551468.

[13] DE Oliveira, P. J., AND FISCH, G. Efeito da turbulênca na camada limite atmosférica em áreas de floresta e pastagem na amazônia. Revista Brasileira de Metereorologia 15 (2000), 39-44.

[14] DOS SANTOS, L. A. R., AND FISCH, G. Intercomparação entre quatro métodos de estimativa da altura da camada limite convectiva durante o experimento racci - Iba (2002) em rondônia amazônia. Revista Brasileira de Metereorologia 22 (2007), 322-328.

[15] EMEIS, S., SCHÄFER, K., AND MÜNKEL, C. Surface-based remote sensing of the mixing - layer height - a review. Meteorologische Zeitschrift 17 (2008), 621 -630 .

[16] Filho, E. P. M., Rizza, U., Karam, H. A., Carvalho, J. C., and Pereira, M. M. R. The stably-stratified pbl generated by les. V Workshop Brasileiro de Meteorologia, 2007. 
[17] Franchito, S. H., AND Yamazaki, Y. Um modelo simplificado de camada limite. Revista Brasileira de Metereorologia 1 (1986), 91-99.

[18] GAN, C.-M., WU, Y., MADHAVAN, B. L., GROSS, B., AND MOSHARY, F. Application of active optical sensors to probe the vertical structure of the urban boundary layer and assess anomalies in air quality model pm(2.5) forecasts. Atmospheric Environment 45 (2011), 6613 - 6621.

[19] GARRATT, J. R. The Atmospheric Boundary Layer. Cambridge University Press, 1992.

[20] GARRATT, J. R. Review: the atmospheric boundary layer. Earth-Science Reviews 37 (1994), $89-134$.

[21] Gomes, N., AND Ribeiro, J. Comparação entre a camada limite atmosférica oceânica e litorânea. V Workshop Brasileiro de Micrometeorologia, 2007.

[22] GRANADOS-MUÑOZ, M. J., NAVAS-GUZMÁN, F., BRAVO-ARANDA, J. A., GUERRERO-RASCADO, J. L., LYAMANI, H., FERNÁNDEZ-GÁLVEZ, J., AND ARBOLEDAS, L. A. Automatic determination of the planetary boundary layer height using lidar: One-year analysis over southeastern spain. Journal of Geop 117 (2012).

[23] GRAPS, A. An introduction to wavelets, 2003.

[24] HOLTON, J. R., PYLE, J., ANd CURRY, J. A. Enciclopedia of Atmospheric Sciences. Elsevier Science Ltd, 2002.

[25] IPCC, . Climate change 2007: Synthesis report. contribution of working groups i, ii and iii to the fourth assessment report of the intergovernmental panel on climate change [core writing team, pachauri, r.k and reisinger, a. (eds.)]. ipcc, geneva, switzerland, 104 pp., 2007.

[26] Kovalev, V. A., And Eichinger, W. E. Elastic LiDAR - Theory, Practice and Analysis Methods. John Wiley \& Sons, 2004. 
[27] LOPES, F. J. S. Estudo multi-instrumental das propriedades ópticas de aerossóis na cidade de São Paulo: Lidar elástico, Lidar Raman, Fotometria e Satélite CALIPSO. PhD thesis, Universidade de São Paulo, 2010.

[28] Marciotto, E. R., de Oliveira, A. P., and Ferreira, M. J. Estudo da clp urbana por meio de um modelo de fechamento de segunda ordem unidimensional. V Workshop Brasileiro de Micrometeorologia, 2007.

[29] Matos, C. A. D., TORRes, A. S., LANDUlfo, E., NAKAEMA, W. M., UEHARA, S. T., SAWAMURA, P., AND JESUS, W. D. Estudo de camada limite planetária com o uso de um lidar de retroespalhamento em são paulo, brazil. In Anais XIII Simpósio Brasileiro de Sensoriamento Remoto (2007).

[30] Measures, R. M. Laser Remote Sensing Fundamentals and Applications. Krieger Publishing Company, 1992.

[31] MENUT, L., FLAMANT, C., PELON, J., AND FLAMANT, P. H. Urban boundarylayer height determination from lidar measurements over the paris area. Applied Oprtics 38 (1999), $945-954$.

[32] Nunes, A. B. Crescimento da Camada Limite Convectiva: Estudo Analítico e Numérico. PhD thesis, INPE, 2008.

[33] OKE, T. R. Boundary Layer Climates. Taylor \& Francis e-Library, 2002.

[34] PAL, S., BEHRENDT, A., AND WULFMEYER, V. Elastic-backscatter-lidarbased characterization of the convective boundary layer and investigation of related statistics. In Annales Geophysicae (2010).

[35] PASQUILL, F. The estimation of the dispersion of windborne material. Meterolog. Mag 90 (1961), 33-49.

[36] Pleim, J., And Chang, J. S. A non-local closure model for vertical mixing in the convective boundary layer. Atmospheric E 26-A (1992), 965-968. 
[37] PLeim, J. E. A combined local and nonlocal closure model for the atmospheric boundary layer. part i: Model description and testing. Journal of Applied Meteorology and Climatology 46 (2007), 1383-1395.

[38] PLeim, J. E. A combined local and nonlocal closure model for the atmospheric boundary layer. part ii: Application and evaluation in a mesoscale meteorological model. Journal of Applied Meteorology and Climatology 46 (2007), 1396-1409.

[39] Rizza, U., Degrazia, G. A., Acevedo, O. C., and Goulart, A. G. Largeeddy simulation of the planetary boundary layer under baroclinic conditions during sunset turbulence. VII Workshop Brasileiro de Micrometeorologia, 2011.

[40] SEIBERT, P., BEYRICH, F., GRYNING, S.-E., JOFFRE, S., RASMUSSEN, A., AND TERCIER, P. Review and intercomparison of operational methods for the determination of the mixing height. Atmospheric Environment 34 (2000), 1001 $-1027$.

[41] SEIBERT, P., BEYRICH, F., GRYNING, S.-E., JOFFRE, S., RASMUSSEN, A., AND TERCIER, P. Chapter 20 - review and intercomparison of operational methods for the determination of the mixing height. In Air Pollution Science for the 21st Century (2002).

[42] SEIDEL, D. J., ZHANG, Y., BELJAARS, A., GOLAZ, J.-C., JACOBSON, A. R., AND MEDEIROS, B. Climatology of the planetay boundary layer over the continental united states and europe. Journal of Geophysical Research 117 (2012).

[43] Sinhori, N. P., Furtado, T. I., Reyes, I. N., Rizza, U., and Carvalho, J. C. A large-eddy simulation study of the stable pbl. V Workshop Brasileiro de Micrometeorologia.

[44] STEYN, D. G., BALDI, M., AND HOFF, R. M. The detection of mixed layer depth and entrainment zone thickness from lidar backscatter profiles. Journal of Atmospheric And Oceanic Technology 16 (1999), 953 - 959. 
[45] StuLL, R. B. An Introduction to Boundary Layer Meteorology. Kluwer Academic Publishers, 1988.

[46] SUGIYAMA, G., AND NASSTROM, J. S. Methods for determinig the height of the atmospheric boundary layer. Tech. rep., Lawrence Livermore National Laboratory, 1999.

[47] Talianu, C., NicolaE, D., CiUciU, J., CiobanU, M., and BABIN, V. Planetary boundary layer height detection from lidar measurements. Journal of Optoelectronics and Advanced Materials 8 (2006), 243 - 246.

[48] TOMASI, F. D., ANd PERRONE, M. R. Pbl and dust layer seasonal evolution by lidar and radiosounding measurements over a peninsular site. Atmospheric Research 80 (2006), 86 - 103.

[49] TURneR, D. Workbook of Atmospheric Dispersion Estimates. PHS Publication No 999-AP-26, U.S. Departmentoof Health, Education Welfare, National Air Pollution Control Administration, Cincinnati, Ohio., 1970.

[50] TuRneR, D. B. A diffusion model for an urban area. J. Appl. Meteor 3 (1964), 88-91.

[51] VICKERS, D., AND MAHRT, L. Evaluating formulations of stable boundary layer height. Journal of Applied Meteorology 43 (2004), 1736 - 1749.

[52] VILANI, M. T. Análise de Fourier e Wavelet em Variáveis Micrometeorológicas em Diferentes Tipologias de Ocupação. PhD thesis, Universidade Federal de Mato Grosso, 2011.

[53] WALLACE, J. M., AND HOBBS, P. V. Atmospheric Science - An Introductory Survey. Academic Press, 2006. 